\title{
PELAGE AND
}

\section{SURFACE TOPOGRAPHY OF THE}

\section{NORTHERN FUR SEAL}

\author{
By \\ Victor B. Scheffer \\ Biologist, Branch of Marine Mammals \\ BUREAU OF COMMERCIAL FISHERIES
}

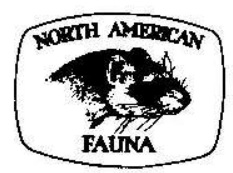

NUMBER 64 


\section{UNITED STATES \\ DEPARTMENT OF THE INTERIOR}

Stewart L. Udall, Secretary

FISH AND WILDLIFE SERVICE

Clarence F. Pautzke, Commissioner

BUREAU OF COMMERCIAL FISHERIES

Donald L. McKernan, Director

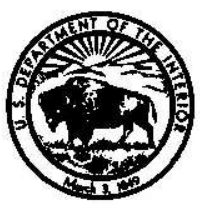

Nortb Americen Fanna, Nember 64

Published by U.S. Fish and Wildlife Service

February 1962 


\section{CONTENTS}

Abstract

Introduction

Previous research

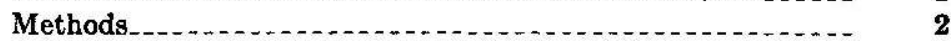

General structure of the body covering

Arrangement of the body layers.

The skin: epidermis, dermis, and sweat glands_........... 5

The pilosebaceous unit: follicle, root and shaft of the hair, and sebaceous glands.................. 7

The pelage

Fetal stages (sexes lumped)

Black pup, newborn (sexes lumped)

Synopsis of color pattern

Synopsis of pelage fibers.

Guard hairs: larger examples...................... 16

Guard hairs: smaller examples.................. 17

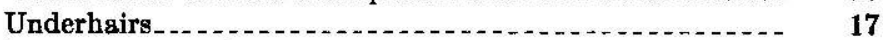

Black pup, molting (sexes lumped)

Silver pup (sexes lumped)

Synopsis of color pattern

Synopsis of pelage fibers.

Guard hairs: larger examples........................ 20

Guard hairs: smaller examples...................... 21

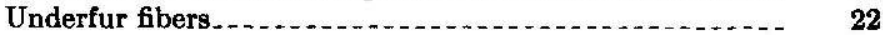

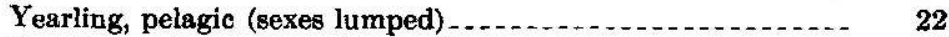

Yearling, autumn (sexes lumped)

Three-year-old, adolescent male (bachelor) ........... 23

Three-year-old, adolescent female (young cow)

Adult male (bull)

Adult female (old cow)

Variation in length of pelage fibers with age and sex........ 26

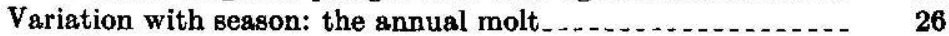

First molt. ...

Second molt.......... 27

Third molt

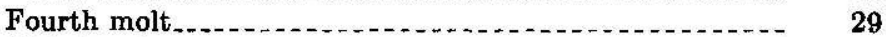

Molt in adults

Comparison with molt in other furbearers............. 31

The sensory vibrissae

Prenatal development of the vibrissae.

Postnatal development of the vibrissae.

Pelage anomalies.

Color anomalies_....... 35

Effect of diseases, parasites, and physiological disorders

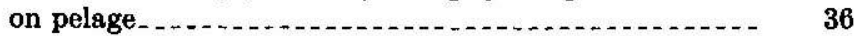

Effect of sex abnormalities on pelage _........... 39

Foreign growths_......... 39

The Pribilof sealskin industry

History of the industry

Killing, skinning, blubbering, and curing-....... 41

Processing and marketing-_-_....... 42 
The pelage-Continued

The Pribilof sealskin industry - Continued

Dimensions and weights of sealskins

Other features of the surface topography

Features of the head

Nostrils, mouth, and lips

Eyelids, eye glands, and iris

Ears

Features of the belly

Penial opening and scrotum

Female external genitalia.

Navel and tail

Features of the limbs_.._. 57

Flippers and claws.................. 57

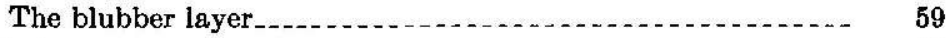

Summary .

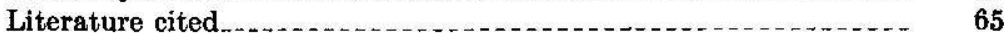

\section{TABLES}

Table 1. Length and weight of male fetal seals _.......... 71

2. Length and weight of female fetal seals ............. 71

3. Mean lengths of underfur and guard-hair fibers_...... 72

4. Length of longest vibrissa, by age and sex . . . . 72

5. Change in color of mystacial vibrissae, with age ...... 73

6. Sizes of grading boards for raw, salted skins

7. Sizes of male sealskins taken in early season _. . . . . . $\quad 73$

8. Sizes of male sealskins taken in late season

9. Weights of female seals, early and late summer...... 74

10. Weight of fresh, male sealskin with relation to field length of seal . . .

11. Trade classification of raw, salted, male sealskin with relation to field length of seal . ........

12. Trade classification of finished, dyed, male sealskin with relation to field length of seal . .................

13. Trade classification of raw, salted, male sealskin with relation to over-all dimensions

14. Trade classification of finished, male sealskin with relation to over-all dimensions

15. Length of ear from notch, by age and sex..........

16. Yield of oil from fur seals

\section{APPENDIXES}

Appendix A-Color notes

Silver pup, male

Silver pup, female

Yearling, autumn, male....... 84

Yearling, autumn, female

Three-year-old, adolescent male (bachelor)

Three-year-old, adolescent female (young cow) $\ldots \ldots \ldots \ldots$

Adult male (bull)

Adult female (old cow)

Appendix B-Glossary

\section{PLATES}




\section{ABSTRACT}

The midsummer population of northern fur seals, Callorhinus ursinus, is estimated at $1,978,000$. Of this number, $1,800,000$ or 91 percent, orig1nate on the Pribilof Islands. The Pribilof herd is capable of yielding 80,000 to 100,000 sealskins a year.

The pelage of the adult seal is composed of clearly defined bundles, each with a coarse guard hair and 35 to 40 fine underfur hairs; there are more than 300,000 fibers to the square inch. Each guard hair is accompanied by a sweat gland and two large sebaceous glands. Area of the haired surface of the body of the adult male is about 2.5 times that of the female.

The pelage of the pup resembles that of certain land carnivores in having small, scattered bundles, each containing 1 to 3 fibers, some of the fibers being underhairs and some overhairs (guard hairs). The first molt, from black birthcoat to silvery, adult-type molt, occurs about mid-September, the second in August of the following year (on the yearling), the third in September of the following year (on the 2-yearold), the fourth and subsequent molts in late September or October. The molt in the adult takes 4 or 5 months. Molting has little effect on the commercial value of a sealskin, provided the skin has been taken before September.

Dominant color of the adult pelage is light brownish gray; most seals are darker on back and chest, lighter on belly, throat, and sides. Color patterns of the sexes are indistinguishable up to age 2 or 3 years; color patterns of seals from American and Asian waters are indistinguishable. Colors are brighter (less brownish) in winter when the seal is at sea and has completed its autumnal molt.

In addition to mutant color phases such as albino, piebald, and chocolate, one may see atrichia, pediculosis, pachyderma, and other skin disorders; and foreign growths, including marine algae and barnacles, on the guard hair.

The flippers are naked. The only functional claws--used exclusively for grooming the pelage-are on the middle three digits of each hind flipper. The blubber on the fur seal is thinner than on phocids or hair seals. From a fur seal weighing 66 pounds about 0.6 gallons of blubber oil can be rendered. 


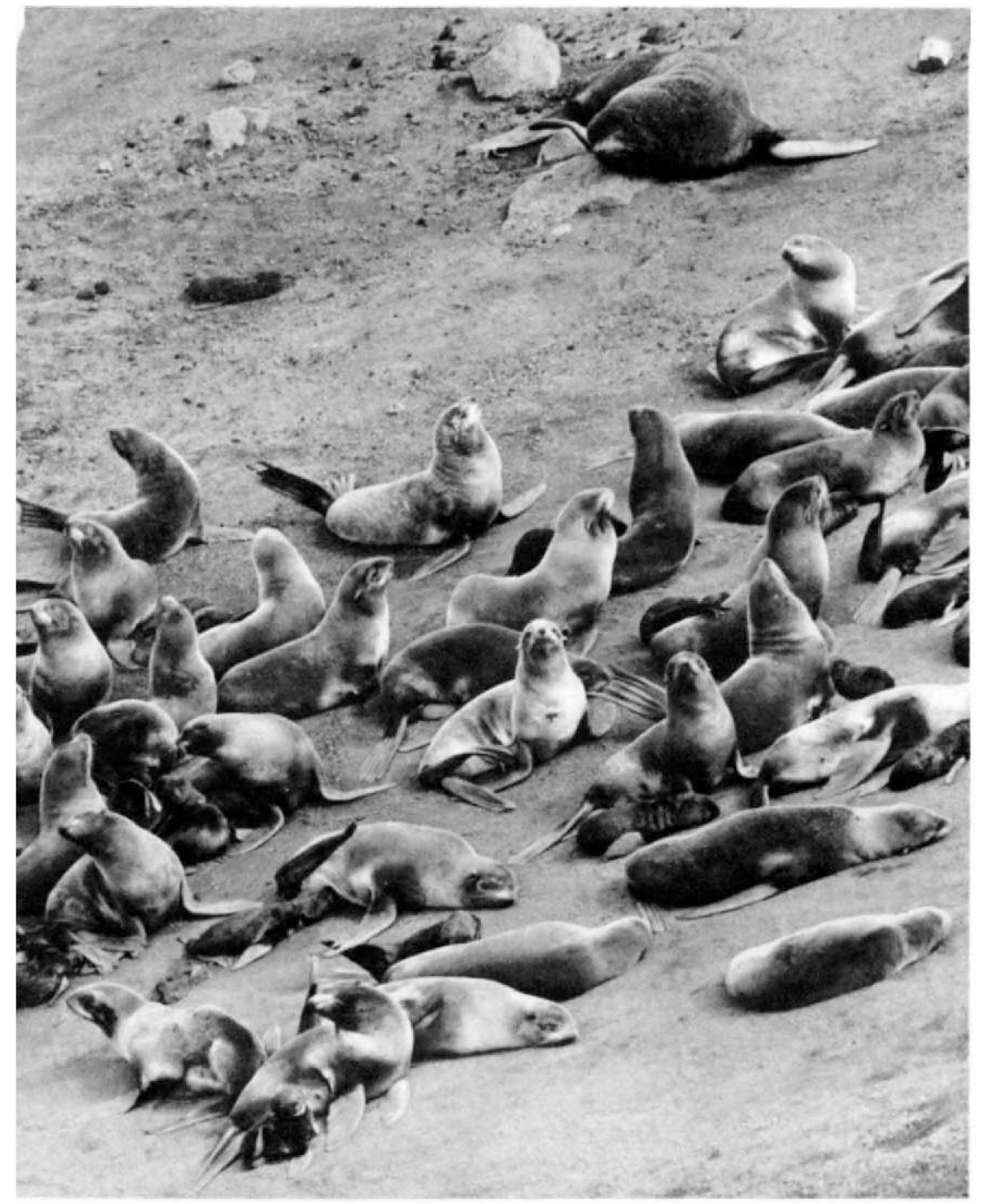

FrontrsPrEcE-Fur seals on breeding grounds, 5 July, shortly before height of pupping season. Harem bull in background; cows and newborn pups in foreground. Adults are in old pelage, about ready to molt. 


\section{INTRODUCTION}

The northern fur seal, Callorhinus ursinus (L.), breeds on islands of the North Pacific Ocean and adjacent seas. The midsummer, or maximum seasonal, population is estimated at 1,978,000 animals; of this number, about $1,800,000$, or 91 percent, originate on the Pribilof Islands of Alaska. Since 1867 the United States Government has acted as custodian of the Pribilof herd and has regulated the taking of sealskins for market. In 1958 the Pribilof herd produced 78,919 skins. It is quite certainly capable of producing 80,000 to 100,000 skins a year, the quantity depending partly on man's selection (by age and sex) of the animals to be cropped and partly on natural fluctuation in birth rate and mortality of seals.

During its 90-year regime, the Government has sought increasingly to understand the zoology of the fur seal, the better to manage the seal population as a national and international resource. However, with regard to the fur-seal pelage - the basis of production-no sustained effort to obtain zoological information was made until recent years. In 1940, Government biologists concerned with management research on the seal herd began to collect specimens and field notes, looking toward a report on the growth and replacement of pelage fibers. The present paper describes certain gross and microscopic aspects of the pelage in relation to sex, age, and season of year. It also describes, in a cursory way, other features of the surface topog. raphy such as flippers, ears, tail, blubber, and mammary glands. These features of pinniped anatomy are seldom preserved for study, and when they are preserved they tend to lose their original shape and color. It has seemed desirable, therefore, to describe and illustrate certain appendages, soft parts, and subdermal layers of the body covering in their natural condition. The scope of the present work is indicated by the table of contents.

For advice in my research, I am grateful to many persons; I would mention especially Ford Wilke, Chief, Marine Mammal Research, Bureau of Commercial Fisheries, and Dr. George F. Odland, Clinical Instructor, University of Washington Department of Anatomy.

\section{Previous Research}

World literature on the subject of mammalian hair, especially the hair of man, domestic animals, and wild furbearers, is voluminous. On the structure, growth, and replacement of fur-seal pelage fibers, 
however, no scientific literature exists, partly because fur seals do not inhabit North Atlantic waters and have not been available to European zoologists for study. There are, to be sure, a number of fleeting references to fur-seal pelage and many popular and scientific accounts of the general biology of the seal. It may be helpful at this point to list the more important papers that have contributed a background to our understanding of fur-seal pelage. These papers will be referred to later and individually, and will be described more fully under Literature Cited :

Abegglen and others (1956-58), progress reports of investigations on the Pribilof Islands; Baker (1957), general account of Pribilof industry ; Bartholomew (1951), observations of living seals; Bartholomew and Hoel (1953), breeding habits; Bowker (1931), leather; Clegg (1951), blubber; Fortune (1930), sealskins ; Fouke (1949), sealskins; Fouke Fur Company (1958), popular account of sealskin industry ; Fur Trade Review (1916), sealskins; Jordan and others (1898), comprehensive account; Mathur (1927), leather; Minato (1949), blubber; Miyauchi and Sanford (1947), blubber; Partridge (1938), leather; Pearson and Enders (1951), reproduction; Rand (1956), general biology of the South African fur seal Arctocephalus pusillus; Scheffer (1949 and later), various reports touching on pelage and blubber; Scheffer and Kenyon (1952), general account; Scheffer and Wilke (1953), growth data; Stevenson (1904), sealskins; Stoves (1958), northern and southern fur seals Callorhinus and Arctocephalus; Taylor and others (1955), comparisons of Asian and American fur seals; Terao (1940), leather; Thompson (1950), general account of Pribilof industry; U.S. Bureau of Fisheries (1916, 1917, 1922, 1938), sealskins and blubber; U.S. Fish and Wildlife Service (1952-57), sealskins and blubber; Wilber (1952), lreak blubber.

\section{Methods}

Specimens were collected on the Pribilof Islands, at sea off the American coast between California and Alaska, and at sea off Japan. Land specimens were taken in summer and fall, pelagic specimens in spring and summer, all between 1940 and 1959. Up to about 1949, the age of an individual seal was estimated from body size; thereafter from tooth-ridge counts (Scheffer, 1950 a). It was determined directly when the seal happened to be wearing a metal tag (Scheffer, $1950 \mathrm{~b}$ ). Government biologists have tested various methods of marking individual seals for study purposes. The accepted method, now being applied to 50,000 seals a year, is to fasten a corrosion-proof, individually numbered metal tag to one of the flippers of the pup. In the past, as many as 10,000 seals a year were marked by a hot-iron brand which left a rectangular patch of the skin permanently denuded. Quick-drying, synthetic-base "traffic" type paint in yellow, blue, or white, applied with a swab, has been used to mark individuals temporarily in summer. Chemical depilatories have proved to be of no practical value, since they penetrate with great difficulty the dense, 2-layered pelt of the seal. 
Forty fetuses were examined, of which 25 were selected as showing critical features of growth. About 200 pelts, mostly of known-age seals, were preserved by tanning and were later studied in the National Museum collection. Photographs (mostly at scale 1/16) were taken of 149 of these pelts, and hair measurments were made of 114. In September 1958, on St. Paul Island, I made a special collection of bits of skin, in formalin, from neck, back, and belly of 76 seals of assorted age and sex.

More than a million seals have been killed commercially on the Pribilof Islands since 1940, and their pelts have provided clues not only to the procession of molt in autumn but also to the incidence of freaks and diseased individuals in the population as a whole.

On several occasions, starting in 1952, fur seals were brought from St. Paul Island to the Seattle Zoo. Here they were held in a large, outdoor, fresh-water pool and were subjected to shearing experiments. Observations were subsequently made of the rate of regrowth of underfur and guard hair. (For one reason or another, the schedule of observations was often interrupted.) The total number of seals marked by shearing was eight.

With the exception of color notes recorded in the field, studies of pelage were carried out in the Seattle office of Marine Mammal Research. As will be explained, the Munsell system of color notation was used. Under the direction of Dr. George F. Odland, median sections of skin, stained with haemotoxylin and eosin, were prepared by $\mathrm{Mr}$. James Rankin. Slides of horizontal sections were prepared by technicians of the General Biological Supply House. At one time or another, certain devices and techniques described by the following hair specialists were used for the present study :

Carter (1939), horizontal sections and follicle populations; J. I. Hardy (1935), cross sections of hairs by special tool; Hardy and Plitt (1940), casts of cuticular scales in plastic media; Mathiak (1938), cross sections of hairs by razor blade; Stoves (1958), many aspects of fiber microscopy ; Wildman (1954), many aspects of fiber microscopy. 



\section{GENERAL STRUCTURE OF THE BODY COVERING}

\section{Arrangement of the Body Layers}

The layers of the body covering of the fur seal, from the outside in, are (1) the hairy coat or pelage, (2) the skin proper (the leather of the tanned pelt), (3) the panniculus adiposus or blubber, (4) the panniculus carnosus or discontinuous, fleshy sheet of muscle beneath the blubber, and (5) the tela subcutanea or loose, thin, whitish, connective tissue which binds the skin to the muscles and bones of the body. The layers are shown in plates 2-8. ${ }^{1}$ (Leather technologists commonly use the term "epidermal area" in a collective sense for all the strata down to and including the sweat glands, and the term "corium" for the deeper, fibrous strata. Roddy (1956), for example, has observed that in most commercial fur skins there is no marked distinction between "epidermal area" and "corium.")

The area of the haired surface of the body (that is, the surface exclusive of flippers) has been measured on two tanned pelts, as follows: Adult male, length of pelt $199 \mathrm{~cm}$., area $1.57 \mathrm{sq}$. m. Adult female, length of pelt $119 \mathrm{~cm}$., area $0.62 \mathrm{sq} . \mathrm{m}$. In this sample, the male pelt has an area 2.5 times that of the female. Scheffer and Wilke (1953, p. 145) had previously concluded that the adult male outweighs the female about 4.5 times.

To the student of pelage, the two most interesting parts of the body covering are the skin proper (epidermis, dermis, and sweat glands) and the pilosebaceous unit (follicle, root and shaft of the hair, and sebaceous glands). I shall discuss first the skin and second its outgrowth-the hair. (For definitions of technical terms, the reader is referred to the glossary in appendix B, or to medical dictionaries.)

\section{The Skin: Epidermis, Dermis, and Sweat Glands}

Sections of skin from the back region of two 7-year-olds have been studied in detail (plates 9 and 10). The epidermis is not over 60 microns thick, much thinner than the epidermis of the harbor seal, reported by Montagna and Harrison (1957, p. 83) as 0.5 to 1 millimeter thick over the entire body. In the fur-seal epidermis, the

\footnotetext{
1 Plates follow page 93.
} 
stratum corneum is about 15 microns thick, appearing in 4 to 8 layers, more or less shattered, on prepared slides. It is sharply distinct from the underlying stratum malpighii which is 18 to 35 microns thick. The stratum malpighii consists of a superficial layer 1 to 3 cells deep in which a stratum granulosum and a stratum spinosum cannot be distinguished, and a stratum germinativum 1 cell thick. The cells of the stratum germinativum are more or less columnar, deeply staining; those of the superficial layer are cuboidal or flattened, faintly staining.

In life, the dermis is 3 to $4 \mathrm{~mm}$. thick. While the dermis, in general, is thicker in adult animals than in young, and in males than in females, its follicular (hair root) portion does not vary appreciably in thickness. On 12 slides selected as showing true median sections with minimum distortion, there is surprisingly little difference in depth from surface of skin to base of deepest hair follicle, measured at right angle to surface of skin. In a group of 2-year males, 2-year females, over-10-year females, and one old bull, the range in thickness (depth) was 2.0 to $2.8 \mathrm{~mm}$., with an average between 2.3 and 2.4 'Tanned and buffed as "Alaska sealskin," the leather of a subadult male is less than $1 \mathrm{~mm}$. thick; tanned as saddle leather, the skin of a bull seal is about $4 \mathrm{~mm}$. thick.

An apocrine sweat gland is associated with each guard-hair follicle (plate 11). The gland is sinuous and unbranched. A true median section may expose 50 of its loops. The secretory portion of the gland originates deep in the dermis, beneath, and to the rear of, the guardhair root. It may start at the 3-mm. level (depth), though more often above $2.2 \mathrm{~mm}$. The secretory portion is 1 cell thick. The gland is largest at about the 1.4- $\mathrm{mm}$. level, where a cross section may measure 80 by 120 microns; it begins to disappear at levels between 1.0 and $0.8 \mathrm{~mm}$. Here it is replaced by the more superficial massed bulbs of the underfur follicles. The duct of the sweat gland is several cells in thickness and represents about one-quarter of the vertical depth of the gland, though. much less than one-quarter of the entire sinuous length of the gland. The duct rises through the common follicular bundle at the right or left side, more or less between the guard hair and the underfur fibers. It empties into the pilosebaceous funnel at the surface of the skin, above the twin exits of the sebaceons glands. Near the surface, the sweat-gland duct has a lumen 10 to 15 microns wide. Here the duct is invested in a heavy epidermal sheath.

Early sweat glands, nebulous and more deeply staining than mature ones-certainly not functional-can be seen at levels between $1.2 \mathrm{~mm}$. and $1.6 \mathrm{~mm}$. below the surface of the skin of the back of the neck of a full-term fetus. The sweat glands of a molting black pup, on 1 September, are adult in character. 
When a heat lamp is focused on the naked flipper of a freshly killed seal, the black epidermis soon begins to blister. Before it does so, droplets appear on the surface of the skin in a fairly regular pattern (plate 12). These are assumed to be secretions of the sweat glands.

The survival value of sweat glands beneath the dense pelage of the fur seal is not clear. Aoki and Wada (1951, p. 123) confirmed that sweat glands are present in the dog, not only in the foot pads but also over the body surface covered by hair. Those authors induced sweating both by drugs and by radiant heat. They concluded "that the sweat glands in the hairy skin of the dog do not participate actively in the central thermoregulatory mechanism, but ... subserve chiefly the protection of the skin from an excessive rise of temperature."

\section{The Pilosebaceous Unit: Follicle, Root and Shaft of the Hair, and Sebaceous Glands}

Details of the main body pelage and vibrissae will be given in the next chapter. The present account is intended to provide background information (plates 13-31). The pelage of the fur seal is made up of bundles or tufts of hairs emerging from the surface of the skin through a common pilosebaceous funnel and orifice. The hairs are flattened and are generally directed hindward and downward, thus contributing to the sleek, streamlined profile of the body. Each hair, of course, originates in its own follicle. The anteriormost (uppermost) hair in each follicular bundle is a coarse guard hair, deeply rooted. Next in rank are 35 to 40 fur fibers arranged in stairstep fashion, the root of the fiber at the rear of the bundle being nearest the surface of the skin. The fur hairs originate separately, converge tightly at the level of the upper dermis, and diverge outside the body. They rise from the skin at a slope of $40^{\circ}$ to $50^{\circ}$ from horizontal. The number of follicular bundles per sq. $\mathrm{mm}$. on skin from the back of adults has been estimated at 11 (on suede leather, plate 6), at 17 (on another sample of suede leather), and at 15 (on a horizontalsection slide, plate 13). Selecting 15 as a reasonable average and using 38 fibers per bundle as a factor, it is calculated that there are about 570 fibers per sq. mm., or 370,000 fibers per sq. in.

The hair follicle is considered by most anatomists to be an invagination of the epidermis. One can trace the stratum corneum and stratum malpighii deep into the follicle, almost to its base. At the follicalar level, the epidermis becomes the outer root sheath. An inner root sheath clings for a short distance up the hair root. A connective tissue 
papilla enters the bulb of the root, while surrounding the papilla are the matrix cells or germinative cells of the hair.

The hair consists of a swollen basal bulb and a shaft. The bulb and other buried regions of the hair are termed, collectively, the root. The shaft is free and is largely outside the body. Listed in order from the central axis outward, the shaft consists of a vacuolated medulla (absent in fine hairs), cortex (usually pigmented), and cuticle (made up of overlapping scales). I have been unable to demonstrate arrectores pilorum, or hair-erecting muscles, in the skin of the seal. Bergersen (1931, p. 170) could find none in the skin of the harp seal Pagophilus.

The paired sebaceous glands lie along the sides of, and within, the common follicular bundle. They attend the guard hair, not the fur hairs, although their secretion is shared by all members of the bundle. Each gland originates at about the level of the underfur bulbs, or 1.0 to $0.8 \mathrm{~mm}$. below the surface. The deeper portion of the gland is subdivided into 2 or 3 shallow, roundish, irregular lobes. The upper portion is a rather smooth dome. At the level of greatest size, 0.6 to 0.4 $\mathrm{mm}$. deep, the gland may measure 90 by 150 microns. Each gland pours its secretion from the top directly against the right or left posterior side of the guard hair, at about the $0.2-\mathrm{mm}$. level. The lumen of the duct is 15 to 25 microns wide.

In a full-term fetus, the sebaceous glands are well developed, up to 40 by 70 microns in horizontal section, and apparently are functional. Most of them are above the $0.5-\mathrm{mm}$. level. 


\section{THE PELAGE}

The principal aims of this chapter are to describe the gross, as well as the microscopic, aspects of the pelage on representative specimens ranging in age from fetal to old adult. Since the fur seal exhibits only two distinct kinds of pelage - the black birthcoat and the silver adult-type coat--emphasis is placed on descriptions of the black pup and the silver pup. Color pattern is discussed synoptically; additional notes are given in appendix A. Because they represent specialized, nonmolting hairs, the sensory vibrissae are discussed last. The naked, or nearly naked, parts of the body surface are discussed in the next chapter.

To illustrate changes in the pelage during prenatal life, descriptions of the hair primordia and hair fibers on 25 selected fetuses are given. To illustrate changes in the pelage during postnatal life, descriptions of typical individuals in each of the following classes are given (where no sex distinctions can be seen, male and female are treated as one) :

\section{Pelage class \\ Approasmate duration of this pelage}

black pup, newborn (sexes lumped) black pup, molting (sexes lumped) 2 weeks (e.g., 15-31 July).

2 months (e.g., 1 August-30 September).

silver pup, persisting as yearling, pelagic 11 months (e.g., 1 October-31 Au(sexes lumped).

yearling, autumn (sexes lumped) gust).

3-year-old, adolescent male (bachelor) 13 months (e.g., 1 September-30 September.)

1 year (e.g., 1 October-30 September).

3-year-old, adolescent female (young cow) -- 1 year.

adult male (bull)

adult female (old cow)

In tracing the development of the pelage, I have usually omitted reference to body size since growth tables have already been published by Scheffer and Wilke (1953) and Scheffer (1955). An exception is made in the case of fetal specimens. It has seemed useful to give the weight of each fetus, since clearly the prenatal age of the specimen from implantation cannot be known. The mean date of implantation is quite certainly in early November, a date that I have chosen from study of the figures in tables 1 and 2. These tables show length and weight of 366 fetal seals collected at sea between mid- 
January and the end of June. Dr. D. G. Chapman (personal correspondence) has estimated that, as of 21 November of the preceding year, the average fetus would have measured: male, $5.4 \mathrm{~cm}$. and $10 \mathrm{~g}$.; female, $5.1 \mathrm{~cm}$. and $10 \mathrm{~g}$.

It has seemed useful to give also the relative weight of the fetus, or its weight in relation to normal size at birth. Scheffer and Wilke $(1953$, p. 133,135$)$ measured 39 newborn seals and reported certain values. (See bottom row in tables 1 and $2^{2}$ of the present report.) These values for mean newborn weight are used as reference points in describing the stage of development of the fetus. For example, a male fetus of $2.7 \mathrm{~kg}$. is described as " $0.50 \mathrm{MNW}$ ", or one-half mean newborn weight.

\section{Fetal Stages (Sexes Lumped)}

Early stages, between the autumn blastocyst (a pearly sphere barely visible to the naked eye) and the midwinter fetus (the size of a man's thumb) are unknown. The height of the mating season is in July. Three to four months later, the fertilized egg has become the blastula, at which time it implants in the uterine mucosa (Pearson and Enders, 1951). As just stated, the estimated date of implantation is early November.

\section{Fetus of $23.7 \mathrm{~g}$. (0.0049 MNW), female, 14 February}

This is the smallest fetus available for study (plate 32-A). Most of the body is smooth. On forehead and crown there is faint but distinct and regular pimpling. Each pimple marks the site of a hair primordium beneath the skin surface. With a $5 \times$ hand lens one can see, through the translucent epidermis, a dark dot in each pimple. This dot represents a concentration of melanocytes. A regular pattern of dark dots extends along the back, though pimpling of the surface has not begun here. Elsewhere than on head and back, faint white dots, visible through the epidermis, mark the sites of primordia in which the elaboration of pigment has not begun. Collectively, the dots on the head impart a gray cast; the rest of the body is whitish. The primordia resemble those in the skin of a 5-month-old human embryo (compare Montagna, 1956, p. 180, fig. 5).

\section{Fetus of $103 \mathrm{~g}$. (0.021 MNW), female, 20 January}

The skin over the entire body, except flippers and other parts destined to remain naked, is pimpled. No body hairs have erupted. Pigmentation is beginning to show on the flippers in the form of extremely fine, scattered, dark specks. It is heaviest at the base of each fore and hind claw. It is barely visible on the nostrils.

\footnotetext{
2 Tables will be found at pages 71-79.
} 


\section{Fetus of $131 \mathrm{~g}$. (0.024 MNW), male, 25 January}

The forehead, crown, and eyelids are distinctly washed with gray. The nostrils are conspicuously gray. No hairs have erupted.

\section{Fetus of $260 \mathrm{~g}$. (0.054 MNW), female, 19 January}

Extremely fine black hairs have appeared on the face, top of snout, around the eyes, and under the chin (plates 34 and 35). This first pelage could easily be overlooked if one were not looking for it. The hairs on the cheek posterior to the mystacial vibrissae are the longest; those under the chin, the smallest. No external hairs can be seen on back, tail, or other parts of the body.

The largest hairs are flattened, $1.5 \mathrm{~mm}$. in length, about 12 microns wide along most of the shaft, up to 50 microns in diameter at the flared base, heavily pigmented. These are the young, distal portions of black-pup guard hairs.

\section{Fetus of 312 g. (0.058 MNW), male, 6 February}

A few tiny hairs have erupted on the cheeks and above the eyes; the rest of the body is naked.

\section{Fetus of $372 \mathrm{~g}$. (0.077 MNW), female, 16 February}

This fetus was removed from an adult taken at sea and subsequently held in cold storage for 8 days (plate 36). On a photograph of the fetus in storage, the head and flippers appear darker than the rest of the body. This seems to represent the beginning of conspicuous pigmentation, although it may be, instead, dark blood beneath the thinner-skinned parts of the body.

\section{Fetus of 454 g. (0.084 MNW), male, 15 February}

A few hairs on the cheeks only.

\section{Fetus of 575 g. (0.11 MNW), male, 13 February}

At first glance, a naked fetus, though close inspection reveals fine hairs over most of head and throat. The head and flippers are definitely darker than the rest of the body.

A horizontal section from the back of the neck of this fetus is shown in plate 37. It exhibits a regular pattern of hair follicles, about 10 per sq. mm., each with a faintly pigmented hair. Some follicles reach a depth of $0.5 \mathrm{~mm}$. Scattered among them, and outnumbering them 10 to 20 times (depending upon how the count is made), are small, dark primordia without hairs.

The hairs in their present stage of development cannot be identified as the tips either of guard hairs or underhairs. Some may, in fact, be lanugo hairs destined to be shed before the birthcoat is complete, 4 to 5 months hence. Quite certainly each marks the site of a perma- 
nent follicular bundle. And certainly additional bundles will appear, since the bundles of the birthcoat are four times more abundant than are the hair follicles of the present fetus. (Compare plates 37 and 46.)

The small, dark primordia shown in the fetus of plate 37 are distributed singly or in clusters of 1 to 4 . When in clusters, they are aligned with the long axis of the body, the anterior primordium being the largest. I do not know what these primordia represent. They are most likely very early stages of the birthcoat underhairs, or sebaceous glands (which will appear in the birthcoat), or a combination of the two.

\section{Fetus of $580 \mathrm{~g}$. (0.11 MNW), male, 31 May}

This individual may have implanted very late in spring for, though taken in late May, it resembles a February fetus. Vellus over entire body, except palmar and plantar surfaces of flippers; well developed only on head. The heaviest pelage is on each cheek posterior to the mystacial vibrissae. Here the effect is of a smoky gray wash on the side of the face. The blacker, heavier hairs are young guard hairs up to 40 microns wide at the base, distinctly medullated. The vellus fibers are young underhairs.

Fetus of 595 g. (0.12 MNW), female, 6 February

Hairs barely visible over body; head well haired.

Fetus of 660 g. (0.14 MNW), female, 15 February

Hairs over entire body (plate 38-A).

Fetus of $1.09 \mathrm{~kg}$. (0.20 MNW), male, 25 March

Vellus has appeared on ear tips, giving a grayish cast.

Fetus of $1.19 \mathrm{~kg}$. (0.22 MNW), male, 30 March

The pelage of the head has extended to the extreme tip of the snout. On the upper surface of the fore flipper, one can clearly distinguish the haired (proximal) and nearly naked (distal) surfaces. A $5 \times$ lens, however, reveals fine vestigial hairing over the distal portion, destined in the adult animal to become naked. The bases of the mystacial vibrissae are hidden in the dense pelage of the face.

\section{Fetus of $1.11 \mathrm{~kg}$. (0.23 MNW), female, 23 March}

The ears are well haired and gray along their full length. The blades of the guard hairs, which contribute virtually all of the blackness of the birthcoat, are now emerging from a background of young, whitish underhairs. On the palmar and plantar surfaces of the flippers, especially near their edges, one can discern a few fine hairs, destined to disappear at birth. 
Fetus of $1.23 \mathrm{~kg}$. (0.23 MNW), male, 27 March

The ears are thinly haired, whereas on a smaller specimen the ears are thickly haired.

Fetus of $1.42 \mathrm{~kg}$. (0.26 MNW), male, 22 March

The only conspicuous pelage is that of the crown and face.

\section{Fetus of $1.45 \mathrm{~kg}$. (0.27 MNW), male, 11 August}

Prematurely born, found dead on St. Paul Island. The face, crown, and ears are very dark gray. The upper surface of the fore flipper is covered with distinct vellus, most of which will be retained up to the normal time of birth.

\section{Fetus of $1.45 \mathrm{~kg}$. ( $0.27 \mathrm{MNW})$, male, 25 March}

Although of same weight as the preceding one, this fetus is $39 \mathrm{~cm}$. in length as against $37 \mathrm{~cm}$. (plate 39 ). A faint gray streak has appeared along the back and around the base of the tail, marking the first appearance of regularly spaced, coarse, dark guard hairs.

\section{Fetus of $1.70 \mathrm{~kg}$. (0.35 MNW), female, 12 April}

The dark streak has spread along the back and rump. Growth has been backward from the head and forward from the tail, leaving an area on the back where the streak is less prominent. The face is now handsomely marked with dark and light zones (plate 41-A).

Fetus of $1.93 \mathrm{~kg}$. (0.36 MNW), male, 2 April

Generally speaking, the fetus is gray (plate 38-B). The head and base of tail are dark gray. The pattern of dark guard hairs against lighter underhairs, giving the effect of a dark wash, has spread downward from the back to the flanks.

Fetus of $2.21 \mathrm{~kg}$. (0.41 MNW), male, 2 May

The dark effect caused by coarse guard hairs has spread to the under part of the body only at chin and throat (plate 40). The pelage has been slowest to develop on the posterior region of the chest, between the fore flippers. A few white-tipped guard hairs show on the cheeks and sides of the head, behind the ears. Whereas many mammals are marked with a dark streak along the back, the fur seal exhibits a dark streak for a short time only, while the fetal guard hairs are erupting.

\section{Fetus of $2.27 \mathrm{~kg}$. (0.47 MNW), female, 21 April}

The dark guard hairs are approaching the chest.

\section{Fetus of $2.72 \mathrm{~kg}$. (0.50 MNW), male, 21 April}

A fur seal delivered on the the breeding ground at this stage would probably survive. (An aborted fetus of $1.59 \mathrm{~kg}$, was seen alive on 16 
July and was picked up dead on the following day.) At first glance, the fetus would be called black. The black guard hairs are now distributed over the entire body, though thinly on the chest, which remains light colored. White hairs surrounded the penial opening, especially its posterior margin.

Fetus of $2.44 \mathrm{~kg}$. (0.51 MNW), female, 21 April

A transverse zone of gray persists on the posterior part of the chest, between the flippers (plate 42). Coarse, black guard hairs are showing for the first time here, starting along the midventral line.

Fetus of $3.43 \mathrm{~kg}$. (0.71 MNW), female, one of twins, 9 May

All black, well haired, with a sprinkling of white hairs on sides of neck and throat, on posterior part of belly, and in armpits (plate 43). Vellus persists on the dorsal surface of the fore flipper.

\section{Black Pup, Newborn (Sexes Lumped)}

\section{SYNOPSIS OF COLOR PATTERN}

At first glance, the pup appears to be all black (plate 44). Above, the coat is glossy black with a few scattered white hairs on forehead and on neck behind ears. Corners of mouth may be stained brownish by bile. Below, black, though stained brownish soon after birth; slightly paler (very dark gray) on posterior region of belly. Scattered white hairs on throat and along lower lip, white crescentic spot at each armpit; white spots about $1 \mathrm{~cm}$. in diameter at sites of 4 mammary teats in both sexes, at penial opening, and at ventral margin of anus.

The hair slope or "set" of the hair is hindward and downward from the snout at all stages of development of the fur seal. In related species, however, the birthcoat may have an attractive moiré pattern. I have examined tanned pelts of the newborn Steller sea lion Eumetopias jubata exhibiting a hair pattern somewhat like that of lamb, kid, or pony. Photographic reproductions by Samet $(1950$, p. 356) show that the pelt of the newborn South American sea lion Otaria byronia, the "tropical seal" of the fur trade, also has a rippled pattern.

\section{SYNOPSIS OF PELAGE FIBERS}

In order to make a distinction, I use "underhair" for the fine-fibered layer of the juvenile coat and "underfur" for the homologous layer of the adolescent and adult coats.

The black coat is the first pelage. It is mature (prime) at birth and can be plucked rather easily with one's fingers. Traces of it per- 
sist for 2 or 3 months after birth, that is, from mid-July to end of September, by which time it has been replaced by the pelage of the silver pup, autumn.

The black coat is a temporary body covering, quantitatively as well as qualitatively different from the adult coat. While both juvenile and adult pelages include an overlayer of guard fibers and an underlayer of fine fibers, the sizes and proportions of the fibers in the coats of pup and adult are materially different. For example, the underhairs of the black coat are so thinly distributed that the newborn pup may become soaked to the skin in driving rain, while the underfur of the adult coat is dense and water-repellent.

The black pelage has a light brownish gray basal zone merging gradually with a deep brownish black terminal zone. The two zones are about equal in width (depth). The lighter effect is contributed by the almost colorless underhairs, plus the pale shafts of the guard hairs. The darker effect is contributed by the heavily pigmented blades of the guard hairs. White-tipped guard hairs are rare. A sample area the size of a man's hand, for example, may contain none at all.

The pelage contains 75 to 80 percent underhairs (shorter, finer, and more wavy) and 20 to 25 percent guard hairs (longer, coarser, and stiffer). Measured as they lie in the pelage, the mean lengths of the fibers are shown in table 3. The underhairs are a mixed lot (plate 45). Their tips line up in a ragged rank difficult to measure. In length, they range from 6 to $15 \mathrm{~mm}$. The finest and most abundant ones are fur-like, slender, wavy, without blade, and almost without medulla. The largest ones are miniature guard hairs. The underhairs intergrade completely with the smallest guard hairs. Between the largest underhairs and the smallest guard hairs, however, there is a fairly distinct break in size, though not in shape and structure. All of the hairs are attenuated at the root, showing that they have ceased to grow. The root tends to be roundish in cross section, while the older portions of the shaft are distinctly flattened. All of the fibers taper to sharp points-some to less than 1 micron, near the limit of resolution. All of the fibers contain brown pigment in varying amounts.

A horizontal section from the back of the neck of a full-term fetus is shown in plates 46 and 47 ( $A$ and $B$ ). The follicular bundles are arranged in a honeycomb pattern, about 40 to 45 per sq. mm. Each bundle is embedded in a complex web of connective tissue. Each bundle is seen as a circle of epidermal tissue (with deeply staining nuclei) surrounding 1,2 , or 3 hairs. One's are least common; two's are most common. The hair nearest the anterior edge of the bundle 
is always the largest and is a guard hair. The hairs nearest the posterior edge of the bundle may be either underhairs or small guard hairs. At superficial levels, to a depth of less than $0.1 \mathrm{~mm}$., the hairs are separated from each other within the bundle by $a$ thin, translucent corneal layer. Immediately below, the nucleated root-sheaths begin to appear. Each hair root, with its sheath, is independent until it reaches the common pilosebaceous opening near the surface of the skin. The hair roots sink to a depth of about $1 \mathrm{~mm}$. At the posterior side of the follicular bundle, a group of deeply staining cells may be seen (plate 47-A). Each is the upper part of the structure which will, in late summer, become the adult-type underfur bundle of the silver pup. At depths of 0.6 to $0.8 \mathrm{~mm}$., the primordia of underfur follicles are active (plate 47-B). The follicles are taking shape between, and posterior to, the mature underhairs or small guard hairs of the black-pup pelage. Among the ordinary pup hairs, one can sccasionally see a giant guard hair with root sheath up to 250 microns in diameter. Such a hair is a "premature" adult-type guard hair. In many stages of the fetus, one is able to see an occasional hair of this kind.

\section{GUARD HAIRS: LARGER EXAMPLES}

Slight differences between these and the guard hairs of the adult seal will be pointed out on page 20 . A sample fiber, length $17.5 \mathrm{~mm}$., bends backward at a point about $8 \mathrm{~mm}$. from the tip. The basal half is nearly straight and is light gray; the terminal half or blade is nearly straight and is deep brownish black. The fiber is strongly flattened except at its root, which is attenuated and roundish in cross section.

The tip is about $0.8 \mathrm{~mm}$. in length, very sharp. The blade is about $8 \mathrm{~mm}$. in length and 18 by 157 microns in cross section. The crosssection shape is crescentic, with the concave side facing posteriorly. The shaft is flattened-elliptical in cross section, 25 by 82 microns. The basal region of the shaft is slightly wider, 89 microns. The root is 25 by 42 microns and tapers toward the base.

The pigment is brown, distributed in fine, barely visible granules in the cortex along most of the shaft, becoming much heavier in the blade. Here it is intense brownish black, evenly distributed through the cortex, both in grains and in little packets of grains aligned with the long axis of the fiber. The tip of the fiber is distinctly pigmented; the root is clear. (The next crop of fibers, the replacement crop, will consist of adult-type guard hairs, most of them white-tipped.)

A medulla is absent from the tip. About $0.8 \mathrm{~mm}$. from the tip, a blade with a conspicuous, unbroken (medium wide) lattice type of medulla begins to appear. The medulla continues to the basal end of the blade, where it becomes broken for a distance of $1.5 \mathrm{~mm}$., then 
again unbroken. Where the main part of the shaft is 82 microns wide, the medulla is 53 microns wide. The root is without medulla.

The cuticular-scale pattern at the tip is coronal, irregular, margins smooth. It resembles the pattern of the underhair tip. The pattern of the blade is waved, irregular, margins smooth to rippled, near. The main part of the shaft is diamond petal, margins smooth.

\section{GUARD HAIRS: SMALLER EXAMPLES}

These are small shield fibers varying in length from 10 to $15 \mathrm{~mm}$. As compared with the larger guard hairs, they are more flexible, wavy, and slender. They have a shorter, less conspicuous, and narrower blade. They usually have a swollen base which the large guard hair does not possess, and the medulla tends to be broken rather than unbroken. The color of the blade is brown, elsewhere the hairs are pale gray. The tip is finer, more attenuated, than on the larger guard hair.

On a typical small guard hair $13 \mathrm{~mm}$. long, the blade is 4 or $5 \mathrm{~mm}$. long, with a cross section 16 by 71 microns. The cross section is more elliptical, less crescentic, than in larger guard hairs. Cross sections of the shaft (main part), shaft (basal region), and root are, respectively: 16 by 46,28 by 68 , and 18 by 24 microns. Thus, the basal region is nearly as wide as the blade.

Pigment is distributed as in the larger guard hairs, though more sparsely. It starts in the tip, is heaviest in the blade, is lightest in the shaft, and is absent from the root.

A medulla is absent from the tip and terminal part of the blade; broken (interrupted) narrow in the widest part of the blade; broken (fragmental) in the basal part of the blade; gradually increasing toward the root until it becomes unbroken (medium wide) lattice, as in the shaft of the large guard hair. A medulla is lacking in the root.

The scale pattern is diamond petal, margins smooth, along most of the shaft, as it is on the larger guard-hair shaft. On the blade, it is more nearly wide, irregular petal. Little distinction can be made between the patterns of a small and a large guard hair.

\section{UNDERHAIRS}

The following description applies to the abundant fine hairs and not to the less abundant coarser hairs which resemble guard hairs. The underhairs are strap-shaped, clearly spiral, making 2 or 3 complete waves (as viewed in one pline), slender, and without blade. They range in length from 6 to $10 \mathrm{~mm}$. The terminal one-third of the underhair fiber, corresponding to the blade of the guard hair, is pale golden brown; the basal two-third nearly colorless. 
The tip is long and slender; blade absent; shaft cross section 12 to 14 by 20 to 22 microns, changing but little in size along its length. The basal region, however, is distinctly swollen, to 24 by 40 microns. The root is extremely slender, 8 by 10 microns.

Pigment, in the form of golden-brown granules, flecks, and streaks, is plainly visible in the tip in the terminal one-third of the fiber. It gradually becomes paler and more diffuse toward the base. A few granules can be seen even in the root.

A medulla is present only in the swollen basal portion of the shaft. Here, where the shaft is 36 microns wide, the medulla is 20 microns wide, unbroken (medium wide) lattice. This section of medulla is joined on both ends by a short section of broken medulla.

The cuticular-scale pattern is coarse pectinate near the tip, diamond petal, irregular, along most of the shaft; diamond petal, regular, on the basal swollen part. The scale margins are smooth.

\section{Black Pup, Molting (Sexes Lumped)}

The coat is brownish black, beginning to pale on face, flanks, and belly; coarser and duller than on the newborn (plates 48 and 49). Dorsal aspect: generally dark grayish brown (Munsell 5 YR 2/1); paler on top of snout, upper lip, and flanks. Many hairs on crown and back of neck are white or white-tipped. Bases of flippers are assuming the deep-brown color of the adult. Ventral aspect: generally dark grayish brown (5 YR 2/1); paler on lower lip, chest (but not throat), and belly. Armpits, around mouth, and around penial opening stained dark orange yellow (7.5 YR 6/6); posterior region of belly stained brown; whitish spots at the mammary teats still visible in some specimens.

A brief description only will be given of the fibers of the transition stages between black pup (newborn) and silver pup (plate 50). On the back pelage of a female taken on 11 August, weight $9.3 \mathrm{~kg}$. (201/2 lb.) adult-type underfur fibers and guard hairs are beginning to appear among the pup hairs. A fur buyer would say that the new pelage is starting to "peep," or that the pelt is in the "peepy" stage. Many underfur fibers-fine, nonmedullated, and in bundles-have moved up to the level of the pup underhair tips. Slightly below them, adult guard hairs have moved out in even rank, their pigmented blades collectively giving the effect of a distinct dark-gray band at the base of the pelage. This band is $4 \mathrm{~mm}$. wide. Where the bases of the pigmented blades are still buried in the skin or leather, they show as black vertical streaks.

On the crown of a female killed 22 September, weight $12.2 \mathrm{~kg}$. (27 lb.), the shedding black pup hairs contrast sharply with the new crop of white-tipped guard hairs. 
On the back pelage of a male taken on 29 September, weight 14.7 kg. $(321 / 2 \mathrm{lb}$.), the fall molt is nearly complete. In thickness and resiliency, as judged by one's fingers, it ranks between the pelage of the black pup and the silver pup. Underfur is thin. Adult-type guard hairs have almost completely replaced pup overhairs. A few unshed pup hairs show like black tree trunks in a forest of light underfur. The surface of the pelage now has a pepper-and-salt effect imparted by the white tips of the guard hairs. The dark band seen in the 11 August specimen has moved out beyond the underfur. The leather is paler, now that the guard-hair blades have passed through it. While at the surface of the skin no fiber of any kind contains pigment, intensely black pigment groups can be seen at the papillary level of certain fiber roots, showing through the translucent leather. These groups probably represent melanocytes of the forthcoming crop of fibers.

\section{Silver Pup (Sexes Lumped)}

\section{SYNOPSIS OF COLOR PATTERN}

Dorsal parts rather uniform dark gray; face with conspicuous "mask"; armpits and rump patches pale (plates 51 and 52, A and B). First appearance of rump patches; light-colored streaks, each about $3 \mathrm{by} 8 \mathrm{~cm}$, extending forward from the level of the knee. On ventral side, pale belly and anterior region of chest contrast with dark throat and posterior region of chest. Underfur silvery gray. Sexes indistinguishable on basis of color pattern. (Further details are given in appendix A.)

\section{SYNOPSIS OF PELAGE FIBERS}

From the black coat-its predecessor-the silver coat differs mainly in having underhairs, now called underfur fibers, which are longer, curlier, paler, and in definite bundles; guard hairs somewhat shorter and mostly white-tipped. From the autumn yearling coat-its successor-the silver coat differs mainly in having underfur fibers which are whitish rather than cinnamon-colored, and are straighter, less curly.

A strip cut from the back of the silver pup shows a whitish layer of underfur $11 \mathrm{~mm}$. wide, topped by a black band $5 \mathrm{~mm}$. wide (representing the guard-hair blades) and a white band $1 \mathrm{~mm}$. wide (representing the guard-hair tips). The underfur fibers are twisted in 5 to 7 gentle waves. The pelt has a pepper-and-salt appearance. On the living animal, the guard hair does not readily part itself to show the underfur. On the black pup, by contrast, a driving rain may part the thin black overcoat, revealing the light underhair 
as a streak from forehead to rump. Measured as they lie in the pelage, the mean lengths of the fibers are shown in table 3.

The fiber population consists of underfur fibers about 97.5 percent, small guard hairs 2.25 percent, and large guard hairs 0.25 percent. The underfur fibers are very distinct from the large guard hairs. The small guard hairs resemble the underfur fibers in size, the large guard hairs in structure. Since the small guard hairs stand alone rather than in bundles, are medullated, and have a blade, they are clearly to be regarded as guard hairs rather than underfur fibers. In a mid-October specimen, all fibers have attenuated roots, though they are still growing.

\section{GUARD HAIRS: LARGER EXAMPLES}

These important hairs are responsible for the over-all effect of color, texture, and pattern of the seal's coat. Judging from photographic illustrations by Wildman (1954), fur-seal hairs resemble most closely those of the American mink (Mustela vison) and the Asiatic mink or kolinsky ( $M$. sibirica), somewhat less closely those of the otters (Lutra sp.). The large guard hairs of the silver pup and adult fur seal closely resemble, in size and structure, the large overhairs of the black pup. Differences are minor. For example, the pup overhair tapers more suddenly to a point and is pigmented to the tip; the adult guard hair tapers more gradually and usually has a colorless tip. A large specimen is $22 \mathrm{~mm}$. long, flattened, nearly straight in dorsal or ventral view, bent backward near the middle in side view. The bend is at a point one-third to one-half the distance along the shaft from the tip. The terminal one-third of the shaft is widened into a blade. The basal half is colorless, the terminal half (except for tip) is brownish black.

The tip is $1.5 \mathrm{~mm}$. in length and very sharp. The blade is 8 to 10 $\mathrm{mm}$. in length, and has a flattened elliptical (boat-shaped) cross section whose diameters are 35 by 158 microns. The main shaft cross section is 32 by 118 microns. The shaft is nearly uniform in width, or slightly smaller toward the base. The root is 0.8 to $1.0 \mathrm{~mm}$. long and 32 by 55 microns in diameter.

Pigment is in granules and longitudinal streaks, evenly distributed throughout the medulla. It is absent in the terminal $1.5 \mathrm{~mm}$. Toward the middle of the blade, it becomes intense brownish black, obscuring most other structures. It is absent from the basal half of the hair.

The tip is nonmedullated. In the blade, the medulla is conspicuous, unbroken (medium wide) lattice; 65 microns wide where the blade is 118 microns. It becomes broken (interrupted) near the middle of the shaft, below the blade; then gradually increases in importance toward the base. At the base, it is unbroken (wide) lattice, 85 microns wide where the shaft is 114 microns. The root is nonmedullated. 
The cuticular-scale pattern is similar to that of the small guard hair just described. Where the scale margins are slightly crenate to smooth on the smaller hair, along tip and blade, they are crenate on the larger hair. The transition region at the base, between petal and mosaic, is 0.4 to $0.5 \mathrm{~mm}$. in length.

\section{GUARD HAIRS: SMALLER EXAMPLES}

Small guard hairs are clearly distinguished-for example, by presence of medulla and by solitary position-from underfur fibers. (In the black-pup coat, it will be recalled, small guard hairs intergrade with underhairs.) Small guard hairs outnumber the large ones by about 10 to 1 , but are less conspicuous because of their inferior position, narrower width, and paler color. A typical small guard hair is $14 \mathrm{~mm}$. long, strap-shaped, with 4 or 5 gentle waves, a distinct but narrow blade along the terminal one-third of the shaft, and a slightly swollen base. It is mainly colorless, with brown pigment beginning about $11 \mathrm{~mm}$. from base, becoming deep brownish black in blade, paling toward tip, giving the effect of a colorless tip about $0.2 \mathrm{~mm}$.

The tip of the hair is very sharp. It increases in size for a distance of 0.2 to $0.3 \mathrm{~mm}$. toward the blade. The blade is about $3 \mathrm{~mm}$. long, with cross-section diameters 14 by 90 microns; cross-section shape an ellipse flattened on the posterior side. The main part of the shaft has cross-section diameters 14 to 18 by 30 to 35 microns. The basal one-third of the shaft is thicker than, and nearly as wide as, the blade, or 25 by 70 microns. The root is 1.0 to $1.2 \mathrm{~mm}$. long, with cross-section diameters 15 by 20 microns.

Pigment granules and streaks, evenly distributed in the cortex, begin about $0.2 \mathrm{~mm}$. from the colorless tip. Pigmentation becomes intense, though never as intense as in large guard hairs, in the middle of the blade, about $1 \mathrm{~mm}$. down from the tip. Pigment granules gradually disappear below the middle of the shaft. The basal half of the shaft is colorless.

The medullary pattern varies with the size of guard hair. In a 14-mm. hair, the medulla is lacking in the tip. It is broken in the blade, disappears in the middle third of the shaft, and becomes conspicuous, unbroken (wide) lattice toward the base. At a place where the shaft is 53 microns wide, the medulla is 40 microns.

The cuticular-scale pattern at the tip is coronal to irregularly waved mosaic, margins smooth (compare Wildman, 1954, fig. 102d, mink). On the blade, it is irregularly waved mosaic, margins slightly crenate to smooth (compare Wildman, 1954, fig. 94b, kolinsky). Along the shaft, it is diamond petal, margins smooth (compare Wildman, 1954, fig. $99 \mathrm{a}$, otter). It changes rather abruptly along the basal 0.3 to 
$0.4 \mathrm{~mm}$. of the shaft to irregularly waved mosaic, margins smooth, on the root (compare Wildman, 1954, fig. 94b, kolinsky).

\section{UNDERFUR FIBERS}

These are strap-shaped, twisting in many planes, slightly wider and thicker in terminal third than in basal third, nearly colorless along basal two-thirds and pale brown along terminal one-third; cross section more roundish near base, more elliptical in terminal one-third. They are in bundles of 35 to 40 . They stand slightly posterior to the guard hairs.

The tip is less than 1 micron wide and about $1 \mathrm{~mm}$. long, with a gradual taper. The terminal one-third of the fiber has cross-section diameters 6 to 7 by 12 to 15 microns; the basal one-third, 3 to 4 by 6 to 7 microns. In between, the shaft diameters are transitional in size. The attenuated portion of the root lies entirely within the skin. It is virtually without structure; clear, smooth, and 5 microns in diameter.

Pigment is distributed thinly and evenly in the terminal one-third of the fiber in dark-brown granules and longitudinal streaks. Pigment is absent from the basal one-half to two-thirds of the shaft. When mounted in o-dichlorobenzene, the basal region becomes almost invisible. (This mountant has a refractive index of 1.552 , as compared with 1.548 for keratin.) A medulla is lacking.

The cuticular-scale pattern, starting from the tip, is coronal to waived mosaic, margins smooth. Along the shaft it is pectinate, margins smooth. It is similar to that on the underfur fibers of mink (compare Wildman, 1954, figs. 94e and 102c and d). The tooth of each scale curls slightly outward, giving the fiber a rather rough silhouette.

The remarkable ability of the underfur to trap air bubbles and repel water has long been known. Conrad Limbaugh, a professional diver, has written (personal correspondence, 1957) of an undersea observation of a Philippi fur seal off Isla de Guadalupe, Mexico, in late November:

Daring our stay, the fur seal became more and more aggressive, occasionally rashing us with a characteristic spin, emitting strings of bubbles from various points on its pelt, especially from behind the ears . . . During all activities bubbles streamed from various points of the pelt so that the seal left a trail of bubbles.

\section{Yearling, Pelagic (Sexes Lumped)}

The yearling, pelagic, continues to wear the coat of the silver pup, though with individual fibers now grown to full length (plate 53). It may be seen in table 3 that, between mean dates of 25 October and 
22 April, while the silver pup is changing to yearling, the underfur and guard-hair fibers increase in length 5 or 6 percent.

The first crop of underfur, appearing on the silver pup, is whiter than all subsequent crops. It may take on a slight brownish stain in winter, spring, and early summer. The second crop (yearling, autumn) is definitely more pigmented, more pinkish brown, than the first. And when the third crop erupts (2-year-old, autumn), it is cinnamon-colored like that of the adult.

On an emaciated female yearling, weight $5.0 \mathrm{~kg}$. (11 lb.), taken alive on the Washington coast about 15 January, the underfur of the back was pinkish white (Munsell 7.5 YR 8/2), the pelage prime. On another female yearling, weight $9.5 \mathrm{~kg}$. (21 lb.), taken at sea on 29 April, the underfur fibers of neck and back were also 7.5 YR 8/2, those of the belly pinkish gray (7.5 YR 6/2).

\section{Yearling, Autumn (Sexes Lumped)}

Dorsal parts medium gray; cheeks pale; mask conspicuous, though not as distinct as on the silver pup; anterior region of chest and flanks pale; chest between flippers distinctly brownish (a variable character); bases of flippers and adjacent regions of body much browner than on the silver pup; belly often distinctly pinkish; color patterns of male and female indistinguishable (plates 54 and 55).

As compared with the skin of older animals, the yearling skin seems more elastic and more lively; it curls more readily when cut from the body, and it floats higher on water. The color of the underfur is not yet as dark as that of the adult. On a male taken 26 September, the fur is light grayish brown to brownish pink (7.5 YR 6/2 to 7/2), except near the bases of the flippers, where it is darker. On a female taken 3 October, the fur is brownish pink (7.5 YR 7/2).

\section{Three-year-old, Adolescent Male (Bachelor)}

Dorsal parts rather uniform brownish gray, relieved by tan cheek and top of snout; ventral parts alternate dark on throat and posterior region of chest, pale on anterior region of chest and belly. The juvenile mask has almost disappeared; rump patches are beginning to disappear; crown or "wig" hairs are beginning to lengthen and stand erect. (See similar pelage in plates 56, 57, and 92.)

\section{Three-year-old Adolescent Female (Young Cow)}

Dorsal parts rather uniform brownish gray; ventral parts relieved by band of light yellowish brown across chest, along upper lip and cheek, and on top of snout; belly grayish brown. Color pattern usu- 
ally indistinguishable from that of the male, though the female tends to have paler upper lip (mustache line) and throat and never has a coarse wig. Rump patehes are usually present on both male and female 3-year-olds; are never seen on males older than 4 years; are occasionally seen on the oldest females.

\section{Adult Male (Bull)}

Bulls with clean pelage, resting on clean sand in late summer, give the impression of gray or dark gray animals. A few individuals are pale warm gray or brownish; a few are almost black. As compared with the female, the adult male has retained only a moderately pale face, and has attained a light gray mane and wig. Rump patches have disappeared entirely (plates 58 and 59 ).

The specimen described in appendix $\mathbf{A}$ was rather monotonous dark grayish brown; ventral parts somewhat lighter and browner than dorsal: face not conspicuously marked; hairs varicolored over most of body, giving at close range a pepper-and-salt effect.

The guard hairs of the mane of the adult male are the largest of any fur-seal hairs except the vibrissae. A specimen hair is $70 \mathrm{~mm}$. in length with a blade 89 by 240 microns in cross section; about four times as long and twice as wide and thick as a large guard hair from an adult female. While the mane hair is an awn type, the blade does not flare out as abruptly as on the ordinary guard hair, but is wide for one-half to two-thirds the length of the shaft. The cross section of the shaft is, near the tip, ovoid with a concave posterior side; in the blade, more flattened, though still with a faint concavity; near the base, cigar-shaped without concavity.

The longest mane hairs are white, without pigment. Medulla is absent from the base; broken (fragmental to interrupted) along most of the shaft, becoming unbroken (medium wide) lattice in the terminal $10 \mathrm{~mm}$. When sunlight strikes a white mane hair, it is reflected from the colorless cortex and the gas-filled cells of the terminal medulla, giving a halo effect (plate 59).

\section{Adult Female (Old Cow)}

Most adult females are light-colored across face, chest, and belly. Virtually all have a pale band along the upper lip, from one corner of the mouth to the other, extending at times to the bridge of the nose, backward to the cheeks, and above and behind the eyes. A pale streak along the lower lip is not as bright as that on the upper. Seen from the front, the face is often mask-like, with black, naked nose in center and shiny black eye on each side. While some females are monotonous dark brownish gray, all have a paler face, chest, and belly. Rump patches are rarely visible. (Plates 60-62.) 

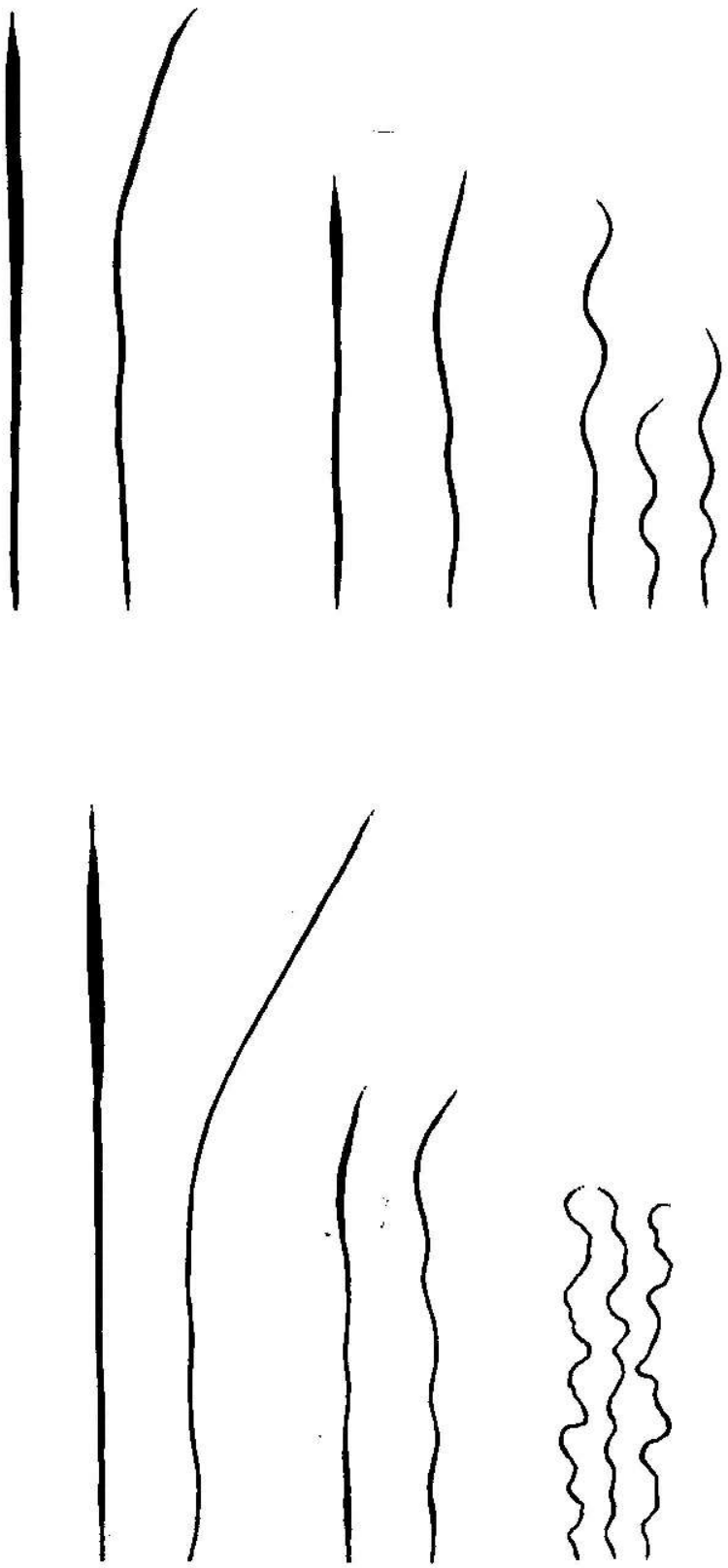

Froune 1.-\$ketches representing (left to right) : 2 large guard hairs in front and side view ; 2 small guard hairs in front and side view, and 3 underhairs or fur hairs; about $\times 3$. (Above) Birthcoat. (Below) First adult-type pelage, on the sllver pup of autumn.

(4186 and 4187) 


\section{Variation in Length of Pelage Fibers With Age and Sex}

The data in table 3 suggest that the prime underfur fibers of the first crop, on the yearling, pelagic, are about as long as those of subsequent crops. The following changes in mean length throughout life are noted (7-year-and-older males and 7-year-and-older females, compared with yearlings, pelagic, sexes lumped): Male-neck, increase 14 percent in length; back, increase 10 percent; belly, decrease 9 percent. Female-neck, decrease 5 percent; back, decrease 4 percent; belly, decrease 9 percent.

With respect to the guard hairs also, one may conclude that the only real changes with advancing age are those in length of the mane hairs and back hairs of the male. From yearling, pelagic, to adult the following changes in mean length are noted : Male-neck, increase 156 percent in length; back, increase 30 percent; belly, increase 7 percent. Female-neck, increase 1 percent; back, decrease 4 percent; belly decrease 11 percent.

Sex discrepancy in length of pelage fibers first appears during adolescence, in the 3-and 4-year-olds. In 7-year-old and older animals, the male fibers are seen to be longer than the corresponding female fibers by the following percentages : Neck-underfur 23 percent, guard hair 153 percent. Back-underfur 15 percent, guard hair 35 percent. Belly-underfur 0 percent, guard hair 20 percent. The real relation, of course, is perhaps between length of pelage and body size, since the adult male is about 4.5 times as heavy as the female of the same age (Scheffer and Wilke, 1953, p. 145).

It has been mentioned that, regardless of age after 2 years and regardless of sex, the follicular or hair-root portion of the skin does not vary appreciably in thickness from 2.3 to $2.4 \mathrm{~mm}$.

\section{Variation With Season: The Annual Molt}

Certain aspects of growth and replacement of hair have been described. It will now be helpful to discuss the whole phenomenon of molt, the autumnal turnover in which the pelage passes by degrees through "staginess" into "primeness."

\section{FIRST MOLT}

In the first molt, the coat of the black pup, newborn, is replaced by the adult-type coat of the silver pup, autumn. The molt starts at birth (mid-July), though it does not show on the surface for about 2 weeks. By mid-September about half of the pups, and by midOctober all of the pups, have acquired a silvery gray pelage which is nearly adult in character. It is a warm coat that will protect the 
pup during its first migration through the icy waters of Bering Sea in October and November. An individual termed a "silver pup" will be designated arbitrarily on the first of January as a "yearling, pelagic" though it undergoes no change in pelage at this time.

\section{SECOND MOLT}

In the second molt, the coat of the yearling, pelagic, is replaced by that of the yearling, autumn. The two coats are similar. It is believed that less than half of the members of the yearling age-class reconvene on the breeding grounds in their second autumn of life. Those that do, return late in autumn, mostly after the first of October. Members of all other age-classes return in nearly full numerical strength and much earlier in the season, from May to August, depending on their age. Most of the yearlings seen on land in autumn have already molted into their second adult-type pelage, though growth of the fibers has not quite ceased.

Shearing experiments carried out on a male and female silver pup in Seattle Zoo throw light on the second molt. Patches were shorn by electric barber-clippers on 24 November 1952, when the pelage was judged to be prime. Length of underfur was 12 to $13 \mathrm{~mm}$.; of guard hair 21 to $22 \mathrm{~mm}$. One month later the patches had changed from whitish to pale reddish brown, and had assumed a faintly "stubbly" texture. Both changes were probably the result of exposure rather than of fiber growth. Two months later, on 30 January 1953, the patches were seen to be unchanged. On 5 July 1953, slight regrowth of underfur-but not of guard hair-could be seen from a distance of 6 feet. By 31 July the shorn patches were covered with brown underfur to a depth of 3 to $5 \mathrm{~mm}$. No guard hair could be seen or felt. On 4 September, the fur was growing rapidly; depth now 12 to $13 \mathrm{~mm}$., brownish. Sparse new guard hair was starting to appear. Growth of guard hair was further advanced $(20 \mathrm{~mm}$.) on the male rump patch than on the female shoulder patch $(16 \mathrm{~mm}$.). On 17 September 1953, the male weighed $20.2 \mathrm{~kg}$. and the female $15.4 \mathrm{~kg}$.; both in good health. "Apparently the underfur is fullyor almost fully-developed. The guard hair is about half as dense on the shaved spots as on the surrounding areas" ( $K$. W. Kenyon, personal correspondence.). On 26 October 1953, the female died. The underfur of her shoulder patch was slightly browner than adjacent normal underfur and had perhaps not attained its full growth. On 16 April 1954 (as a 2-year-old, spring), the surviving male was beginning to lose weight; rump pelage normal; underfur color light reddish brown (Munsell 5 YR 6/3). On 14 May 1954, he died. 
In summary, the new underfur started to grow in early July and was nearly full grown by mid-August. The new guard hair started to grow about mid-August and was full grown by the end of September.

On the tanned pelts of 17 yearlings killed 7 October to 7 November 1941, there are no black dots, signs of unprimeness, on the leather side. On the earliest specimen that I saw, taken 26 September, the pelage appears to be prime, though horizontal-section slides show clearly that a few new guard hairs and a few fur fibers are still growing-that is, in certain follicular bundles, both the cylindrical root of the old guard hair and the elliptical blade of the new guard hair may be seen (plates 63 to 64 ), and behind the cylindrical roots of certain old fur fibers, the elliptical shafts, faintly pigmented, of new fibers may be seen. On a yearling taken 3 October, the molt is obviously not complete. About $5 \mathrm{~cm}$. anterior to base of tail a sharp molt line encircles the body (plate 65). Anterior to this line the pelage is denser and more silvery ; posterior to the line, thinner, duller, and browner. Fur hairs are $11 \mathrm{~mm}$. in length and brownish pink on the anterior region; $5 \mathrm{~mm}$. in length and distinctly brown on the posterior region. One rarely sees such a molt line on a fur seal.

The lengths of underfur and guard-hair fibers on 20 yearlings, autumn, are shown in table 3 . The fibers on neck and back have increased slightly in length over those of the pelagic coat; the fibers on belly have increased materially. The belly fibers are, in fact, as long as they are ever to be on animals of older ages. The belly coat of the fur seal, including both underfur and guard-hair layers, is relatively thin over a wide area. (Why?)

\section{THIRD MOLT}

The third molt is experienced by seals entering their third year of life, that is, by "two-year-olds" (plates 66 and 67). Two-year-old males and females, though preadolescent, have now been caught up in the annual rhythm of return to the breeding grounds in summer. Whereas the second molt was centered in August, the third is centered in September. Eight specimen skins taken 20 August to 24 September are stagy, with short guard hairs and with dark areas on the leather side of the pelt. As indicated in table 3, the fibers are shorter than on samples of yearlings and 3-year-olds. One may deduce that most of the old fur and guard-hair fibers have dropped out of the 2-year pelt by the end of August.

On St. Paul Island, from 7 to 23 September 1956, a sample of 122 skins from females of all ages was graded for staginess by an em- 
ployee of the Fouke Fur Company. The following numbers of skins were rejected as being commercially unusable:

\begin{tabular}{|c|c|c|}
\hline $\begin{array}{l}\text { Number } \\
\text { killed }\end{array}$ & $\begin{array}{l}\text { Number } \\
\text { rejected }\end{array}$ & $\begin{array}{l}\text { Percent } \\
\text { rejected }\end{array}$ \\
\hline 2-year-olds_ & 6 & 75 \\
\hline 3-year-olds_- & 7 & 50 \\
\hline 4-year-olds__. 21 & 2 & 9 \\
\hline 5-year-olds & 3 & 33 \\
\hline 6-year-olds & 3 & 25 \\
\hline 7-year-olds & 1 & 8 \\
\hline 8-year-olds & $\mathbf{0}$ & 0 \\
\hline 9-year-olds & 2 & 67 \\
\hline 10-year-olds & 3 & 100 \\
\hline Over 10 years old & 3 & 37 \\
\hline$\overline{92}$ & $\overline{30}$ & $\overline{33}$ \\
\hline
\end{tabular}

The sample is too small to be very useful. It does suggest that September molt is more pronounced in the 2-year-olds than in older females.

It has already been noted that the true cinnamon color of the adult underfur is first attained at the conclusion of the third molt.

\section{FOURTH MOLT}

The fourth molt is experienced by the 3-year-olds and is centered around the end of September. The 3-year-old males contribute more importantly than any other age-class to the annual yield of sealskins. Molt during the regular killing season--up to mid-August-has never posed a technological problem to the fur processors.

On a horizontal section from the back of a 3-year-old male, killed 27 September, about 1 follicular bundle in 10 contains the wide blade of a newly erupting guard hair. A 3-year-old female shorn in captivity in early September 1957 had not quite recovered by 7 February 1958. That is, the new growth of autumn 1957 had evidently started in late August. On the tanned skin of a bachelor killed on 23 September, there are distinct dark, unprime areas. On a 3-year-old male killed on 27 September 1958, shed underfur was clinging abundantly to the hind claws.

Records from the period 1874-77, when Pribilof natives were permitted to make autumn "food killings", are of interest here (Jordan and others, 1898, p. 2̇2 $266,267,269)$ :

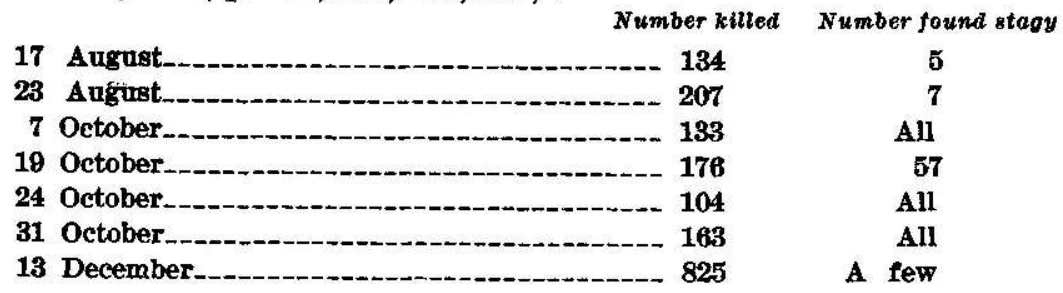


The food killings were made largely from the bachelor class. These records show that molt was conspicuous in the month of October.

There is evidence that growth of the new underfur may begin as early as July. Annually in summer, from 1904 to 1932 , Government agents on the Priblofs used to mark a few thousand bachelor seals by shearing the top of the head. Whenever a shorn animal appeared later in the summer on the killing field it was spared as a "breeding reserve" (Scheffer, 1950 b, p. 7-8). One year later, however, the guard hairs had recovered, and at this time the killing crew inadvertently knocked down a few large bachelors that had been shorn the previous summer. A veteran Fouke Fur Company employee has written (personal correspondence) that "after the [marked] skins had gone through processing and the guard hair had been removed, it was discovered that the underfur had not grown out to any degree." On the basis of modern information, this phenomenon can be explained. For example, young underfur fibers of an individual were shorn in August 1930. In July. 1931 the seal was killed, wearing a short underfur coat of two components: the stumps of the 1930 season and the new, short growth of 1931.

The fibers of the 3-year-old (except, perhaps, those of the neck) are no longer than those of the silver pup and yearling (table 3). Within the 3-year class, the fibers of the female are beginning to lag behind those of the male.

\section{MOLT IN ADULTS}

There is little evidence on molt in adults with relation to calendar date. Quite certainly, however, it is centered in October, somewhat later than molt in the 3-year-old. Employees of the Fouke Fur Company have long recognized that stagy skins are seen more often in younger males (3- and 4-year-olds) than in older ones (5- and 6-year-olds) at any given time in late summer.

On a 5-year-old female in Seattle Zoo, shorn in early September 1957, the pelage had recovered by 7 February of the following year. In other words, all of the new fibers erupted after early September. (The reader will recall that on a 3-year-old companion, shorn and killed on the foregoing schedule, the pelage had not quite recovered by 7 February because the younger animal had started to grow a new crop of fibers in August.)

I have examined median sections of skin from adult seals, age 7 years or older, taken in September 1958, including 2 males and 26 females. On all of the sections, melanocytes in the guard-hair follicles are still active. No club hairs can be seen.

In all six hind claws of an old female lying on the beach on St. Paul Island, 25 September 1958, there were tufts or balls of underfur, 2 to $5 \mathrm{~mm}$. in diameter, scratched from the pelt. 


\section{COMPARISON WITH MOLT IN OTHER FURBEARERS}

The phenomenon of molt in furbearing animals has been studied by Gunn (1932) in muskrat, by Bissonnette $(1935,1942)$ in ferret and weasel, by Bissonnette and Bailey (1944) in weasel, by Bassett, Pearson, and Wilke (1944) in fox, by Bassett and Llewellyn $(1948,1949)$ in fox and mink, by Hall (1951) in weasel, by Rothschild and Lane (1957) in ermine, and by Shanks (1948) in muskrat. Molt begins in one or several places on the body. and proceeds outward in waves. Most of the fibers along the front of a wave are in the same stage of molt. (In man, however, molting is mosaic, with new hairs popping up here and there to replace old ones.) New hair or fur growth is signaled by a massing of pigment in the follicles. This massing gives a dark bluish cast to the body side of the pelt. The new hairs erupt as the old hairs are being shed, although the momentum of new growth usually carries on for a while after shedding is complete. The stimulus or triggering mechanism in molt is change in length of daylight, which stimulates in turn the optic nerve, the anterior hypophysis (pituitary), and the hair-growth cycle. Melanocytes have already ceased to function while the hair shaft is still completing its growth in length. Thus, in a prime pelt, pigment is absent both from the dermis and from the attenuated base of the shaft. In some species, molt may be a rather long process; in the silver fox it begins in early May, when simultaneously the old hairs start to drop out and the new ones to appear. (Growth and maturation of the guard hair precede that of the underfur.) About 41/2 months later, by mid-September, the old hair is shed. The new hairs continue to grow, and pigment continues to leave the skin, until about the first of December, or date of primeness. In general, the direction of the molt is: legs, rump and tail, abdomen and sides, back, mane and crown.

Molt in the fur seal is an annual event, as in the silver fox but not in the mink, where it is semiannual. Molt in the fur seal is rather slow, requiring 4 to 5 months' time. It is gradual and unobtrusive. Old fibers are shed singly as the new ones erupt. Thus the seal at all times has a warm, water-repellent coat. As previously mentioned, a distinct molt line is not often seen. The molt is not accompanied by profound changes in the epidermis. In certain phocids (elephant seal, Weddell seal, and monk seal), great tatters of epidermis peel from the body along with the newly shed hairs. No pinniped has more than two fundamentally distinct pelages: juvenile and adult. The juvenile coat may be shed, for example, in the harbor seal, shortly before birth. While in some species, the harp seal, for example, the pelage may molt several times before it assumes its mature pattern. its only real break in character is with the juvenile coat. 
Rand (1956) has given a good description of molt in the South African fur seal Aretocephalus pusillus. Molt here seems to differ from that in the northern fur seal only in the longer time required for the black birthcoat to disappear. In the pup coat of Arctocephalus, change is not visible until the animal is 2 months old or older, and the coat persists nearly 4 months. The corresponding periods for Callorhinus are 6 weeks and $21 / 2$ months. The second molt in Arctocephalus, between December and February, corresponds to that of Callorhinus, between June and August. (Incidentally, commercial sealing in South Africa is largely directed against the yearling animal, 8 to 10 months old; while in Alaska it is directed against the 3- and 4-year males.)

\section{The Sensory Vibrissae}

All mammals, with the exception of man, are reported to have, at some time in life, special sensory bristles on or near the face. Even whales may have as many as 80 such bristles, their function supposedly to detect water currents and macroplankton food (Nakai and Shida, 1948). According to Pocock (1914), the sensory vibrissae may be classified according to location as mystacial, superciliary, genal, submental, and interramal. The presence of all five on one kind of mammal is thought to be primitive. According to Noback $(1951$, p. 481$)$, the vibrissae may also be classified as active tactile hairs, under voluntary control; as passive tactile hairs, not under voluntary control; as follicles with a circular sinus; as follicles without a circular sinus.

In pinnipeds, only the mystacials and superciliaries are retained (plate 34). In all otariid seals, the superciliaries are unimportant; in phocid seals, well developed.

I have made only a cursory examination of the vibrissal roots and surrounding tissues in the fur seal (plates 68, A and B, and 69). Brondsted (1931) gave 7 diagrams of the snout musculature and innervation of the California sea lion Zalophus, a close relative of the fur seal. He described the nasal muscle as being "colossal" in pinnipeds. According to Miller (1952 and in personal correspondence) certain features of anatomy of the dog may (?) resemble those of the fur seal. In the dog, the vibrissae are moved by two sets of muscles: levator nasolabialis and, beneath it, maxillonasolabialis. The vibrissae are supplied from at least one cranial nerve: the trigeminal (5th cranial), mixed motor and sensory, leading to its maxillary division and thence through the infraorbital foramen to the infraorbital nerve. Whether the facial (7th cranial) nerve, 
motor only, leading to the dorsal buccal nerve, plays a part also is uncertain.

\section{PRENATAL DEVELOPMENT OF THE VIBRISSAE}

On the evidence of 14 male male fetuses and 10 female fetuses, the formula for mystacial vibrissae in the fur seal does not vary with sex or age. On each side of the snout there are 5 or 6 rows containing (from top to bottom row) the following number of vibrissae: 0 or $1 ; 3,4$, or $5 ; 5$ or $6 ; 5$ or $6 ; 3=20$ to 23 (plate $70-A$ ). The observed mean total in males is 21.4 and in females 21.1. On all of the fetuses there are two superciliaries on each side of the head; the upper one distinctly longer than the lower.

On the South African fur seal, Rand (1956, p. 10), has found up to 33 mystacial and 2 superciliary vibrissae on each side of the head. A common formula for mystacials is: $3-5-6-6-6-4=30$. Like those of Callorhinus, the vibrissae of the southern seal are black at birth, later turning white.

\section{Fetus of 23.7 g. (0.0049 MNW), female, 14 February}

On this smallest fetus in the collection, the complete vibrissal pattern is set, though several of the individual bristles have not yet erupted. There are no visible signs of additional, rudimentary (vestigial) bristles. Vibrissa formula : $1-3-5-5-6-3=23$. The outermost (posterolateral) vibrissa in the row-of-six is the longest, $0.8 \mathrm{~mm}$. The inner (anteromedian) bristles are still beneath the epidermis, though ready to erupt. Each erupted bristle is sheathed nearly to its tip in a thick, translucent, tubelike extension of the skin. Black pigment can be seen in the larger vibrissae. It is likely present also in the smaller ones though obscured by epidermis. Two superciliaries can plainly be seen as white parallel lines beneath the skin, each $0.8 \mathrm{~mm}$. in length, about ready to erupt.

In view of the fact that the vibrissae are already well established on this fetus, far in advance of the guard hairs and underhairs, and on a body which has attained less than 1/200 of its newborn weight, one may deduce that the sensory bristles are very important to the welfare of the seal. Danforth $(1925$, p. 67$)$ has noted the remarkable constancy of vibrissae as compared with other body hairs of mammals, this "being due to their early appearance and the circumstances of their embryonic origin."

\section{Fetus of $103 \mathrm{~g}$. (0.021 MNW), female, 20 January}

Mystacial vibrissa formula : $0-3-4-5-5-3=20$ (plate 70-A). The outer (posterolateral) vibrissae in the row-of-four and in the row-offive are the longest, all about $4.6 \mathrm{~mm}$. All of the mystacial vibrissae are dark brown, almost black. "All but the smallest have whitish tips, 
suggesting that in the early stages of development the fiber starts to grow in advance of the melanoblasts. The superciliaries have now erupted and are distinctly unequal, the upper one of the pair meisuring $2.3 \mathrm{~mm}$. and the lower one $1.4 \mathrm{~mm}$. in length. They also are whitish at the tip.

\section{Fetus of $6.80 \mathrm{~kg}$. (1.3 MNW), male, $20 \mathrm{June}$}

This is a full-term fetus taken at sea on 20 June, actually larger than many newborn pups. The vibrissae are glistening black, with the barest suggestion of pale tips on several. The largest vibrissa is $64 \mathrm{~mm}$. in length, flattened, tapered, and slightly curved. (Vibrissae are the only fur-seal hairs that taper all the way from base to tip.) At the base, the cross section is elliptical and measures 0.39 by $0.55 \mathrm{~mm}$. Halfway along its length, at a point where the vibrissa will first fit into the slot of a Hardy sectioning device, the cross section is 0.28 by $0.33 \mathrm{~mm}$. (plate 69). The pigment is dark brown, cortical, and granular; mainly in clumps which increase in size and darkness toward the central axis of the fiber. Toward the periphery, pigmentation ceases rather abruptly, leaving a clear cortical zone about 5 microns wide, inside the cuticle. The surface of the vibrissa is smooth and without scale pattern. In cross section, the cuticle is seen as a hyaline layer less than 1 micron thick.

\section{POSTNATAL DEVELOPMENT OF THE VIBRISSAE}

Measurements of the longest vibrissa on each of 31 newborn seals are summarized as follows (table 4): 17 males, mean $62.6 \mathrm{~mm}$. (51 to 75$) ; 14$ females, mean $57.4 \mathrm{~mm}$. (52 to 63 ).

In both sexes, the vibrissae grow most rapidly in the juvenile and adolescent years, before the end of the third year. On a yearling male observed in Seattle Zoo during a 6-month period, February to $J$ uly, the longest vibrissa increased by $36.5 \mathrm{~mm}$., or at a rate of $0.20 \mathrm{~mm}$. a day. Here is evidence that growth of the vibrissa is not confined to autumn, as is growth of the pelage proper. On the same individual in its second year of life, between August and mid-April, the longest vibrissa increased by $32 \mathrm{~mm}$., or at a rate of $0.12 \mathrm{~mm}$. a day. The vibrissae are still growing at age 8 and, so far as the data permit one to estimate, will continue to grow throughout life (plate 70-B). The longest recorded vibrissa on a male is $334 \mathrm{~mm}$. (13.1 in.) and on a female $220 \mathrm{~mm}$. (8.66 in.). The record specimens were old animals of unknown age. The female was extremely largeweight $60.3 \mathrm{~kg}$. or $134 \mathrm{lb}$. Comparing the mean values for newborn pups with selected maximum values for adults, on the assumption that maximum values represent unbroken and relatively unworn bristles, one may estimate that the male vibrissa increases to about 5.3 times its newborn length; that of the female, 3.9 times. 
Changes in color of the vibrissae with advancing age have been studied with the objective of finding a useful age index. On St. Paul Island in September, I examined vibrissae of 20 freshly killed males, ranging in age from 4 to 6 weeks (estimated) to very old. On the black pup and the silver pup, all vibrissae are black (Munsell 7.5 YR 2/0). On the yearling and 2-year-old, many vibrissae are faded, grayish brown at the tip. On the 3- and 4-year-olds, the over-all color effect is blackish, though many vibrissae are mottled, most have faded tips, and a few of the small ones are all white. Through ages 5,6 , and 7 , the color is increasingly whitish, though a few small, all-black vibrissae may be seen. (The superciliary vibrissae gradually become worn down to, or broken off to, the level of the guard hairs, and one can seldom find them on a seal older than 6 years.) The single, very old bull examined had all-white mystacial vibrissae-actually pale yellow (2.5 Y 8/4). Paling of the base of the vibrissa begins when the pigment cells of the follicle cease to function. Paling of the tip is a result of fading (bleaching).

In this connection it is interesting to note a statement with regard to human hair which, like the vibrissa of the seal, is a nonmolting fiber: "The fact that in rare instances hair can quickly become gray must be acknowledged . . The old idea that hair is practically a dead tissue, cut off from the metabolic influences in the body, must be forsaken" (American Medical Association Journal, 1943, p. 162). Graying in man may result either from loss of pigment or from masking of pigment by gas bubbles in the cortex. Melanin can be bleached in vitro in the laboratory by ultraviolet radiation. Quite surely it can be bleached, though more slowly, by sunshine.

The color trend with age in the female vibrissae parallels that in the male (table 5). The 5-year-old (entering 6th year) exhibits the greatest variability in color. The vibrissae in about 67 percent of the 5-year female class can be called "black and white."

In July 1947, I saw mystacial vibrissae being plucked by native children from 3-and 4-year male seals on the killing fields of St. Paul Island (piate 71). One lad reported that he gathered about 500 a day and sold them for a cent apiece. The vibrissae were eventually delivered to an Oriental broker in San Francisco to be used (it is said) for cleaning the stems of pipes.

\section{Pelage Anomalies}

\section{COLOR ANOMALIES}

Three mutant color patterns have been observed in the fur seal: albino, piebald, and chocolate. 
The albino pup has white underhair, guard hair, and vibrissae (plates 72, 73-A, 73-B, 74). The parts that are black and naked on the normal pup (flippers, nose, and eyelids) are pinkish gray on the albino. The pelage becomes stained soon after birth. On a captive which had completed its first molt into adult-type pelage in the Seattle Zoo, the pelage on 2 December was reddish brown, or where brightest it was yellowish red (Munsell 5 YR 5/6) (plate 73-B). One rarely sees an albino older than a pup. Once or twice each summer a light-brown bachelor with pink eyes and flippers may appear in commercial sealing drives. A female albino lived to age 4 years in San Diego Zoo, while a fully adult female was shot in the wild in August (plate 74). With regard to incidence of albinism, Edward C. Johnston (in U.S. Bureau of Fisheries, 1923, p. 112) reported 6 white individuals in approximately 177,000 pups counted. Biologists on the Pribilofs now see perhaps 5 to 10 albinos each summer out of 500,000 to 600,000 pups born. Observed incidence of albinism is thus between 1 in 30,000 and 1 in 100,000. According to Green (1947) 6 albinos were reported in 1,672,604 coyotes Canis latrans taken over a 30-year period. This corresponds to 1 in 278,767 .

Piebald (white splotched) seals are seen more often than complete albinos (plate 75-A). One iris, neither, or both may be pinkish. White areas may appear on naked parts as well as on haired. A nearly full-term fetus had an unusual whitish belly, though the white was not sharply set off as it is on a true piebald. On one peculiar pup about 1 month old, the eyes and flippers were pink, the underhair white, but the guard hair grayish brown (plate 75-B). The character for pigment in guard hair is perhaps distinct from that for underhair; further study is needed.

The "chocolate" mutant is named from the appearance of the newborn pup. I cannot certainly identify in later life a seal that was chocolate at birth. Many variations of light brown, silver, and creamy pelage, combined with normal dark flippers and eyes, are seen on the breeding grounds (plate 76, $\mathrm{A}$ and $\mathrm{B}$ ).

\section{EFFECT OF DISEASES, PARASITES, AND PHYSIOLOGICAL DISORDERS ON PELAGE}

The terms "rubbed" and "mangy" are used loosely on the Pribilofs to describe pelage conditions where the hair fibers are sparse or patchy. Rubbed areas are seen on seals of all ages and both sexes. Wherever the guard hair is absent, the underfur becomes soiled and matted. Occasionally the underfur is also absent and the naked skin is exposed. Little study has been made of such pelage anomalies. Various degrees of "rub" or loss of guard hair are illustrated in plates 
77 (A and B) to 81. From the 6-year-old female illustrated in plate 77-B, samples of abnormal pelage were sent, in formalin and in dried state, to Dr. Robert W. Menges (U.S. Public Health Service); similar specimens were also sent from another 6-year-old female. Dr. Menges has kindly advised that no evidence of ringworm or mites can be found. The diagnosis in one case is "acquired canities" and in the other "atrophy of skin and alopecia" (personal correspondence, 1959). (See also Menges and Georg, 1957.)

On a male black pup perhaps 2 or 3 weeks old, patches on the back of the body and neck were hairless, wrinkled, pinkish gray, with marginal fragments of brown, scabby, loose epidermis (plate 82, $A$ and B). Seventeen lice were picked from ears, base of tail, eyelid, head, and denuded patches. It is presumed that the lice were scavengers on the denuded areas rather than causative agents in loss of the hair. While the lice in this case were not identified, two species have been collected frequently from fur seal pups: Antarctophthirus callorhini (Osborn) 1899, and Proechinophthirus fuctus (Ferris) 1916. Further study of the environmental preferences of the two species is proposed.

Murray (1958, pp. 404-405) kept lice from antarctic elephant seals Mirounga leonina under sea water for more than 2 weeks.

It would appear that oxygen is obtained from sea water by diffusion through the cuticle . . . Unlike other species of lice, Lepidophthirus macrorhini forces its way into the skin and creates a burrow under the stratum corneum of the epidermis ... When the elephant seal moults the stratum corneum . . . is shed intact with hairs attached. Although some lice are lost at this time many remain, since only the roof of the burrow which they inhabit is removed.

Pachyderma, or thick skin, was observed on a bachelor killed 3 July (plate 83). Tough, whitish connective tissue had replaced about nine-tenths of the blubber layer. The workman who tried to remove the blubber in routine fashion was obliged to reject the skin. The pelage was normal, the skin about five times thicker than normal. I am reminded of an ailment of cattle in which the hair is lost and the skin becomes thick, dry, leathery, and deeply creased (U.S. Department of Agriculture, 1954). This ailment, often fatal, is the result of contact with highly chlorinated napthalene in certain petroleum lubricants. Do seals suffer damage from prolonged contact with floating oil wastes on coastal waters?

Up to 1956, the skins of old female seals had not been taken deliberately on the Pribilof Islands. In 1956, substantial numbers were taken on an experimental basis. It was soon discovered that skins of old females tend to be of poor fur quality. Both underfur and guard-hair fibers may be uneven in length and insecurely rooted. 
As a result, the pelt after unhairing may present a ragged, splotchy appearance (plate 84). The causes-presumably physiological-of poor fur quality in older animals are unknown.

The damaging effect of high temperature on fur seass is well known to those who work in the sealskin industry. A seal driven too quickly from beach to killing field, especially on a dry, warm day $\left(60^{\circ} \mathrm{F}\right.$.), may die of heat prostration. Its pelt is subsequently called a "roadskin." "Temperatures of roadskin seals were between $42.3^{\circ}$ and $43.9^{\circ} \mathrm{C}$. . . Seals with temperatures above $42^{\circ} \mathrm{C}$. $\left(107.6^{\circ} \mathrm{F}\right.$.) are invariably prostrated or dead" (Ford Wilke and Karl W. Kenyon, in personal correspondence, 1951). Roadskin seals are flayed as soon as possible, because about an hour after death the fur fibers loosen in their follicles and can be plucked with one's fingers; the pelt is then worthless. Initial processing is accelerated in order to get roadskins into brine as quickly as possible in order to prevent loss of fur and hair.

Partridge (1938) studied horizontal layers sliced from fresh, shorn Alaska sealskins. He found that seals driven a long distance from the beach to the killing field tend to lose lipids from the "epidermal layer"-actually the epidermis and upper dermis-containing the sebaceous glands. He recorded percent lipids (of dry weight), as follows :

$\begin{array}{lrrrrrr} & \text { Seal No.t } & \text { Seal No. } & \text { Seal No.4 } & \text { Seal No.s } & \text { Seal No.5 } & \text { Seal No.6 } \\ \text { Length of drive. } & \text { short } & \text { short } & \text { short } & \text { long } & \text { long } & \text { (seal died) } \\ \text { Percent lipids_- } & 16.7 & 14.2 & 14.0 & 13.1 & 10.8 & 5.1\end{array}$

A fairly common, perhaps harmless, condition in which the blubber is reddish orange rather than white will be mentioned on page 60 .

From my diary in 1940 is taken a note on disease of the naked flipper :

During branding operations in September, we noted that several hundred pups had warty areas $1 / 8$ to $1 / 2$ inch in diameter on their flippers. These were of the same texture as the surrounding skin and were up to $1 / 8$ inch thick. Occasionally a flipper with a small, round, raw sore (originating in such a wart?) was seen.

Warts or blisters are commonly seen on older animals (plate 85).

Dr. W. J. Hadlow has written (personal correspondence, 1958), as follows:

On the basis of my limited examination of everal cutaneous nodules . . I I conclude that the lesion was formed from elements of the epidermal adnexa, probably from modified sebaceous glandular elements. The lesion somewhat resembled the general histologic pattern of the circumanal gland adenoma of the dog. A striking feature of the seal lesion was the presence of numerous large, acidophilic inclusions which occupied much of the cytoplasm of some cells. The nodules developed in the dermis and did not appear to involve directly the overlying epidermis, which usually was not appreciably altered. In this respect the lesions are not warts in the true sense of that term. 
Abegglen and others (1956, p. 14, 20) found strange circular marks on the fore flippers of approximately 50 bachelor seals in the summer of 1956. No satisfactory theory about the origin of the marks has been offered, although it is generally believed that they are natural rather than artificial. Raw, circular areas are occasionally seen on the fore flippers of seals taken at sea. These resemble Iamprey scars, though lampreys would not be likely to attack seals.

An abnormal bachelor was killed on St. George Island in 1949. The left flipper had apparently been bitten off in infancy, and the fur had grown over the stump so tightly that when the skin was blubbered no armhole was apparent on the left side. Biologists in 1947 tagged a pup with only one fore flipper. At the site of the missing flipper the pelage was intact and continuous. The pup moved successfully on land by "rock and roll."

Seals, particularly emaciated pups, are prone to suffer an eye infection which reveals itself as a purulent whitish or yellowish discharge. The disease has not been studied.

\section{EFFECT OF SEX ABNORMALITIES ON PELAGE}

Upon examination of five cryptorchids (adult males with infantile testes), it was concluded (Scheffer, 1951) that the pelage tends to be smooth in texture and uniform in color along the back, as on the adult female (plate 86). Mane and wig are conspicuously absent, as is the musky male odor of the body. One cryptorchid was discovered in a harem during breeding season. Its "unmaleness" led it to be treated as a female by the dominant male of the harem (plate 87-A). Its pelt is illustrated in plate 87-B. On another cryptorchid, estimated age 15 years, a normal brown layer of guard hair was present at the base of the flippers while underfur here was entirely lacking. The depth of guard hair on neck, back, and belly is less than the depth of corresponding guard hair on the normal adult male (table 3); the depth of underfur about the same. The length of mystacial vibrissae and length of ear are normal. On five cryptorchids, the maximum length of vibrissa was $286 \mathrm{~mm}$. (compare table 4). The maximum length of ear was $58 \mathrm{~mm}$. (compare maximum 57 mm. recorded for a normal male).

The finding (Scheffer, 1949) of a 4-year-old female with a prominent clitoris and small ovaries has been reported. The tanned pelt of this individual has no unusual features.

Supernumerary teats will be mentioned on page 53.

\section{FOREIGN GROWTHS}

Brown algae, red algae, and gooseneck barnacles are occasionally seen on the guard hair of living fur seals. Epiphytic green algae 
have been reported from phocid seals, though not yet from fur seals. Foreign growths are more common on seals at sea than on land. Why do organisms attach to certain individuals but not to others?

Brown algae, Phaeophyceae, Ectocarpus sp. (identified by Dr. G. F. Papenfuss) : On a female, 2 to 4 years old, nonpregnant, shot near Farallon Islands, California, 12 December 1948, the pelage appeared curly and brownish from an extensive growth of Ectocarpus (plate 88). The growth covered most of the body except nose, flippers, and belly; the parts that are commonly rubbed during grooming activities at sea. Fragments of the dried plant, light brown in color, remained on the pelt throughout the tanning process.

Red algae, Rhodophyceae, Erythrocladia sp. ("if not identical with the species, is closely related to E. polystromatica Dangeard" Papenfuss, personal correspondence, 1945) : This plant is of fairly common occurrence on seals. It gives a rusty, reddish brown tint to the guard hair. Under a microscope, it has an attractive purplish color and is seen to be made up of dense clusters or disks closely appressed to the hairs. The first specimen from a fur seal was collected on a bachelor seal on St. Paul Island on 2 August 1945. Three similar collections made 22 June-3 August 1946 were identified by Papenfuss as Erythrocladia (polystromatica?).

Barnacles, Cirripedia, Lepas sp. (identified by Dr. Dora P. Henry) : Gooseneck barnacles are seen on perhaps one fur seal in a hundred taken at sea ; rarely on land. A bachelor killed on St. Paul Island, 18 July 1945, had several hundred barnacles $L$. hillii Leach attached to the rump (plate 89).

An emaciated yearling female, weighing only $6.4 \mathrm{~kg}$. (14 lb.) was found dead, in fresh condition, near Grayland, Wash., on 11 April 1948. Several hundred barnacles were attached in clusters to the armpits, hind flippers, fore flippers (base only), and belly. An adult female, weight $26 \mathrm{~kg}$. (58 lb.) was found dead in the surf near Cape Shoalwater, Wash., on 27 April 1948. Tufts of barnacles were attached to the armpits. Dr. Henry wrote (personal correspondence) "The yearling female has young Lepas and larvae; the adult has larvae only." The female mentioned previously as having Ectocarpus growth had also gooseneck barnacles scattered over the body.

\section{The Pribilof Sealskin Industry}

\section{HISTORY OF THE INDUSTRY}

The Pribilof seal herd has been cropped annually, so far as anyone knows, since the discovery of the breeding grounds in 1786-87. Modern, sustained-yield management began with the Treaty of 1911, 
at which time all northern fur seals were brought under international protection and the killing of Pribilof seals was undertaken directly by employees of the United States Government. The Government now has an interest in all stages of the industry, namely, management of the stock, cropping, processing, and marketing. The stages after killing are handled primarily by a private contractor under Government supervision (Baker, 1957; Fouke Fur Company, 1958; Scheffer and Kenyon, 1952; Thompson, 1950).

Previous to 1855 fur-seal skins were in little demand in Europe or America. The fur was not fashionable ... Abont 1825 the unhairing and dyeing of furseal was introduced [by Denison Williams, a capmaker of Albany, N.Y.], and although the article was very poor compared with the choice product of the present time, it was a decided advantage over the former methods of dressing. Between 1855 and 1870, through experiments on the part of Messrs. Oppenheim \& Co., and of Messrs. Martin \& Teichman, in London, and of Mr. George C. Treadwell, in Albany, the methods of dressing and dyeing fur-seal were greatly improved, resulting in an exquisitely soft and downy texture and rich darkbrown color, which was quickly adopted by the fashionable world for cloaks, jackets, muffe, trimmings, etc. So popular did the fur become that the demand quickly ran up . . . to 200,000 during the eighties at greatly increased prices ... Since 1870 practically the entire world's product of fur-seal skins has been sold in London. [Stevenson, 1904, p. 300-301]

No Pribilof sealskins owned by the United States Government were shipped to London for processing or sale after 1912. On 16 December 1913, the Government began selling sealskins at public auction in St. Louis, Mo. During World War I, with encouragement from the Secretary of Commerce, the Gibbins and Lohn Fur Skin Dressing and Dyeing Company developed a factory in St. Louis for processing sealskins. The early success of the company was partly the result of skills brought directly from London by Messrs. Gibbins and Lohn. The first lot, including 1,900 dyed pelts, was sold on 20 September 1916 in St. Louis by Funsten Brothers and Company. Early in the year 1921, the Grovernment contract with Funsten was canceled and a new one entered into with the Fouke Fur Company. Down to the present time, this firm has been the sole contractor for handling the United States' share of pelts from the Pribilof Islands (Fortune, 1930; Fouke, 1949; Fur Trade Review, 1916; U.S. Bureau of Fisheries, 1916, 1917, 1922, 1938).

\section{KILLING, SKINNING, BLUBBERING, AND CURING}

The "island operations" have been described by many authors (see above). Since about 1940 the annual harvest has consisted almost entirely of bachelor seals: 60,000 to 70,000 subadult males near the end of their third or fourth year of life. Since 1956 the harvest has also included a substantial number of females, from subadult to old- 
adult. Future plans call for a sustained annual harvest of both males and females.

On the killing field, the seal is clubbed on the head and the pelt is stripped from the body, along with adhering masses of blubber and other subcutaneous tissues. The raw pelt is washed overnight in running sea water. On the following day, the blubber is removed forcibly with a dull blubbering knife, and the tail, ears, and loose tatters of skin are trimmed off (plates 90-92). The pelt is then washed for 12 hours or more in circulating saturated brine, wrung, dusted with boric acid and salt, barreled, and shipped to St. Louis.

A kind of spoilage, known as "pink," on the leather side of cured sealskins was seen from time to time in the early years of the industry. It was produced by halophilie bacteria, certain ones of which are able to live in saturated brine. Spoilage is now controlled by dusting each skin with boric acid before it is shipped. ZoBell (1946, p. 196-197) has given a good review of spoilage in sealskins and other marine products.

\section{PROCESSING AND MARKETING}

A sealskin shipped from the Pribilofs may not reach the auction block as a finished pelt for a year or two. The raw, salted skin is held in cold storage in the original barrel until the factory is ready to work it. There are more than 125 different operations in the Fouke process, and it takes more than 3 months for the completion of the dressing and dyeing of each skin, which is in work continuously (Fouke Fur Company, 1958, p. 45-46). Processing includes four main steps: unhairing, leathering, dyeing, and finishing.

The raw, salted skin is first graded for size (essentially length and width) on a set of five graduated wooden boards, the prototypes of which came from London before 1916 (fig. 2 and table 6). As a result, each skin can then be processed with others of its size, all of them receiving, for example, the same measured amount of detergent. The five size-grades are small medium, medium, large, extra large, and extra extra large. In actual practice, the raw pelt is first graded as small, medium, or large. The "large" lot is again graded into large, extra large, and extra extra large as a matter of record and for possible research use. The three divisions of "large" are then regrouped for processing.

Also at this time a particular blemish or undesirable feature may be noted in the record, for example, bite, bruise, scar, or flay. The location of the blemish may be charted on a special card (fig. 3).

The next important step is unhairing. The skin is quickly and carefully preheated in a "cockle." It is then placed over a beam, dusted with chalk, and the guard hairs are scraped off with a tool 


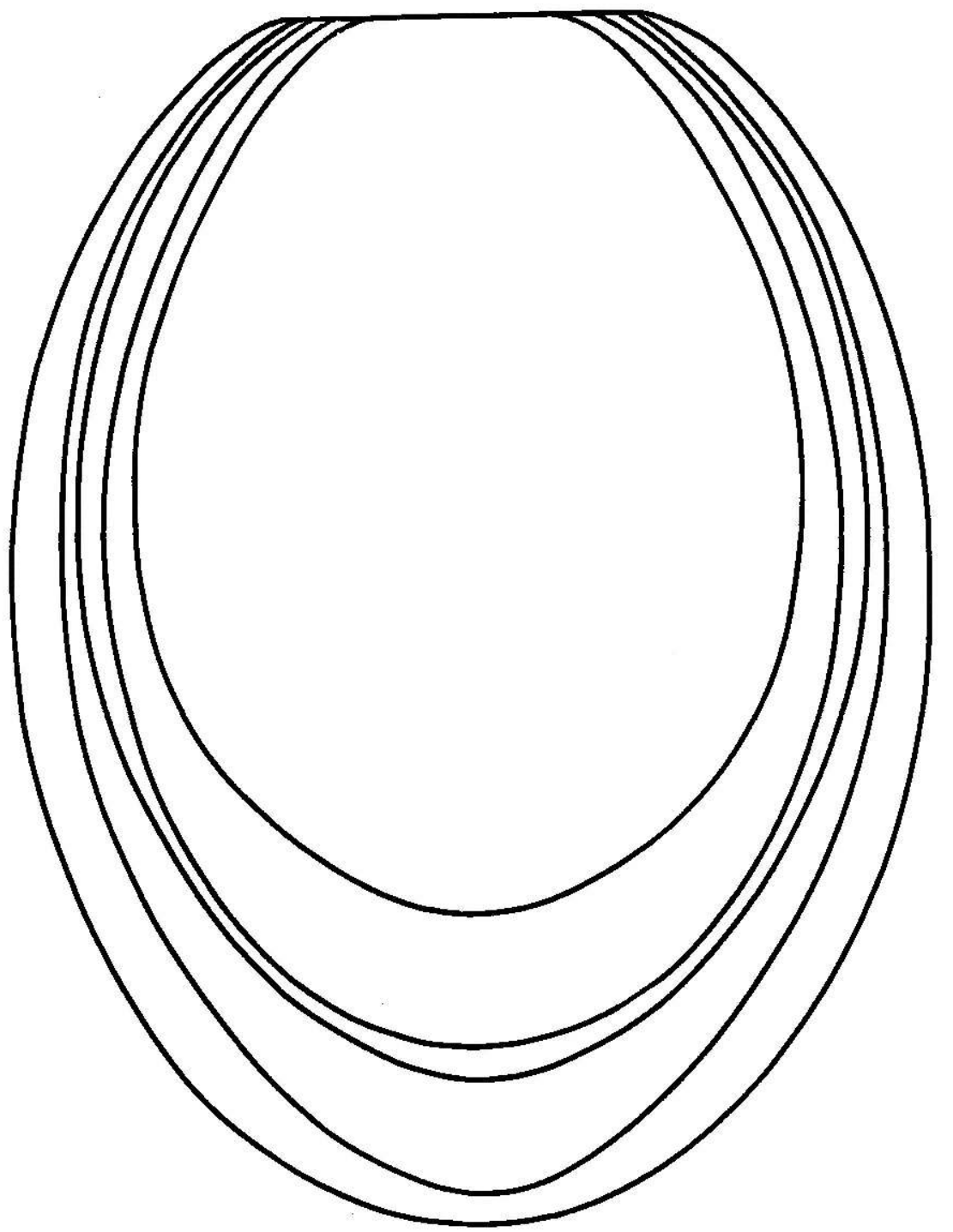

Froure 2.-Outlines of the five boards used for size-grading raw, salted sealskins; $\times 1 / 8$ (see table 6). 


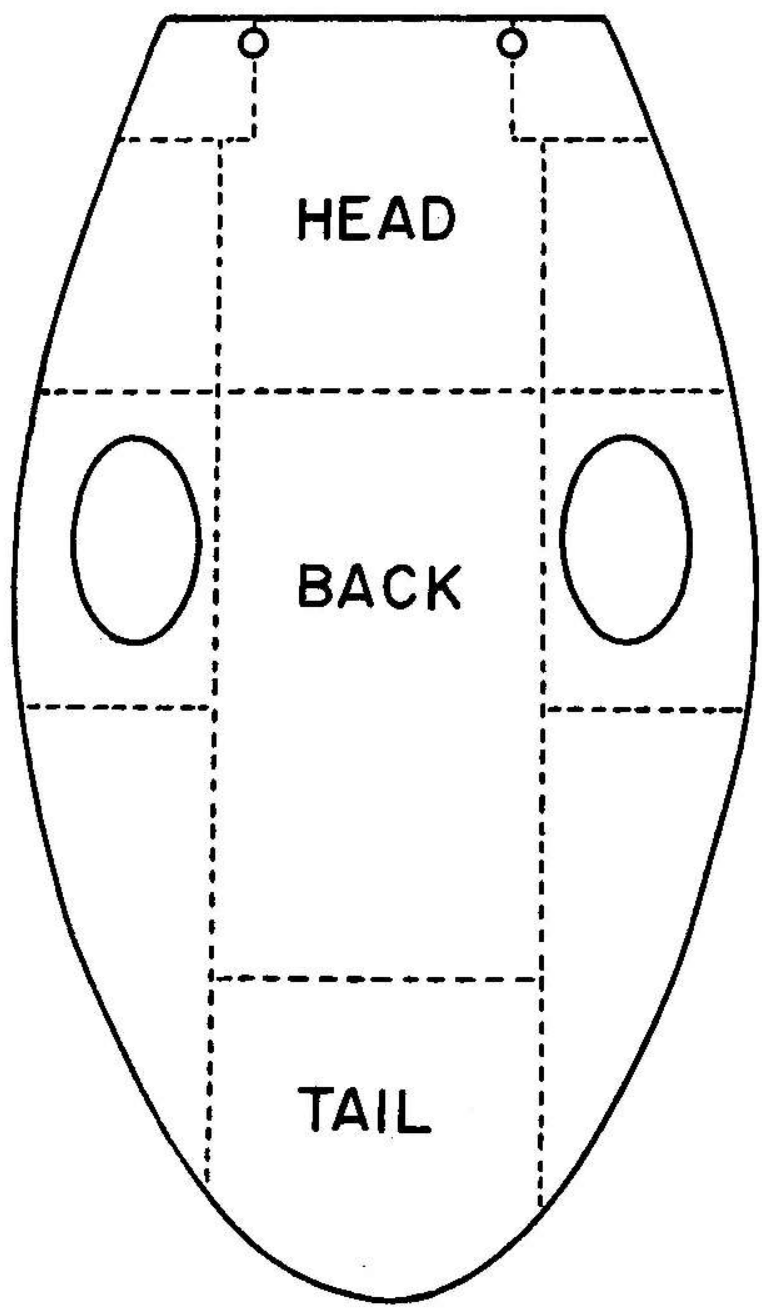

Fraurg 3.-A sealskin "map" used for reference purposes in technological research. On a finished, dyed, and trimmed sealskin, the small circles represent ear holes; the large ovals, fore flipper boles. 
similar to a blubbering knife. At a much later stage in processing, the skin is passed through a "dehairing" machine which clips off the shorter, residual guard hairs. Poland (1892, p. 191-192) referred to these as "water-hairs" and described a machine for clipping them; basically the same machine is in use today.

Leathering of the sealskin is essentially an oil, or chamois, dressing. A chemical pretanning is not applied. The oil is derived from seal blubber which has cured for months in salt. Mathur (1927) found that this oil contains up to 7 percent free fatty acids. He concluded that oil tannage is essentially a process in which, through the action of free fatty acids (particularly oleic series), water is removed from the skin but connective tissue fibers are left intact. Oil tannage seems to be irreversible, in distinction to tannage by chrome, vegetable, or alum.

The dyeing process is, to a certain extent, a trade secret. Various inorganic and organic reagents, as well as complex vegetable and animal pigments, are used to produce black, brown, and gray tones in the underfur. The natural curl of the fur is removed, though a bend or kink remains near the base of each fiber.

The finished pelt is graded for length on boards which are ruled in one dimension only. However, the grading is not altogether objective, and a very narrow skin (for example) would be graded slightly shorter than its actual length. The same terms-small medium to extra extra large--as were applied to raw, salted skins are applied to the finished pelt. The finished pelt is also graded for quality, under a system long established, as follows :

Regular : fine, one (I), and two (II)

Scarred : A (same as fine and one, but scarred), and B (same as two, but scarred).

Three: (damaged, off-size, or very poor quality fur, virtually unsalable).

The pelts are sold at twice-yearly auctions in St. Louis for the account of the Government.

\section{DIMENSIONS AND WEIGHTS OF SEALSKINS}

For their practical value, certain data have been assembled on the sizes of sealskins at various stages in the routine flow from killing field to auction block. These are presented below

The question had been raised "For seals of any specified length, do those individuals with greater girth tend to arrive earlier on the breeding ground?" Data provided by the Fouke Fur Company for the period 1938-41 are given in tables 7 and 8 and are compared graphically in figure 4 . These data show that the proportion of larger skins taken before mid-July is approximately the same as the proportion taken after. (In accepting this interpretation, one must 


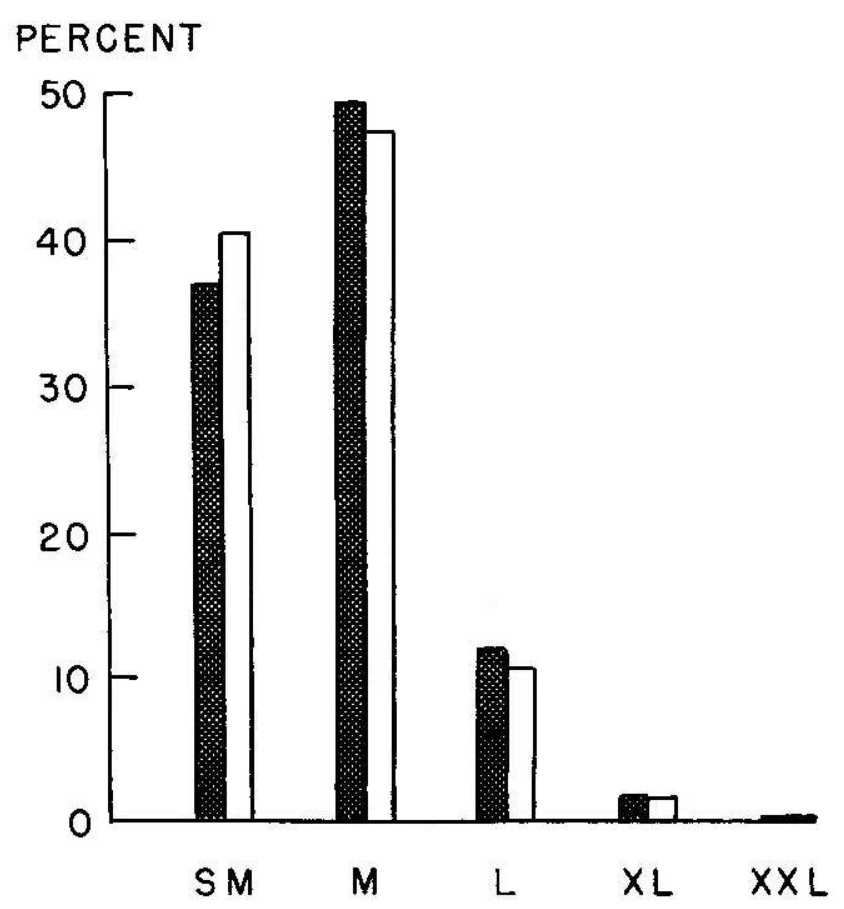

Frgure 4.-Comparison of sizes of male sealskins taken in early season and late season. Shaded column = early season; unshaded $=$ late. Data from bottom row in tables 7 and 8 ; based on 105,249 skins taken in early season and 84,277 taken in late season.

assume that seals of comparable length are killed each year. This is a reasonable assumption, in view of the fact that only seals measuring between certain established length-limits are taken by the killing crew.) In 1949 , an answer to the same question was sought by other means. During a 41-day period, 17 June-27 July, 558 bachelor skins were segregated according to field length of seal. The range in length was 38 to 51 inches. Each skin was weighed in freshly blubbered and wrung condition, without mask and flippers. The observed weights did not change appreciably, within a length class, from early to late season. The mean weights for the 558 skins are (pounds) : first quarter, 5.4; second quarter, 5.3 ; third quarter, 5.5; fourth quarter, 5.1; mean for season, 5.3.

In the foregoing paragraph $I$ have shown that, for bachelors at least, the skin areas and skin weights of early-season individuals are no greater than those of late-season individuals. Now attention is called to table 9 , in which the whole body weights of 
early and late arriving females of known age are given. Here the conclusion is inescapable that the earlier individuals, within an age class, are heavier. The conclusions drawn in the two paragraphs are, of course, not incompatible.

Relation between field length of the bachelor seal and weight of the fresh pelt is shown in table 10 and figure 5. The greatest variation in skin weight is exhibited in the 44-inch animal. Seals with a field length of 44 inches represent 3- and 4-year-olds in almost equal numbers. Greatest variation in body size is commonly exhibited during the years of adolescence in fur seals as well as other mammals. Scheffer (1950 d, p. 388) found the highest coefficient of variation in weight of fur seal testes in ages 3 and 4 .

Relations between field length of bachelor seal and size classification of skin in raw-salted and in finished condition are shown in tables 11 and 12 and in figures 6 and 7 .

An attempt to translate a given trade classification, such as "small medium," into dimensions of skin by inches has been made in tables 13 and 14. (The shape and size of the grading board has previously

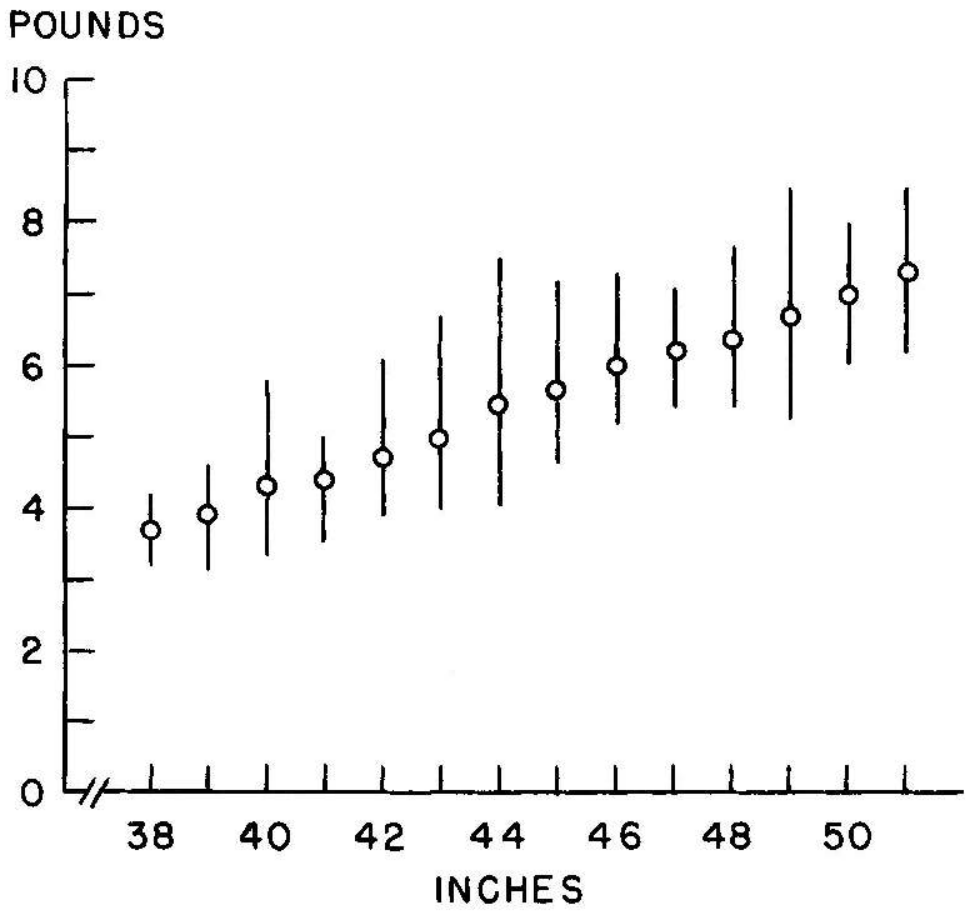

Frauke 5.-Weight of fresh male sealskin with relation to field length of seal. (Data from table 10; vertical lines $=$ range, circle $=$ mean.) 
PERCENT

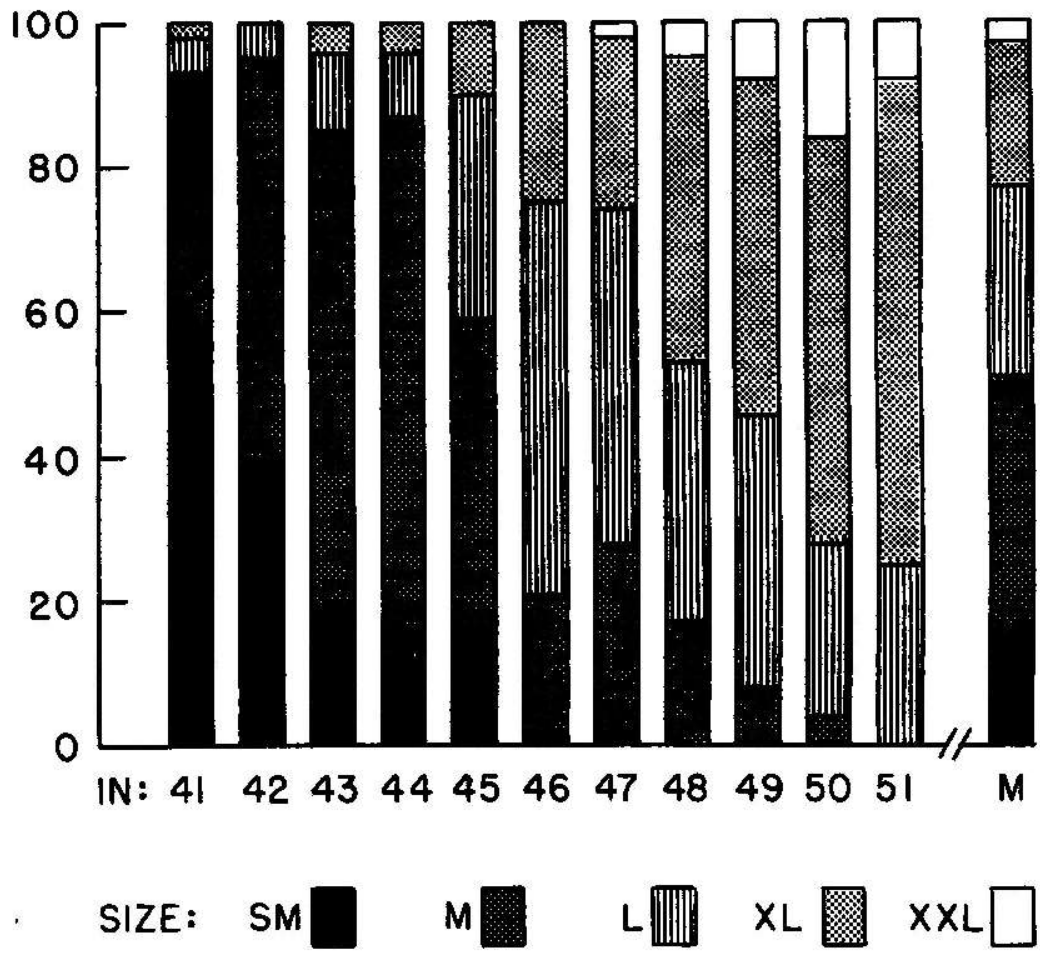

Frauke 6.-Trade classiflcation of raw, salted male sealskin with relation to fleld length of seal. (The "field length" in inches, smout to tip of tail on unskinned animal, was obtained from 523 subadult male seals, mostly ages 3 and 4 years, sampled at random between 18 June and 20 July 1946, on St. Paul Island. The fate of the pelt from each seal was followed through processing by the Fouke Fur Company. About one year after the kll, each pelt was classifled in raw, salted condition according to trade size, that is : small medium, medium, large, extra large, or extra extra large. In the present figure, the left-hand column (for example) shows that, of all 41-inch seals sampled, $57 \%$ produced a small medium pelt, $36 \%$ medium, $5 \%$ large, and $2 \%$ extra large.)

been mentioned.) The length limits given in table 14 do not entirely agree with those given by Bachrach $(1946$, p. 520). His limits are: small medium, below $381 / 2$ inches; medium, $381 / 2$ to $421 / 2$; large, $421 / 2$ to $451 / 2$; extra large, $451 / 2$ to $481 / 2$; extra extra large, $481 / 2$ to 55 ; and wigs, over 55 .

In 1956 the Government began for the first time to take female seals in substantial numbers as part of a long-term plan. In that year, there were taken 22,680 females by 15 August and 26,884 
PERCENT
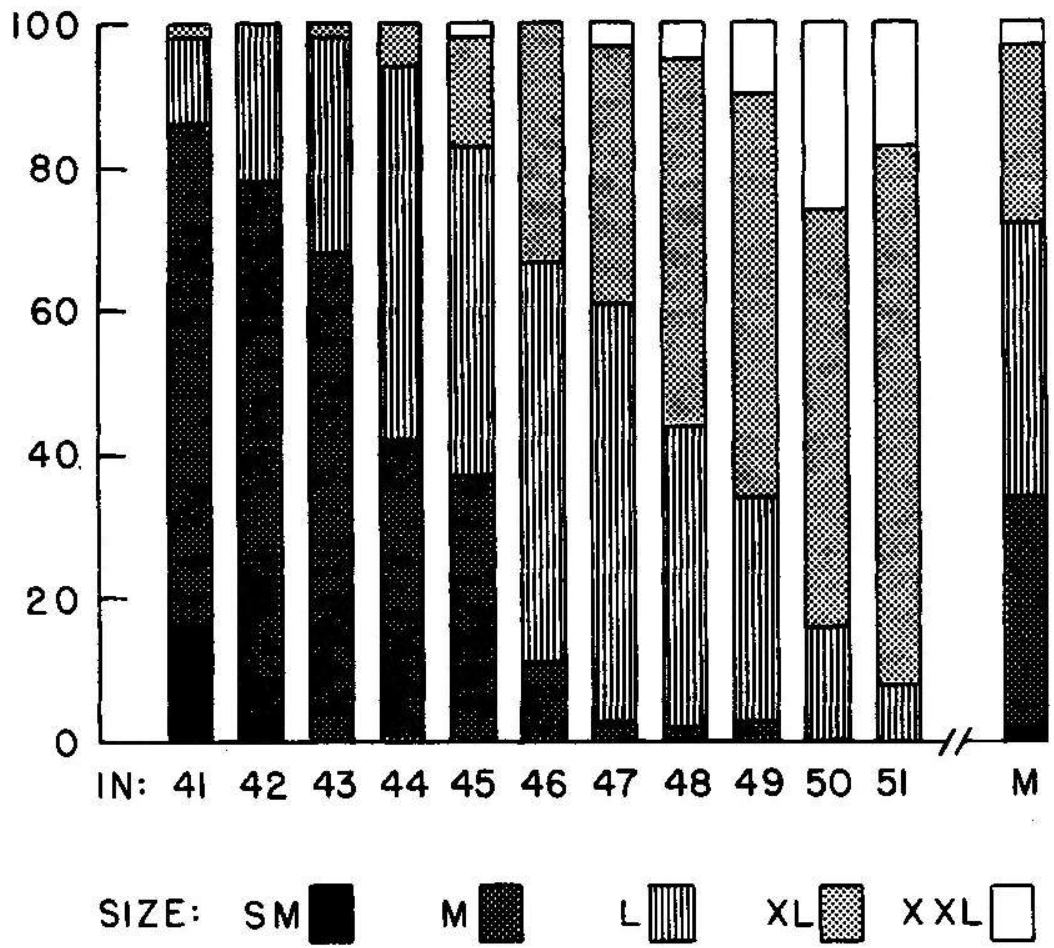

FreURe 7.-Trade classiffcation of finished, dyed male sealskin with relation to field length of seal. (For explanation see fig. 6.)

females by 8 September. Quantitative data on female skins (size, weight, relation to field length and trade classification) will not be available for several years. Skins taken from old females in the 1956 and 1957 seasons were generally of poor quality, with fur sparse and uneven in length on back of neck and belly (plate 84). As compared with bachelor skins, the female skins were said to be more elastic. During the period 4-8 September 1956, a tally was kept of female pelts rejected from the kill as being commercially unattractive. Out of 4,807 females killed, the pelts of 603 , or 12.5 percent, were rejected (Abegglen and others, 1956, tables $\mathrm{S}$ and $\mathrm{T}$ ). All age-classes from 2 to 10-plus were included, though about half of the seals killed were in classes 2 to 5 years. While admitting that the skins of old females killed in August may be difficult to process, I am inclined to believe that part of the difficulty stems from the fact that routine 
processing methods are being applied to a new and unusual class of skin. (See also discussion of molt on page $26 \mathrm{fff}$.)

The weights of tanned pelts in the National Museum collection3 adult males and 4 adult females-indicate that the male pelt without flippers may weigh up to 10 pounds; the female pelt without flippers, up to 4 pounds. These pelts were prepared for study, not for commercial use.

\section{STRENGTH AND DURABILITY OF SEALSKINS}

Bowker (1931) measured the strength and thickness of commercial sealskins dyed black or brown. Although not so specified, the skins were certainly those of bachelors (3- or 4-year males), buffed in the routine way. Results: thickness, 0.023 to 0.026 inches; breaking strength of a half-inch strip, 37.5 to 46.0 pounds; tensile strength, 3,150 to 3,680 pounds per square inch; percent stretch at failure, 23.5 to 38.1 ; stitch-tear, 6.1 to 9.3 pounds. Sealskin leather, though slightly weaker, compares favorably with the leather of light calfskin and sheepskin.

Terao (190) examined the leather of sharks, moray, California sea lion, common dolphin, sperm whale, and blue whale.

The fibrous matter of the leather was found mostly running obliquely longitudinally and united with transversely directed one so that it forms an irregularly shaped rhombic network. The general feature of the network is evident in the configuration of the upper-surface which is so characteristic to each species as to aid its identification . . . The findings stand in harmony with the fact that the leathers of aquatic animals are liable to be torn transversely when used as boots, bags, ete.

L. A. Hausman, who studied for many years the microscopy of hair, published $(1939$, p. 503) a table showing "durability" of commercial furs. He ranked highest those species having fur hairs with little or no medulla, as follows: Grade 100, otter and wolverine; grade 90 , beaver; grade 80 , fur seal; grade 70, skunk and mink; grade 65 , raccoon (natural) ; grade 50, raccoon (dyed) ; grade 45, muskrat; grade 40, fox (natural) ; grade 35, oppossum; grade 25, fox (dyed), ermine, nutria, and lynx; grade 15, chinchilla and goat; grade 5, rabbit, hare, and mole. 


\section{OTHER FEATURES OF THE SURFACE TOPOGRAPHY}

\section{Features of the Head}

\section{NOSTRILS, MOUTH, AND LIPS}

These features have been examined on four selected fetuses, and on newborn and adult seals, as indicated below. ("MNW"=mean newborn weight; see page 10.)

\section{Fetus of $23.7 \mathrm{~g}$. (0.0049 MNW), female, 14 February}

The nostrils are slightly open; mouth open and tongue showing.

Fetus of $103 \mathrm{~g}$. (0.021 MNW), female, 20 January

Nostrils and mouth are open (plate 70-A).

Fetus of $1.42 \mathrm{~kg}$. (0.26 MNW), male, 22 March

Between the parted lips, 20 low, softly rounded bumps along the gumline show where most of the teeth will appear. On each side of the mouth there are 4 bumps above and 6 bumps below.

\section{Fetus of $3.31 \mathrm{~kg}$. (0.69 MNW), female, $6 \mathrm{July}$}

On each side of the mouth the tips of the following teeth have erupted: (above) 3 incisors, 1 canine, and 3 cheek teeth; (below) 2 incisors, 1 canine, and 2 cheek teeth; a total of 12 . The third lower cheek tooth, which will complete the deciduous set, has yet to appear.

On newborn and older seals, the rhinarium and nostrils are dark gray, near black (plate 98-A). The dark color continues into the tunnel of the nares as far as one can see, or 1-3 cm., depending on the size of the seal. The upper and lower lips are medium gray. The mouth and tongue are flesh pink, becoming red in an overheated individual and fading to dirty grayish pink after death (plates 55 and 98-B).

The tip of the tongue has a curious notch, 4 or $5 \mathrm{~mm}$. deep in adults - a feature of all pinnipeds except the walrus.

\section{EYELIDS, EYE GLANDS, AND IRIS}

The eyelids are open on a fetus of $822 \mathrm{~g}$. (0.17 MNW), female, 9 March, and on all larger fetuses (plates $34,36,41-\mathbf{A}, 52-\mathbf{A}$, and 55). 
The eyelids are closed on smaller specimens. On newborn to adult seals, the eyelids are streamlined. Each is a low-relief extension of the facial coat; thick, muscular, and hairy (plate 99). Wide open, it frames a nearly circular aperture and is rimmed (in the newborn) by a 2- to 4-mm. wide band of naked, black, thick, wrinkled skin. The diameter of the eye opening is about $11 \mathrm{~mm}$. in the newborn and 20 $\mathrm{mm}$. in the adult.

Pinnipeds have tear glands but no ducts leading to the nasal passage. According to Rabsch (1953, p. 488) the lachrymal gland is small, the Harderian gland large, and the individual fornix glands especially well developed. Alaska fur seals "cry" freely in warm, dry weather; the tears run down the cheeks (plate 100).

The iris of the eye is dull bluish gray when the fetal eyelids open for the first time. It is black or brownish black at birth, and thereafter. The eyeballs of two 4-year-old males are $43 \mathrm{~mm}$. and $46 \mathrm{~mm}$. in diameter.

\section{EARS}

On a fetus as small as 23.7 g. (0.0049 MNW), female, 14 February, the ears are well formed and nearly adult in shape. A groove or flexure persists for 4 to 6 weeks around the base of each ear. In a fetus of $1.11 \mathrm{~kg}$. ( $0.23 \mathrm{MNW})$, female, $23 \mathrm{March}$, the groove is beginning to disappear and the ear pinna is becoming more cylindroid and stiffer (compare plate 101-A; also plates 34,36 and $41-\mathbf{A}$ ). Thus, the ear is becoming more like that of a pinniped and less like that of a land carnivore.

On an adult seal, the inside of the ear pinna, which can only be seen when the furled edges are pried apart, is smoky grayish brown, smooth and glossy (plates 52-A, 55, and 101-B). Externally, from the base toward the tip, the fur disappears and the overhairs become shorter, more slender, sparser, and lighter in color. The epidermis of the outer surface of the ear is black. The blackness is conspicuous at the tip and along the distal third of the ear, where the original fine hairs have been lost through abrasion. The pelage beneath and just behind the ear is paler than the surrounding hair. (Description of an old female; additional notes on the pelage of the ear were given in the preceding chapter.)

On the evidence of 201 measurements (table 15), the growth in length of the ear has virtually ceased by the eighth year of life. Growth during postnatal life represents an increase of about 35 percent in males and 30 percent in females. 


\section{Features of the Belly}

\section{MAMMARY GLAND COMPLEX}

The teats or nipples on the skin of the female and male will be described first, then the mammary glands of the female. On a female fetus of $23.7 \mathrm{~g}$. (0.0049 MNW), 14 February, the position of each of the four mammary teats can clearly be seen as a white dot beneath the surface of the skin. Each dot eventually becomes a pimple, then a pimple within a dimple (plate 36 ). Vellus of the belly grows up around the circular, naked, flesh pink dimple. On a living, full-term fetus of $3.31 \mathrm{~kg}$. ( $0.69 \mathrm{MNW})$, female, $6 \mathrm{July}$, the anterior teats are $70 \mathrm{~mm}$. apart, on a line $58 \mathrm{~mm}$. anterior to the navel; the posterior teats are $43 \mathrm{~mm}$. apart on a line $26 \mathrm{~mm}$. posterior to the navel. Each teat is hidden in the pelage, though its location is marked by a light gray dot of hair. None of the teats on the female has, at time of birth, risen above the black hairy coat of the belly. The anterior and posterior pairs of teats develop at the same rate and seem to be equally important throughout life. On no fetus is there evidence of rudimentary (vestigial) teats.

The teats become more conspicuous with advancing age. On a silver pup as well as on older, but not yet parous, individuals, the teat locations are indicated by faint brown spots. Occasionally they can be found only after the guard hairs have been parted with one's fingers. They are conspicuous, dark brown spots on the pelage of parous females, both in and out of the nursing season (plates 102 and $103, A$ and B). On a fully adult, lactating female, the loose, blackish, wrinkled, naked teats can be stretched with one's fingers to a length of $25 \mathrm{~mm}$. On a large old female, the teats were arranged as follows: 2 lying $20 \mathrm{~cm}$. apart on a line $25 \mathrm{~cm}$. anterior to the navel and 2 lying $9 \mathrm{~cm}$. apart on a line $6 \mathrm{~cm}$. posterior to the navel. It has been found that the measured distance between levels of anterior and posterior teats on the tanned pelt is worthless as a criterion of age. For example, this distance on a silver pup, length $76 \mathrm{~cm}$., is the same as on an 8-year-old, length $125 \mathrm{~cm}$.

Of the tanned skins of $\mathbf{4 0}$ females examined with special attention to the mammary teats, 2 have an extra (fifth) teat. On the pelt of a 5 -year-old, there are 2 posterior teats on the left side, $10 \mathrm{~cm}$. apart, aligned with the long axis of the body. On a 10-year-old, there are 2 posterior teats on the right side, $11 \mathrm{~cm}$. apart, similarly aligned. A 10 -year-old examined in the field was noted as having " 5 nipples in use."

On the male fur seal, the 4 teats are always hidden by the pelage. They are arranged around the navel as on the female (plate 104). On a fresh carcass of a 6-year-old, the teats were arranged as follows: 
2 lying $19 \mathrm{~cm}$. apart on a line $20 \mathrm{~cm}$. anterior to the navel and 2 lying $10 \mathrm{~cm}$. apart on a line $4 \mathrm{~cm}$. posterior to the navel, $12 \mathrm{~cm}$. anterior to the penial opening. One can occasionally locate the male teats by finding faint brownish or blackish spots on the pelage, though more often one must wait until the pelt has been removed and tanned; then search for scarlike marks on the leather side (plate 105).

On plucked pelts of both sexes, the location of the mammary teat is marked by a slight break or depression in the fur surface. Here the color is uniform light brown, like the surroundings.

With the hope of finding a relation between the underlying mammary glands and the sparse, often patchy underfur of the belly, in September $1958 \mathrm{I}$ examined the glands on a number of fresh carcasses. The gland-complex proves to be an extensive apron covering the lower thorax, abdomen, and sides of the body. The sketch reproduced in figure 8 is based mainly on dissection, with photographs, of an old female, age over 10 years, not lactating, killed on 9 September (plate 106-A). It is also based on cursory field dissection of 4 copiously lactating individuals. In the old female specimen, 2 liters of embalming fluid were introduced through the 4 teats.

Using a knife, one can easily separate the glandular tissue from the overlying blubber. The glandular tissue is light brown and more fibrous; the blubber is whitish and less fibrous (plate 106-B). The blubber at the level of the anterior teats is $2 \mathrm{~cm}$. thick; the glandular tissue is 1 to $2 \mathrm{~cm}$. thick. These two layers are, at the level of the posterior teats, $2 \mathrm{~cm}$. and 1 to $1.5 \mathrm{~cm}$., respectively. On the old female, length $137 \mathrm{~cm}$., the gland-complex is about $66 \mathrm{~cm}$. long and $50 \mathrm{~cm}$. wide, along curves of the body. Posterior to the armpits the gland bends rather abruptly upward along the sides; anterior to the heels it bends less abruptly upward. It reaches forward about $21 \mathrm{~cm}$. beyond the level of the anterior teats or almost to the level of the insertion of the fore flippers. It reaches hindward about $20 \mathrm{~cm}$. beyond the posterior teats, or almost to the level of the heels. Its total area is $2,189 \mathrm{sq}$. cm. (339 sq. in.). The gland-complex appears to be one continuous sheet, though it probably consists of 4 anastomosing units, 1 unit draining into each teat. (When embalming fluid was injected, the region around each teat swelled independently.) The main duct leading to the teat is thin-walled, about $5 \mathrm{~mm}$. in diameter, and is conspicuous for only $6 \mathrm{~cm}$. of its length, the deeper portion being buried in glandular tissue. The shape of the milk reservoir beneath each teat is suggested in plate 106-A. At its margin, the glandcomplex becomes very thin, not over 2 or $3 \mathrm{~mm}$. A shipbuilder would say that it is "faired" into the body. Carlisle (1954) believes that mammary glands may have originated from sebaceous glands, rather than sweat glands. 


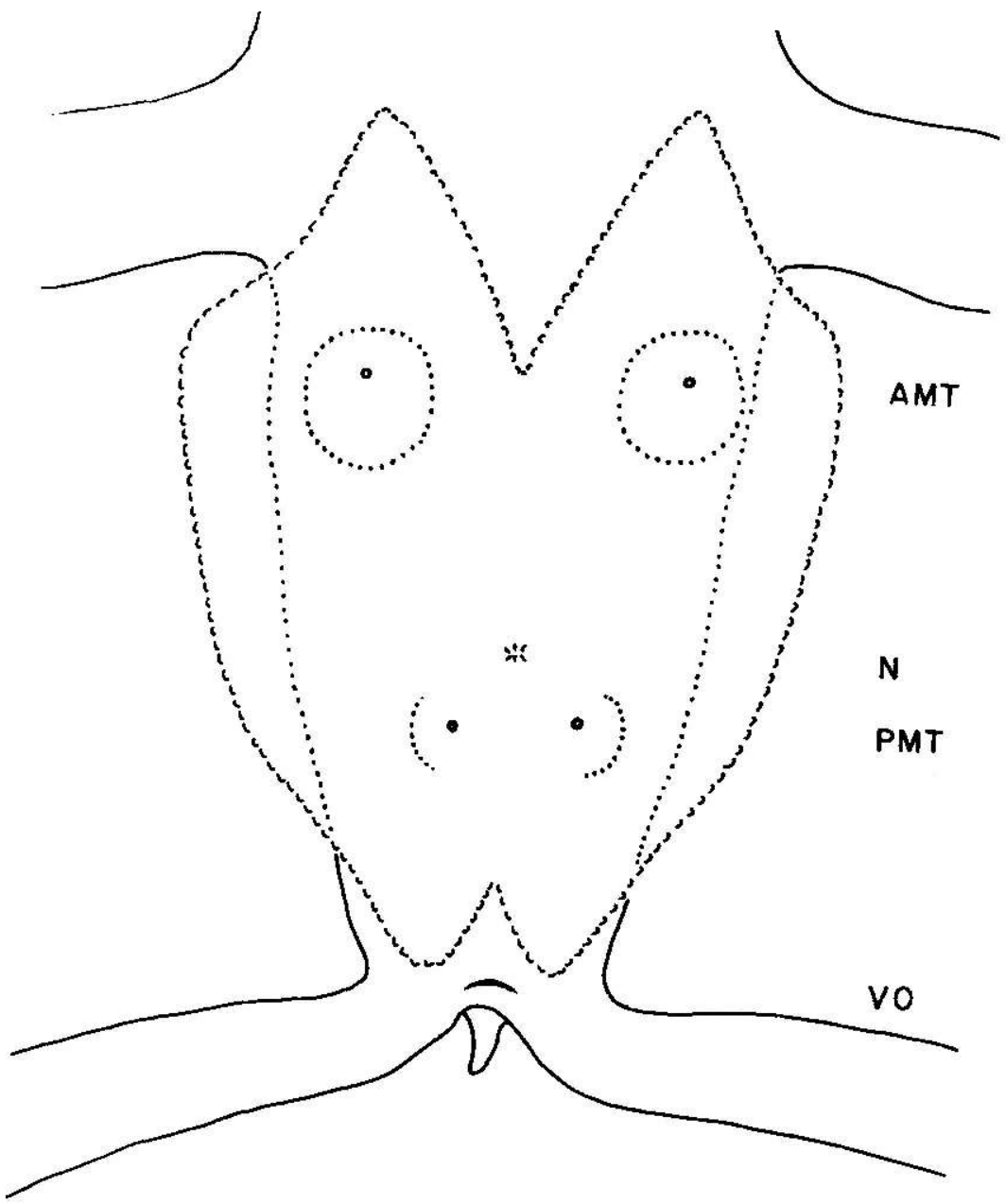

FIGURE 8.-Diagram of the mammary gland complex; represented on a flat surface with the side flaps lifted to the plane of the thorax and belly; reservoir beneath each teat swollen with embalming fluid; distance between anterior teats $24 \mathrm{~cm}$.; letters represent anterior mammary teats, navel, posterior mammary teats, and vaginal opening. 
Milk capacity of the mammary gland is perhaps 2 or 3 liters. Milk in the bulging stomach of a nursling has been found to vary in amount from 1 liter in a newborn to 2.5 liters in a pup nearly weaned (Scheffer, 1950 c, p. 7 ; and Ford Wilke, MS, 1941, based on specimen BDM 6). To a limited extent, milk may flow spontaneously from the mother. On 27 September the writer saw a cow of medium size scrambling over the rocks in alarm. Five to ten drops of milk fell in rapid succession from her left anterior teat. Wilke collected milk as it drained from the slashed mammary gland of a female in estrus; he later reported (1959) that it contained 46 percent fat.

(The milk of the gray seal Halichoerus may contain up to 53 percent fat, while the suckling elephant seal Mirounga may quadruple in weight in 21 days!)

\section{PENIAL OPENING AND SCROTUM}

On the smallest male fetus available for study, $131 \mathrm{~g}$. (0.024 MNW), 25 January, the site of the future penial opening is a distinct dimple about $0.5 \mathrm{~mm}$. in diameter. On a fetus of $2.21 \mathrm{~kg}$. $(0.41 \mathrm{MNW})$, 2 May, the penial opening is a craterlike prominence surrounded by long hairs, with a distinct opening $1 \mathrm{~mm}$. in diameter. On the newborn pup, the opening is usually marked by a fringe of white hairs. On the adult, the skin of the penial opening is distinct, naked, and flesh pink surrounded by black (plate 57).

The scrotum of the adult is dark gray, wrinkled, and virtually hairless. The testes descend in the third or fourth year, though the descent is less conspicuous than in land carnivores (plates 57 and 107-A).

\section{FEMALE EXTERNAL GENITALIA}

Of the female external genitalia, Bartholomew and Hoel (1953, p. 420) have written:

In the interval between parturition and the end of estrus [about 1 week] the vulva is swollen and protruding and the vestibular mucosa and vaginal orifice are a brilliant pink. By the time a female returns from her first trip to sea, the swelling is completely gone, and neither vestlbular mucosa nor vaginal orifice are conspicuous. The entire vulva appears dark brown or black.

On an adult female shot 18 minutes after copulation, the pink rosette of the vaginal opening was clearly visible from a distance of 100 meters. Ordinarily the vestibule appears black. (Plate 108.)

\section{NAVEL AND TAIL}

The navel can nearly always be seen in both sexes, regardless of age, as a disturbance in the lay of the hair, without distinction in color (plates 36, 44, and 102). 
On a fetus as small as $23.7 \mathrm{~g}$. (0.0049 MNW), female, 14 February, the tail is well formed and nearly adult in shape. The tail is difficult to measure; its free length is 15 to $20 \mathrm{~mm}$. on the newborn pup and 30 to $50 \mathrm{~mm}$. on the adult (plates 44, 58, and 107-B). On the field record of a 4-year-old male is noted "tail $32 \mathrm{~mm}$. plus $4 \mathrm{~mm}$. hairs, though standard length is about $62 \mathrm{~mm}$. when loose skin is pushed toward the body." As the seal reaches old age, the tail pelage becomes darker-at times almost black-and the underfur becomes sparser. (For further description of tail pelage, see preceding chapter.)

\section{Features of the Limbs}

\section{FLIPPERS AND CLAWS}

At birth, the flippers are brownish gray (Munsell 5 YR 4/1) and naked, except for sparse vellus on the dorsal surface of the fore flipper (plates 43 and 44). They soon turn almost black (plate 109). When wet, they are intensely black; when dry, dark grayish brown (5 YR 2/1); when very dry, as on an old bull sleeping in the sun, gray (plate 110). In a group color photograph, the flippers of certain individuals may catch and reflect the light of the sky, appearing white or bluish.

Forty flippers from 10 subadult male seals were cured in salt on St. Paul Island, 20 June 1949. (A set of 4 flippers weighs 2.5 to $3 \mathrm{lb}$. in fresh condition.) Half of the collection was sent to a large national manufacturer of glues and half to a large national producer of photographic gelatin. The former reported (personal correspondence) that "the resulting glue liquors were dark in color and had a characteristic 'fishy' odor. The glue was of low test and the percentage of glue obtained was much lower than for green salted stock obtained from cattle or other skin trimmings." The gelatin manufacturer reported "we have conducted some extensive tests with this material but our experiments disclose that it has no value in our operations."

The National Bureau of Standards also examined a barrel of flippers (U.S. Bureau of Fisheries, 1920) :

The experiments made by that bureau showed a yield of glue amounting to 67 percent of the weight of the salted flippers. The viscosity at $40^{\circ} \mathrm{C}$. of a 10 percent solution was . . 1.20, a little below Peter Cooper's glue, grade 17/8.

The only functional claws of the fur seal are those on the 3 inner toes of each hind flipper. The seal uses its claws exclusively for grooming the anterior parts of the body. The pup, especially, scratches itself frequently and vigorously during the summer molt. Development of the claws on five selected fetuses is described as follows: 


\section{Fetus of $23.7 \mathrm{~g}$. (0.0049 MNW), female, 14 February}

The sites of all 20 claws are visible. Each of the fore-claw sites on digits 1 to 4 is visible as a soft, whitish disc or pad of skin with a minute, teat-like projection. The outer hind claws are similar. The 3 inner hind claws, destined to become the only functional claws, are represented now by the largest of all the whitish pads. The claw rudiment on digit 5 of the fore flipper is a roundish disc below the surface of the skin and here it remains; it does not erupt with advancing age of the fetus.

\section{Fetus of $103 \mathrm{~g}$. (0.021 MNW), female, 20 January}

On each fore flipper, the first claw rudiment is distinctly conical and clawlike, though soft and white, $1 \mathrm{~mm}$. in length. The second to fourth rudiments decrease in size in this order. They are also clawlike. The fifth is no more than a faint pimple. The hind claws are well formed; the middle 3 robust and about $2 \mathrm{~mm}$. in length. (Compare plate 36.)

\section{Fetus of $1.09 \mathrm{~kg}$. (0.20 MNW), male, 25 March}

The 3 middle claws on each hind flipper are becoming firm and horny; brown with lighter tips and under parts.

Fetus of $3.31 \mathrm{~kg}$. (0.69 MNW), female, $6 \mathrm{July}$

A full-term fetus, delivered by caesarian section and killed 9 hours later. The vestigial claw sites on each fore flipper are scar-like pits with diameters as follows (first to fifth digits) : $1,0.5,0.5,0.5$, and less than 0.5. On each hind flipper, the claws are grayish in color, with distal one-third to one-half thin, flexible, and semicircular in cross section. They may be described as follows: (first) vestigial, length $10 \mathrm{~mm}$., basal $3 \mathrm{~mm}$. stiffer, distal $7 \mathrm{~mm}$. softer, paper-thin; (second) length $20 \mathrm{~mm}$.; (third) length $19 \mathrm{~mm}$; (fourth) length $18 \mathrm{~mm}$.; (fifth) vestigial, length $5 \mathrm{~mm}$. After birth, the first and fifth claws quickly become worn to nubbins.

\section{Fetus of $5.79 \mathrm{~kg}$. (1.07 MNW), male, $9 \mathrm{July}$}

The hind claws on this full-term fetus are nearly as long as the longest recorded for the newborn: $3,26,26,25,10 \mathrm{~cm}$. The claws dry out soon after birth, when they become brownish black along the basal part and horn-brown toward the thinner tip.

On adults, the third (middle) hind claw is usually the longest. On a 10-year-old male, the fore claws are rudiments hidden in skin pits 1 to $2 \mathrm{~mm}$. in diameter. The hind claws are $9,29,30,26$, and 4 $\mathrm{mm}$. in length on the first to fifth digits, respectively. On a 10-yearold female, the fore claws are also rudiments. The hind claws are 6 , $23,24,19$, and $7 \mathrm{~mm}$. in length. I do not know whether the claws continue to grow in later life, but I presume that they do not. Their position on top of the hind flipper protects them from the 
sort of attrition to which the claws of a cat or dog are exposed; yet the claws of the fur seal never exceed $30 \mathrm{~mm}$. in length. (Plates 110 and 111, A and B.)

\section{The Blubber Layer}

The blubber on the belly of a newborn fur seal was $3 \mathrm{~mm}$. thick; on the belly of an old cow, $50 \mathrm{~mm}$.; and on the belly of an old bull, $60 \mathrm{~mm}$.

On breeding bulls, some of them known to fast for at least 64 days in summer, the skin is loose and wrinkled by mid-August. Clearly there has been a loss of subcutaneous fat, though no actual measurements of the loss have been made. McLaren $(1958$, p. 63) found in the ringed seal Pusa that blubber made up about 45 percent of the body weight in winter, but only 20 percent in late June.

A reduction plant on St. Paul Island utilizes the byproducts of the Pribilof sealskin industry. The skinned carcasses are reduced to dry meal and "carcass oil", while the blubber scraped from the skins is reduced to "blubber oil". The yield of both kinds of oil over a 10-year period is shown in table 16. A subadult male seal weighing about $30 \mathrm{~kg}$. ( $66 \mathrm{lb}$.) yields roughly 0.6 gal. of blubber oil. Apparent variation from year to year in yield of oil per skin is believed to result, in a large part, from inconsistent handling of materials in the plant. Additional data, from records kept from 1950 to 1952 , are as follows: 1 subadult male sealskin yields about $0.13 \mathrm{cu}$. $\mathrm{ft}$. of crude blubber, and $1 \mathrm{cu}$. ft. of crude blubber yields 4.3 gal. blubber oil. Crude blubber is the plumped-up mass of fat, connective tissue, and muscle scraped from sealskins that have been allowed to soak overnight in cold sea water. On 25 July 1947, I weighed the crude blubber from 100 skins of "Group III" seals (mostly 3-year males) and from 100 skins of "Group IV" seals (mostly 4-year males). The average weights per skin were 11.7 lb. and $15.2 \mathrm{lb}$., respectively.

Thompson (1950, p. 726) gave an analysis of oil which had been heat rendered on St. Paul Island in 1949 from blubber scraped from sealskins:

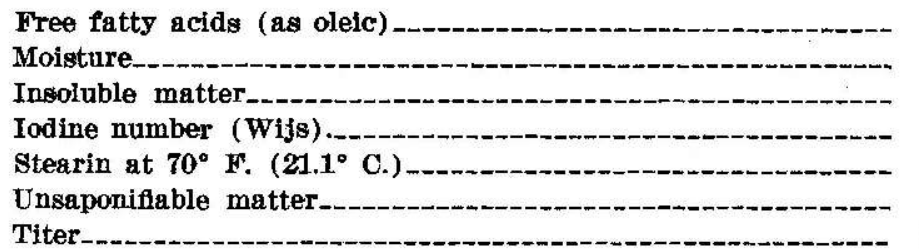

Lovibond color using a 1-inch column :

Yellow

Red.
$1.05 \%$

$0.34 \%$

$0.05 \%$

132. 5

$1.04 \%$

$0.49 \%$

70. $2^{\circ} \mathrm{F}$.

$\left(21.2^{\circ}\right.$ C.)

20

3. 5

$5530060-62-5$ 
Clegg (1951) reported on the characteristies of oil from coldrendered fur-seal blubber as follows:

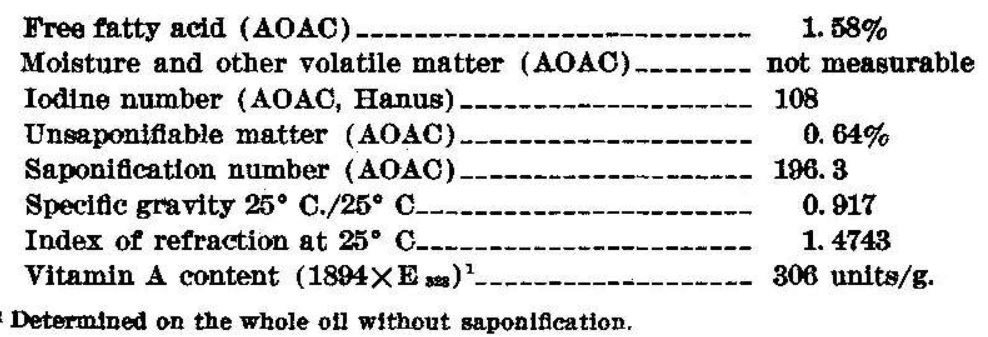

Minato (1949) gave additional data on "body oil" of a fur seal taken off Japan. Miyauchi and Sanford (1947) found little vitamin A in two samples of fur-seal blubber oil : 490 and 493 units per gram.

In a sample of fresh seal blubber, Wilber (1952) found total phospholipids 4.3 percent and total cholesterol 0.24 percent. The phospholipid content is high-as in perhaps all marine mammal fatsand is conceivably "associated with a high rate of fat turnover at the depots."

The sample analyzed by Wilber was reddish orange. The carcass of a seal with orange blubber, called by natives of the Pribilof Islands a "salmon-eater", may occasionally be seen on the killing field among carcasses with normal, creamy white blubber. Orange individuals include fewer than 1 percent of the total. Wilber concluded that the orange color is, in all probability, a carotenoid pigment. It may, in fact, be astaxanthin, a pigment found by Baalsrud (1956) in an abnormal, reddish-orange cod. Baalsrud stated that "There is as yet no obvious explanation for this sporadic appearance of astaxanthin in cod flesh, but somewhat similar observations have been made on whales. Occasionally red (astaxanthin-containing) whale-body oils and whale-liver oils are encountered; in this case pigmentation is taken to indicate an unspecified pathological condition."

Experts of the Fouke Fur Company say that an indistinct dark band can be seen along the dorsal region of the finished, dyed sealskin from old female animals. This is not present in male skins. It is referred to as an "oily band," though its real nature is unknown. Actually, it may be correlated with age rather than with sex; that is, only younger males commonly enter the commercial kill, as against females of all ages. 


\section{SUMMARY}

The midsummer population of northern fur seals Callorhinus ursinus is estimated at $1,978,000$. Of this number, $1,800,000$, or 91 percent, originate on the Pribiliof Islands. The Pribilof herd is capable of yielding 80,000 to 100,000 sealskins a year.

The epidermis of the sealskin has a cornified layer about 15 microns thick and a generative layer about 25 microns thick. The dermis or leather is 3 to $4 \mathrm{~mm}$. thick, thickest on old males. Regardless of age, the follicular (hair-rooot) stratum of the dermis does not vary appreciably from 2.3 to $2.4 \mathrm{~mm}$. in thickness. An apocrine sweat gland is associated with each hair bundle, rising from depths of 2 to $3 \mathrm{~mm}$. Sweat glands are not functional in the black pup.

The skin is pigmented (dark gray) on the following naked parts: nose, lips, rim of the eye, inside of the ear pinna, penial opening scrotum, vestibular opening, teats, anus, and flippers. It is also pigmented (light gray) beneath the pelage of the ear pinna and tail.

The pelage consists of bundles, rather evenly distributed, about 15 per sq. mm., each bundle with a guard hair that slopes, rooflike, above, and anterior to, a group of 35 to 40 underfur fibers. At the skin surface, the bundle is surrounded by a thick sheath. The guard hair is flanked by a pair of sebaceous glands seated 0.8 to $1.0 \mathrm{~mm}$. below the surface; functional even in the black pup. There is no hairerecting muscle. The guard hair is most deeply rooted. Behind it, the roots of the individual fur fibers are arranged in stairstep fashion, the most posterior fibers nearest the surface. The total number of hair and fur fibers per sq. mm. is about 570 ( 370,000 per sq. in.). The pelage is highly efficient as a thermal insulator; the underfur is water repellent. The haired surface of the body of the adult male has an area about 2.5 times that of the female.

Guard hairs may attain a length of $33 \mathrm{~mm}$. on the male (mane hairs to $70 \mathrm{~mm}$.) and $20 \mathrm{~mm}$. on the female. Underfur hairs may attain a length of $14 \mathrm{~mm}$. on the male and $13 \mathrm{~mm}$. on the female. The pelage of the belly is shorter than that of the back. The individual guard hairs and underfur hairs resemble those of mink; less closely, those of otter. The guard hair of the seal is stiff and flattened, lanceolate, medullated, heavily pigmented as a rule, with diamondpetal scale-pattern along most of the shaft. The underfur is much 
finer, distinctly wavy, without medulla, with very little pigment, and with pectinate scale-pattern along most of the shaft.

The fur-seal embryo implants in early November. Hair primordia are visible on a midwinter fetus of $1 / 200$ mean newborn weight, and erupted hairs on a midwinter fetus of $1 / 20$ mean newborn weight. Finer, paler hairs erupt in advance of coarser, blacker ones; the early fetus is gray. Heavy black guard hairs are aligned in a streak along the back of the fetus of $1 / 3$ mean newborn weight. Waves of hair-growth move backward and downward from the head and, slightly later, forward and downward from the rump. The top of the fetal flipper is covered with fine hairs which disappear at birth, though sweat glands remain. A fetus of $2.7 \mathrm{~kg}$. ( $1 / 2$ mean newborn weight) is well covered, except on the belly, with black hair.

The birthcoat is jet black, and its fibers are mature. It consists of 75 to 80 percent underhairs and 20 to 25 percent guard hairs. The arrangement of hair bundles is quite unlike that in the adult coat. In the birthcoat, there are 40 to 45 small bundles per sq. mm., each containing 1, 2, or 3 hairs. When the bundle includes 2 or 3 hairs, the posterior ones are underhairs.

The pup guard hairs are about 15 to $20 \mathrm{~mm}$. in length. To a certain extent, they intergrade in size and structure with the underhairs. The largest ones resemble adult guard hairs. The pup underhairs are 6 to $15 \mathrm{~mm}$. in length. They differ from adult underfur fibers in being shorter, coarser, less wavy, with more pigment, and often with medulla. In the birthcoat, adult-type underfur follicles are already taking form, deep in the dermis.

The height of the pupping season is 15 July. Two weeks later, the black birthcoat has started visibly to molt and has taken on a ragged appearance. By the end of September, it has largely been replaced by the adult-type pelage of the silver pup. The silver pelage persists for about 11 months, or until the end of August of the second summer.

The annual molt of the seal is believed to be a prolonged affair, 4 to 5 months from start to finish. The first adult-type molt (to silver pup) centers in September; the second in August (to yearling of autumn); the third in September (to 2-year-old of autumn); the fourth and subsequent molts in late September or October. The fibers are shed individually, with the result that the pelage is always intact and ready to meet the demands of an amphibious life. One rarely sees a "molt line." Molting is not accompanied by sloughing of the epidermis as in certain phocids. In autumn, the coat is duller and browner; in spring (at sea) it is brighter and more silvery. In late adolescence, ages 3 to 5 years, the whitish rump patches disappear, mane and wig hairs of the male start to lengthen, and pig- 
ment ceases to form at the roots of the whiskers (vibrissae) in both sexes.

At birth, there are 2 superciliary (above-the-eye) and 20 to 23 mystacial (snout) vibrissae on each side of the head. The number does not vary with age or sex. Nearly all of the vibrissae have erupted on a fetus of $1 / 200$ mean newborn weight, far in advance of the body hairs. Like sheep-wool fibers, the vibrissae are evergrowing, even in spring when the body-hair follicles are at rest. They continue to grow, so far as we know, throughout life. On a seal approaching the end of the first year of life, the longest vibrissa is growing at the rate of $0.2 \mathrm{~mm}$. per day. The vibrissae on the adult are 4 to 5 times longer than those on the newborn. The longest vibrissa of record has a maximum length on the male of $334 \mathrm{~mm}$. (13.1 in.), and on the female $220 \mathrm{~mm}$. (8.66 in.). The vibrissae are the only fur-seal hairs that taper all the way from base to tip.

The most commonly observed pelage anomalies are the following: (1) Genetic color-freaks such as albino, piebald, and chocolate. "Rubbed" pelage with guard hair absent from extensive areas; etiology unknown. (3) Naked, scabby patches on lousy pups. (4) Thick-skin, or pachyderma; etiology unknown. (5) Warty nodules, thus far seen only on the flippers; etiology unknown. (6) Femalelike pelage on males with infantile testes. (7) Algal and barnacle growths on the pelage, especially in winter.

The Pribilof sealskin industry is now about 175 years old. "Island operations" include killing, skinning, blubbering (flensing), and curing. "Factory operations" include unhairing, leathering, dyeing, and finishing. The skins receive a chamois, rather than chemical tannage. Field measurements of seals show that larger individuals tend to arrive on land in summer slightly ahead of smaller seals of the same age. However, as a result of selection by the killing crew, the composition of the take (by size of skin) remains constant throughout the sealing season. The weight of the blubbered, subadult, male pelt varies from $3.2 \mathrm{lb}$ (on a seal of 38-inch field length) to $8.5 \mathrm{lb}$. (on a 49 -inch seal). Commercial sealskins range in length and width as follows (inches) : Raw, salted: length 28-44.5, width 19-30. Finished, dyed: length 35.5-51.5, width 19-29. Thus, the finished skin gains considerably in length. Raw, salted sealskins are graded in five main categories, the smallest ("small medium") representing an area of about $718 \mathrm{sq}$. in. and the largest ("extra extra large") 1,261 sq. in. Breaking-strength tests applied by the Bureau of Standards reveal that sealskin leather compares favorably with the leather of light calfskin and sheepskin.

On the fetus, the ear pinna is flattened and somewhat flexible, like that of many land carnivores; on the adult, it is more cylindroid, 
stiffer, and more specialized for submarine life. It ceases to grow in about the 8th year of life, with a length (from notch) of $50 \mathrm{~mm}$. on males and $45 \mathrm{~mm}$. on females.

The 4 mammary teats (abnormally 5) are abdominal and equal in importance. On males and young females, they are hidden beneath the pelage. The mammary gland-complex is an extensive apron covering the lower thorax, abdomen, and sides of the body. It attains a thickness of $2 \mathrm{~cm}$. and an area of more than $2,000 \mathrm{sq}$. cm. ( $300 \mathrm{sq}$. in.). It has a milk capacity of 2 to 3 liters. A sample of milk contained 46 percent fat.

The testes descend in the third or fourth year. The tail is insignificant; throughout life it scarcely doubles in length. On each fetal flipper, five claw primordia are clearly visible. However, only the three middle claws of each hind flipper become functional; these are used exclusively for scratching the body. On an adult male, the middle claw (third digit) is about $30 \mathrm{~mm}$. in length.

The blubber may attain a thickness of $6 \mathrm{~cm}$., considerably less than that of phocid seals of comparable size. The crude blubber on a subadult male weighs 12 to $15 \mathrm{lb}$, and yields roughly $0.6 \mathrm{gal}$. of oil. The free fatty acid component of blubber oil is high (1.05 to 1.58 percent), as is the phospholipid content (4.3 percent). Reddishorange blubber, occasionally seen, may contain astaxanthin.

In appendix A, Munsell colors are given for 8 seals of selected age and sex. The middle value in an array of 39 colors recorded for fur-seal pelage is light brown. Seals from American and Asian waters are inseparable on the basis of color. Even to the trained observer, there are no sex distinctions in color pattern up to age 2 or 3 years. By age 4, the male is beginning to show a grayish mane and wig, and to lose his rump patches. 


\section{LITERATURE CITED}

ABEGalen, C. E., A. Y. RopPer, and F'. WIIKE.

1956-1958. Alaska fur seal investigations, Pribilof Islands, Alaska.

Report of field activities June-September . . . Published annually by U.S.

Fish and Wildlife Service, Seattle. Processed.

amgrican Medical Asgoctatron Jougral.

1943. Can hair turn white overnight? 121 : 161-162.

AOKI, T., and M. WADA.

1951. Functional activity of the sweat glands in the hairy skin of the dog.

Science, 114 : 123-124.

A DRKR, L.

1952. The anatomy of follicles producing wool-fibres, with special reference

to keratinization. Royal Society of Edinburgh, Transactions, 62: 191-254, 5 pls. ( 1 in color).

BLALGRUd, K.

1956. Astaxanthin in the muscle of cod. Nature, 178: 1182-1183.

Bachrach, M.

1946. Fur; a practical treatise. Rev. ed. Prentice-Hall, New York 672 p.

BAKER, R. C.

1957. Fur seals of the Pribilof Islands. U.S. Fish and Wildlife Service, Conservation in Action No. 12. 24 p.

Bartholomew, G. A., JR.

1951. Summary of observations made by ... Bartholomew ... on the social and reproductive behavior of the Alaska fur seal during June, July, and August, 1951. U.S. Fish and Wildlife Service, Seattle, MS report, 4 September, 3 p.

Baвtholomew, G. A., JB., and P. G. Hokt.

1953. Reproductive behavior of the Alaska fur seal, Callorhinus ursinus. Journal of Mammalogy, $34: 417-436$.

Basgert, C. F., and L. M. Luewellyn.

1948. The molting and fur growth pattern in the adult silver fox. American Midland Naturalist, $89: 597-601$.

1949. The molting and fur growth pattern in the adult mink. American Midland Naturalist, 42 : 751-756.

Bafsemt, C. F., O. P. Pearson, and F. Wilke.

1944. The effect of artificially increased length of day on molt, fur growth, and priming of silver fox pelts. Journal of Experimental Zoology, 96 : 7783.

Bergokrgen, B.

1931. Beitrăge zur Kenntnis der Haut einiger Pinnipedier . . . Skrifter Norske Videnskaps-Akademi i Oslo, Mat. -Naturvidensk. Klasse, 1931: 1-179, 22 pls.

Bisson NeTte, T. $\mathbf{H}$.

1935. Relations of hair cycles in ferrets to changes in the anterior bypophysis and to light cycles. Anatomical Record, 63 : 159-168.

1942. Anomalous seasonal coat-color-change in a small male Bonaparte's weasel . . A American Midland Naturalist, 28:327-333. 
Bisgonnette, T. H., and E. E. Bamley.

1944. Experimental modification and control of molts and changes in coatcolor in weasels by controlled lighting. New York Academy of Sclences, Annals, 45 : 221-260.

Bowers, D. E.

1956. A study of methods of color determination. Systematic Zoology, $5: 147-160,182$.

BOWKKR, R. C.

1931. Some physical properties of fur-seal skins. Technical Association of the Fur Industry, Journal, $2: 34-43$.

BgфNosTED, H. V.

1931. Bygninger af Snuden og Ansigtsmuskulaturen hos nogle Pinnlpedier . . . K. Danske Vidensk. Selsk. Skrifter, Naturvidensk. og Mathem. Afd. 9. Raekke, IV. 2, p. 41-85, 12 tbls.

Carlitgle, D. $B$.

1954. On the relationship between mammary, sweat, and sebaceous glands. Quarterly Journal of Microscopical Science, $95: 79-83$.

Carter, H. B.

1939. A histological technique for the estimation of follicle population per unit area of skin in the sheep. Council for Scientific and Industrial Research, Australia, Journal, 12 : 250-258.

Chase, H. B.

1954. Growth of the hair. Physiological Reviews, 34: 113-126 (Incl. bibl. of 78 titles).

Cuege, W.

1951. Characteristies of oil from cold-rendered fur seal blubber. U.S. Fish and Wildife Service, Commercial Fisheries Review, February, p. 30-31.

Danforth, C. H.

1925. Hair. Journal of the American Medieal Association, Chicago, $152 \mathrm{p}$. Fortune magazine.

1930. The seal and the U.S. Treasury. November, p. 70-72, 122, 124.

F'OUKE, P. B.

1949. St. Louis : fur sealskin market of the world. American National Fur and Market Journal, 27 : 13, 76-77.

Fotke Fur Company.

1958. The romance of the Alaska fur seal. Published by the company, St. Louis. 48 p.

Fub Trade Revrew.

1916. First batch of seals dyed in St. Louis. May, p. 80-81.

Green, D. D.

1947. Albino coyotes are rare. Journal of Mammalogy, 28: 63.

GunN, C. K.

1932. Phenomena of primeness. Canadian Journal of Research, 6: 387397,2 pls.

HALL, E. R.

1951. American weasels. University of Kansas Publications, Museum of Natural History, $4: 1-466,41$ pls.

HaMrLToN, J. B. (Editor)

1951. The growth, replacement, and types of hairs. Annals of the New York Academy of Sciences, 53: 461-752 (27 articles, 27 authors).

HARDY, J. I.

1935. A practical laboratory method of making thin cross sectlons of fibers. U.S. Department of Agriculture, Circular 378. $10 \mathrm{p}$. 
HARdY, J. I., and Thora M. PlitT

1940. An improved method for revealing the surface structure of fur fibers.

U.S. Fish and Wildlife Service, Wildlife Circular 7. $10 \mathrm{p}$.

HaUsman, L. A.

1939. Furs under the microscope. Nature Magazine, November, p. 501-503.

1944. Applied microscopy of hair. Scientific Monthly, 59: 195-202.

JORDAN, D. S., and others

1898. Observations on the fur seals of the Pribilof Islands, 1872-1897 . . . [part 2, p. 250-606]. In The fur seals and fur-seal islands of the North Pacific Ocean ... edited by David Starr Jordan. Govt. Print. Off., Washington, Treasury Department Document 2017, 4 parts, 1898-99.

KRUMBIEGEL, I.

1954. Körperbedeckung [vol. 1, p. 39-68]. In Biologie der Säugetiere. Agis Verlag GmbH, Krefeld. 2 vols.

Marrzz, A, and M. R. PAUL

1950. A dictionary of color. Ed. 2, MeGraw-Hill, New York, 208 p. Color plates.

Mathiak, H. A.

1938. A rapid method of cross-sectioning mammalian hairs. Journal of Wildlife Management, 2 : 162-164.

MATHUR, B. N.

1927. Theory of oil tannage with special reference to seal oil. Journal of the American Leather Chemists' Association, 22 : 2-44.

McLaren, I. A.

1958. The economics of seals in the eastern Canadian arctic. Fishery Research Board of Canada, Circular 1. $94 \mathrm{p}$.

Menaes, $\mathbf{R}$. W., and Lucille $\mathbf{K}$. Georo

1957. Survey of animal ringworm in the United States. U.S. Public Heslth Service, Public Health Reports, 72: 503-509.

Mru.JER, M. E.

1952. Guide to the dissection of the dog. Fd. 3., reprinted 1955. Published by the author, Ithaca, N.Y. $427 \mathrm{p}$.

MILIER, R. $\mathbf{S}$.

1958. The Munsell system of color notation. Journal of Mammalogy. 39 : 278-286.

Mrnato, A.

1949. Constituents of body oil from marine animals. Journal of the Pharmaceutical Society of Japan, 69:68-101.

MTYAUCHI, D. T., and F. B. SANFORD

1947. Vitamin A content of fur seal oils. U.S. Fish and Wildlife Service, Commercial Fisheries Review, $9: 5-8$.

Montagna, W.

1956. The structure and function of skin. Academic Press, New York, 356 p.

Montagina, W., and R. J. Harrison.

1957. Specializations in the skin of the seal (Phoca vitulina). American Journal of Anatomy, 100: 81-101, 6 plates.

Mungell Color Company

1954. Munsell soil color charts. Pub. by the company, Baltimore, 6 p., $\theta$ color plates, all loose-leaf.

MURRAY, M. D.

1958. Ecology of the louse Lepidophthirus macrorhini Bhderlein 1904, on the elephant seal Mirounga leonina (L). Nature, 182 : 404-405. 
NARAI, J., and T. ShIDA

1948. Sinus-hairs of the sei-whale (Balaenoptera borealis). Scientific Reports, Whales Research Institute, Tokyo, No. 1, p. 41-47.

NATIONAI BUREAU OF Standards

1955. The ISCC-NBC method of designating colors and a dictionary of color names. National Bureau of Standards Circular 553, $158 \mathrm{p}$.

NoBACK, C. $\mathbf{R}$.

1951. Morphology and phylogeny of hair. Annals of the New York Academy of Sciences, $53: 476-492$.

OdLand, G. F.

1954. Skin and epidermal derivatives [p. 428-457]. In Histology, edited by Roy 0 . Greep, with 13 contributors. Blakiston, New York, $12+953 \mathrm{p}$.

Parnet; J. P.

1951. Hair pattern and distribution in mammals. Annals of the New York Academy of Sciences, $53: 493-497$.

Partiddee, R. A.

1938. A study of the lipids of fresh seal skin. Journal of the American Leather Chemists' Association, 33 : 144-156.

Pearion, Anita K., and R. K. Ginders

1951. Further observations on the reproduction of the Alaskan fur seal. Anatomical Record, 111: 695-712.

Pocock, R. I.

1914. On the facial vibrissae of Mammalia. Proceedings of the Zoological Society of London, 1914, p. 889-912.

Poland, H.

1892. Fur-bearing animals in nature and commerce. Gurney and Jackson, London, 66 + $392 \mathrm{p}$.

RABSCH, B.

1953. Die Tranendrüsen der Säugetiere. Wiss. Z. Martin-Luther-Univ. Halle-Wittenberg, Jg. 2, Heft 8, Math.-natur. Reihe Nr. 4, p. 477-508.

RAND, R. W.

1958. The Oape fur seal Arctocephalus pusillus (Schreber) : its general characteristics and moult. Union of South Africa, Department of Commerce and Industries, Division of Fisheries, Investigational Report $21.52 \mathrm{p}$.

RopDy, W. T.

1956. Histology of animal skins [p. 4-40]. In The chemistry and technology of leather. Vol. 1. Preparation for tannage. Edited by Fred O'Flaherty, William T. Roddy, and Robert M. Lollar. Reinhold, New York, 2 vols.

Rothischild, MiriaM, and C. LANE

1957. Note on change of pelage in the stoat (Mustela erminea L.). Proceedings of the Zoological Society of London, $128: 602$.

SAMET, A.

1950. Pictorial encyclopedia of furs/from animal land to furtown. Published by the author, New York. $474 \mathrm{p}$.

ScheFEER, V. B.

1949. The clitoris bone in two pinnipeds. Journal of Mammalogy, 30:269270.

1950a. Growth layers on the teeth of Pinnipedia as an indication of age. Science, $112: 309-311$.

$1950 \mathrm{~b}$. Experiments in the marking of seals and sea-lions. U.S. Fish and Wildlife Service, Special Scientific Reports-Wildlife, No. 4. 33 p. 
1950c. The food of the Alaska fur seal. U.S. Flsh and Wildlife Service, Wildlife Leaflet $329.16 \mathrm{p}$. Processed.

1950d. Growth of the testes and baculum in the for seal, Callorhinus ursinus. Journal of Mammalogy, 31 : 384-394.

1951. Cryptorchid fur seals. American Midland Naturalist, 46:646-648.

1955. Body size with relation to population density in mammals. Journal of Mammalogy, $36: 493-515$.

1958. Seals, sea Hons, and walruses; a review of the Pinnipedia. Stanford University Press, 179 p., 32 plates.

Sorhertere, V. B., and K. W. KeNYoN

1952. The fur seal herd comes of age. National Geographic Magazine, $101: 491-512$ (10 color plates in text).

SOHHFTtK, V. B., and F. WHuke

1953. Relative growth in the northern fur seal. Growth, $17: 129-145$.

SoHöPs, P. (In collaboration with RUdolf FrTtzgchx).

1938. Pelze. J. J. Weber, Leipzig. 52 p. 16 color plates.

Shaiks, C. E.

1948. The pelt-primeness method of aging muskrats. American Midland Naturalist, $39: 179-187$.

SteVtengor, C. H.

1904. The skins of fur-seals [p. 298-308, pl. 31]. In Utilization of the skins of aquatic animals. U.S. Fish Commission, Report of Commissioner for 1902 , p. 281-352, 13 plates.

1905a. Leather from seal skins. Scientific American Supplement, 59: 24334-24335.

1905b. The skins of fur seals Scientiflc American Supplement, 59 : 2450224504.

SToves, J. L.

1958. Fibre mieroscropy/its technique and application. D. Van Nostrand, Princeton, 286 p.

TAYLOR, F. H. C., M. FUJINAGA, and F. WHKKE

1955. Distribution and food-habits of the fur seal of the North Pacific Ocean, U.S. Fish and Wildlife Service, Washington. 86 p.

Trrao, A.

1940. Microscopical examination of the leather of aquatic animals. Japanese Society of Scientific Fisheries (Tokyo), Bulletin, vol. 8, No. 6, p. 343-346.

Thompson, $\mathbf{\text { s. }}$ H.

1950. Seal fisheries [p. 716-732]. In Marine products of commerce, by Donald K. Tressler and James McW. Lemon. Reinhold, New York, 782 p.

U.S. BUREAU OF FIsHeries

1916. Dyeing and dressing Government fur-seal pelts. Fisheries Service Bulletin, No. 11 (April 1916), p. 4.

1917. Alaska fisherles and fur industrtes in 1918. Bur. Fish. Doc. 838 , $118 \mathrm{p}$.

1920. Fur-seal flippers as a source of glue. Fisheries Service Bulletin, No. 62 (July 1, 1920), p. 2.

1922. Alaska fishery and fur-seal industries in 1921. Document $983.85 \mathrm{p}$.

1923. Alaska fshery and fur-seal industries in 1922 . Document $951.118 \mathrm{p}$.

1938. Preparation of Pribilof Islands fur-seal skins for market. 3 p. Processed. 


\section{U.S. Dhpartment of Agriculture}

1954. Hyperkeratosis ( $X$-disease) of cattle. Department Leaflet 355.6 p. U.S. Fish AND WIIDLIFE SERvice

1952-57. Alaska fishery and fur-seal industries ... Fish and Wildife

Service, Statistical Digests, Nos. 23, 26 29, 31, 33, 35, 37, and 40 [annual reports for calendar years 1948-55].

WILBER, C. G.

1952. Fur seal blubber. Journal of Mammalogy, 33: 483-485.

WIIDMAN, A. B.

1954. The microscopy of animal textile fibres, including methods for the complete analysis of fibre blends. Wool Industries Research Association, Torridon, Headingley, Leeds, $209 \mathrm{p}$. Illustrations in text, 235 halftones, 11 color photographs, 88 line drawings.

WILKK, F.

1959. Fat content of fur-seal milk. Murrelet $39: 40$.

WOOLLARD, H. H.

1930. The cutaneous glands of man. Journal of Anatomy, 64: 415-421. Zoвkes, C. E.

1946. Marine microbiology. Chroniea Botanica, Waltham, 240 p. 


\section{TABLES}

TABLm 1.-Length and weight of male fetal seals collected off the North American coast, by 10-day periads, 1951-52

16-25 January 1951, off Bitka, Alaska (Ford Wilke, M\&); 15 Februsry to 29 June 1952, Callfornita to Gulf of Alaska (Taylor and others, 1955, table 27); summer, full-term fetal and newborn seals collected selectively on Pribilof Islands, Alasks, 19 June to 11 August 1940-50 (geheffer and Wilke, 1953, tables 1 and 2)]

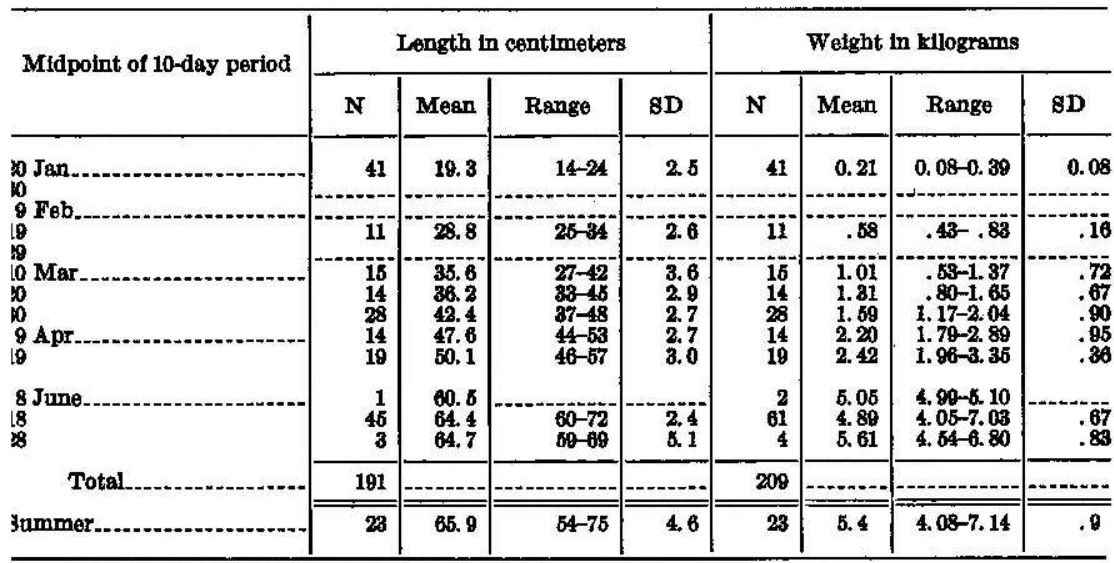

TABLE 2-Length and weight of female fetal seals collected off the North American coast, by 10-day periods, 1951-52

16-25 January 1951, off Bltka, Alesks (Ford Wilke, MS); 15 February to 29 June 1952, Callornis to Gulf of Alaska (Taylor and others, 1955, table 27); summer, full-term fetal and newborn seals collected selectively on Pribllof Islands, Alaska, 19 June to 11 August 1940-60 (Schefier and W1lke, 1958, tables 1 and 2)]

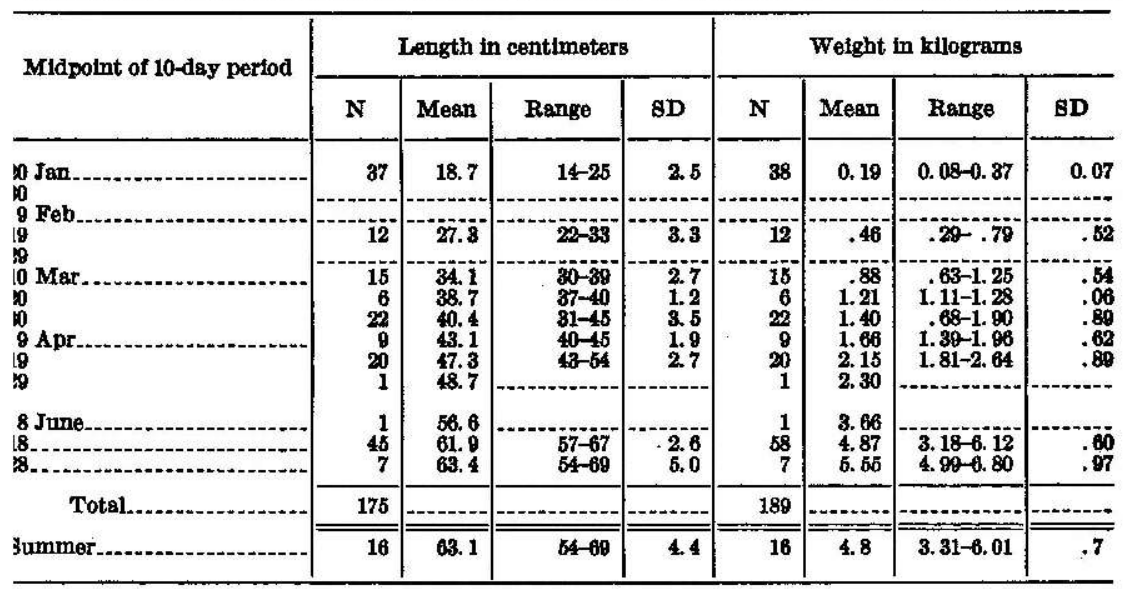


TABLE 3.-Mean lengths of underfur and guard-hair fibers, by age and sex of seal

[Measured on 114 tanned pelts at neck (10-25 cm. behind ears), back (mid-dorsum at level of fore flippers), and belly (akead of navel). Bexes are lumped through age 2. Figures in parentheses represent $N$, or num. ber in sample.]

\begin{tabular}{|c|c|c|c|c|c|c|c|c|}
\hline \multirow{3}{*}{ Age and sex } & \multirow{3}{*}{ Dates taken } & \multirow{3}{*}{ Mean date } & \multicolumn{6}{|c|}{ Length in millimeters 1} \\
\hline & & & \multicolumn{2}{|c|}{ Neck } & \multicolumn{2}{|c|}{ Back } & \multicolumn{2}{|c|}{ Belly } \\
\hline & & & $\begin{array}{c}\text { Under- } \\
\text { fur }\end{array}$ & $\begin{array}{l}\text { Guard } \\
\text { hairs }\end{array}$ & $\begin{array}{c}\text { Under- } \\
\text { fur }\end{array}$ & $\underset{\text { hairs }}{\text { Guard }}$ & $\begin{array}{l}\text { Under- } \\
\text { fur }\end{array}$ & $\underset{\text { hairs }}{\text { Guard }}$ \\
\hline Black pup, newborn ' & 11 June-22 July.- & 6 July (4) & 8.5 & 19.0 & 8.5 & 17.3 & 6.0 & 12,5 \\
\hline Black pup, molting.. & 11 Aug.-25 Sept. & 4 Sept. (4) -.- & (2) & 18. 7 & 8.7 & 18.7 & 5.5 & 11.0 \\
\hline Stlver pup........... & 29 Sept.-17 Nov & 25 Oct. (7) ... & $\begin{aligned}(3) \\
11.8\end{aligned}$ & $\begin{array}{r}(3) \\
18.2\end{array}$ & $\begin{array}{l}(3) \\
11.3\end{array}$ & 17,3 & $\begin{array}{l}\text { (2) } \\
7.0\end{array}$ & $\begin{array}{r}(2) \\
10.6\end{array}$ \\
\hline $\begin{array}{l}\text { Yearling, pelagic.... } \\
\text { Yearling, autumn... } \\
\text { Two-yesr-old } \\
\text { Three-year-old male. } \\
\text { Three-year-old } \\
\text { female. }\end{array}$ & $\begin{array}{l}\text { 16-25 Apr } \\
24 \text { Sept }-5 \text { Nov- } \\
20 \text { Aug.-21 Sept- } \\
22 \text { June-19 July.- } \\
23 \text { Mar.-15 Sept- }\end{array}$ & $\begin{array}{l}22 \text { Apr. (4)-- } \\
26 \text { Oct. (20)-- } \\
31 \text { Aug. (7)-- } \\
5 \text { July (10) } \\
8 \text { July (3) }\end{array}$ & $\begin{array}{l}12.7 \\
12.8 \\
12.8 \\
12.0 \\
13.2 \\
12.7\end{array}$ & $\begin{aligned} &(5) \\
& 18.3 \\
& 19.4 \\
& 16.3 \\
& 20.2 \\
& 18.3\end{aligned}$ & $\begin{array}{l}17 . \\
11.5 \\
11.3 \\
11.3 \\
11.4 \\
10.7\end{array}$ & $\begin{array}{l}\text { (7) } \\
17.7 \\
17.5 \\
15.3 \\
16.8 \\
16.0\end{array}$ & $\begin{array}{l}(5) \\
7.7 \\
8.0 \\
6.8 \\
7.2 \\
7.7\end{array}$ & $\begin{array}{r}12.3 \\
12.8 \\
9.4 \\
11.5 \\
12.0\end{array}$ \\
\hline $\begin{array}{l}\text { Four-year-old male.- } \\
\text { Four-yesr-old female- } \\
\text { Five-year-old male.- } \\
\text { Five-year-old female- } \\
\text { 8ix-year-old male-.-- } \\
\text { Six-year-old female.- } \\
\text { Seven-year-and- } \\
\text { older males. }\end{array}$ & $\begin{array}{l}\text { 16 June-22 July .- } \\
2 \text { Apr.-17 Aug--- } \\
28 \text { June-2 July } \\
14-24 \text { July } \\
18-24 \text { June.-. } \\
17 \text { June-16 July -- } \\
13 \text { June-5 July -- }\end{array}$ & $\begin{array}{l}4 \text { July (12) } \\
2 \text { July (9) } \\
1 \text { July (6) } \\
21 \text { July (2) } \\
21 \text { June (2).- } \\
2 \text { July (2) } \\
25 \text { June (9)-- }\end{array}$ & $\begin{array}{l}13.1 \\
12.6 \\
14.3 \\
12.3 \\
15.0 \\
12.0 \\
14.7\end{array}$ & $\begin{array}{l}20.1 \\
18.9 \\
21.0 \\
18.0 \\
26.5 \\
18.5 \\
46.8\end{array}$ & $\begin{array}{l}11.9 \\
10.9 \\
11.8 \\
11.0 \\
11.5 \\
11.0 \\
12.7\end{array}$ & $\begin{array}{l}17.9 \\
16.3 \\
17.8 \\
17.3 \\
18.5 \\
18.0 \\
23.0\end{array}$ & $\begin{array}{l}7.1 \\
7.2 \\
7.5 \\
7.3 \\
7.5 \\
7.0 \\
7.0\end{array}$ & $\begin{array}{l}11.3 \\
11.3 \\
11.8 \\
12.3 \\
12.0 \\
12.0 \\
13.1\end{array}$ \\
\hline $\begin{array}{l}\text { Beven-year-and- } \\
\text { older females. }\end{array}$ & 13 Mar.-3 Oct... & $10 \mathrm{July}(13)$ & 12.0 & 18. 5 & 11.0 & 17,0 & 7.0 & 10.8 \\
\hline $\begin{array}{l}\text { Maximum length of } \\
\text { fbers on male....- } \\
\text { Youngest age group } \\
\text { in which maxi- } \\
\text { mum length is } \\
\text { attained. }\end{array}$ & & & 16 & 70 & 14 & 33 & $1 \mathrm{yr}$. & 15 \\
\hline $\begin{array}{l}\text { attained } \\
\text { Maximum length of } \\
\text { flbers on female... }\end{array}$ & & & $\begin{array}{c}5 \text { yr. } \\
14\end{array}$ & $\begin{array}{c}8 \mathrm{yr} . \\
22\end{array}$ & $\begin{array}{l}7 y \text { yr. } \\
13\end{array}$ & $\begin{array}{l}8 y r . \\
20 .\end{array}$ & $\begin{array}{c}1 \mathrm{yr} . \\
10\end{array}$ & $\begin{array}{l}8 y r . \\
15\end{array}$ \\
\hline $\begin{array}{l}\text { Youmgest age group } \\
\text { in which maxi- } \\
\text { mum length is } \\
\text { 8ttained }\end{array}$ & & & $10+$ & \& yr. & \& yr. & $1 \mathrm{vr}$. & Adult & Adult \\
\hline
\end{tabular}

1 "Length" is equivalent to "depth" of underfur or guard hsir; with fibers in natural, slightly bent, or wavy attitude.

wavy attitude. mediate coat of short guard hairs, difficult to see without a lens, and ignored in the present table.

\section{TABED 4.-Length of longest vibrissa, by age and sest}

[The longest mystacial vibrissa is normally the posterior bristle in row 4 or 5 (counting 6 horizontal rows from top of snout to lip). Its length is measured from surface of skin to tip. Since the tip may be worn or broken, maximum length is more important than minimum]

\begin{tabular}{|c|c|c|c|c|c|c|}
\hline \multirow{2}{*}{ Age 1} & \multicolumn{2}{|c|}{ Number of specimens } & \multicolumn{2}{|c|}{ Range } & \multicolumn{2}{|c|}{ Mesn } \\
\hline & Male & Female & Male & Femsle & Male & Fomale \\
\hline $\begin{array}{l}0 \text { years } \\
1 \text { yearr- } \\
2 \text { years } \\
3 \text { years- } \\
4 \text { years } \\
5 \text { years } \\
6 \text { years } \\
7 \text { years } \\
8 \text { years } \\
9 \\
10 \text { years } \\
\text { "gdult" }\end{array}$ & $\begin{array}{r}17 \\
1 \\
5 \\
20 \\
24 \\
28 \\
22 \\
6 \\
4 \\
1 \\
1 \\
4\end{array}$ & $\begin{array}{r}14 \\
8 \\
9 \\
10 \\
10 \\
4 \\
3 \\
2 \\
1 \\
1 \\
5\end{array}$ & $\begin{array}{r}51-75 \\
95-134 \\
111-144 \\
96-155 \\
110-222 \\
115-212 \\
148-204 \\
132-255 \\
217-234\end{array}$ & $\begin{array}{r}52-63 \\
77-120 \\
80-115 \\
95-142 \\
79-141 \\
106-127 \\
124-164 \\
118-168 \\
104-220\end{array}$ & $\begin{array}{r}63 \\
104 \\
118 \\
124 \\
133 \\
149 \\
163 \\
185 \\
199 \\
306 \\
286 \\
259\end{array}$ & $\begin{array}{r}57 \\
98 \\
94 \\
111 \\
113 \\
117 \\
150 \\
145 \\
120 \\
120 \\
145\end{array}$ \\
\hline
\end{tabular}

1 Meles, totaling 133, were taken June-August (except 1 yearling on 13 September); females, totaling 67, were taken June-September. 
TABLE 5-Change in color of mystacial vibrissae with age, female seats

[Adapted from Abegglen and others (1957, p. 07; 1958, p. 186); based on 14,457 female seals]

\begin{tabular}{|c|c|c|c|c|c|c|}
\hline \multirow{2}{*}{ Age 2} & \multicolumn{2}{|c|}{ Black } & \multicolumn{2}{|c|}{ Black and white } & \multicolumn{2}{|c|}{ White } \\
\hline & Number & Percent & Number & Percent & Number & Percent \\
\hline $\begin{array}{l}3 \text { years } \\
4 \text { years } \\
6 \text { years } \\
6 \text { years... } \\
7 \text { years } \\
8 \text { years } \\
9 \text { years } \\
10 \text { years } \\
10+\end{array}$ & $\begin{array}{r}1,758 \\
1,067 \\
384 \\
57 \\
6 \\
2 \\
\\
\end{array}$ & $\begin{array}{r}86 \\
48 \\
14 \\
3 \\
1 \\
\\
\\
-0\end{array}$ & $\begin{array}{r}282 \\
1,329 \\
1,901 \\
886 \\
234 \\
92 \\
26 \\
7 \\
27\end{array}$ & $\begin{array}{r}14 \\
54 \\
67 \\
44 \\
20 \\
11 \\
4 \\
2 \\
2\end{array}$ & $\begin{array}{r}6 \\
74 \\
531 \\
1,072 \\
919 \\
747 \\
657 \\
428 \\
1,060\end{array}$ & $\begin{array}{r}3 \\
19 \\
58 \\
79 \\
89 \\
06 \\
98 \\
98\end{array}$ \\
\hline
\end{tabular}

1 Estimated from tooth-ridge counts.

TABLE 6.-Sizes of grading boards for raw, salted skins

[Mersured from outline tracings of boards provided by Fouke Fur Company in 1958; see figure 2]

\begin{tabular}{|c|c|c|c|}
\hline Size ciassifleation & Length & Width & Ares \\
\hline $\begin{array}{l}\text { Bmall medium. } \\
\text { Medium } \\
\text { Large } \\
\text { Extra large } \\
\text { Extra extra large. }\end{array}$ & $\begin{array}{l}\text { Inches: } \\
{ }_{80} \\
341 / 4 \\
8516 \\
894 \\
394\end{array}$ & $\begin{array}{l}\text { Inches } \\
2144 \\
241 / 4 \\
26 \\
27 \\
30\end{array}$ & $\begin{array}{r}\text { Square inches } \\
718 \\
877 \\
946 \\
1,039 \\
1,281\end{array}$ \\
\hline
\end{tabular}

TarLe 7.-Sizes of male sealskins taken in early season

[8ize classiflcation of raw, salted sting at Bt. Louis factory; skins orlginally stripped and blubbered on 8t. Paul Island from latter part of June through 15 July]

\begin{tabular}{|c|c|c|c|c|c|c|c|c|c|c|c|}
\hline \multirow{3}{*}{ Size classiflcation } & \multirow{2}{*}{\multicolumn{2}{|c|}{1038}} & \multirow{2}{*}{\multicolumn{2}{|c|}{1939}} & \multirow{2}{*}{\multicolumn{2}{|c|}{1940}} & \multirow{2}{*}{\multicolumn{2}{|c|}{1941}} & \multicolumn{3}{|c|}{4 years } \\
\hline & & & & & & & & & \multirow{2}{*}{$\begin{array}{c}\text { Total } \\
\text { number }\end{array}$} & \multicolumn{2}{|c|}{ Mean } \\
\hline & Num- & $\begin{array}{l}\text { Per- } \\
\text { cent }\end{array}$ & $\underset{\text { ber }}{\text { Num- }}$ & $\begin{array}{l}\text { Per- } \\
\text { cent }\end{array}$ & Num- & $\begin{array}{l}\text { Per- } \\
\text { cent }\end{array}$ & $\underset{\text { ber }}{\text { Num- }}$ & $\begin{array}{l}\text { Por- } \\
\text { cent }\end{array}$ & & $\underset{\text { ber }}{\text { Num- }}$ & $\begin{array}{l}\text { Per- } \\
\text { cent }\end{array}$ \\
\hline $\begin{array}{l}\text { Small modium } \\
\text { Medium } \\
\text { Large } \\
\text { Extra large } \\
\text { Extra extrs large. }\end{array}$ & $\begin{array}{r}6,507 \\
10,971 \\
2,308 \\
103 \\
7\end{array}$ & $\begin{array}{r}32.6 \\
54.9 \\
11.6 \\
.9 \\
\end{array}$ & $\begin{array}{r}13,818 \\
11,450 \\
1,636 \\
287 \\
21\end{array}$ & $\begin{array}{r}50.8 \\
42.1 \\
6.0 \\
1.0 \\
.1\end{array}$ & $\begin{array}{r}8,919 \\
14,058 \\
3,294 \\
155 \\
10\end{array}$ & $\begin{array}{r}33.7 \\
58.2 \\
12.5 \\
.6\end{array}$ & $\begin{array}{r}9,342 \\
15,368 \\
5,553 \\
1,258 \\
1124\end{array}$ & $\begin{array}{r}29.5 \\
48.7 \\
17.5 \\
3.9 \\
.4\end{array}$ & $\begin{array}{r}38,686 \\
51,847 \\
12,791 \\
1,863 \\
162\end{array}$ & $\begin{array}{r}9,646 \\
12,962 \\
3,198 \\
466 \\
40\end{array}$ & $\begin{array}{r}36.7 \\
49.8 \\
12.1 \\
1.8 \\
.1\end{array}$ \\
\hline Total & 19,956 & 100.0 & 27,212 & 100.0 & 26,436 & 100.0 & 31,645 & 100.0 & 105,249 & 26,312 & 100.0 \\
\hline
\end{tabular}

1 Including 4 wigg. 


\section{TABLE 8.-Sizes of male sealskins taken in late season}

[Size classifleation of raw, salted skins at St. Louis factory; skius originally stripned and blubbered on st. Paul Island from $16 \mathrm{July}$ to end of July or early August]

\begin{tabular}{|c|c|c|c|c|c|c|c|c|c|c|c|}
\hline \multirow{3}{*}{ Size classifleation } & \multirow{2}{*}{\multicolumn{2}{|c|}{1938}} & \multirow{2}{*}{\multicolumn{2}{|c|}{1989}} & \multirow{2}{*}{\multicolumn{2}{|c|}{1940}} & \multirow{2}{*}{\multicolumn{2}{|c|}{1941}} & \multicolumn{3}{|c|}{4 years } \\
\hline & & & & & & & & & \multirow{2}{*}{$\begin{array}{c}\text { Total } \\
\text { number }\end{array}$} & \multicolumn{2}{|c|}{ Mean } \\
\hline & $\underset{\text { ber }}{\text { Num- }}$ & $\begin{array}{l}\text { Per- } \\
\text { cent }\end{array}$ & $\underset{\text { ber }}{\text { Num- }}$ & $\begin{array}{l}\text { Per- } \\
\text { cent }\end{array}$ & $\underset{\text { ber }}{\text { Num- }}$ & $\begin{array}{l}\text { Per- } \\
\text { cent }\end{array}$ & Num- & $\begin{array}{l}\text { Per- } \\
\text { cent }\end{array}$ & & $\underset{\text { ber }}{\text { Num- }}$ & $\begin{array}{l}\text { Per- } \\
\text { cent }\end{array}$ \\
\hline $\begin{array}{l}\text { Small medium } \\
\text { Medium } \\
\text { Iarge } \\
\text { Extra large. } \\
\text { Extra extra large... }\end{array}$ & $\begin{array}{r}5,897 \\
9,139 \\
2,088 \\
120 \\
3\end{array}$ & $\begin{array}{r}34.1 \\
53.1 \\
12.1 \\
.7 \\
\end{array}$ & $\begin{array}{r}8,457 \\
8,529 \\
1,170 \\
106 \\
2\end{array}$ & $\begin{array}{r}46.3 \\
46.7 \\
6.4 \\
.6 \\
\end{array}$ & $\begin{array}{r}5,774 \\
8,558 \\
2,038 \\
167 \\
0\end{array}$ & $\begin{array}{r}34.8 \\
51.7 \\
12.3 \\
1.1\end{array}$ & $\begin{array}{r}13,893 \\
13,551 \\
3,750 \\
910 \\
1116\end{array}$ & $\begin{array}{r}43.1 \\
42.1 \\
11.6 \\
2.8 \\
.4\end{array}$ & $\begin{array}{r}34,021 \\
39,777 \\
9,046 \\
1,303 \\
130\end{array}$ & $\begin{array}{r}8,505 \\
9,944 \\
2,261 \\
326 \\
32\end{array}$ & $\begin{array}{r}40.4 \\
47.2 \\
10.7 \\
1.6 \\
.1\end{array}$ \\
\hline Total & 17,247 & 100.0 & 18,264 & 100.0 & 16,546 & 100.0 & 32.220 & 100.0 & 84,277 & 21,039 & 100.0 \\
\hline
\end{tabular}

1 Including 7 wigs.

TABLE 9.-Comparison of body weights of female seals arriving on land in early summer and in late summer

[From a ktll of approximately 500 seals, none with full-term fotus, on hauling grounds and rookeries of St. Paul Island, 15 June-4 September 1953 . (Ford Wilke, Ms, 1953)]

\begin{tabular}{|c|c|c|c|}
\hline Age 1 & $\begin{array}{l}\text { Earliest } 25 \\
\text { seals, mean } \\
\text { welght in } \\
\text { pounds }\end{array}$ & $\begin{array}{l}\text { Latest } 25 \\
\text { seals, mesn } \\
\text { welght in } \\
\text { pounds }\end{array}$ & $\begin{array}{l}\text { Percent } \\
\text { difference }\end{array}$ \\
\hline $\begin{array}{l}4 \text { years }^{2} \text { - } 5 \text { years } \\
6 \text { years } \\
7 \text { years }\end{array}$ & $\begin{array}{l}62.9 \\
71.9 \\
77.7 \\
78.6\end{array}$ & $\begin{array}{l}55.2 \\
62.1 \\
70.8 \\
71.2\end{array}$ & $\begin{array}{r}13.9 \\
15.8 \\
9.7 \\
10.4\end{array}$ \\
\hline
\end{tabular}

1 Estimated from tooth-ridge counts.

3 Total sample 34, rather than 50, in this age class; thus, total number seals measured 184.

TABLE 10.-Weight of fresh male sealsliin with relation to feld length of seal

[Sample of 558 skins from subadult males, mostly ages 3 and 4 years, taken in regular commercial kdll, St. Paul Island, 17 June to 27 July 1949. Length is "fleld length" or approximate length from snout to tip of tail on unskinned animal. Weight is of pelt, freshly blubbered and wrung, without mask and filppers.

\begin{tabular}{|c|c|c|c|c|c|}
\hline \multirow{2}{*}{ Length of seal } & \multirow{2}{*}{$\mathbf{N}$} & \multicolumn{3}{|c|}{ Weight of pelt in pounds } & \multirow{2}{*}{$\mathbf{V}$} \\
\hline & & Range & Mean & SD & \\
\hline $\begin{array}{l}38 \text { inches } \\
39 \text { inchess } \\
40 \text { 1nches } \\
41 \text { inches. } \\
42 \text { inches } \\
43 \text { inches } \\
44 \text { inches } \\
45 \text { inches } \\
46 \text { inches } \\
47 \text { inches } \\
48 \text { inches } \\
40 \text { inches } \\
50 \text { inches } \\
51 \text { inches. }\end{array}$ & $\begin{array}{r}8 \\
48 \\
49 \\
54 \\
46 \\
54 \\
44 \\
46 \\
49 \\
48 \\
46 \\
41 \\
15 \\
11\end{array}$ & $\begin{array}{l}3.2-4.2 \\
3.1-4.6 \\
3.3-5.8 \\
3.7-5.0 \\
3.9-6.1 \\
4.0-6.7 \\
4.0-7.5 \\
4.6-7.2 \\
5.1-7.3 \\
5.4-7.1 \\
5.5-7.7 \\
5.2-8.5 \\
6.0-8.0 \\
6.2-8.5\end{array}$ & $\begin{array}{l}3.7 \\
3.9 \\
4.3 \\
4.4 \\
4.7 \\
5.0 \\
5.5 \\
5.7 \\
6.0 \\
6.2 \\
6.4 \\
6.7 \\
7.0 \\
7.3\end{array}$ & $\begin{array}{l}0.33 \\
.33 \\
.48 \\
.31 \\
.50 \\
.62 \\
.75 \\
.59 \\
.50 \\
.40 \\
.51 \\
.62 \\
.63 \\
.69\end{array}$ & $\begin{array}{r}\text { Percent } \\
9.1 \\
8.6 \\
11.8 \\
7.0 \\
10.7 \\
12.4 \\
13.6 \\
10.3 \\
8.3 \\
6.5 \\
8.0 \\
9.8 \\
9.0 \\
9.5\end{array}$ \\
\hline
\end{tabular}


TABLE 11.-Trade classifcation of raw, salted, male sealskin with relation to fleld length of seal

[Based on pelts of 523 subadult male seals sampled at random between 18 June and 20 July 1946, on Bt. Paul Island; classifled by Harry Gladson in 1947]

\begin{tabular}{|c|c|c|c|c|c|c|c|c|c|c|c|c|}
\hline \multirow{2}{*}{$\begin{array}{l}\text { Field length } \\
\text { and quarter }\end{array}$} & \multicolumn{2}{|c|}{$\begin{array}{c}\text { Small } \\
\text { medium }\end{array}$} & \multicolumn{2}{|c|}{ Medium } & \multicolumn{2}{|c|}{$\operatorname{targ} \theta$} & \multicolumn{2}{|c|}{ Extra large } & \multicolumn{2}{|c|}{$\begin{array}{c}\text { Extra extra } \\
\text { large }\end{array}$} & \multicolumn{2}{|c|}{ All clsgses } \\
\hline & $\underset{\text { ber }}{\text { Num- }}$ & $\begin{array}{l}\text { Per- } \\
\text { cent }\end{array}$ & $\underset{\text { ber }}{\text { Nura- }}$ & $\begin{array}{l}\text { Per- } \\
\text { cent }\end{array}$ & $\underset{\text { ber }}{\text { Num- }}$ & $\begin{array}{l}\text { Per- } \\
\text { cent }\end{array}$ & $\underset{\substack{\text { Num- } \\
\text { ber }}}{\text {. }}$ & $\begin{array}{l}\text { Per- } \\
\text { cent }\end{array}$ & $\underset{\text { ber }}{\text { Num- }}$ & $\begin{array}{l}\text { Per- } \\
\text { cent }\end{array}$ & $\begin{array}{c}\text { Num- } \\
\text { ber }\end{array}$ & $\begin{array}{l}\text { Per- } \\
\text { cent }\end{array}$ \\
\hline $\begin{array}{l}41 \text { Indhes: } \\
\text { First. } \\
\text { Becond..... } \\
\text { Third } \\
\text { Fourth...... }\end{array}$ & $\begin{array}{r}2 \\
9 \\
10 \\
11\end{array}$ & - & $\begin{array}{r}2 \\
2 \\
10 \\
6\end{array}$ & 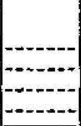 & 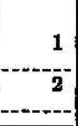 & - & \begin{tabular}{c}
1 \\
-1 \\
\hdashline \\
\hdashline
\end{tabular} & & & & $\begin{array}{r}6 \\
11 \\
22 \\
17\end{array}$ & |-n \\
\hline Deason...- & 32 & 57.1 & 20 & 35.7 & 8 & 5.4 & 1 & 1.8 & -- & & 56 & 100 \\
\hline $\begin{array}{l}42 \text { Inches: } \\
\text { First. } \\
\text { Second. } \\
\text { Third..... } \\
\text { Fourth.... }\end{array}$ & $\begin{array}{r}1 \\
5 \\
6 \\
10\end{array}$ & - & $\begin{array}{r}4 \\
6 \\
11 \\
9\end{array}$ & 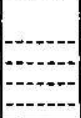 & $\begin{array}{r}1 \\
-2 \\
-2\end{array}$ & & & & & & $\begin{array}{r}6 \\
11 \\
19 \\
19\end{array}$ & |-10 \\
\hline Segson. & 22. & 40.0 & 30 & 54.5 & 3 & 5.5 & $\ldots$ & $2 \ldots . . .-$ & $\ldots$ & $-\cdots$ & 55 & 100 \\
\hline $\begin{array}{l}43 \text { inches: } \\
\text { First. } \\
\text { Becond. } \\
\text { Third } \\
\text { Fourth..... }\end{array}$ & $\begin{array}{r}1 \\
1 \\
8\end{array}$ & 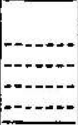 & $\begin{array}{r}3 \\
8 \\
19 \\
6\end{array}$ & - & $\begin{array}{l}-\overline{3} \\
2 \\
1\end{array}$ & 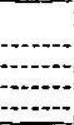 & $\begin{array}{r}1 \\
1 \\
\hdashline\end{array}$ & & 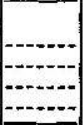 & & $\begin{array}{r}5 \\
12 \\
22 \\
14\end{array}$ & -10. \\
\hline Beason.... & 10 & 18.9 & 36 & 68.0 & 6 & 11.8 & 2 & 8.8 & $\ldots$ & $\ldots$ & 53 & 100 \\
\hline $\begin{array}{l}4 \text { inches: } \\
\text { First. } \\
\text { Second. } \\
\text { Third..... } \\
\text { Fourth.... }\end{array}$ & $\begin{array}{r}3 \\
1 \\
2 \\
\end{array}$ & 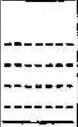 & $\begin{array}{r}2 \\
7 \\
18 \\
17\end{array}$ & 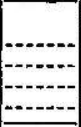 & $\begin{array}{c}1 \\
-\overline{2} \\
2\end{array}$ & 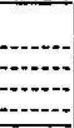 & $\begin{array}{c}2 \\
-2 \\
-2 \\
-2\end{array}$ & & & & $\begin{array}{r}5 \\
10 \\
16 \\
21\end{array}$ & - \\
\hline Beeson. & 6 & 11. 6 & 39 & 75.0 & 5 & 9.6 & 2 & 3.8 & $=--$ & $\ldots$ & 52 & 100 \\
\hline $\begin{array}{l}45 \text { Inches: } \\
\text { First.--- } \\
\text { Second.- } \\
\text { Third..- } \\
\text { Fourth. }\end{array}$ & $\begin{array}{l}1 \\
1 \\
6\end{array}$ & 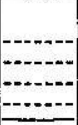 & $\begin{array}{r}3 \\
8 \\
10 \\
7\end{array}$ & מn & $\begin{array}{l}2 \\
6 \\
5 \\
3\end{array}$ & - & $\begin{array}{r}1 \\
4 \\
4\end{array}$ & בי & - & - & $\begin{array}{r}5 \\
11 \\
20 \\
16\end{array}$ & 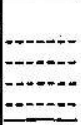 \\
\hline Sesson & 8 & 15.4 & 23 & 44.2 & 18 & 80.8 & 5 & 9.6 & $-\ldots$ & 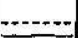 & 82 & 100 \\
\hline $\begin{array}{l}46 \text { inches: } \\
\text { Flrst... } \\
\text { Becond.. } \\
\text { Thtrd.... } \\
\text { Pourth.. }\end{array}$ & 1 & 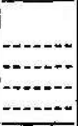 & $\begin{array}{l}3 \\
5 \\
2 \\
2\end{array}$ & 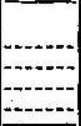 & $\begin{array}{r}11 \\
8 \\
11 \\
4\end{array}$ & 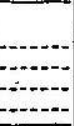 & $\begin{array}{l}5 \\
8 \\
2 \\
1\end{array}$ & 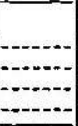 & $\cdots$ & - & $\begin{array}{r}19 \\
21 \\
16 \\
7\end{array}$ & 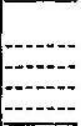 \\
\hline Besson & 1 & 1.6 & 12 & 19.0 & 34 & 5. 0 & 16 & 25.4 & $\ldots \ldots$ &..-- & 63 & 100 \\
\hline $\begin{array}{l}47 \text { inches: } \\
\text { First.-... } \\
\text { Seoond.-. } \\
\text { Third... } \\
\text { Fourth.. }\end{array}$ & & & $\begin{array}{l}\mathbf{3} \\
\mathbf{8} \\
\mathbf{2} \\
\mathbf{2}\end{array}$ & בn & $\begin{array}{l}6 \\
7 \\
9 \\
4 \\
\end{array}$ & 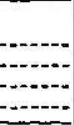 & $\begin{array}{r}6 \\
6 \\
2 \\
\\
\end{array}$ & 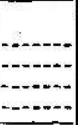 & 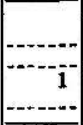 & 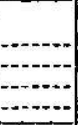 & $\begin{array}{r}15 \\
21 \\
10 \\
6\end{array}$ & - \\
\hline Messon. & 1 & 1. 7 & 15 & 28.8 & 26 & 45.6 & 14 & 24. 6 & 1 & 1.8 & 57 & 100 \\
\hline $\begin{array}{l}48 \text { Inches: } \\
\text { First } \\
\text { Second } \\
\text { Third } \\
\text { Fourth...... }\end{array}$ & & & $\begin{array}{l}2 \\
1 \\
4 \\
3\end{array}$ & - & $\begin{array}{l}6 \\
7 \\
5 \\
8\end{array}$ & 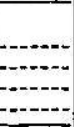 & $\begin{array}{r}7 \\
15 \\
8 \\
\end{array}$ & 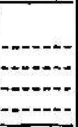 & $\begin{array}{r}2 \\
1 \\
\hdashline \\
\hdashline\end{array}$ & 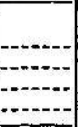 & $\begin{array}{r}17 \\
24 \\
12 \\
6\end{array}$ & 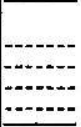 \\
\hline - Beason --- & -....... & $\ldots$ & 10 & 16.9 & 21 & 35.6 & 26 & 42.4 & 3 & 5.1 & 59 & 100 \\
\hline $\begin{array}{l}49 \text { inches: } \\
\text { First. } \\
\text { Becond. } \\
\text { Third. } \\
\text { Fourth..... }\end{array}$ & & & $\begin{array}{r}1 \\
1 \\
1 \\
\end{array}$ & 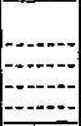 & $\begin{array}{r}5 \\
7 \\
-8 \\
\end{array}$ & 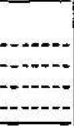 & $\begin{array}{r}8 \\
8 \\
2 \\
\end{array}$ & 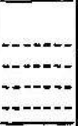 & \begin{tabular}{|c|}
$\mathbf{8}$ \\
\\
\end{tabular} & 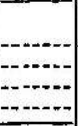 & $\begin{array}{r}17 \\
16 \\
1 \\
5\end{array}$ & 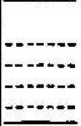 \\
\hline Season...- & - & $\ldots$ & 8 & 7.7 & 15 & 885 & 18 & 46. 1 & 3 & 7.7 & 89 & 100 \\
\hline
\end{tabular}


TABLE 11.-Trade classification of raw, salted, male gealskin with relation to feld length of seat-Continued

\begin{tabular}{|c|c|c|c|c|c|c|c|c|c|c|c|c|}
\hline \multirow{2}{*}{$\begin{array}{l}\text { Field length } \\
\text { and quarter }\end{array}$} & \multicolumn{2}{|c|}{$\begin{array}{c}\text { Smsll } \\
\text { medium }\end{array}$} & \multicolumn{2}{|c|}{ Medium } & \multicolumn{2}{|c|}{ Large } & \multicolumn{2}{|c|}{ Extra large } & \multicolumn{2}{|c|}{$\begin{array}{c}\text { Extra extra } \\
\text { large }\end{array}$} & \multicolumn{2}{|c|}{ All classes } \\
\hline & Num- & $\begin{array}{l}\text { Per- } \\
\text { cent }\end{array}$ & $\underset{\text { ber }}{\text { Num- }}$ & $\begin{array}{l}\text { Per- } \\
\text { cent }\end{array}$ & Num- & $\begin{array}{l}\text { Per- } \\
\text { cent }\end{array}$ & $\underset{\text { ber }}{\text { Num- }}$ & $\begin{array}{l}\text { Per- } \\
\text { cent }\end{array}$ & $\underset{\text { ber }}{\text { Num- }}$ & $\begin{array}{l}\text { Per- } \\
\text { cent }\end{array}$ & $\underset{\text { ber }}{\text { Num. }}$ & $\begin{array}{l}\text { Per- } \\
\text { cent }\end{array}$ \\
\hline $\begin{array}{l}80 \text { Inches: } \\
\text { First } \\
\text { Becond } \\
\text { Third } \\
\text { Fourth..... } \\
\end{array}$ & & & 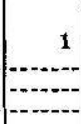 & - & $\begin{array}{c}6 \\
\cdots \\
\cdots\end{array}$ & & $\begin{array}{l}7 \\
5 \\
2\end{array}$ & 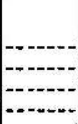 & \begin{tabular}{l}
3 \\
1 \\
\hdashline- \\
$\cdots$
\end{tabular} & & $\begin{array}{r}17 \\
6 \\
2 \\
2\end{array}$ & 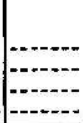 \\
\hline Beason.- & $\ldots$ & - & 1 & 4.0 & 6 & 24.0 & 14 & 86.0 & 4 & 16. 0 & 25 & 100 \\
\hline $\begin{array}{l}51 \text { inches: } \\
\text { First } \\
\text { Gecond } \\
\text { Third } \\
\text { Fourth. }\end{array}$ & & $-\infty$ & & 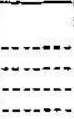 & $\begin{array}{r}2 \\
-1 \\
\hdashline\end{array}$ & & $\begin{array}{l}3 \\
8 \\
1 \\
1\end{array}$ & 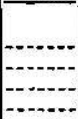 & 1 & - & $\begin{array}{l}\mathbf{6} \\
\mathbf{3} \\
\mathbf{2} \\
\mathbf{1}\end{array}$ & - \\
\hline Serson & -....... & $-\ldots$. & $-\ldots$ & $-\ldots$ & 3 & 25.0 & 8 & 66.7 & 1 & 8.3 & 12 & 100 \\
\hline $\begin{array}{l}\text { All lengths: } \\
\text { First } \\
\text { Becond. } \\
\text { Third } \\
\text { Fourth. }\end{array}$ & $\begin{array}{r}1 \\
19 \\
20 \\
37\end{array}$ & $\mid-\ldots$ & $\begin{array}{l}24 \\
41 \\
72 \\
51\end{array}$ & - & $\begin{array}{l}41 \\
38 \\
89 \\
20\end{array}$ & 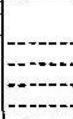 & $\begin{array}{r}40 \\
46 \\
15 \\
4\end{array}$ & $\mid$ & $\begin{array}{r}9 \\
\mathbf{2} \\
\mathbf{1} \\
\end{array}$ & 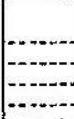 & $\begin{array}{l}118 \\
146 \\
147 \\
112\end{array}$ & 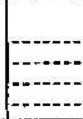 \\
\hline Beason & 80 & 15.3 & 188 & 35.9 & 138 & 26.4 & 105 & 20.1 & 12 & 2.3 & 523 & 100 \\
\hline
\end{tabular}

TABLs 12.-Trade olassiflation of Anished, dyed, male sealskin with relation to fleld length of seal

[Based on pelts of 523 subadult male seals sampled at random betweon 18 June and 20 July 1946, on 8t. Paul Island; classifled by Harry Gladson in 1947]

\begin{tabular}{|c|c|c|c|c|c|c|c|c|c|c|c|c|}
\hline \multirow{2}{*}{$\begin{array}{l}\text { Field length } \\
\text { and quarter }\end{array}$} & \multicolumn{2}{|c|}{$\begin{array}{l}\text { Bmall } \\
\text { medium }\end{array}$} & \multicolumn{2}{|c|}{ Medium } & \multicolumn{2}{|c|}{ Large } & \multicolumn{2}{|c|}{ Extera large } & \multicolumn{2}{|c|}{$\begin{array}{c}\text { Extra extra } \\
\text { Iarge }\end{array}$} & \multicolumn{2}{|c|}{ All classes } \\
\hline & $\underset{\text { ber }}{\text { Num. }}$ & $\begin{array}{l}\text { Per- } \\
\text { cent }\end{array}$ & Num- & $\begin{array}{l}\text { Per- } \\
\text { cent }\end{array}$ & $\begin{array}{l}\text { Num- } \\
\text { ber }\end{array}$ & $\begin{array}{l}\text { Per- } \\
\text { cent }\end{array}$ & $\underset{\text { ber }}{\text { Num- }}$ & $\begin{array}{l}\text { Per- } \\
\text { cent }\end{array}$ & $\underset{\text { ber }}{\text { Num- }}$ & $\begin{array}{l}\text { Per- } \\
\text { cent }\end{array}$ & $\underset{\text { ber }}{\text { Nom- }}$ & $\begin{array}{l}\text { Per- } \\
\text { cent }\end{array}$ \\
\hline $\begin{array}{l}11 \text { Inches: } \\
\text { First... } \\
\text { Second... } \\
\text { Third } \\
\text { Fourth...... }\end{array}$ & $\begin{array}{l}1 \\
4 \\
4\end{array}$ & 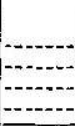 & $\begin{array}{r}3 \\
7 \\
16 \\
13\end{array}$ & - & $\begin{array}{r}2 \\
3 \\
\mathbf{2} \\
-- \\
\end{array}$ & - & \begin{tabular}{r}
1 \\
\hdashline \\
-2 \\
\end{tabular} & & & & $\begin{array}{r}6 \\
11 \\
22 \\
17 \\
\end{array}$ & - \\
\hline Segson.... & $g$ & 16. 1 & 39 & 69.6 & 7 & 12.5 & 1 & 1.8 & & $\ldots$ & 56 & 100 \\
\hline $\begin{array}{l}42 \text { inches: } \\
\text { First.... } \\
\text { Becond. } \\
\text { Third.... } \\
\text { Fourth.... }\end{array}$ & $\begin{array}{r}2 \\
2 \\
\hdashline\end{array}$ & 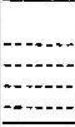 & $\begin{array}{r}3 \\
9 \\
11 \\
18\end{array}$ & - & $\begin{array}{l}3 \\
2 \\
6 \\
1\end{array}$ & 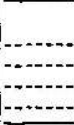 & & & & & $\begin{array}{r}6 \\
11 \\
19 \\
19\end{array}$ & $\mid \begin{array}{ll}-1 \\
-\cdots\end{array}$ \\
\hline Beason...- & 2 & 3.6 & 41 & 74. 6 & 12 & 21.8 & & $\ldots$ & -nen- & $-2-2$ & 56 & 100 \\
\hline $\begin{array}{l}48 \text { Inches: } \\
\text { First } \\
\text { Second. } \\
\text { Third } \\
\text { Fourth.... }\end{array}$ & 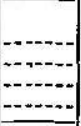 & & $\begin{array}{r}2 \\
6 \\
17 \\
11\end{array}$ & - & $\begin{array}{l}8 \\
5 \\
5 \\
3 \\
\end{array}$ & - & & & & & $\begin{array}{r}5 \\
12 \\
22 \\
14\end{array}$ & 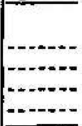 \\
\hline Season.... & 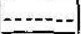 & $\ldots$ & 36 & 67.9 & 16 & 30.2 & 1 & 1.9 & $-\ldots$ & $--\ldots$ & 53 & 100 \\
\hline $\begin{array}{l}44 \text { Inches: } \\
\text { First. } \\
\text { Becond. } \\
\text { Third. } \\
\text { Fourth. }\end{array}$ & & 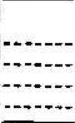 & $\begin{array}{r}3 \\
7 \\
12\end{array}$ & - & $\begin{array}{l}2 \\
7 \\
9 \\
9\end{array}$ & 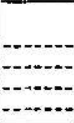 & $\begin{array}{r}\boldsymbol{b} \\
\hdashline \\
\hdashline\end{array}$ & & & & $\begin{array}{l}5 \\
10 \\
16 \\
21\end{array}$ & - \\
\hline Beason & 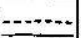 & בno & 22 & 42.3 & 27 & 51. 9 & 3 & 5.8 & …… & 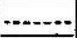 & 52 & 100 \\
\hline
\end{tabular}


TABLE 12.-Trade classification of Anished, dyed, male sealskin with relation to field length of seal-Continued

\begin{tabular}{|c|c|c|c|c|c|c|c|c|c|c|c|c|}
\hline \multirow{2}{*}{$\begin{array}{l}\text { Field length } \\
\text { and quarter }\end{array}$} & \multicolumn{2}{|c|}{$\begin{array}{c}\text { 8mall } \\
\text { medium }\end{array}$} & \multicolumn{2}{|c|}{ Mediam } & \multicolumn{2}{|c|}{ Large } & \multicolumn{2}{|c|}{ Fixtca large } & \multicolumn{2}{|c|}{$\begin{array}{c}\text { Extra extra } \\
\text { large }\end{array}$} & \multicolumn{2}{|c|}{ All classes } \\
\hline & $\underset{\text { Ner }}{\text { Num- }}$ & $\begin{array}{l}\text { Per- } \\
\text { cent }\end{array}$ & Num- & $\begin{array}{l}\text { Per- } \\
\text { cent }\end{array}$ & $\underset{\text { ber }}{\text { Num- }}$ & $\begin{array}{l}\text { Per- } \\
\text { cent }\end{array}$ & Num- & $\begin{array}{l}\text { Per: } \\
\text { cent }\end{array}$ & $\underset{\text { ber }}{\text { Num- }}$ & $\begin{array}{l}\text { Per- } \\
\text { cent }\end{array}$ & Num- & $\begin{array}{l}\text { Per- } \\
\text { cent }\end{array}$ \\
\hline 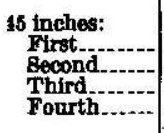 & & \begin{tabular}{|c|}
$-\cdots$ \\
\hdashline-1. \\
$-\cdots$ \\
\end{tabular} & $\begin{array}{r}2 \\
6 \\
11 \\
\end{array}$ & 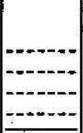 & $\begin{array}{r}3 \\
6 \\
10 \\
5 \\
\end{array}$ & 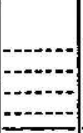 & $\begin{array}{r}2 \\
8 \\
3 \\
-\cdots \\
\end{array}$ & \begin{tabular}{|c|}
$\ldots \ldots .$. \\
\\
\hdashline \\
\hdashline \\
\hdashline
\end{tabular} & $\begin{array}{r}- \\
\hdashline \\
\hdashline\end{array}$ & & $\begin{array}{r}6 \\
11 \\
20 \\
16\end{array}$ & 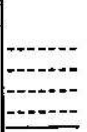 \\
\hline Beason..-- & & $\ldots \ldots$ & 10 & 36.5 & 24 & 46.2 & 8 & 16.4 & 1 & 1.0 & 52 & 100 \\
\hline $\begin{array}{l}\text { 46 inches: } \\
\text { First. } \\
\text { Eecond....... } \\
\text { Third } \\
\text { Fourth }\end{array}$ & & \begin{tabular}{|c|}
$-\ldots .$. \\
\hdashline$-\ldots$ \\
\hdashline
\end{tabular} & \begin{tabular}{r}
2 \\
1 \\
4 \\
\hdashline$-:$ \\
\end{tabular} & 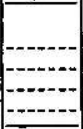 & $\begin{array}{r}11 \\
10 \\
9 \\
5 \\
\end{array}$ & 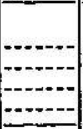 & $\begin{array}{r}6 \\
10 \\
3 \\
2 \\
\end{array}$ & 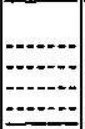 & \begin{tabular}{|c|}
$-\cdots$ \\
$-\cdots$ \\
\end{tabular} & & $\begin{array}{r}19 \\
21 \\
16 \\
7 \\
\end{array}$ & 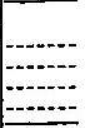 \\
\hline Segson. - & $=$ & $\ldots$ & 7 & 11.1 & 35 & 55.6 & 21 & 33.3 & $\ldots$ & $\ldots$ & 83 & 100 \\
\hline $\begin{array}{l}47 \text { inches: } \\
\text { First } \\
\text { Second } \\
\text { Third..... } \\
\text { Fourth..... }\end{array}$ & & & & $\mid$\begin{tabular}{c}
$-\cdots-1$ \\
\hdashline$-\cdots$ \\
\hdashline
\end{tabular} & $\begin{array}{r}8 \\
13 \\
7 \\
5 \\
\end{array}$ & 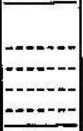 & $\begin{array}{l}7 \\
7 \\
6 \\
1 \\
\end{array}$ & 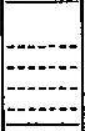 & $\begin{array}{r}1 \\
1 \\
\cdots\end{array}$ & 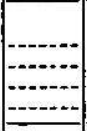 & $\begin{array}{r}15 \\
21 \\
15 \\
6 \\
\end{array}$ & 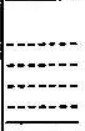 \\
\hline Besson.- & - & $\ldots \ldots$ & 2 & 3.5 & 88 & 57.0 & 20 & 35.1 & 2 & 3.5 & 67 & 100 \\
\hline 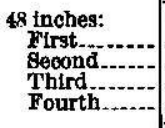 & 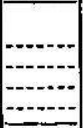 & & $\overline{1}$ & 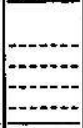 & $\begin{array}{r}6 \\
13 \\
1 \\
5 \\
\end{array}$ & 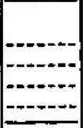 & $\begin{array}{r}10 \\
10 \\
9 \\
1 \\
\end{array}$ & 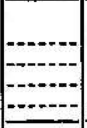 & \begin{tabular}{c|}
1 \\
1 \\
1 \\
- \\
\end{tabular} & \begin{tabular}{|c|}
$\ldots \ldots$ \\
\hdashline \\
\hdashline
\end{tabular} & $\begin{array}{r}17 \\
24 \\
12 \\
6\end{array}$ & 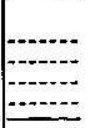 \\
\hline Season...- & $-\cdots$ & $\ldots$ & 1 & 1.7 & 25 & 42.4 & 30 & 50.8 & 3 & 5.1 & 59 & 100 \\
\hline $\begin{array}{l}49 \text { inches: } \\
\text { First. } \\
\text { Recond...... } \\
\text { Third... } \\
\text { Fourth. }\end{array}$ & (-יני & & $\begin{array}{c}-1 \\
-1 \\
\end{array}$ & - & \begin{tabular}{r}
6 \\
8 \\
1 \\
\hdashline \\
\end{tabular} & 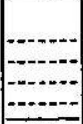 & $\begin{array}{r}10 \\
9 \\
8 \\
\end{array}$ & \begin{tabular}{|c|}
$-\cdots$ \\
\hdashline$-\cdots$ \\
$-\cdots$ \\
\end{tabular} & $\begin{array}{r}1 \\
1 \\
-2 \\
\end{array}$ & \begin{tabular}{|c|}
$\ldots \ldots$ \\
\\
\hdashline
\end{tabular} & $\begin{array}{r}17 \\
16 \\
1 \\
5 \\
\end{array}$ & 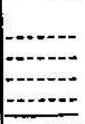 \\
\hline Serson -..- & --.--- & - & 1 & 2.6 & 12 & 30.7 & 22 & 56.4 & 4 & 10.3 & 39 & 100 \\
\hline 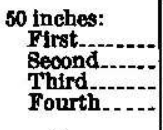 & י & 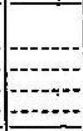 & & $\mid$ & $\mid \begin{array}{r}1 \\
-2 \\
\end{array}$ & 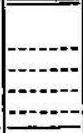 & $\begin{array}{r}10 \\
5 \\
2 \\
-\cdot- \\
\end{array}$ & \begin{tabular}{|c|}
$-\cdots$ \\
\hdashline$-\cdots$ \\
$-\cdots$ \\
\hdashline
\end{tabular} & \begin{tabular}{r}
3 \\
1 \\
\hdashline--- \\
\end{tabular} & 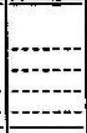 & $\begin{array}{r}17 \\
6 \\
2 \\
\end{array}$ & 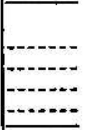 \\
\hline Beason.... & - & $+\cdots$ & $\ldots \ldots$ & $\ldots$ & 4 & 16.0 & 17 & 68.0 & 4 & 16.0 & 25 & 100 \\
\hline $\begin{array}{l}51 \text { inches: } \\
\text { F1rst..-.-. } \\
\text { Second...... } \\
\text { Third...... } \\
\text { Fourth..... }\end{array}$ & & & & $\mid$ & 1 & $\mid$\begin{tabular}{l}
$\mid \ldots . .$. \\
\hdashline \\
\hdashline
\end{tabular} & $\begin{array}{l}4 \\
8 \\
1 \\
1 \\
\end{array}$ & \begin{tabular}{|c|}
$--\cdots$ \\
$-y-$ \\
$-\cdots$ \\
\end{tabular} & $\begin{array}{c}1 \\
-1 \\
-\ldots\end{array}$ & 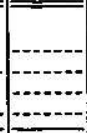 & $\begin{array}{l}\mathbf{6} \\
3 \\
2 \\
1 \\
\end{array}$ & 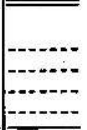 \\
\hline Beason. & $\ldots \ldots$ & $\ldots$ & & - & 1 & 8.3 & $\theta$ & 75.0 & 2 & 16.7 & 12 & 100 \\
\hline $\begin{array}{l}\text { All lengths: } \\
\text { Flirst } \\
\text { Becond.-. } \\
\text { Third } \\
\text { Fourth...... } \\
\end{array}$ & $\begin{array}{r}1 \\
6 \\
4 \\
\end{array}$ & 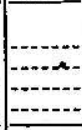 & $\begin{array}{l}10 \\
20 \\
64 \\
65 \\
\end{array}$ & $\mid$\begin{tabular}{ll}
$-\cdots-1$ \\
\hdashline-1
\end{tabular} & $\begin{array}{l}49 \\
64 \\
50 \\
33 \\
\end{array}$ & 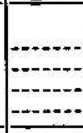 & $\begin{array}{r}53 \\
48 \\
23 \\
8 \\
\end{array}$ & \begin{tabular}{|c|}
$-\ldots .$. \\
\\
\hdashline
\end{tabular} & $\begin{array}{l}6 \\
4 \\
4 \\
\mathbf{2} \\
\end{array}$ & $\mid$ & $\begin{array}{l}118 \\
146 \\
147 \\
112 \\
\end{array}$ & \begin{tabular}{|c|}
$-\ldots \ldots$ \\
\\
\hdashline
\end{tabular} \\
\hline Season.... & 11 & 2.1 & 168 & 32.1 & 196 & 37.5 & 182 & 25.2 & 16 & 3.1 & 523 & 100 \\
\hline
\end{tabular}


TABLn 13.-Trade classification of ravo, salted, male sealskin with relation to over-all dimensions

[Based on pelts of 523 subadult male seals sampled at random between 18 June and 20 July 1946, on 8t. Paul Island; classifled by Harry Gladson in 1947. Dimensions are approximate]

\begin{tabular}{|c|c|c|c|c|}
\hline \multirow{2}{*}{ Trade classlfication (size) } & \multicolumn{2}{|c|}{ Length in inches } & \multicolumn{2}{|c|}{ Width in inches } \\
\hline & Minimum & Maximum & Minimum & Maximum \\
\hline $\begin{array}{l}\text { Small medfum } \\
\text { Medium } \\
\text { Large } \\
\text { Extra large- } \\
\text { Extra extrs large- }\end{array}$ & $\begin{array}{l}28 \\
301 / 2 \\
33 \\
351 / 2 \\
38\end{array}$ & $\begin{array}{l}341 / 2 \\
37 \\
391 / 2 \\
42 \\
441 / 2\end{array}$ & $\begin{array}{l}19 \\
201 / 2 \\
22 \\
231 / 2 \\
25\end{array}$ & $\begin{array}{l}24 \\
251 / 2 \\
27 \\
281 / 2 \\
30\end{array}$ \\
\hline
\end{tabular}

TABLE 14.-Trade classiffation of finished, dyed, male sealskin with relation to over-all dimensions

[Based on pelts of 523 subadult male seals sampled at random between 18 Jume and 20 Jt1ly 1946, on 8t. Paul Island; classifled by Harry Gladson in 1947. Dimensions are approximste]

\begin{tabular}{|c|c|c|c|c|}
\hline \multirow{2}{*}{ Trade classification (size) } & \multicolumn{2}{|c|}{ Length in inches } & \multicolumn{2}{|c|}{ Width in inches } \\
\hline & Mintmum & Maximum & Minimum & Maximum \\
\hline $\begin{array}{l}\text { Small medium } \\
\text { Medium } \\
\text { Iarge } \\
\text { Extra large- } \\
\text { Extra extra large. }\end{array}$ & $\begin{array}{l}351 / 2 \\
381 / 2 \\
411 / 2 \\
441 / 2 \\
471 / 2\end{array}$ & $\begin{array}{l}3916 \\
421 \\
451 \\
481 \\
5112 \\
15\end{array}$ & $\begin{array}{l}19 \\
201 / 2 \\
22 \\
251 / 2 \\
25\end{array}$ & $\begin{array}{l}23 \\
241 / 2 \\
26 \\
271 / 2 \\
29\end{array}$ \\
\hline
\end{tabular}

TABIS 15.-Length of ear from notch, by age and sex

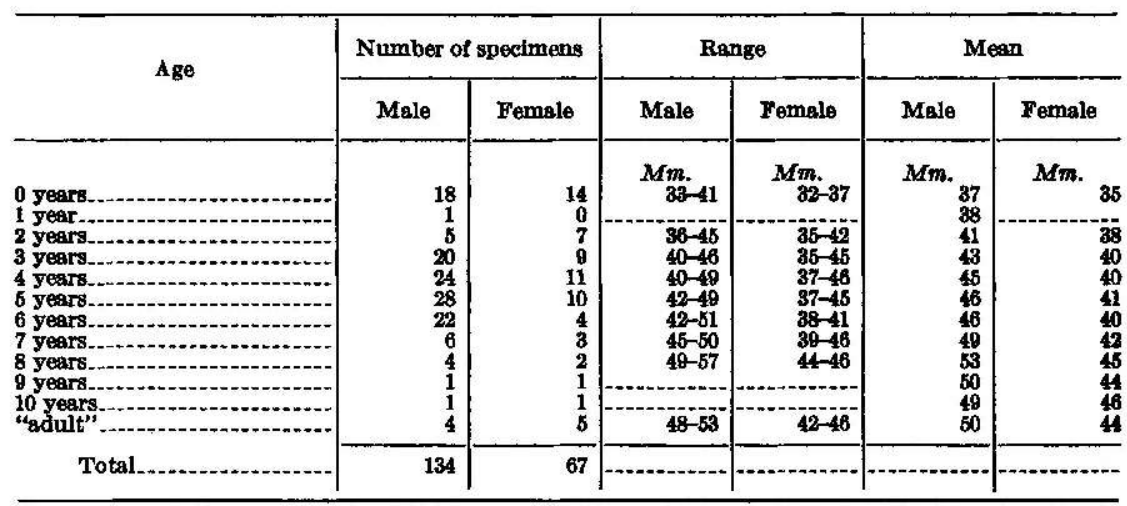


TABLE 16.-Field of oil from fur seals killed on St. Paul Island, Alaska, 1949 to 1958

[Source: U.S. Fish and Wildlife Service (1952-57) and unpublished dats]

\begin{tabular}{|c|c|c|c|c|c|c|}
\hline \multirow[b]{2}{*}{ Yesr } & \multicolumn{3}{|c|}{ From carcasses } & \multicolumn{3}{|c|}{ From skins } \\
\hline & $\begin{array}{c}\text { Number } \\
\text { of car- } \\
\text { casses } \\
\text { handled }\end{array}$ & $\begin{array}{l}\text { Yleld of } \\
\text { carcass } \\
\text { oll }\end{array}$ & $\begin{array}{l}\text { Yield of } \\
\text { carcess } \\
\text { oll per } \\
\text { carcass }\end{array}$ & $\begin{array}{c}\text { Number } \\
\text { of sealskins } \\
\text { handled }\end{array}$ & $\begin{array}{l}\text { Yield of } \\
\text { blubber } \\
\text { all }\end{array}$ & $\begin{array}{l}\text { Yleld of } \\
\text { blubber } \\
\text { oil per } \\
\text { akin }\end{array}$ \\
\hline $\begin{array}{l}1958 \\
1957 \\
1956 \\
1955 \\
1954 \\
1953 \\
1952 \\
1951 \\
1950\end{array}$ & $\begin{array}{l}59,570 \\
57,315 \\
93,300 \\
49,700 \\
49,850 \\
54,297 \\
50,935 \\
49,565 \\
\mathbf{4 7}, 800 \\
55,232\end{array}$ & $\begin{array}{r}\text { Gallons } \\
18,035 \\
118,000 \\
27,813 \\
12,771 \\
11,352 \\
15,180 \\
8,267 \\
12,165 \\
10,056 \\
14,830\end{array}$ & $\begin{array}{r}\text { Gallons } \\
0.33 \\
.81 \\
.30 \\
.26 \\
.28 \\
.28 \\
.16 \\
.25 \\
.21 \\
.27\end{array}$ & $\begin{array}{l}60,080 \\
61,244 \\
93,966 \\
50,803 \\
50,239 \\
54,995 \\
51,560 \\
50,573 \\
48,696 \\
57,445\end{array}$ & $\begin{array}{r}\text { Gallons } \\
33,400 \\
32,000 \\
60,464 \\
29,821 \\
30,044 \\
31,620 \\
28,138 \\
28,000 \\
31,957 \\
34,420\end{array}$ & $\begin{array}{r}\text { Gallons } \\
0.56 \\
.52 \\
.64 \\
.59 \\
.60 \\
.57 \\
.55 \\
.55 \\
.65 \\
.60\end{array}$ \\
\hline
\end{tabular}

1 Estimated. 



\section{APPENDIX A-COLOR NOTES}

Reproductions of the natural colors of seals or their pelts have rarely been published (Fortune, 1930; Schöps and Fritzsche, 1938; Scheffer and Kenyon, 1952). Thus, it seems desirable to place on record the fresh colors of the fur-seal pelage. The simple black pattern of the pup has already been described. In the following pages, color notes will be given for males and females representing the following classes: silver pup, yearling in autumn, 3-year-old (adolescent), and adult.

Colors were compared on St. Paul Island, unless otherwise noted, from living or freshly killed seals, pelage clean and dry (or moist), in sunlight whenever possible, with a Munsell Color Company (1954) soil color chart as reference. Bowers (1956) and Miller (1958) have pointed out the advantages of the Munsell system of color notation. The names used in the present paper, however, are not those given on the soil color chart, but rather the more widely used ISCC-NBS names (National Bureau of Standards, 1955, p. 15-31).

The pelage hues of the northern fur seal range from 5 YR to 10 YR, with two exceptions: (1) On tanned pelts, a dark reddish brown color (2.5 YR $2 / 4$ or 3/4) may appear. This is the color labeled by Maerz and Paul (1950, pl. 8) as "seal." It is next to "chocolate." "Seal" as a color name probably originated in the fur market from examination of tanned pelts. The color itself can often be seen in life near the bases of the flippers and around the teats and vestibular mucosa. As a matter of fact, the names "seal" and "seal brown" have been applied by artists and professional colorists to at least seven colors (National Bureau of Standards, 1955, p. 144-145). These colors range from dark reddish gray through moderate brown to dark olive brown. (2) The second exception is pale yellow (2.5 Y 8/4), seen on adult vibrissae and usually referred to as "white." The middle value in an array of 39 colors recorded for fur-seal pelage is light brown (7.5 YR 5/4)-an interesting but perhaps unimportant fact.

As a result of contact with rookery soil as well as excrement, urine, and regurgitated bile and milk, the coat of the seal invariably becomes stained. (Colors imparted by algal growths have been mentioned.) After patiently watching seals from a blind, Bartholomew $(1951$, p. 3$)$ concluded:

When the pregnant females flrst arrive on the breeding grounds they are pale silvery gray. Within 4 days of coming ashore they turn yellow-brown. Each time they go to sea they regain some of their grayness, and females who 
have made three trips to sea cannot, on the basis of color, be definitely distinguished from females who have just come ashore for the first time.

Similar color changes take place in the males, although their coloration is much more variable than that of the females. When they first come ashore, individual males will vary from light gray to almost black, but with each succeeding day ashore they become progressively more brown. One male, which when it was marked [tagged] was almost black, with a virtually white mane, after a week ashore became tan, with a yellow-brown mane.

In the present study, I have tried to select clean specimens for observation, though for certain individuals, especially silver pups, it has been difficult to distinguish between stain and true pelage color.

There is no strong evidence of graying (interference in the synthesis of melanin) with increasing age, except in the vibrissae, which are permanent hairs. As previously mentioned, these begin to turn white at the base, near the time of sexual maturity or a little later.

Up to the time of writing (1959), no diagnostic features of pelage or internal anatomy that might be used to identify American, as against Asian, fur seals have been discovered. The three main populations of Callorhinus ursinus breed, respectively, in eastern Bering Sea, western Bering Sea, and Sea of Okhotsk. (Perhaps 3,000 breed in the northern Kuriles, on the rim of the North Pacific.) Reproductive isolation in the three groups is rather complete, as indicated by the strong homing instinct of individual seals to the land of their birth. However, important numbers of seals from each group are known to mingle at sea in winter; American seals have been recovered on Soviet grounds, and vice versa. After careful study, Taylor and others $(1955$, p. 61-65) could find no evidence of pelage differences among the members of the three main populations.

\section{Silver Pup, Male}

I can distinguish a male from a female silver pup on the basis of genitalia, less surely on the basis of size and shape of canine teeth, and even less surely on the basis of body size. (In a sample of 173 pups weighed on 4 October 1947 , the mean weight of males was 13.9 kg., the mean weight of females $12.0 \mathrm{~kg}$.) I cannot see any differences in the color pattern of male and female silver pups, or even of autumn yearlings, in the second adult-type pelage. Nevertheless, in view of the possibility that slight differences do exist, I have reported separately on the color pattern for each sex.

\section{DORSAL ASPECT}

Top of snout light grayish brown (10 YR 7/3); upper lip also light grayish brown; forehead brownish gray (10 YR 4/1); cheeks light grayish brown (10 YR 7/3); region around eyes brownish gray 
(10 YR 3/1), in strong contrast to paler cheek stripes; crown brownish gray (10 YR 4/1); ears brownish gray (10 YR 3/1) with slightly worn tips; neck, shoulders, back, rump, and tail brownish gray (10 YR 4/1); no mane; rump patches (prominent) and flanks brownish pink (7.5 YR 7/2); bases of flippers, dorsal and ventral, dark grayish brown (5 YR 2/2). Light-brown color of belly extends upward and along sides into armpit, visible from dorsal aspect.

\section{VENTRAL ASPECT}

Lower lip and chin brownish pink (7.5 YR 7/2); lower lip stained brownish, probably from bile; throat brownish gray (10 YR 4/1). (Some silver pups have a continuous bright silver throat and anterior chest region, without the dark band of the throat as in the present specimen.) Chest, anterior region, brownish pink (7.5 YR 7/2); chest, posterior region between flippers, and belly, anterior region, brownish gray (10 YR 3/1); belly, posterior region, light brown (5 YR 6/3); around penial opening grayish brown (5 YR 4/2); armpits very bright, brownish pink (5 YR 7/2).

Specimens: Principal specimen, age 8-10 weeks; killed 24 September (24-9-58 B). Three others, killed 13 October-17 November; BDM 187, BDM 188, BDM 184.

\section{Silver Pup, Female}

\section{DORSAL ASPECT}

Top of snout light yellowish brown (10 YR 6/3) ; upper lip dark yellowish brown (10 YR 3/3), fading to color of cheeks, which are light grayish brown (10 YR 7/3); region around eyes brownish gray (10 YR 3/1) ; ears dark grayish yellowish brown (10 YR 3/2), slightly worn at tips; forehead, crown, back of neck, shoulders, back and rump brownish gray (10 YR 4/1); rump patches prominent, light brownish gray (10 YR 6/1); tail (dorsal) brownish gray (10 YR $4 / 1)$; flanks mostly like belly, light grayish brown (10 YR $7 / 3)$; bases of flippers (dorsal and ventral) dark grayish yellowish brown (10 YR 2/2).

\section{VENTRAL ASPECT}

Lower lips and chin at corners of mouth like top of snout, slight yellowish brown (10 YR 6/3), but at anterior tip stained darker, grayish brown (7.5 YR 3/2); throat brownish gray (10 YR 4/1); chest, anterior region, light grayish yellowish brown (10 YR $7 / 2)$; chest, posterior region between flippers, grayish yellowish brown (10 YR 4/2); armpits brownish pink (7.5 YR 7/2), except for narrow 
zone near flippers, where moderate yellowish brown (10 YR 5/3); belly, anterior region, light brown (5 YR 6/3) ; belly posterior region, light grayish yellowish brown (10 YR 7/2); tail, ventral surface, brownish gray (10 YR 4/1); location of mammary teats not visible.

Specimens: Principal specimen, age 8-10 weeks; killed 28 September (28-9-58 A). Three others, killed 13 October-17 November; BDM 185 ; BDM 186 ; BDM 189.

\section{Yearling, Autumn, Male}

\section{DORSAL ASPECT}

Top of snout light brownish gray (10 YR 6/1); upper lip light grayish yellowish brown (10 YR 7/2); forehead light brownish gray (10 YR 5/1); cheeks light grayish yellowish brown (10 YR 7/2); region around eyes brownish gray (10 YR 4/1); crown light brownish gray (10 YR 5/1); ears grayish yellowish brown (10 YR 4/2); back of neck (no mane), shoulders, back, and rump light brownish gray (10 YR 5/1); rump patches not conspicuous (though conspicuous on certain other yearling males), light yellowish brown (10 YR 6/2); tail, dorsal, dark grayish yellowish brown (10 YR 2/1); flanks shading into color of belly, visible well up along sides; bases of flippers, dorsal and ventral, grayish brown (5 YR 3/2).

\section{VENTRAL ASPECT}

Lower lip and chin light yellowish brown (10 YR 6/3); throat brownish gray (10 YR 4/1); chest, anterior region, light grayish yellowish brown (10 YR 7/2); chest, posterior region between flippers, grayish brown (7.5 YR 4/2); arm pits moderate brown (5 YR 4/3); belly, anterior region, grayish brown (7.5 YR 4/2); belly, posterior region, light grayish yellowish brown (10 YR 7/2), stained brownish posterior to penial opening; tail, ventral, grayish brown (5 YR 3/2), with black margins.

Specimens: Principal specimen killed 26 September (26-9-58 A). Sixteen others killed 13 September-5 November (27-9-58 B, BDM nos. $7,8,14,15,21-24,290$, and 512-517).

\section{Yearling, Autumn, Female}

\section{DORSAL ASPECT}

Top of snout and upper lip light brown (7.5 YR 5/4); cheeks light yellowish brown (7.5 YR 7/4); narrow region around eyes grayish brown (7.5 YR 3/2); outward of this brownish gray (10 YR 3/1); ears moderate brown (7.5 YR 4/4), rubbed bare at tip; forehead, a circular region of grayish brown (7.5 YR 3/2) ; crown, back of neck, 
shoulders, back and rump brownish gray (10 YR 3/1); rump with conspicuous patches of light brownish gray (10 YR 6/1); tail, dorsal, dark grayish yellowish brown (10 YR 2/1); flanks intermediate color between back and belly, appearing light-colored from above; bases of flippers, dorsal and ventral, dark grayish yellowish brown (10 YR 3/2).

\section{VENTRAL ASPECT}

Lower lip light brown (7.5 YR 5/4); chin and throat brownish gray (10 YR 4/1); chest light grayish yellowish brown (10 YR 7/2); belly brownish pink (7.5 YR 7/2); tail, ventral, dark grayish yellowish brown (10 YR 2/1).

Specimens: Principal specimen killed 3 October (3-10-58 A). Four others killed 27 October-23 November (BDM nos. 16, 25, 26, and 29).

\section{Three-year-old, Adolescent Male (Bachelor)}

\section{DORSAL ASPECT}

Top of snout and upper lip light yellowish brown (10 YR 6/3); upper lip palest at corner of mouth, under eye, and darker toward muzzle; cheeks also light yellowish brown; region around eyes grayish yellowish brown (10 YR 5/2); ears grayish yellowish brown (10 YR 4/2), not worn at tips, followed posteriorly by faded streak; forehead to rump brownish gray (10 YR 4/1); crown with an area about $6 \mathrm{~cm}$. in diameter in which the guard hairs are longer $(28 \mathrm{~mm}$.) than those surrounding $(15 \mathrm{~mm}$.) and are erect or slightly recurved; rump patches faintly suggested; tail, dorsal, dark grayish yellowish brown (10 YR 2/1); flanks, transition color between back and posterior region of belly; bases of flippers, dorsal and ventral, dark grayish yellowish brown (10 YR 2/2).

\section{VENTRAL ASPECT}

Lower lip and chin moderate yellowish brown (10 YR 5/3); throat brownish gray (10 YR 4/1); chest, anterior region, light yellowish brown (10 YR 6/3); chest, posterior region between flippers, grayish brown (7.5 YR 3/2); armpits moderate brown (5 YR $3 / 4$ ) ; belly, anterior region, grayish brown (5 YR 3/2), shading gradually into color of belly, posterior region, light yellowish brown (10 YR 6/3); tail, ventral, brownish gray (5 YR 3/1).

Specimens: Principal specimen killed 27 September (27-9-58A). Ten others killed 22 June-19 July (BDM nos. 60, 67, 70, 72, 73, 77-79, 83, and 87). 


\section{Three-year-old, Adolescent Female (Young Cow)}

\section{DORSAL ASPECT}

Top of snout grayish brown (7.5 YR 4/2); upper lip light yellowish brown (10 YR 6/3); forehead brownish gray (10 YR 4/1); cheeks moderate yellowish brown (10 YR 5/3); region around eyes brownish gray (10 YR 3/1); crown brownish gray (10 YR 4/1); ears grayish yellowish brown (10 YR 4/2), worn and blackish at tips; back of neck, shoulders, back and rump brownish gray (10 YR 4/1). Flanks are colors in transition from back to belly. Tail, dorsal, and bases of all flippers, all surfaces, dark grayish yellowish brown (10 YR 2/2).

\section{VENTRAL ASPECT}

Lower lip and chin moderate yellowish brown (10 YR 5/3); throat brownish gray (10 YR 4/1); chest, anterior region, light yellowish brown (10 YR 6/3); chest, posterior region between flippers and belly, anterior region, grayish brown (7.5 YR 3/2); belly, posterior region, moderate brown (7.5 YR 4/4); location of mammary teats not visible; vestibular mucosa dark brownish gray to black, with narrow rim of dark reddish brown hair (2.5 YR 2/4); tail, ventral, dark grayish yellowish brown (10 YR 2/2).

Specimens: Principal specimen killed 24 September (24-9-58 A). Three others killed 23 March-15 September (NWC 52-3048, BDM 287, and BDM 410).

\section{Adult Male (Bull)}

\section{DORSAL ASPECT}

Top of snout and upper lip grayish yellowish brown (10 YR 5/2); forehead, cheeks, and region around eyes grayish yellowish brown (10 YR 4/2); crown and ears dark grayish yellowish brown (10 YR $3 / 2$ ) ; crown with longer hairs ("wig") same color as surroundings; ear tips worn bare, nearly black; back of neck (mane) light yellowish brown (10 YR 7/4), faintly parted (divergence line) into right and left sides by the paired neck muscles, longest hairs $70 \mathrm{~mm}$.; shoulders and back gradually changing from grayish yellowish brown (10 YR 4/2) to dark grayish yellowish brown (10 YR 3/2); rump and upper surface of tail dark grayish brown (5 YR 2/2) ; flanks grayish yellowish brown (10 YR 4/2); bases of all flippers, upper and lower surfaces, dark reddish brown (2.5 YR 2/4). 


\section{VENTRAL ASPECT}

Lower lip and chin grayish yellowish brown (10 YR 4/2); throat, chest, and belly grayish brown (7.5 YR 3/2); penial opening not marked by color change; tail, ventral surface, nearly naked, grayish.

Specimens: Principal specimen at least 15 years old, teeth worn or missing, killed 19 September (19-9-58 A). Nine other bulls killed 25 June-5 July, all 7-year-olds or older (age 7, BDM nos. 251-255; age 8, BDM nos. 302-303; age 9, BDM 319; "adult", BDM 75). Many other known-age males between ages 3 and 7 have been examined.

\section{Adult Female (Old Cow)}

\section{DORSAL ASPECT}

Top of snout light brown (7.5 YR 5/4); upper lip moderate brown (7.5 YR 4/4); forehead grayish brown (7.5 YR 3/2); cheeks moderate brown (7.5 YR 4/4); region around eyes grayish brown (7.5 YR $3 / 2$ ) ; crown grayish brown (7.5 YR 4/2); ears light brown (7.5 YR 5/4) along two-thirds of length, bare and blackish on tip; back of neck grayish brown (7.5 YR 4/2) with a suggestion of a lighter, grayer color on crown and mane; shoulders, back and rump grayish brown (7.5 YR 3/2); tail, dorsal, dark grayish yellowish brown (10 YR 2/2); flanks light brown (7.5 YR 5/4), lightening toward armpit and darkening toward hind flipper; bases of flippers, dorsal and ventral, dark grayish brown (5 YR 2/2).

\section{VENTRAL ASPECT}

Lower lip, chin, and throat grayish brown (7.5 YR 3/2); chest, anterior region, light grayish brown (7.5 YR 5/2); chest, posterior region, grayish brown (7.5 YR 3/2); armpits moderate brown (5 YR 4/4); belly, grayish brown (5 YR 3/2); mammary teats not visible, their location marked by a few gray hairs; vestibular mucosa wrinkled, dark brownish black, surrounded by a thin line of dark reddish brown (2.5 YR 2/4); tail, ventral, also dark reddish brown.

Specimens: Principal specimen killed 25 September (25-9-58 B). Eight others killed 13 March-11 September; all 7-year-olds or older (age 7, BDM nos. 276, 279; age 8, BDM nos. 324 and 349 ; age 10 , BDM 404; age over 10, SITKA 50-25, SITKA 50-34, NWC 523029). Many other females between ages 3 and 7 have been examined; also many females recorded simply as "adult." 



\section{APPENDIX B-GLOSSARY}

For textbook-style illustrations of the structure of hair and skin, see Auber (1952), Chase (1954), Hamilton (1951), Hausman (1939, 1944), Miller (1952), Montagna (1956), Odland (1954), Parnell (1951), and Wildman (1954).

Awn.-(See guard hair.)

Bachelor.-Colloquially, a male seal of any age between 2 and 6 years, inclusive. Thus, a pup born in summer 1950 became a "yearling" on 1 January 1951, a "bachelor" on 1 January 1952, and a "bull" on 1 January 1957.

Birthcoat-Pelage of the black pup, newborn.

Blastocyst (blastula).-An early stage of the embryo when the cells are arranged in a single layer to form a hollow sphere, barely visible to the naked eye.

Blubber (panniculus adiposus).-The thick stratum of yellowish or whitish, fatty connective tissue which underlies the skin of most marine mammals.

Bulb.-Swollen base where hair root and hair follicle are indistinguishable. Bull-Colloquially, a male seal older than 6 years. (See bachelor.)

Cast-A negative impression, in a sheet of plastic film or gelatin, of part of the surface of a flber.

Club hair-An inactive, mature hair with characteristic shrunken, rather than bulbous, base.

Connective tissue sheath.-An especially heavy sheath surrounding the outer root sheath of the vibrissa. The connective tissue sheath serves for attachment of erectile muscles.

Cortex-Main substance of the hair, situated between the outer cuticle and the central medulla; usually pigmented; consisting of dead, keratinized cells.

Cow.-Colloquially, a female seal older than a jearling. Thus, a pup born in summer 1950 became a "yearling" on 1 January 1951 and a "2-year-old cow" on 1 January 1952.

Cuticle-A single layer of translucent cells on the surface of the hair. The cells are attached at one end, with their thin free margins pointing toward the tip of the hair. In the fur seal, the cuticle is less than 1 micron thick.

Cuticular-scale pattern.-Various nomenclatures have been proposed, depending upon shape of the visible portion of the scale, degree of overiap, and form of external margins. See Wildman (1954) for diagrams and photographs of coronal, diamond-petal, and other patterns.

Dermis (derma, corium).-The thickest and most elaborate stratum of the skin (representing, in the fur seal, about 99 percent of its thickness), lying between the epidermis and the blubber, consisting largely of connective tissue surrounding the hair roots and the sweat and sebaceons glands.

Epidermis. -The thin surface layer of skin, consisting of two main parts: a superficial stratum corneum of dead, translucent cells and a deeper stratum malpighil of active, deeply staining cells. At the site of each hair follicle, the two layers dip deeply into the dermis. 
Fiber.-As used in this work, a hair of any kind, including a vibrissa.

Follicle.-A cylindrical sleeve or pouch, representing an invagination of the outer skin, in which the hair grows. It is swollen at the base into a bulb.

Follicular bundle (common follicular bundle, common hair bundle).-A group of follicles, each distinct at its base (bulb) but coalescing near the surface of the skin. Near the surface of the adult skin, the follicular bundle contains a guard hair, 35-40 underfur fibers, sweat duct, and 2 sebaceous ducts, all surrounded by a thick, conspicuous sheath (the outer root sheath).

Germ (germ plate, hair germ).-Matrix cells which remain below the hair follicle, at the tip of the papilla, in the resting stage between molts. They initiate growth of a new hair at regular intervals.

Guard hair (shield hair, awn hair, overhair).-A fiber of the outer coat of the Juvenile and adult; largest, thickest, and most deeply rooted of the pelage fibers; distinctly pigmented and medullated along most of the shaft; expanded toward the tip into a blade. (Certain of the largest ones, appearing widely spaced in Iongitudinal rows on the fetus, might be called guide hairs, or "Leithaare".)

Hair.--The hair is divided regionally into root and shaft; structurally into cuticle, cortex, and medulla (which see). So far as known, all hairs of the adult fur seal, except the vibrissae, are replaced annually by new halrs originating on the sites of their predecessors.

Horizontal section (tangential section).-A section cut in a plane parallel to the surface of the skin. Since the pelage fibers emerge at a siant, they rarely appear as true circles in a horizontal section of skin.

Lanugo.-The fine hair on the body of the fetus.

Matrix.-Base of the root bulb where the cells are most actively dividing to form the hair.

Median section.-A section made in the plane which divides the body symmetrically into right and left halves. In a true median section of hair from the middle of the back, for example, the entire length of the hair can be seen.

Medulla.-Pith of the hair; a series of gas-fllled cells along the axis of the shaft; present only in guard hairs and largest underhairs. See Wildman (1954) for classification of medullary patterns.

Melanocyte.-A cell in the root of the hair follicle, or elsewhere, which manufactures a yellowish brown pigment; melanin. Concentrated melanin appears black.

Micron.-A unit of measurement: $0.001 \mathrm{~mm}$, or 0.000039 inch.

Molt.-Replacement of an older crop by a newer crop of fur and hair fibers. In the fur seal, the first molt (in late summer) results in a qualitatively different population of fibers. Each subsequent annual molt, prolonged over a period of 4-5 months in autumn, results in a similar, though newer, population.

Munsell color notation.-( See Appendix A and Literature Cited.)

Otariid (eared seal).-Anglicized name for any fur seal or sea lion of the family Otarifdae, including 7 genera (Scheffer, 1958).

Palmar.--Pertaining to the palm.

Panniculus adiposus.-( See blubber.)

Panniculus carnosus.-A discontinuous thin sheet of muscle underneath the blubber. When a sealskin is stripped forcibly from the body, large patches of the panniculus carnosus remain with the skin.

Papilla.-A cone of connective tissue, continuous with the dermis, which rises into the bulb of the follicle.

Parchment cure.-Method of preserving a sealskin by stretching it on a hoop and allowing it to dry. 
Parous-Having borne one or more young.

Phocid (hair seal, earless seal, true seal).-Anglicized name for any seal of the family Phocidae, including 13 genera.

Pilary system.-The pelage, including the hidden roots and nourishing struetures of the fibers as well as their visible shafts.

Pilosebaceous.-Pertaining to the hair and its sebaceous gland or glands. In the fur seal, the guard hair with follicle and pair of sebaceous glands compose a pilosebaceous unit. The hair emerges through a pilosebaceous funnel and orifice. A bundle of underfur fibers emerges through the same funnel and orifice.

Plantar.--Pertaining to the sole.

Pore--On hairless skin, the opening of a sweat gland; on unhaired skin or leather, the pilosebaceous orifice.

Prime-A pelt is prime when molt is complete, that is, when new fibers have ceased to grow in length; pigment is no longer being formed in the root; and old fibers have been pushed out or shed.

Primordium.-An embryonic hair follicle first visible as a thickening of the epidermis.

Pup.-A young seal up to about age 6 months, or arbitrarily to 31 December of the year of birth. In the present report, pups are classified as "black pup, newborn"; "black pup, molting"; and "silver pup."

Rhinarium.-Naked area of roughened skin at the tip of the snout.

Roadskin.-Colloquial term applied on the Pribilof Islands to a seal in shock from overheating or exhaustion; also to its skin.

Root.-The basal (proximal) portion of the hair which is buried in the skin and is surrounded by 1-3 sheaths. Near the deepest part of the root, the hair matrix (living) becomes the hair (dead).

Root sheath.-The outer root sheath is a pouch-like continuation of the epidermis which surrounds the follicle, except at its extreme base, where the papilla enters. The inner root sheath originates in the bulb of the follicle and extends part way up the root of the hair, interlocking with the cuticle of the hair. (See also connective tissue sheath.)

Scale.-( See cuticle.)

Sebaceous gland.-A gland secreting an oily hairdressing known as sebum. Twin glands are associated with each follicular bundle in the juvenile as well as in the adult pelage. Each gland secretes independently through an exit near the base of the guard-hair shaft.

Shaft--The free portion of the hair. At its basal (proximal end, the shaft may free itself of the root sheath a short distance below the level of the epidermis. At its terminal (distal) end, it tapers to a sharp tip.

Stage.-Colloquially, a pelt is said to be "stagy", or going through a stage, when it is molting; especially when dark pigment flecks can be seen on the buffed side of the pelt.

Stratum.-(See epidermis.)

Sweat gland.-A sweat gland of the apocrine type originates beneath and beside each guard hair, and empties into the pilary funnel above the exit of the sebaceous glands. See Woolard (1930) for distinction between the small, ordinary, superficial eccrine glands of man and the large, deep apocrine glands of man and lower animals.

Tels subcutanea-A filmy layer of connective tissue, often difficult to distinguish, which binds the panniculus adiposus or panniculus carnosus to the body. 
Tooth ridge.-Dentin is deposited unequally in winter and summer on the root of the fur-seal tooth. The resuit is a series of concentric, alternate, ridges and valleys which may be counted on the surface of the root up to about age 10 to 12 years.

Underfur fiber (underfur hair).- - One of the fibers of the undercoat of the adult-type pelage; first seen in mature form when the pup has reached an age of about 6 months; always in bundles of 35 to 40 ; nonpigmented; nonmedullated, wavy ; varying but little in cross-section shape and diameter along its length.

Underhair.-A flber of the undercoat of the pup; shortest, thinnest, and most superficially rooted of the juvenile pelage fibers; faintly pigmented; usually nonmedullated; varying but little in cross-section shape and diameter along its length.

Vellus.-A coating of fine, temporary hairs such as those on top of the flippers of the fur-seal fetus.

Vibrissa (sinus hair, tactile hair, whisker).-An elaborate sensory bristle, much larger than any body hair, situated on either side of the gnout (mystacial) and above each eye (superciliary).

Yearling.-(See bachelor.) 


\section{PLATES}





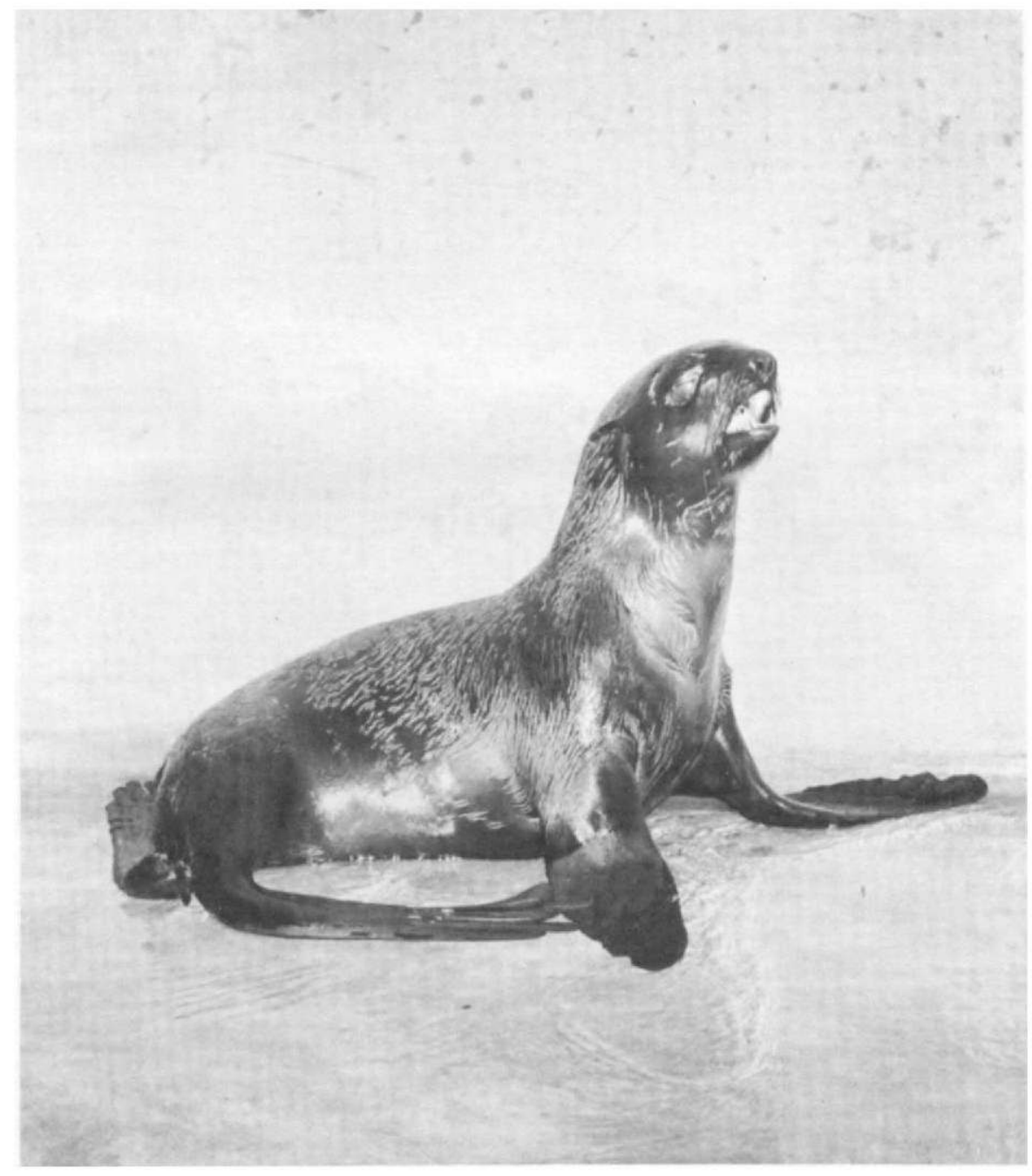

Plate 1.-Wet pelage of subadult male in San Diego Zoo. Water parts the tips of the guard hairs into silvery streaks but does not penetrate to the base of the underfur. (San Diego Zoo photo by R. Van Nostrand) 

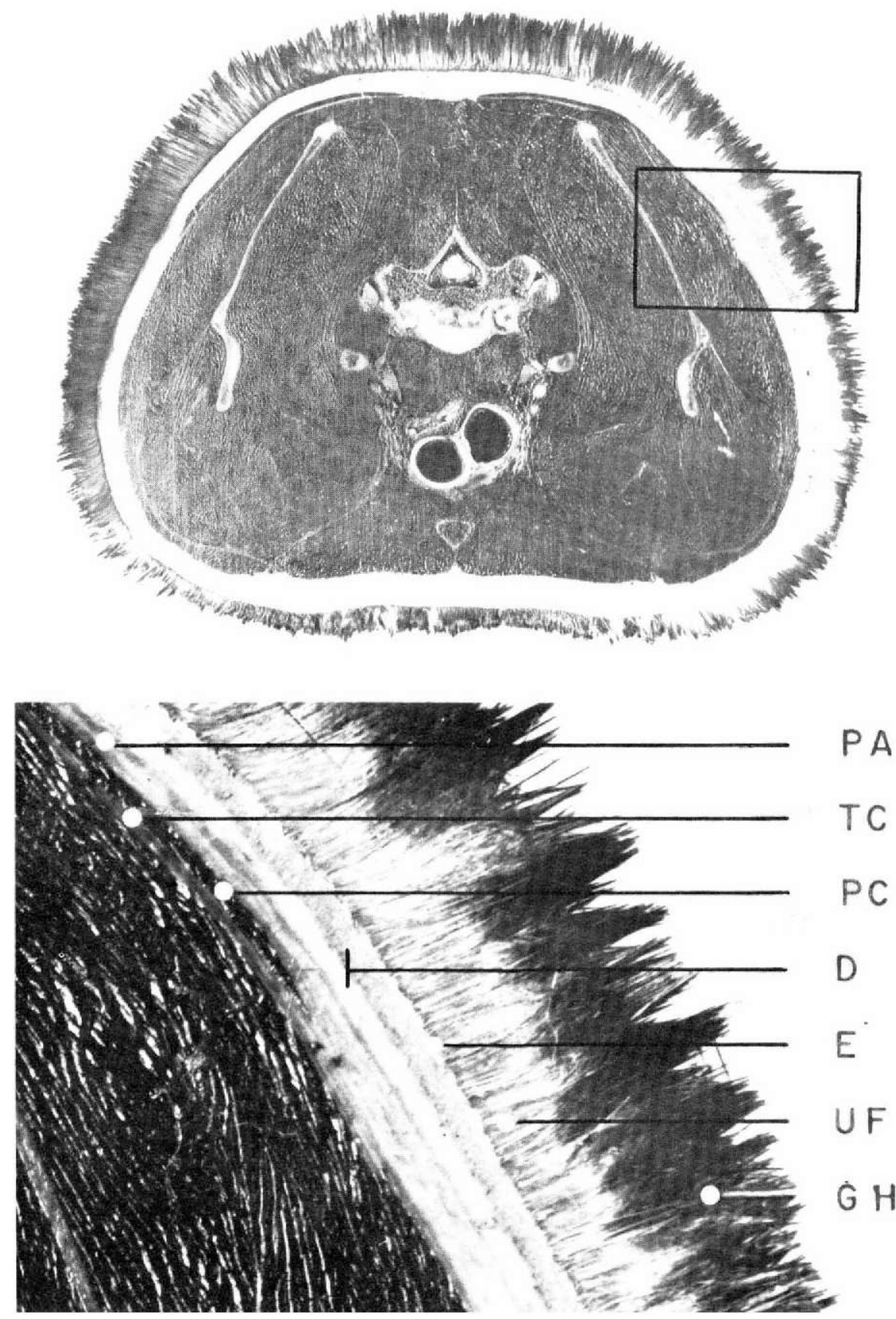

Plate 2.-Cross section of subadult male showing pelage relations; posterior face of section at level of bronchi ; flesh frozen; pelage damp; $\times 1 / 2$ (above) and $\times 21 / 2$ (below). GII-guard hairs; UF-underfur hairs; $\mathrm{w}$-epidermis; D-dermis of two indistinct zones, the darker one containing the hair roots; $\mathbf{P A}$-panniculus adiposus ; $\mathrm{PC}-$-panniculus carnosus; TC-tela subcutanea.

$(3037-9)$ 

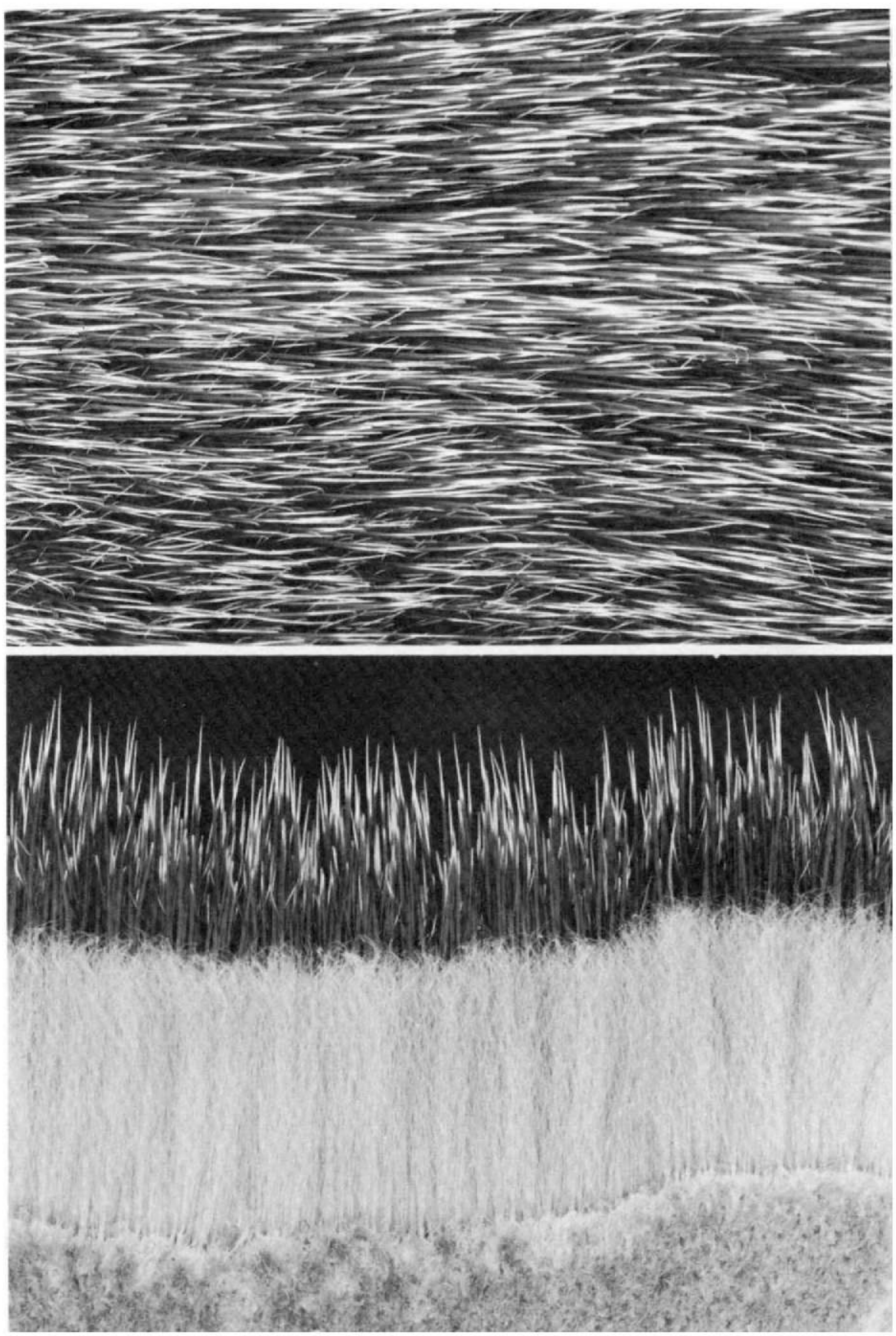

Puate 3.-Tanned pelt of subadult male showing pepper-and-salt effect of whitetipped guard hairs. (Above) Outer surface; anterior end at left; $\times 4$. (Below) Inner surface, with guard hairs extending beyond wooly underfur fibers; leather at bottom of photo; $\times 4$. (1285 and $1292 \mathrm{~A}$ ) 


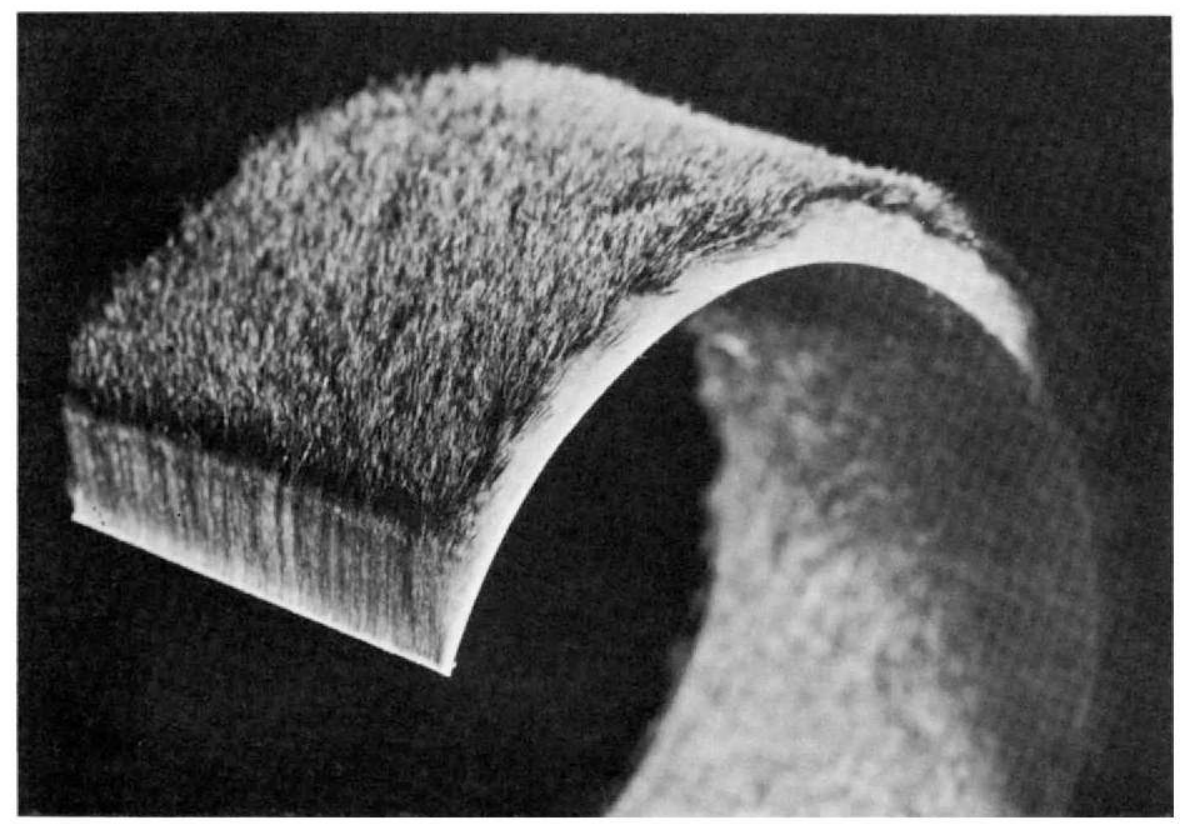

Plate 4-A.-Strip of parchment-cured pelt from back of subadult male; 12 July; natural size.

(3978)

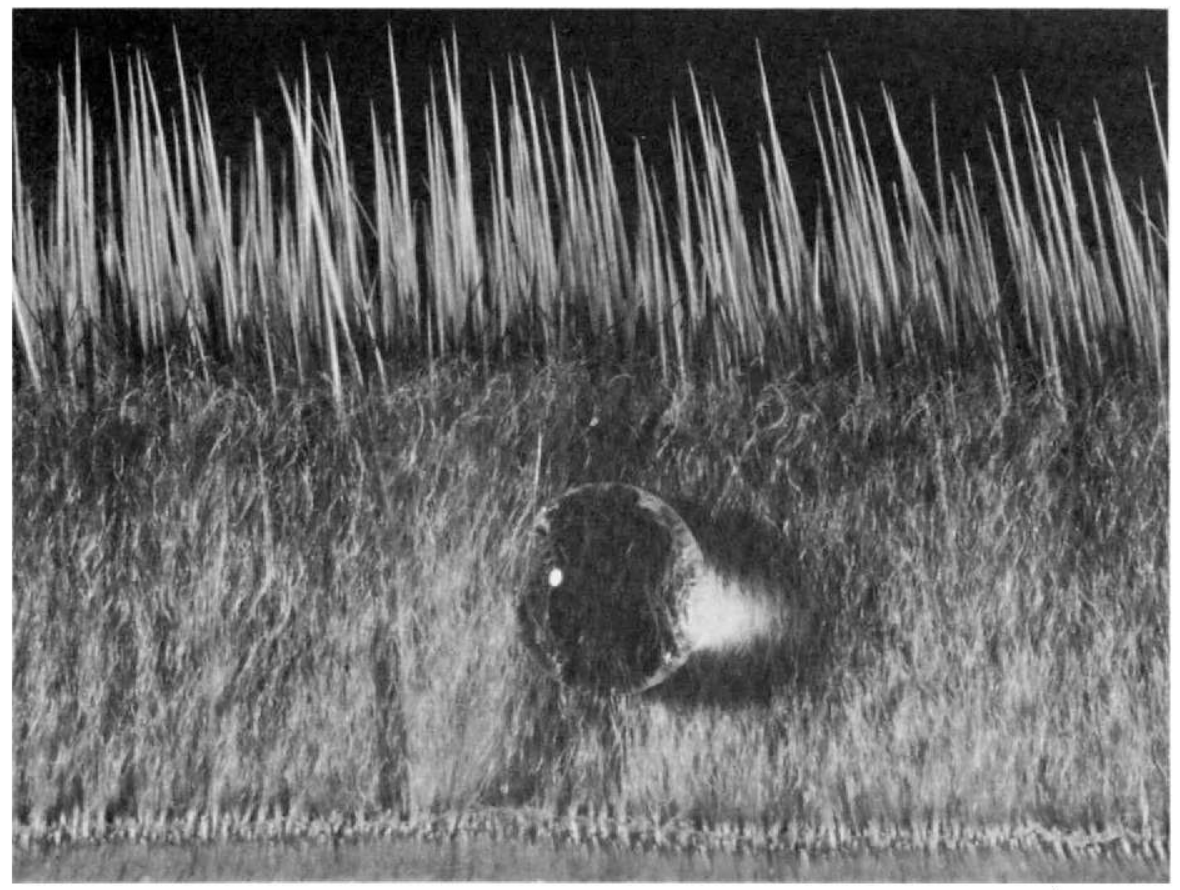

Prate 4-B.-Freshly cut section of pelt of yearling with drop of water placed on underfur to demonstrate its water-repellent nature; 7 September; $\times 4$.

(4063) 


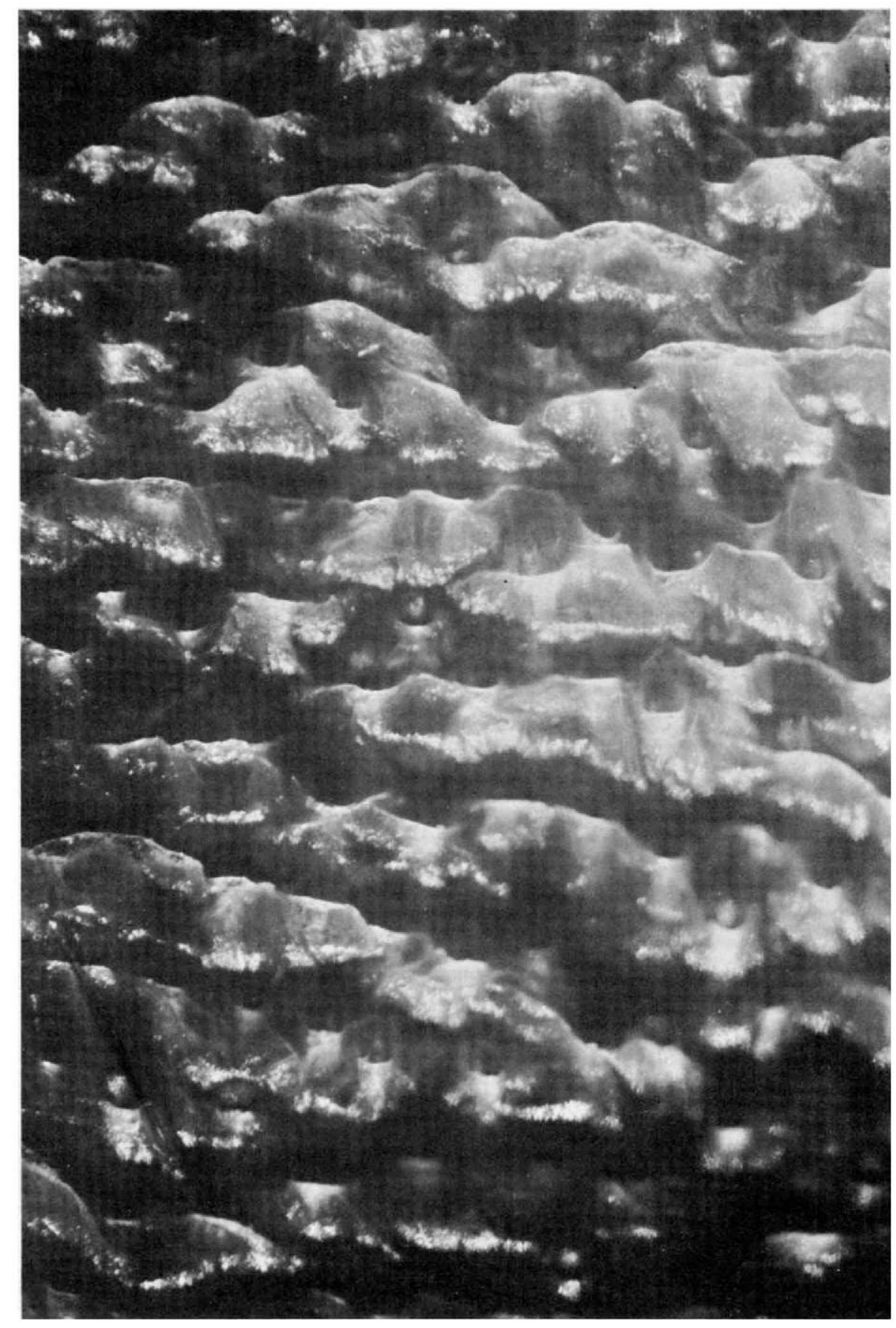

Plate 5.-Scaly appearance of epidermis from back of subadult male; 12 July ; skin sample parchment-cured; later macerated 20 days in warm water; plucked; hardened in formalin; illuminated from anterior end (top) ; photographed in moist condition : $\times 40$.

(4212) 


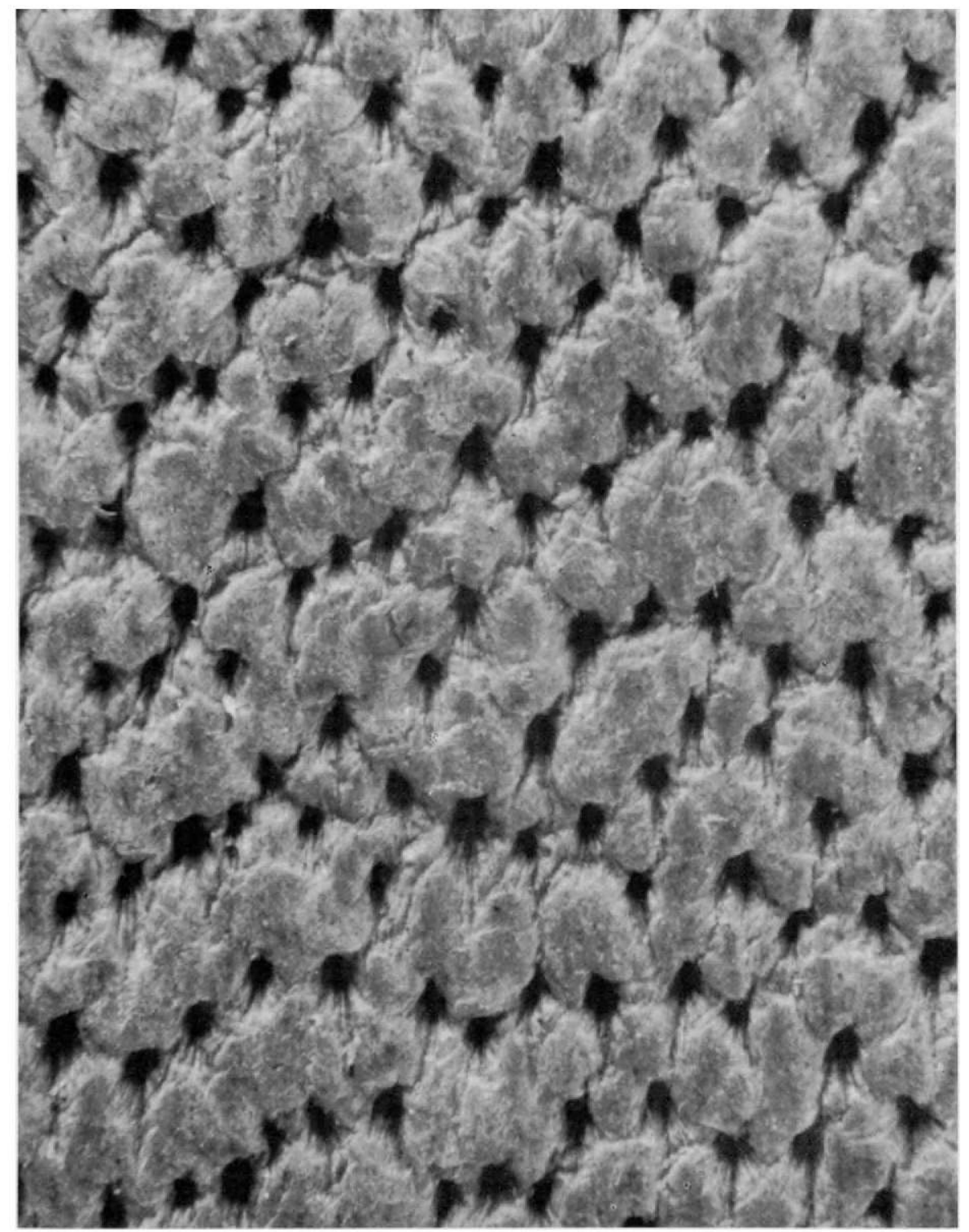

Puate 6.-Surface of suede-tanned leather from back of neck of 5-year-old female, showing distribution of pilosebaceous oriflces, or "pores." A bundle including 1 guard hair and 35 to 40 underfur hairs was withdrawn in the tanning process from each pore. Anterior end of body toward top of photo; $\times 40$. 


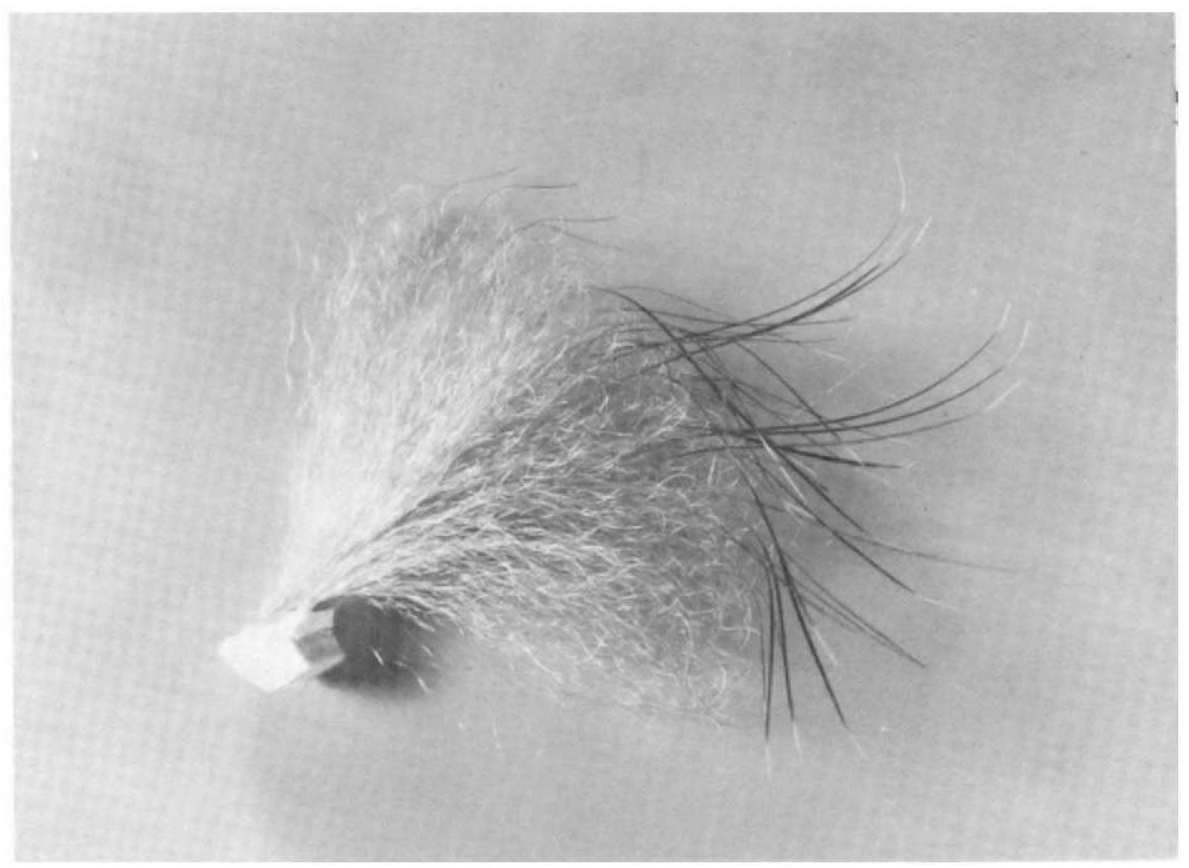

Plate 7-A.-Small square of parehment-cured pelt from back of subadult male. Lateral view ; $\times 4$.

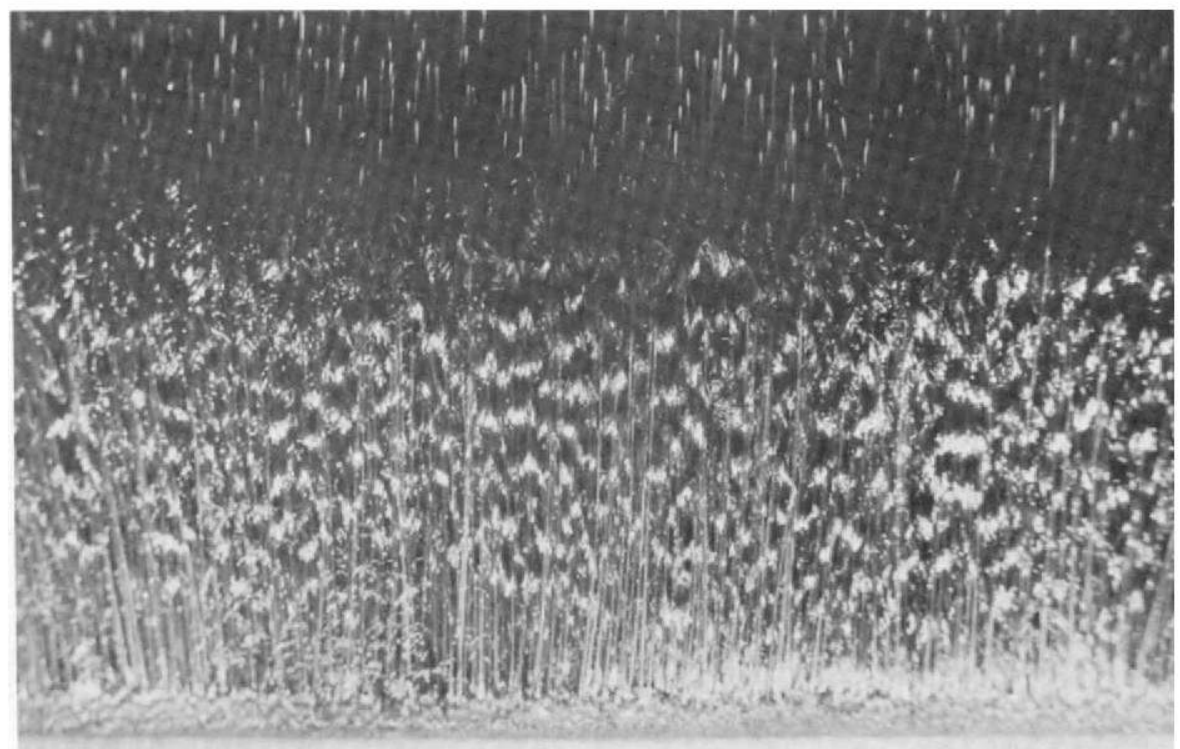

Plate 7-B.-Transverse section of pelt from rump of adult female showing natural waves in underfur; fibers held together with tritolyl phosphate; anterodorsal view ; $\times 3$.

(3985) 


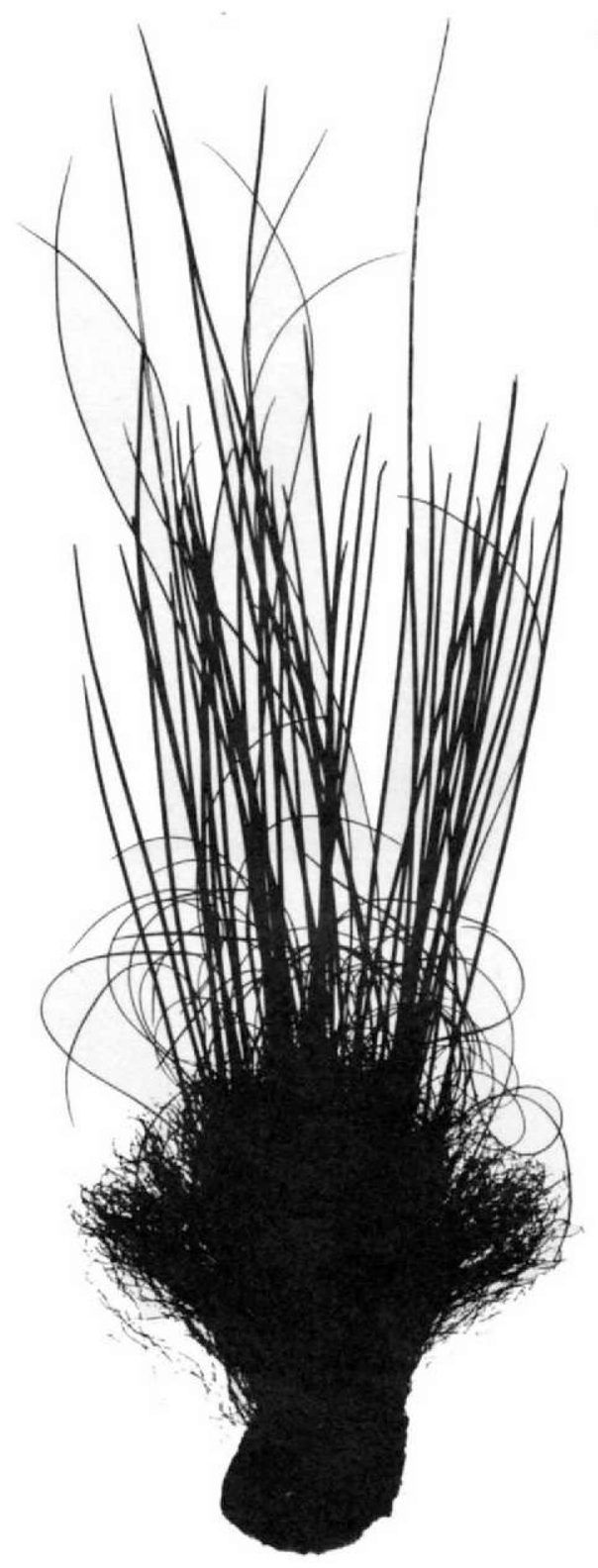

PLATE 8.-Silhouette of bit cut from tanned skin of neck of 9-year-old male, showing underfur fibers, ordinary guard hairs, and long guard hairs (mane hairs) ; $1 \mathrm{July}$; $\times 2$. 


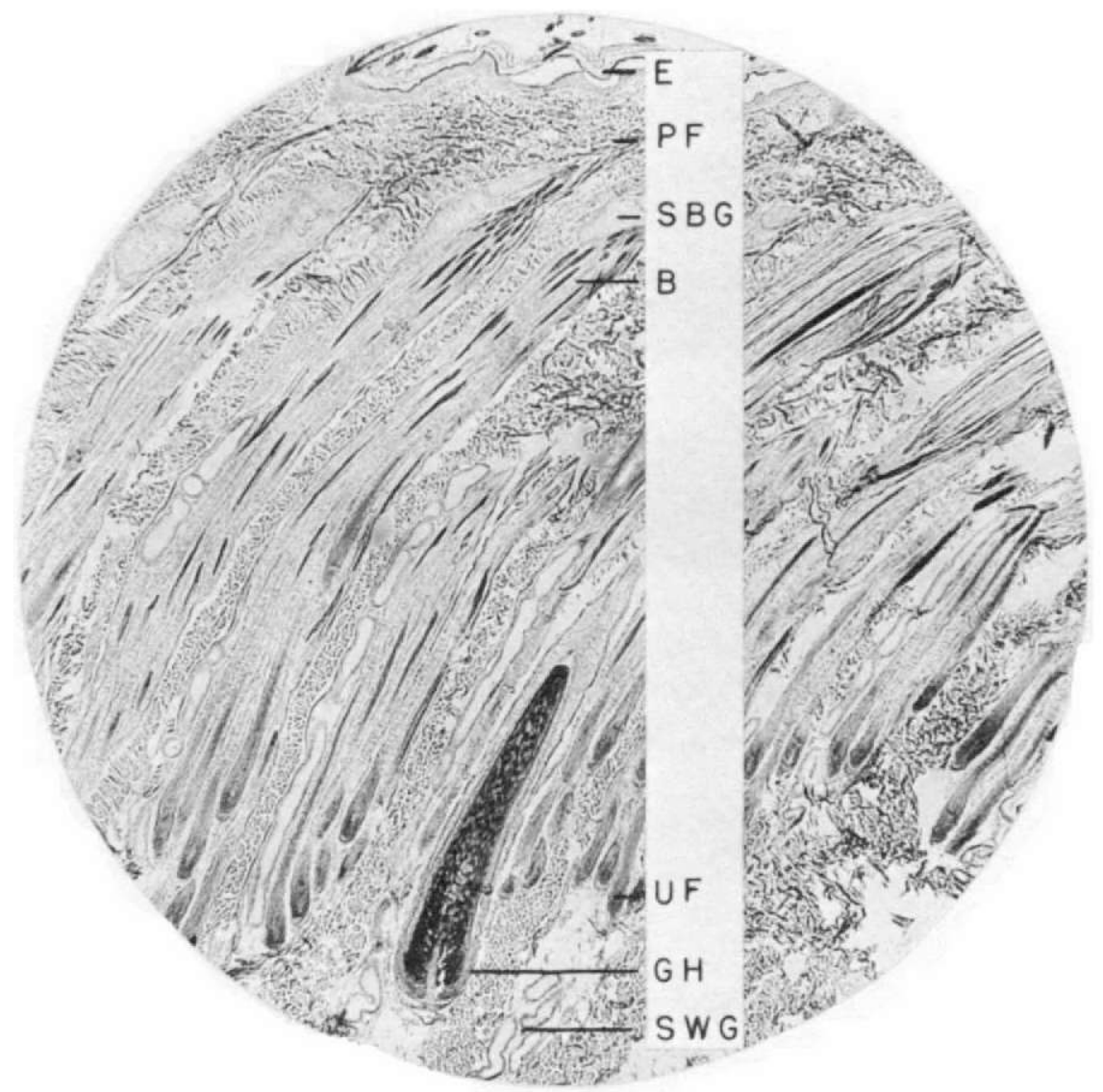

PLATe 9.-Median section through skin of back of 7-year-old male; 30 September; pelage not fully prime; pigment cells still active in bulbs of underfur follicles and guard-hair follicles; $\times 30$. B-bundle of underfur hairs; E-epidermis; GHguard-hair bulb; PF-pilosebaceous funnel; SBG-sebaceous gland; SWG-sweat gland ; UF-underfur-hair bulb. (4170) 


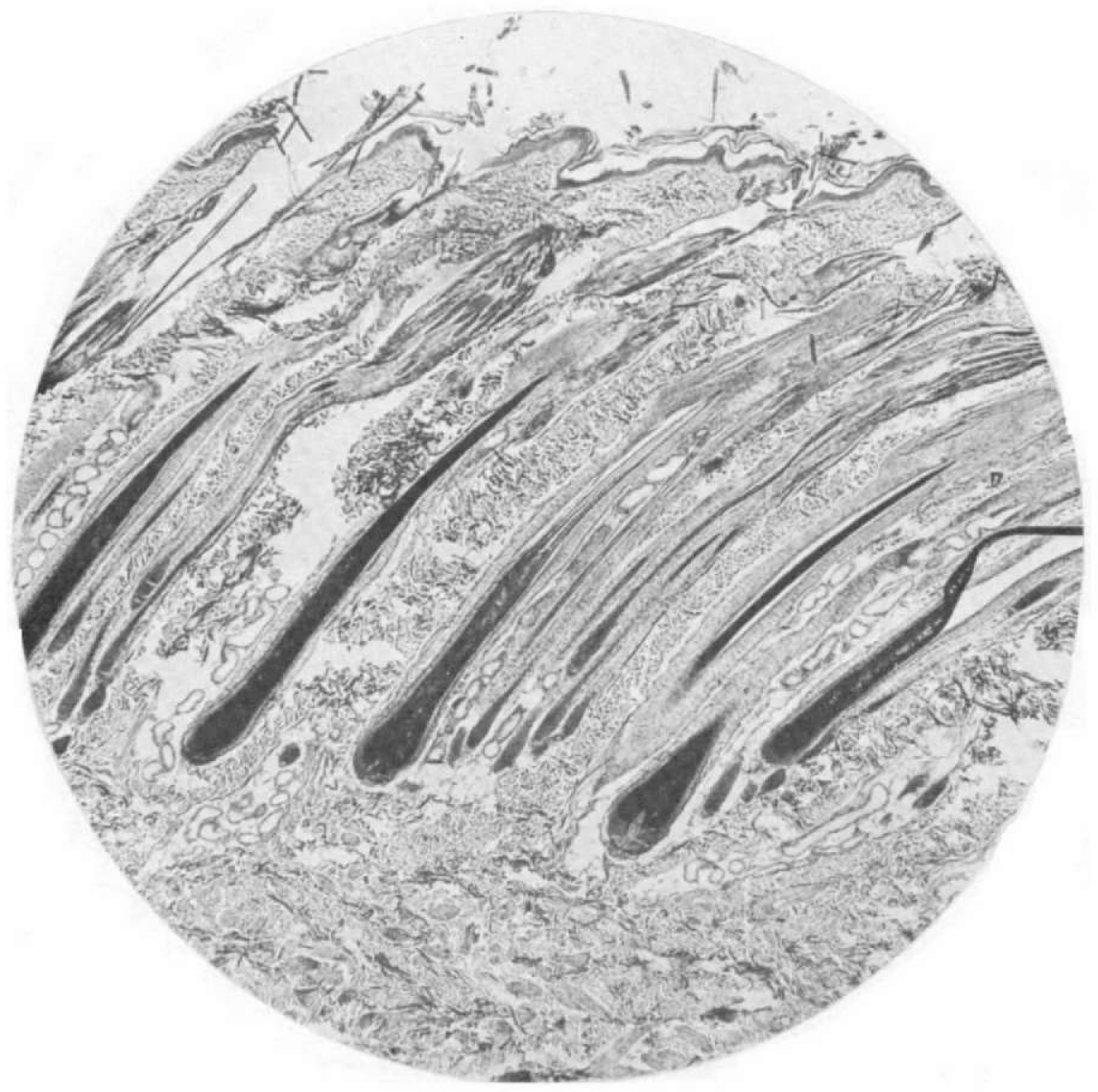

Prate 10.-Median section through skin of back of 7-year-old female; 30 September; $\times 30$.

(4171) 

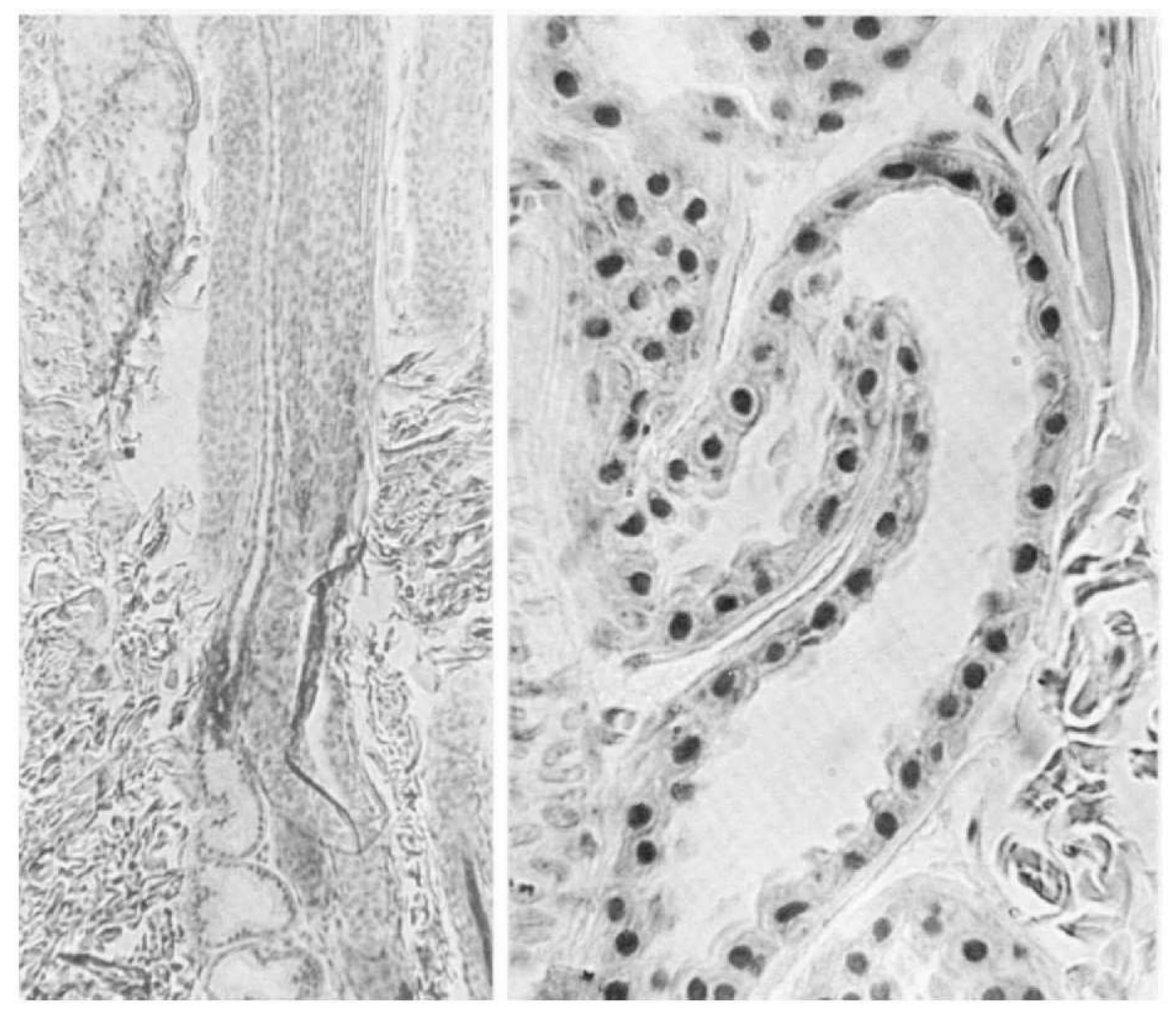

Plate 11,-( Left) Duct of sweat gland rising from secretory portion; median section of skin from back of 5-year-old female; 23 September; $\times 120$. (Right) Similar; secretory portion of sweat gland of 3-year-old female; 5 september $\times 400$.

(4176 and 4180) 


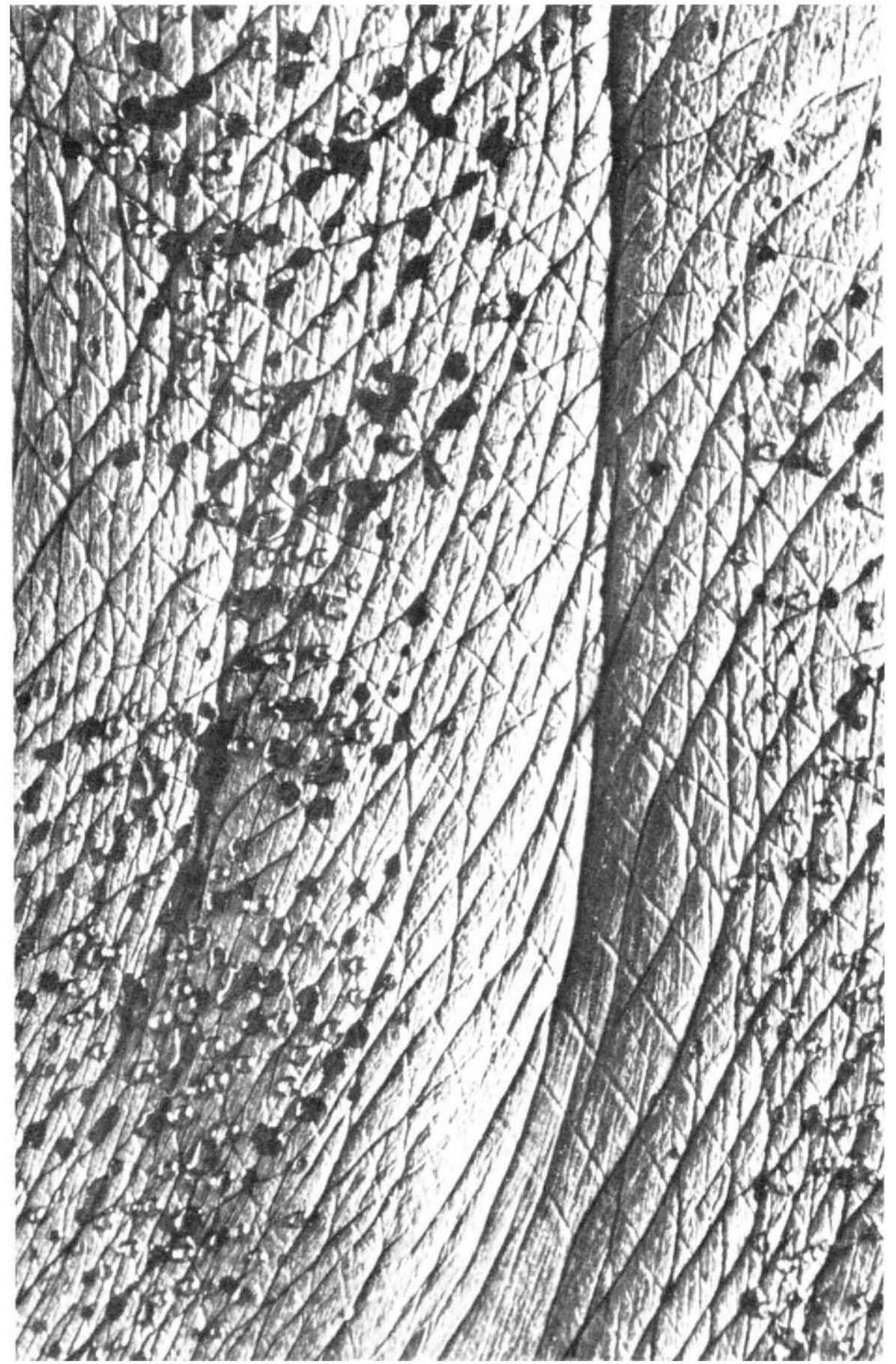

PIATE 12.-Sweit droplets appearing on palmar surface of fore flipper freshly severed from body of 3-year-old femaie seal; exposed to heat lamp; $\times 4 . \quad(4055)$ 


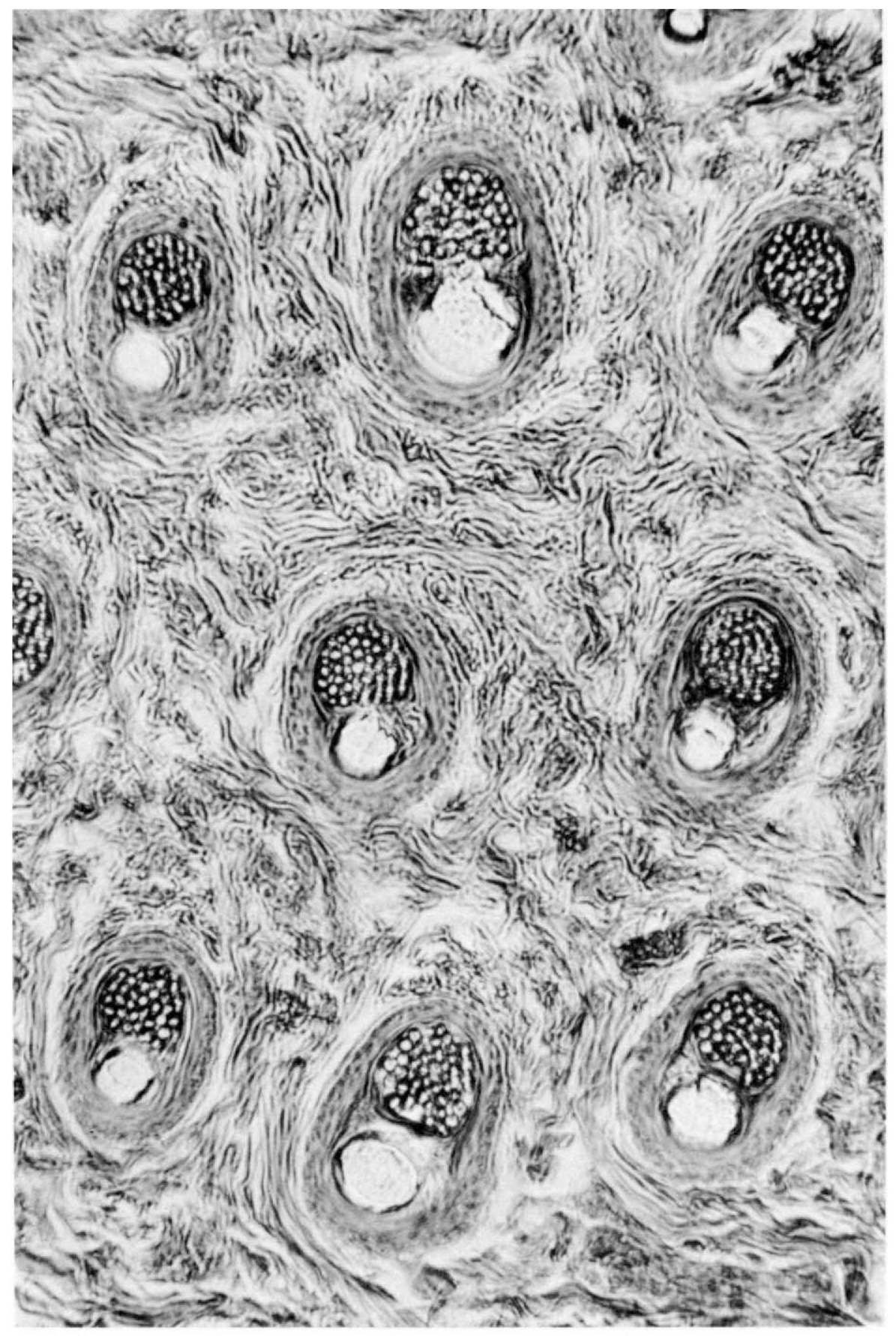

Plate 13.-Horizontal section, at depth of about $0.1 \mathrm{~mm}$, from back of neck of 3-year-old female; pelage fully prime; 7 February; posterior end at top; $\times 200$. Note 8 entire follicular bundles, each with a single, large, round, translucent section of guard-hair root and 35 to 40 underfur roots. 


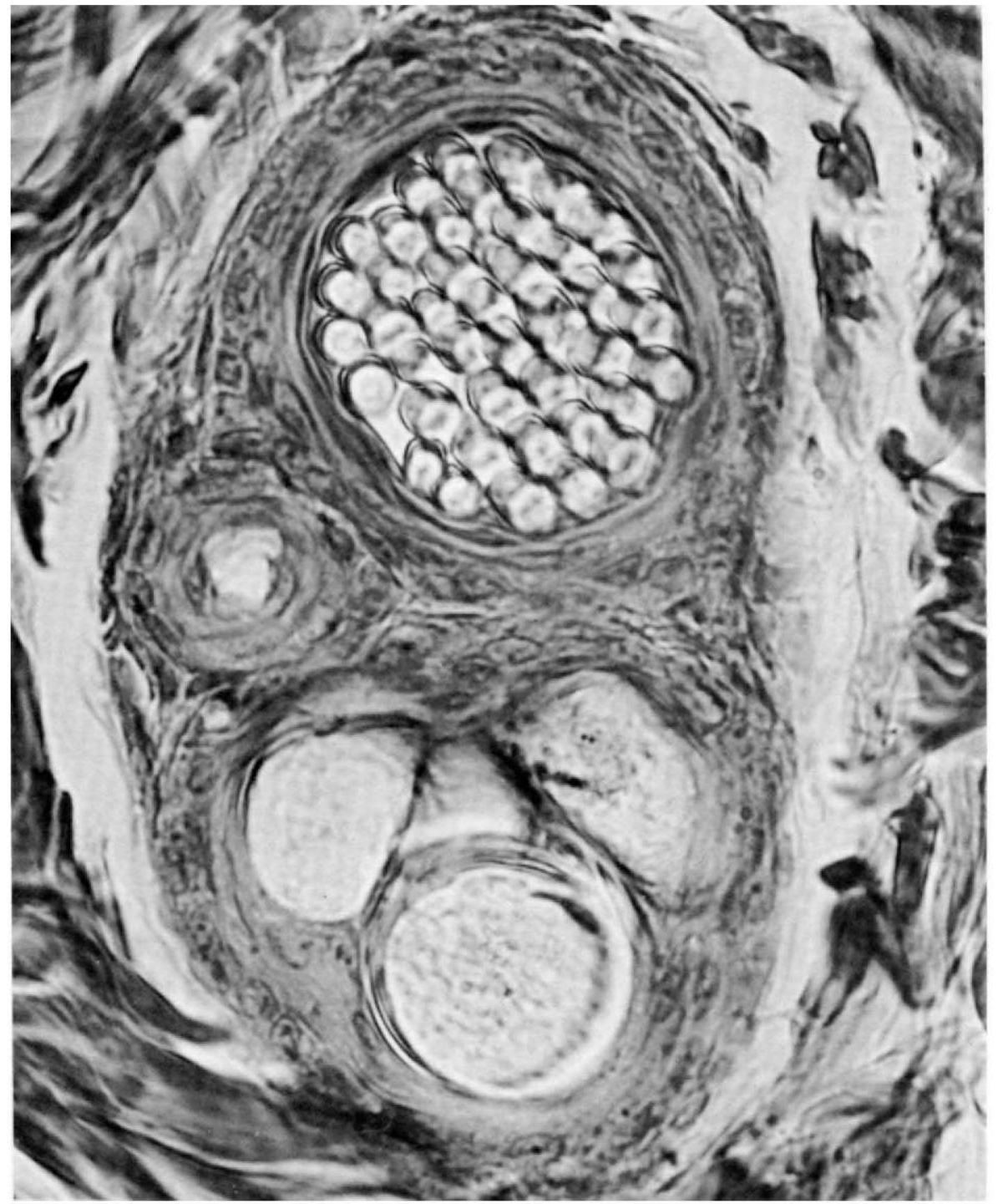

Puate 14,-A single follicular bundle; $\times 800$. Note (above) bundle of 40 underfur fibers, (left) sweat duct, and (below) guard hair flanked by 2 sebaceous ducts.

(4213) 


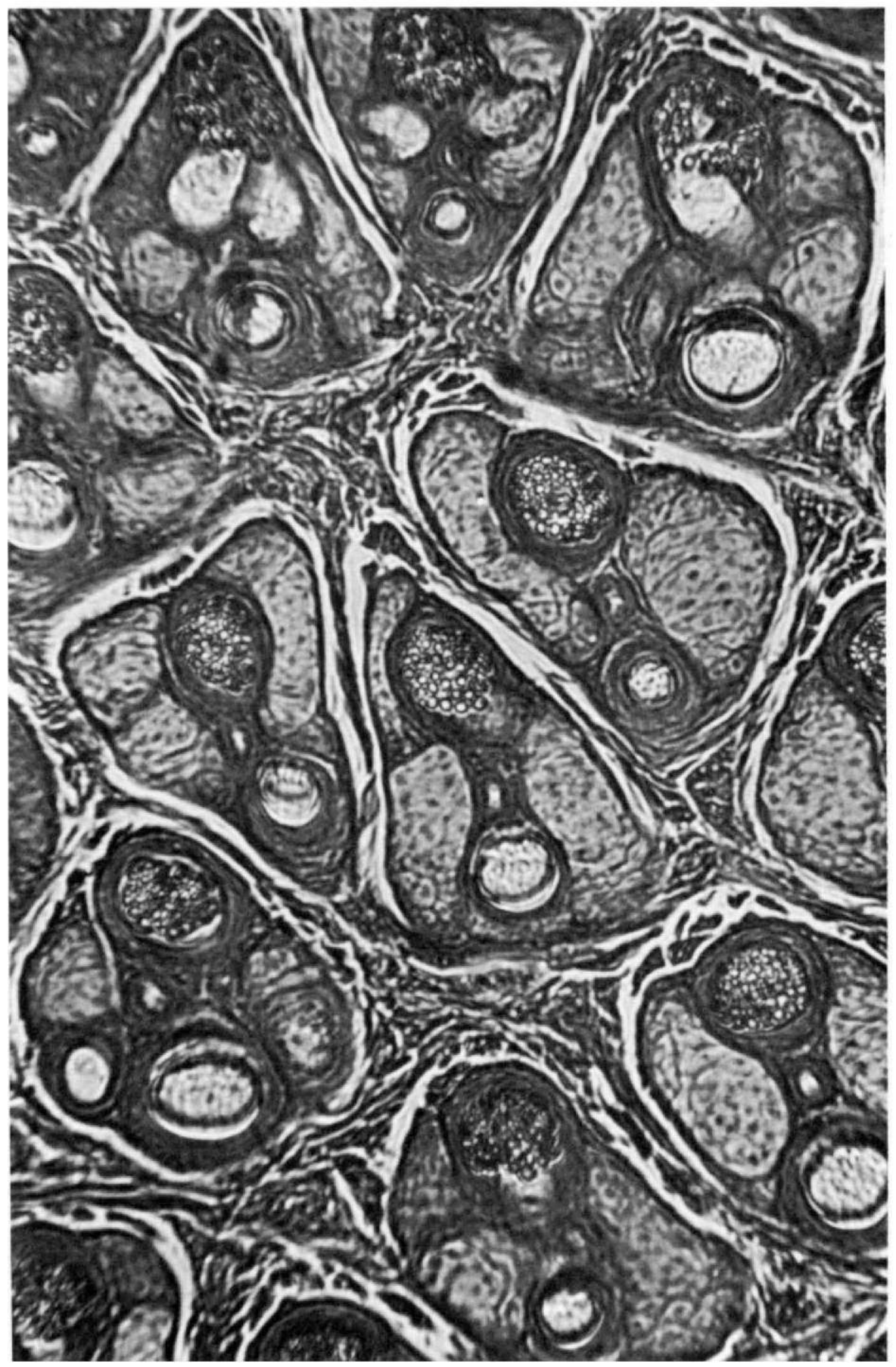

Plate 15. - (See pl. 13.) Section at depth of about $0.4 \mathrm{~mm}$., where sebaceous glands are largest in cross section; $\times 200$. Note sweat duct between guard hair and fur bundle. 


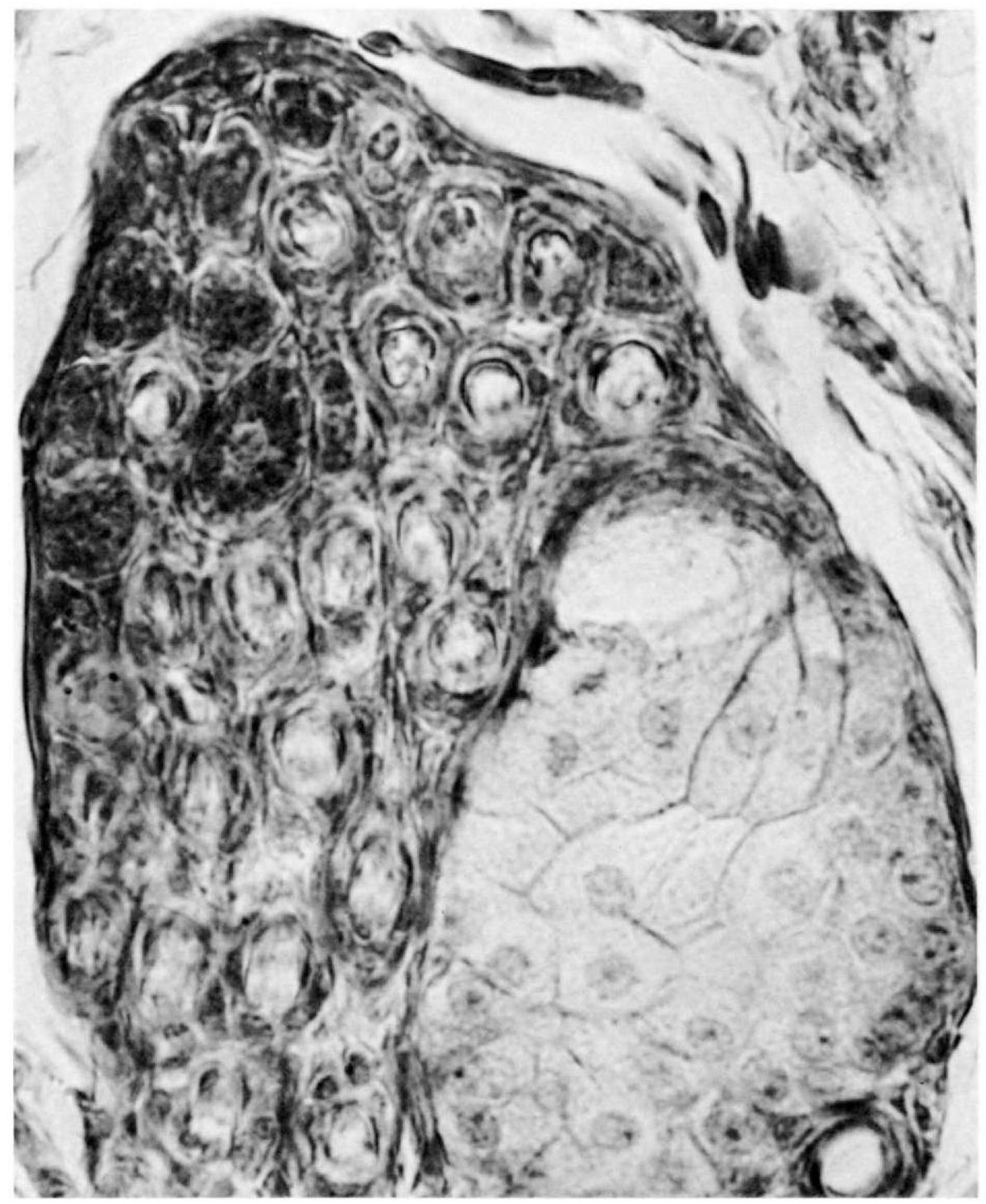

Plate 16.--(See pl. 13.) Section at depth of about $1.0 \mathrm{~mm}$., near base of underfur roots; $\times 640$. Note follicles of underfur fibers at various levels; some being more superficial, appearing as dark bulb-sections. At lower right, the sweat duct rises through the base of a large sebaceous gland.

(4215) 


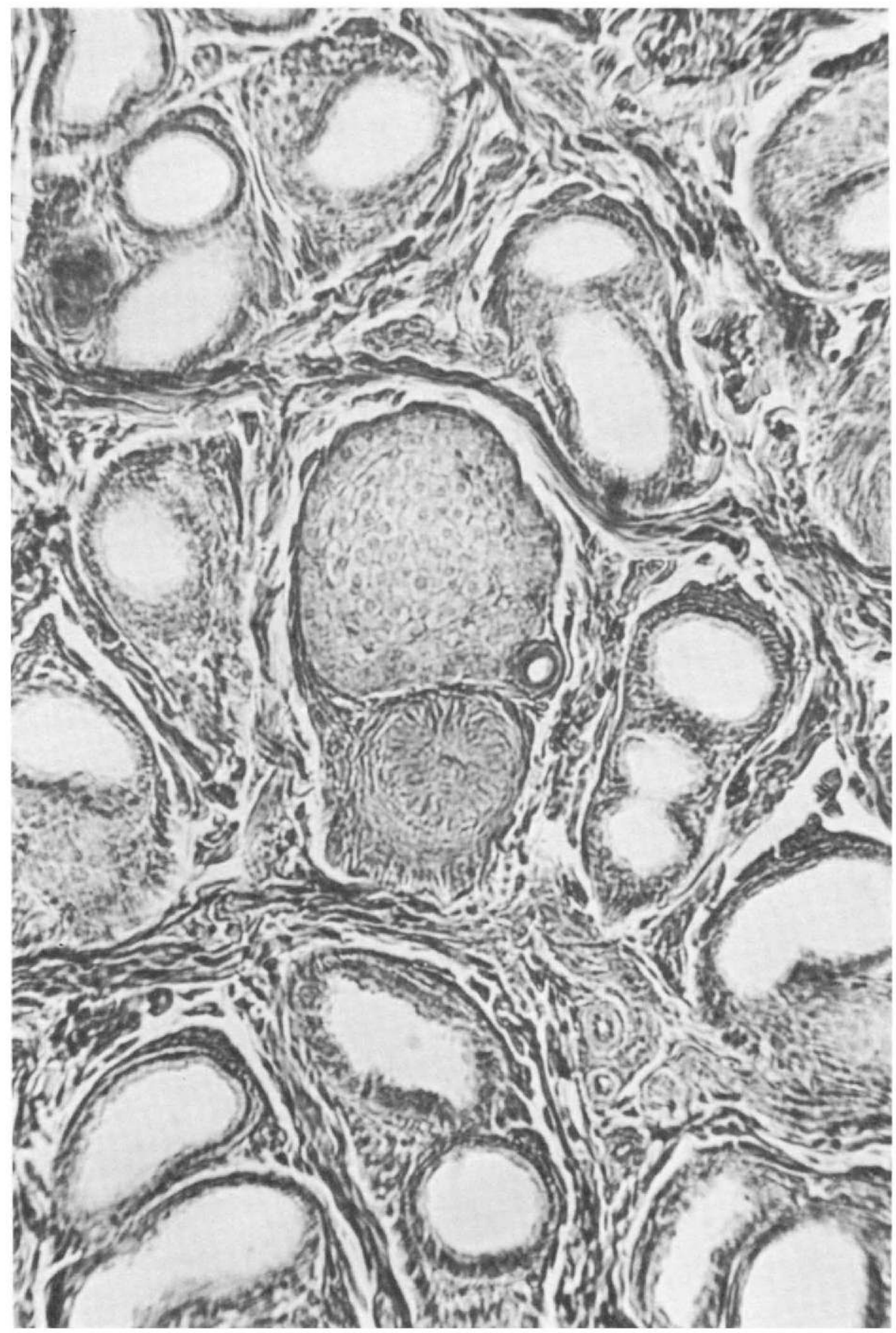

Plate 17.-(See pl. 13.) Section at depth of about $1.2 \mathrm{~mm}$., showing lumens of sweat glands; $\times 200$. Note (center) the dome of a gland, with its duct, beside a guard-hair follicle. (On another section cut nearer the surface, a bundle of underfur fibers is situated vertically above this dome.)

(4216) 

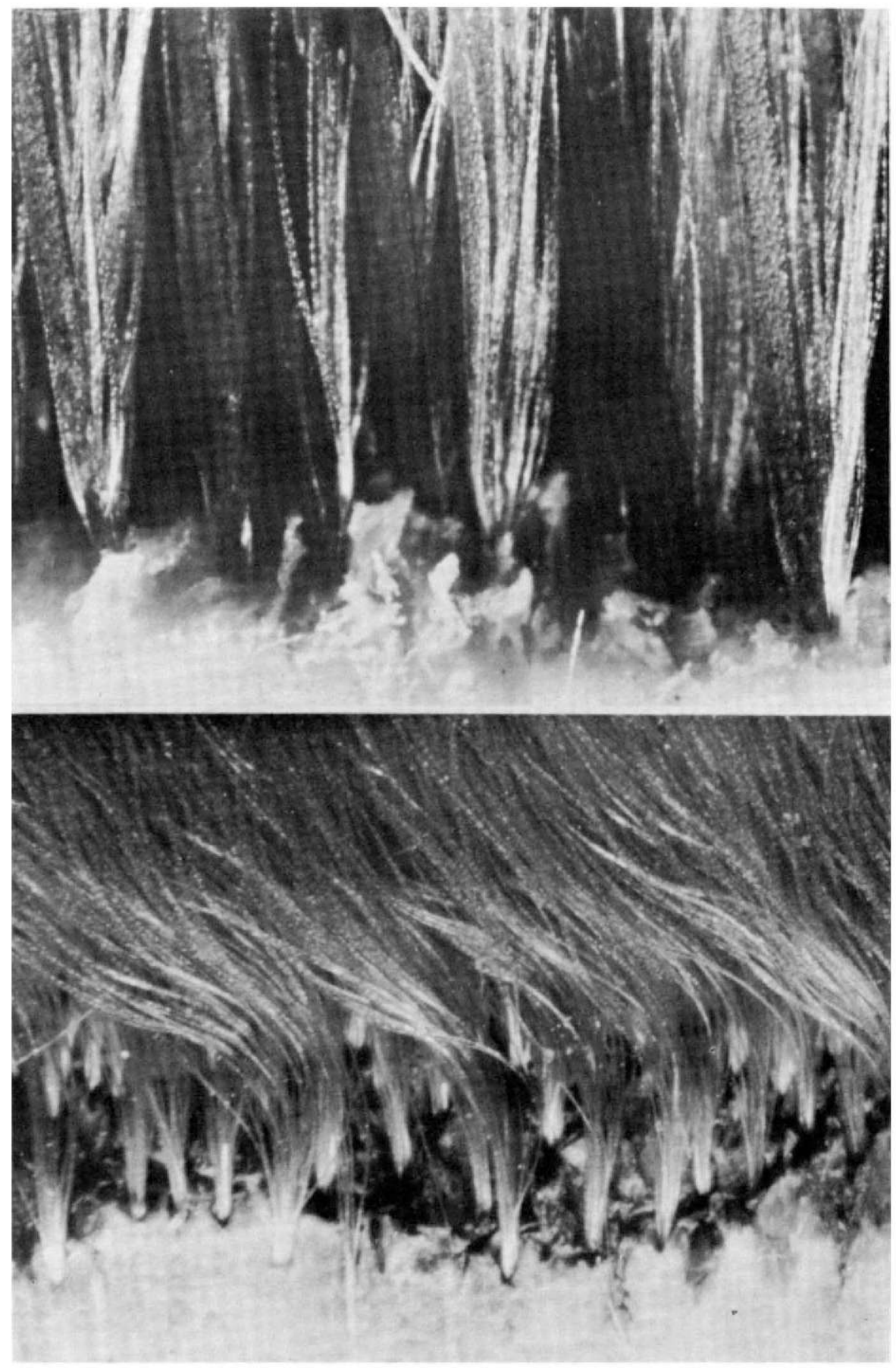

Plate 18.-Bundles of fibers rising from surface of skin of subadult male; anterodorsal view. (Above) Parchment-cured skin. (Below) Plucked, chamois-tanned, black-dyed skin.

(3986 and 3939) 

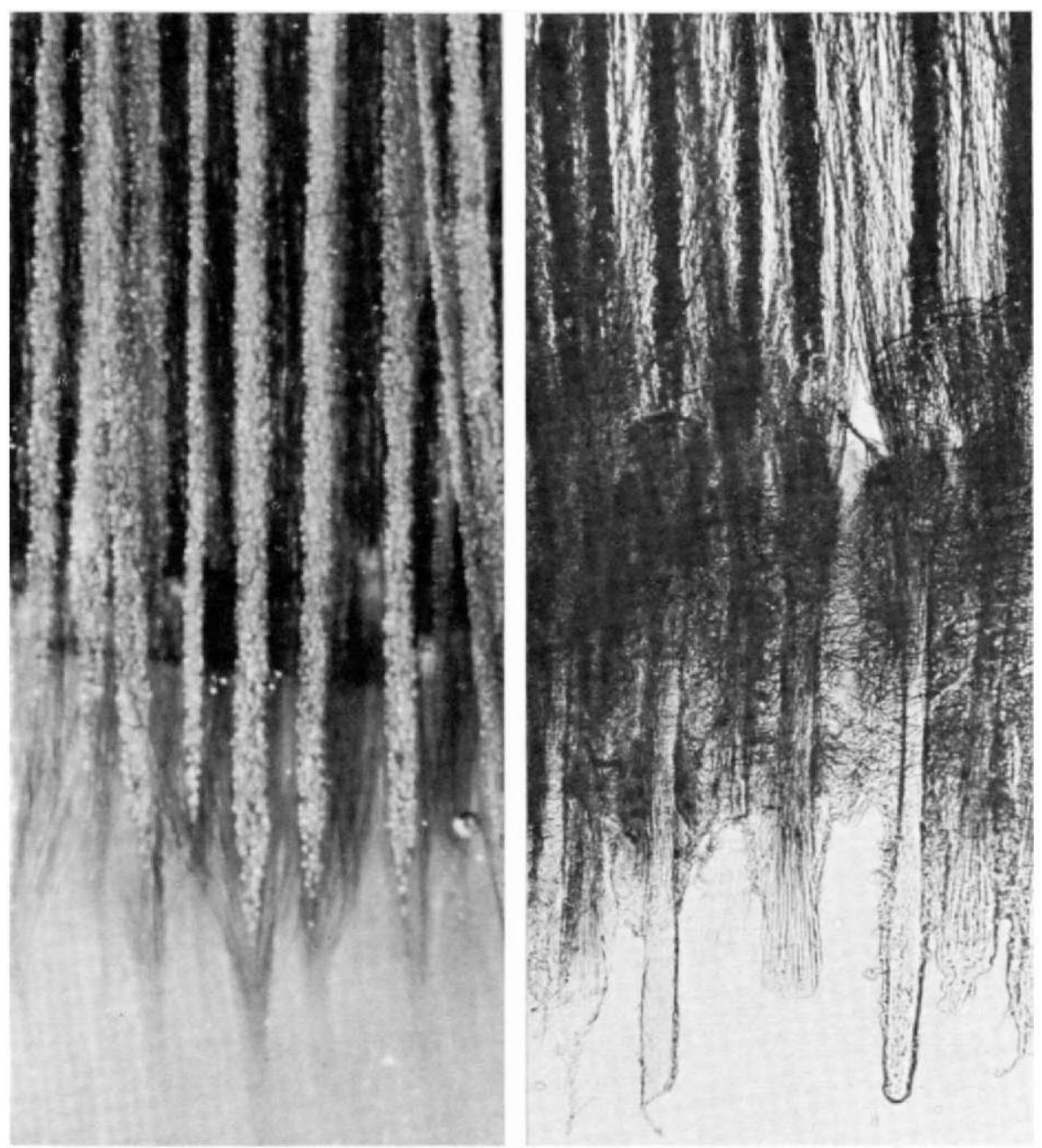

Plate 19.-Bundles of flbers rising from surface of skin of subadult male; anterodorsal view ; $\times 40$. (Left) Hyrax mount; each prominent, white-dotted column is the medulla of a guard hair. A tuft of underfur fibers, nonmedullated, rises from the pilosebaceous orifice behind the guard hair. (Right) Polyvinyl-acetate mount, showing portion of root as well as shaft; medulla here appearing black rather than white.

(3929 and 4114) 


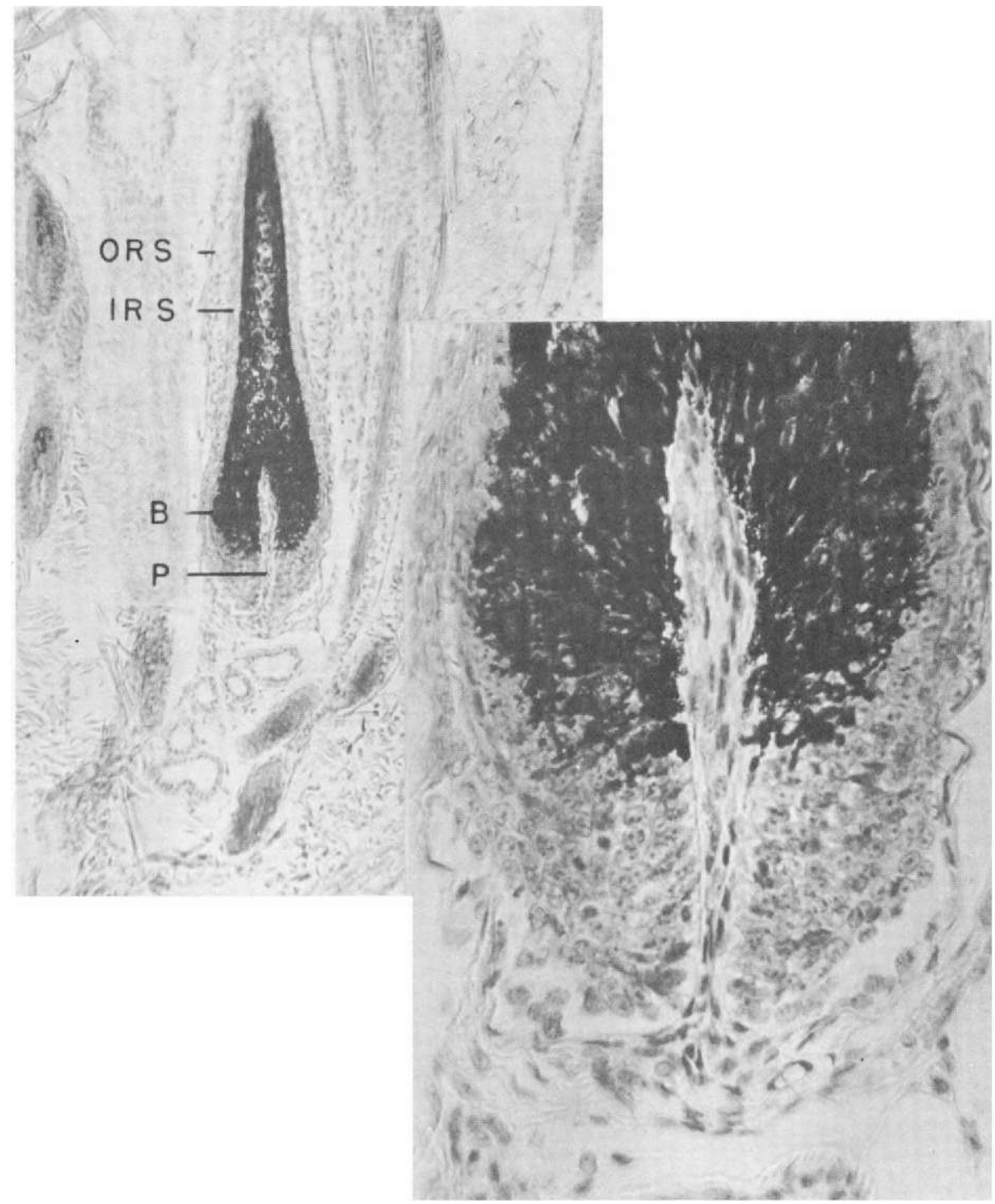

Prate 20.-Root of guard-hair follicle in median section of skin from back of 4-year-old male; 2 September; $\times 80$ (above) and $\times 400$ (below). B-bulb; IRS-inner root sheat; ORS-outer root sheat; P-papilla. (4182 and 4183) 


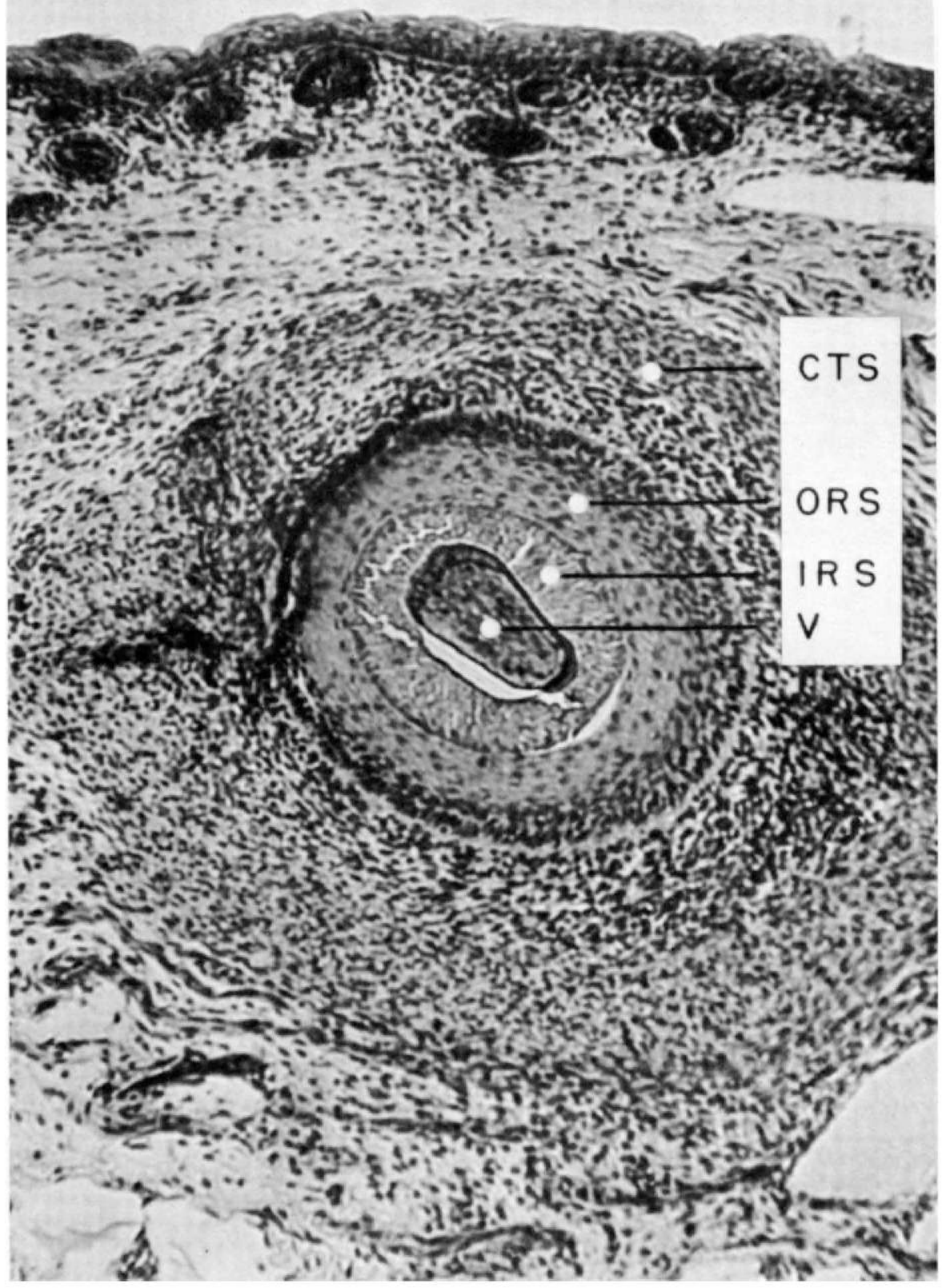

Plate 21.-Vibrissa of $144 \mathrm{~g}$. fetus; 25 January; cross section of upper portion of follicle; $\times 200$. Primordia of nonspecialized body hairs appear at top of photo. CTS-connective tissue sheath (much thicker around vibrissa than around guard hair) ; IRS-inner root sheat; ORS--outer root sheath; V-vibrissa, mainly pigmented cortex with thin, dark cuticle and suggestion of central medulla. (4163) 


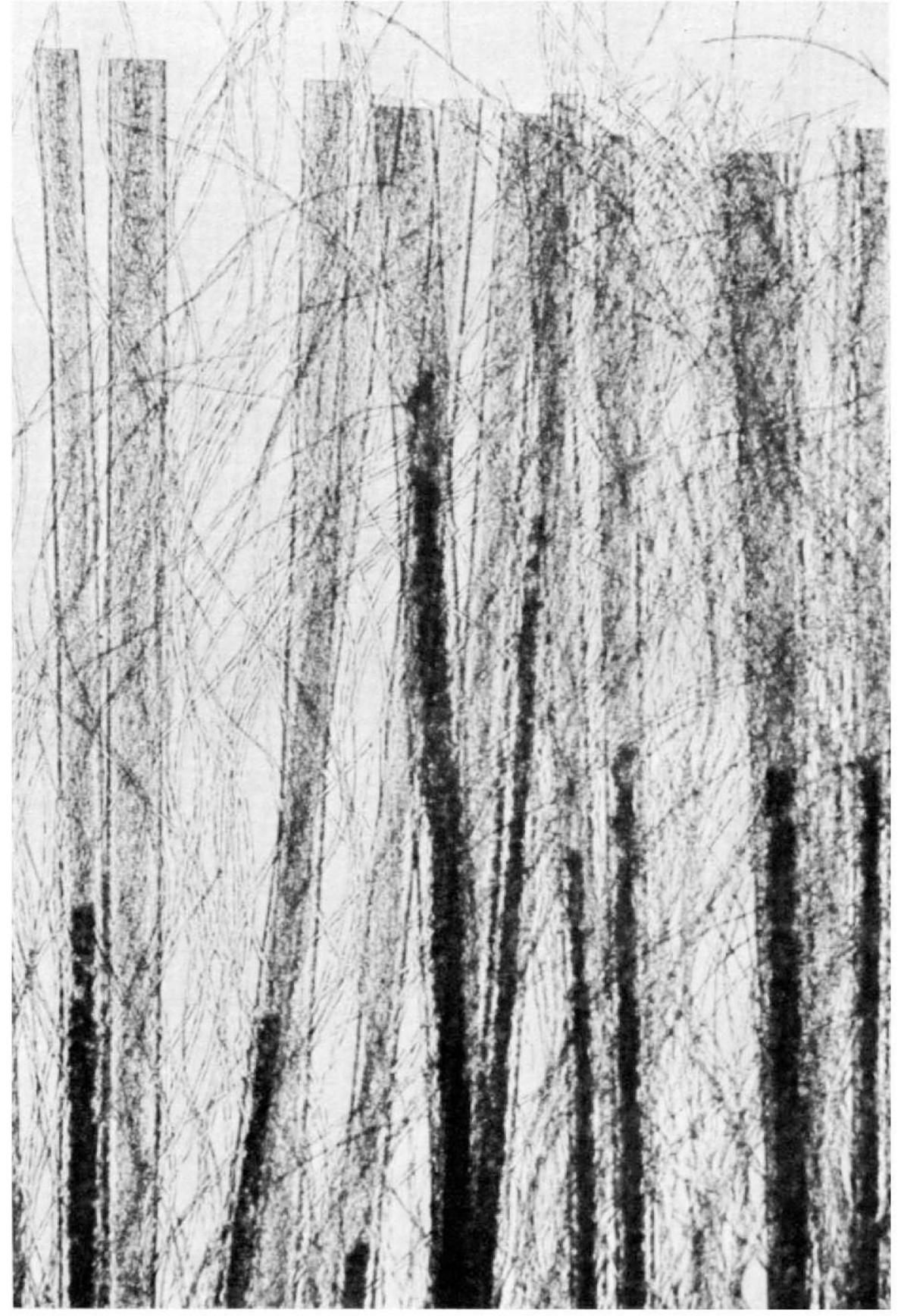

Plate 22,-Stumps of underfur fibers and guard hairs from parchment-cured sealskin; in tri-n-butyl phosphate; fibers cut at approximately halfway point; anterodorsal view showing flat side of each guard hair; mountant has partly invaded medulla and has pushed original gas upward through cut tips of guard hair; $\times 50$.

(4118) 


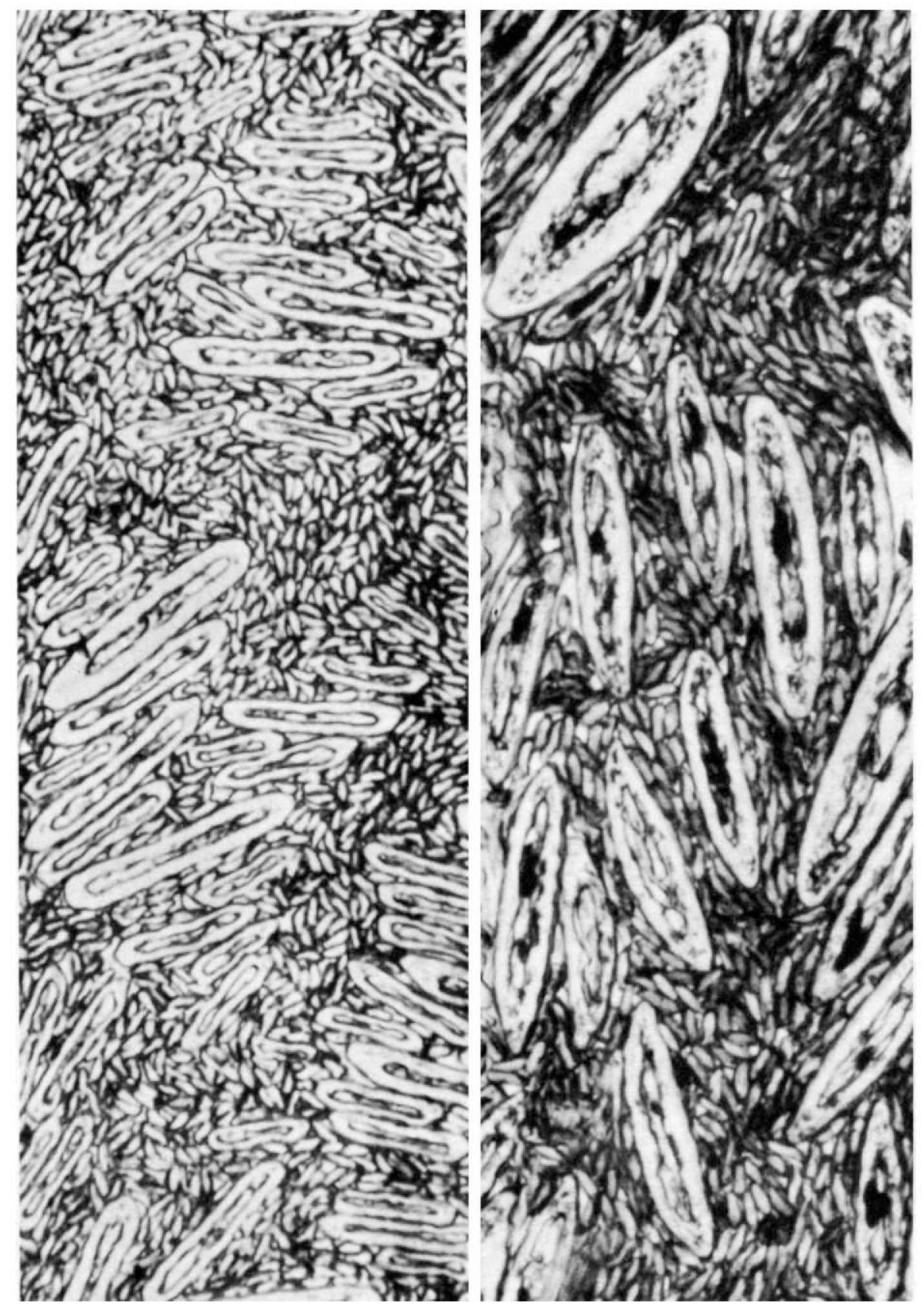

Plate 23.-Cross sections (by Hardy device) of adult-type pelage; $\times 300$. (Left) Prime silver pup; 13 October; tanned skin. Smallest bodies are underfur fibers; largest are guard hairs of various sizes. (Right) Subadult male; 12 July; parchment-cured skin. Note that guard hairs are larger and darker here.

(4153 and 4112) 

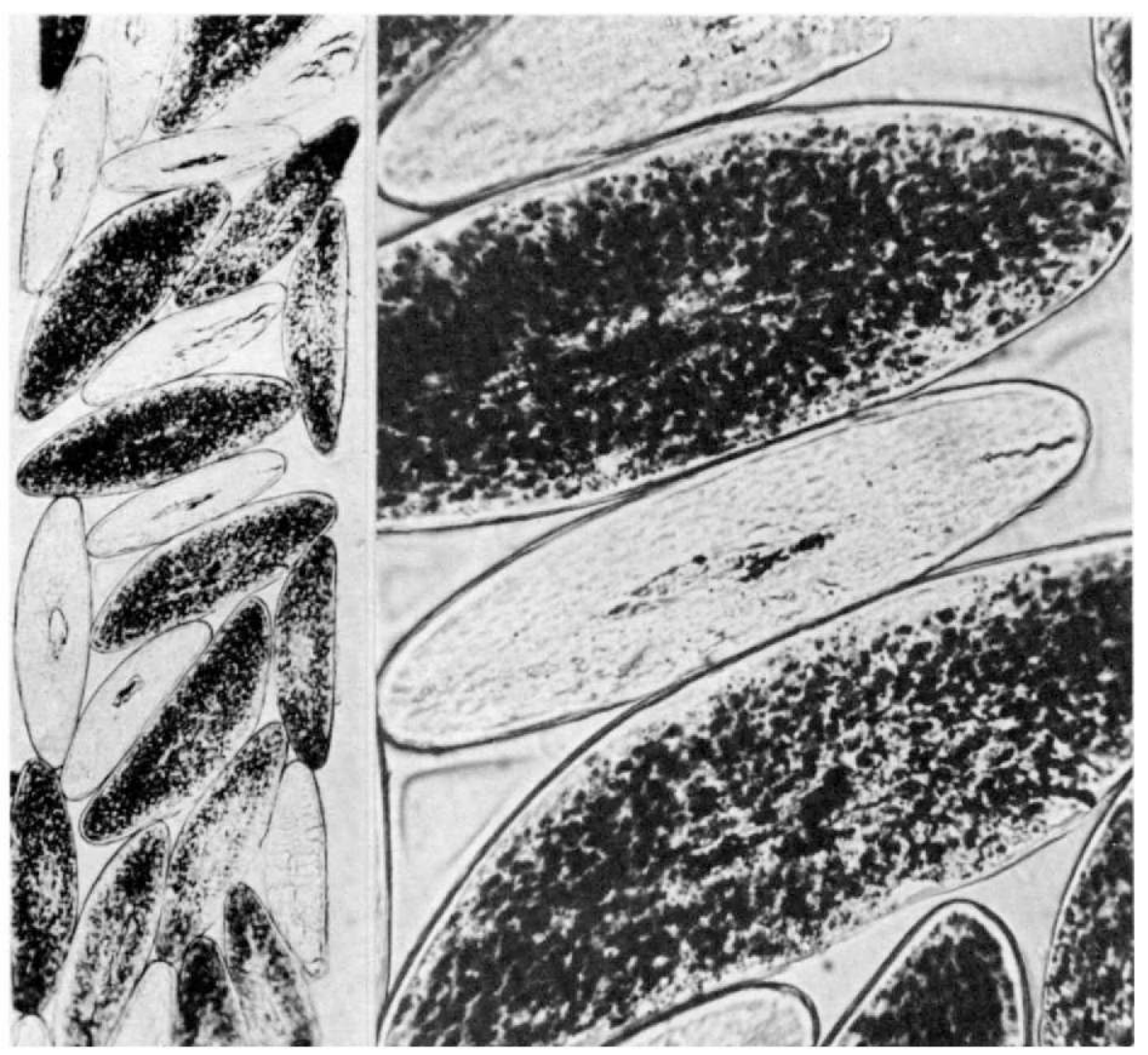

Plate 24.-Cross section of coarse mane hairs; some white and some dark brown; cut about $1 \mathrm{~cm}$. from surface of skin; 10-year-old male; (left) $\times 120$; (right) $\times 800$. 


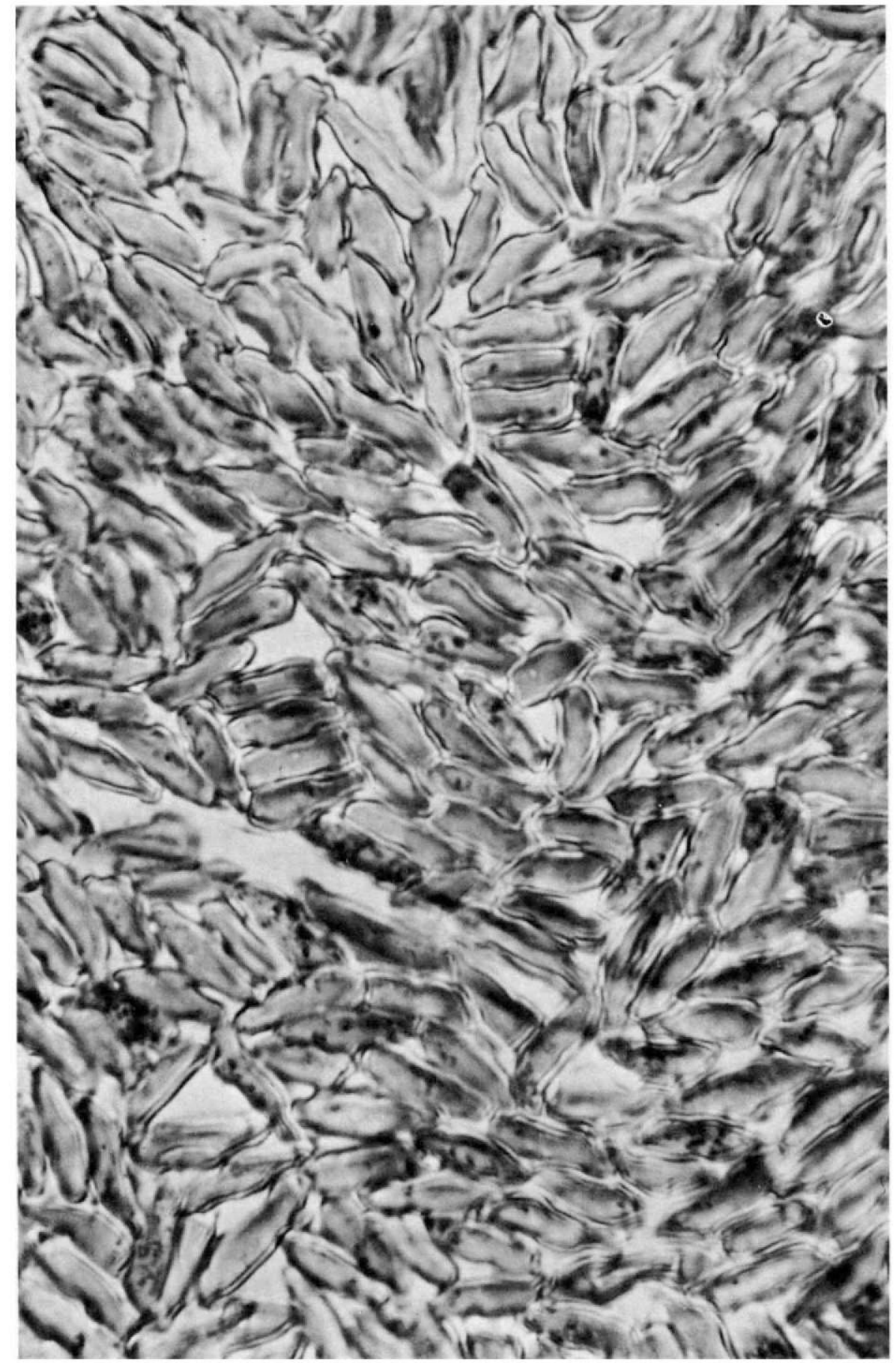

Plate 25.-Cross section of underfur fibers of finished, brown-dyed, subadult male sealskin; $\times 1000$.

(4110 C) 


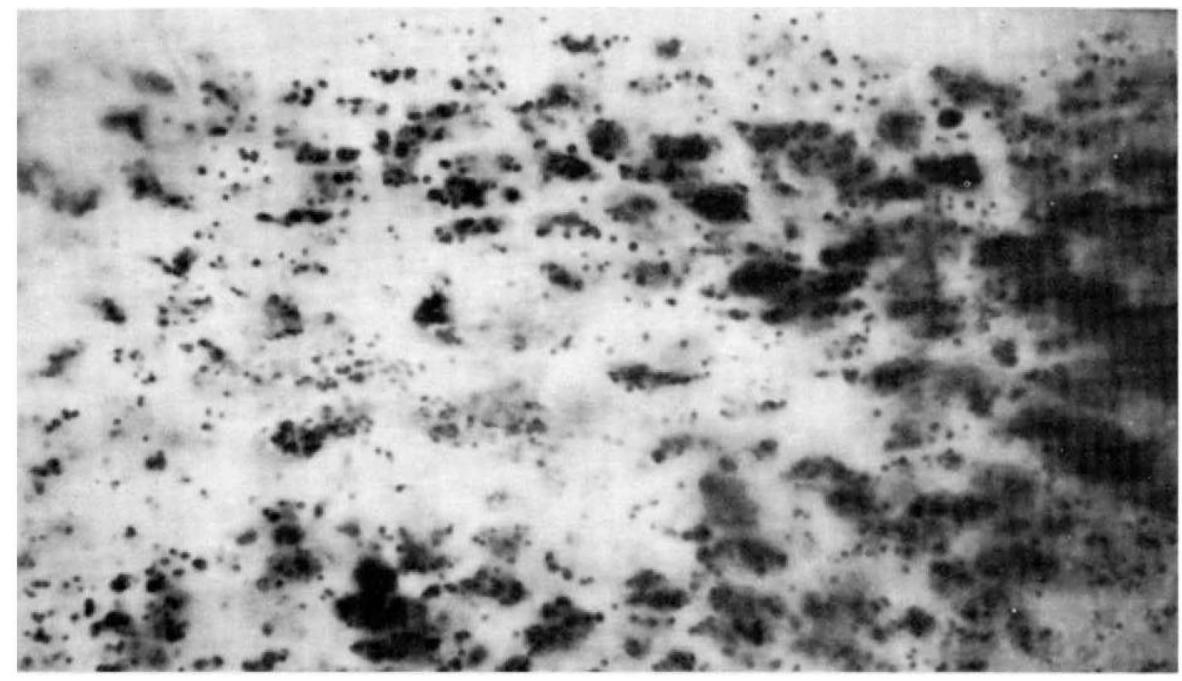

Plate 26-A.-Pigment granules in blade of large guard hair from mane of 10-year-old male; field includes about one-third of cross section; medulla not open at this level; $\times 1000$.

(4160)

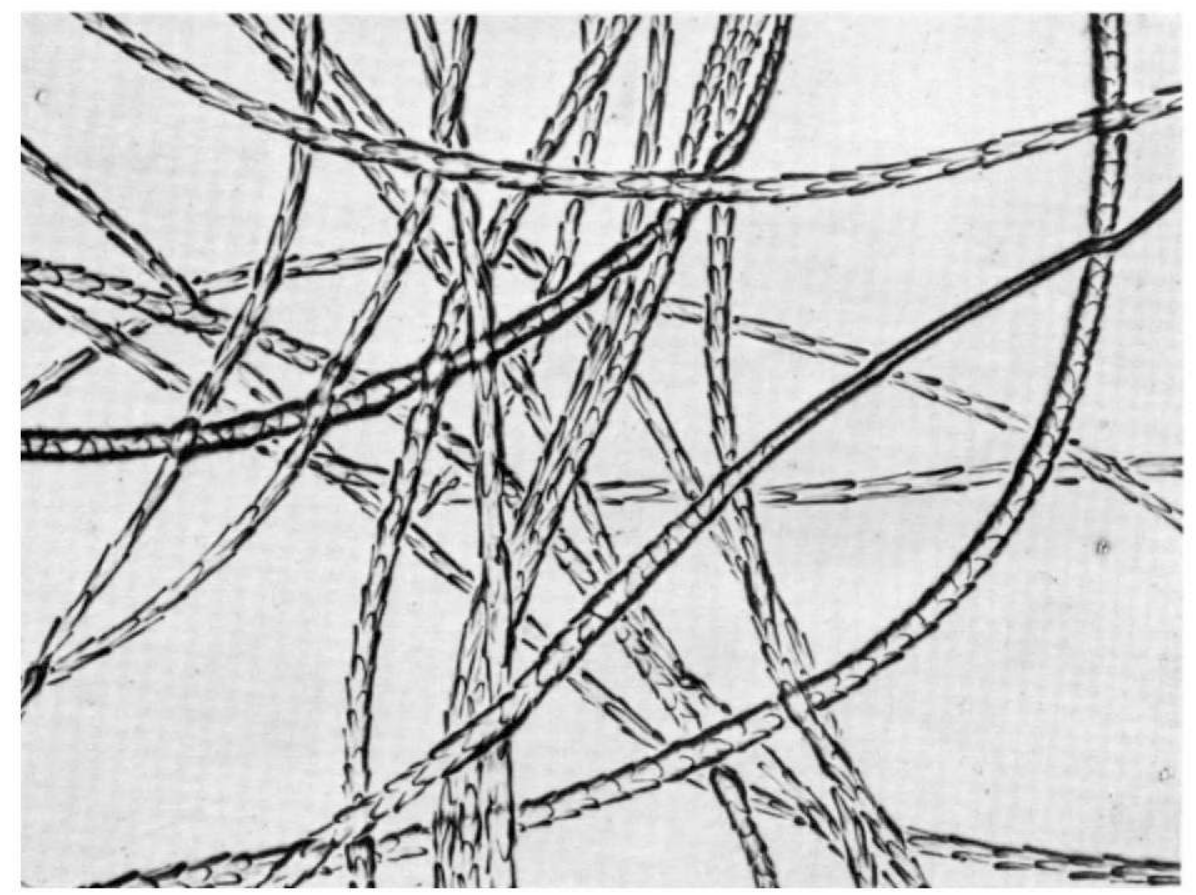

PLATE 26-B.-Underfur fibers from back of subadult male; parchment-cured skin; thermoplastic cast; $\times 100$. Note smooth attenuated root of one fiber.

$(4089 \mathrm{~A})$ 

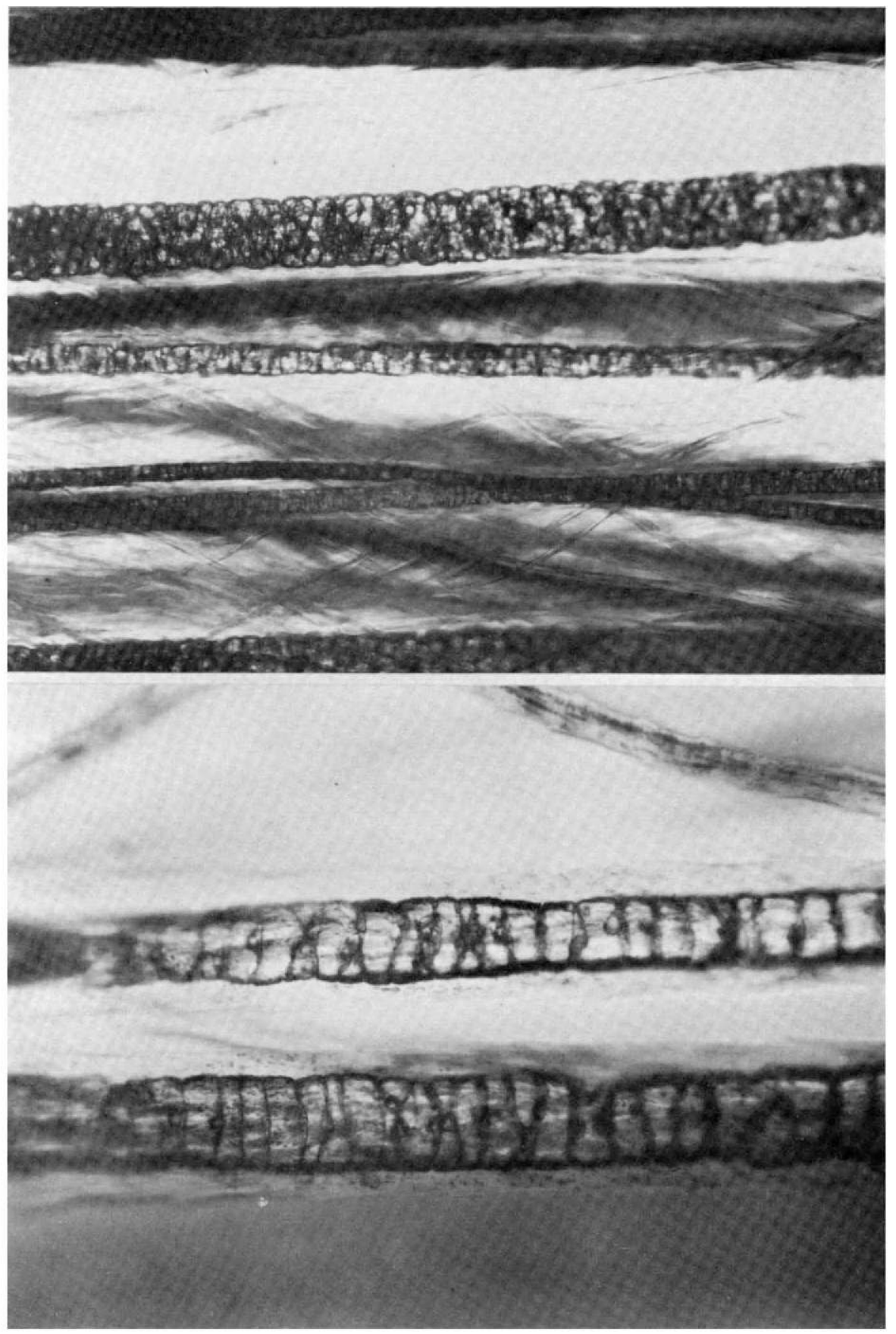

P'lATE 27.-Guard hairs against background of fine underfur fibers; first adult-type pelage; silver pup; 13 October. (Only the medulla or pith of the hair stands out in this mountant.) (Above) Hairs of various sizes; $\times 100$. (Below) Portions of two medium-size hairs; $\times 500$. (4102 A and $4102 \mathrm{~B}$ ) 

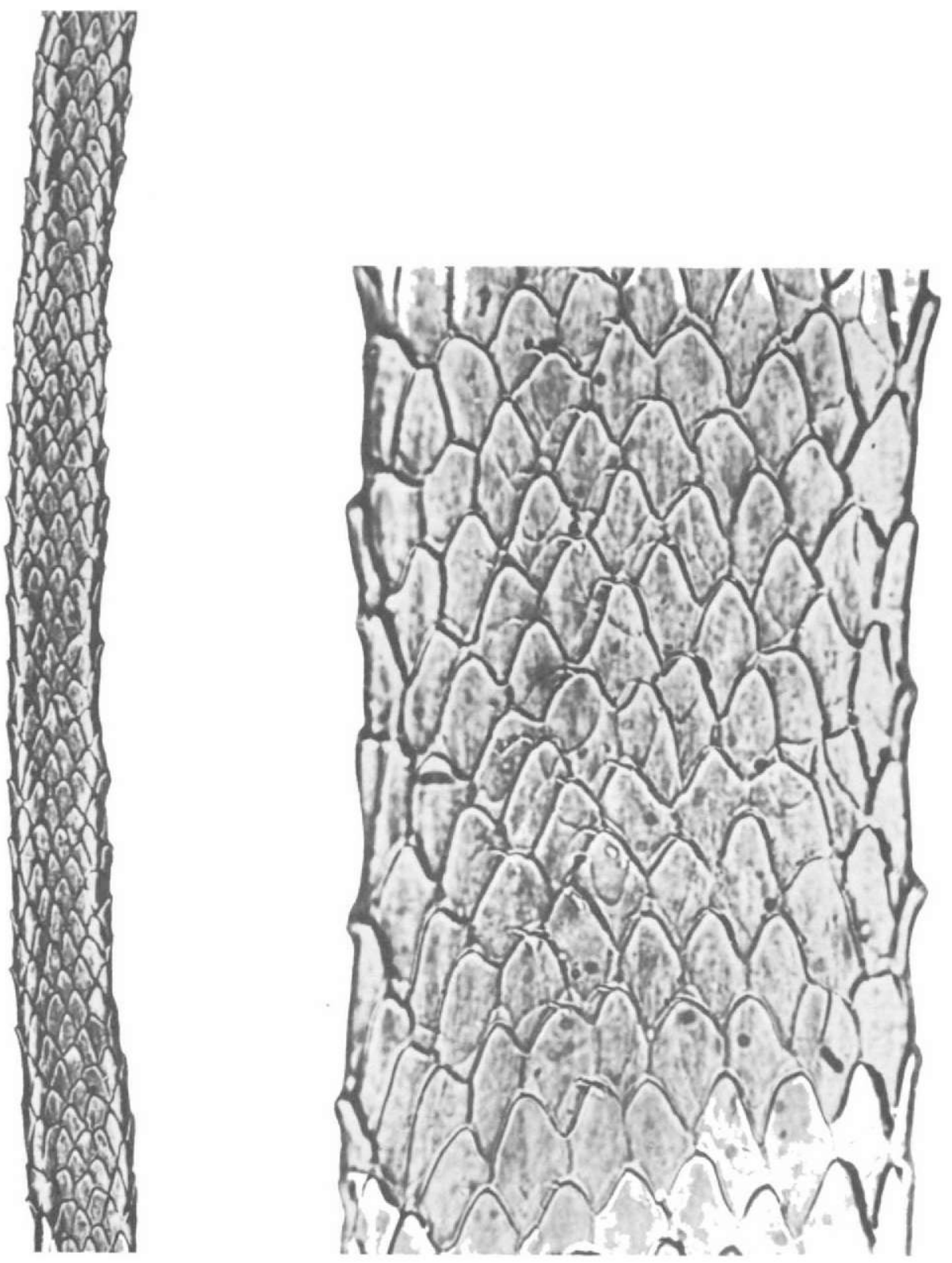

Plate 28. Cuticilar-scale pattern on basal region of shaft of guard hair ; parchmentcured skin; thermopiastic casts; $\times 100$ and $\times 500$. (4092 $\mathrm{O}$ and 4094 ) 


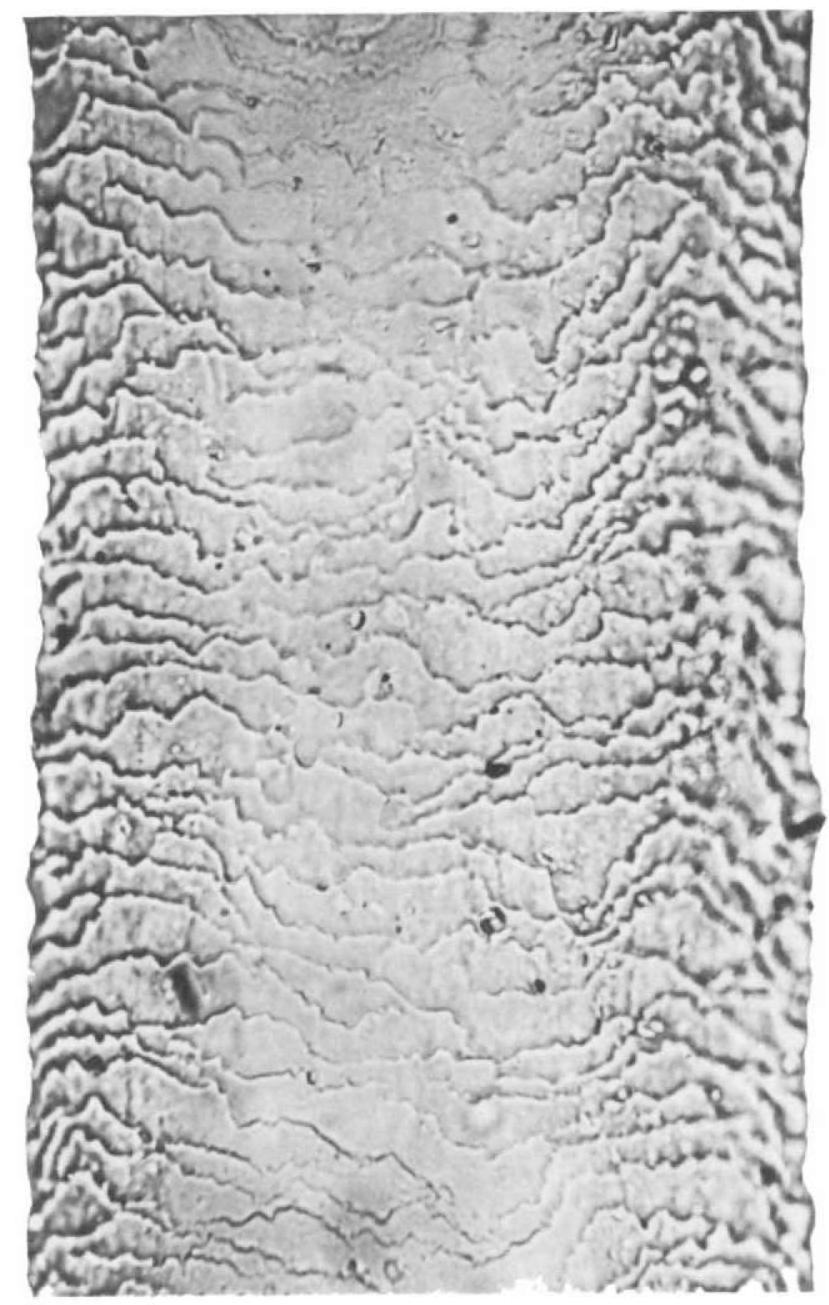

PLate 29. - Cuticular-scale pattern on blade of shaft of guard hair; parchment-eured skin ; thermoplastic cast; $\times 500$.

(4091 B) 

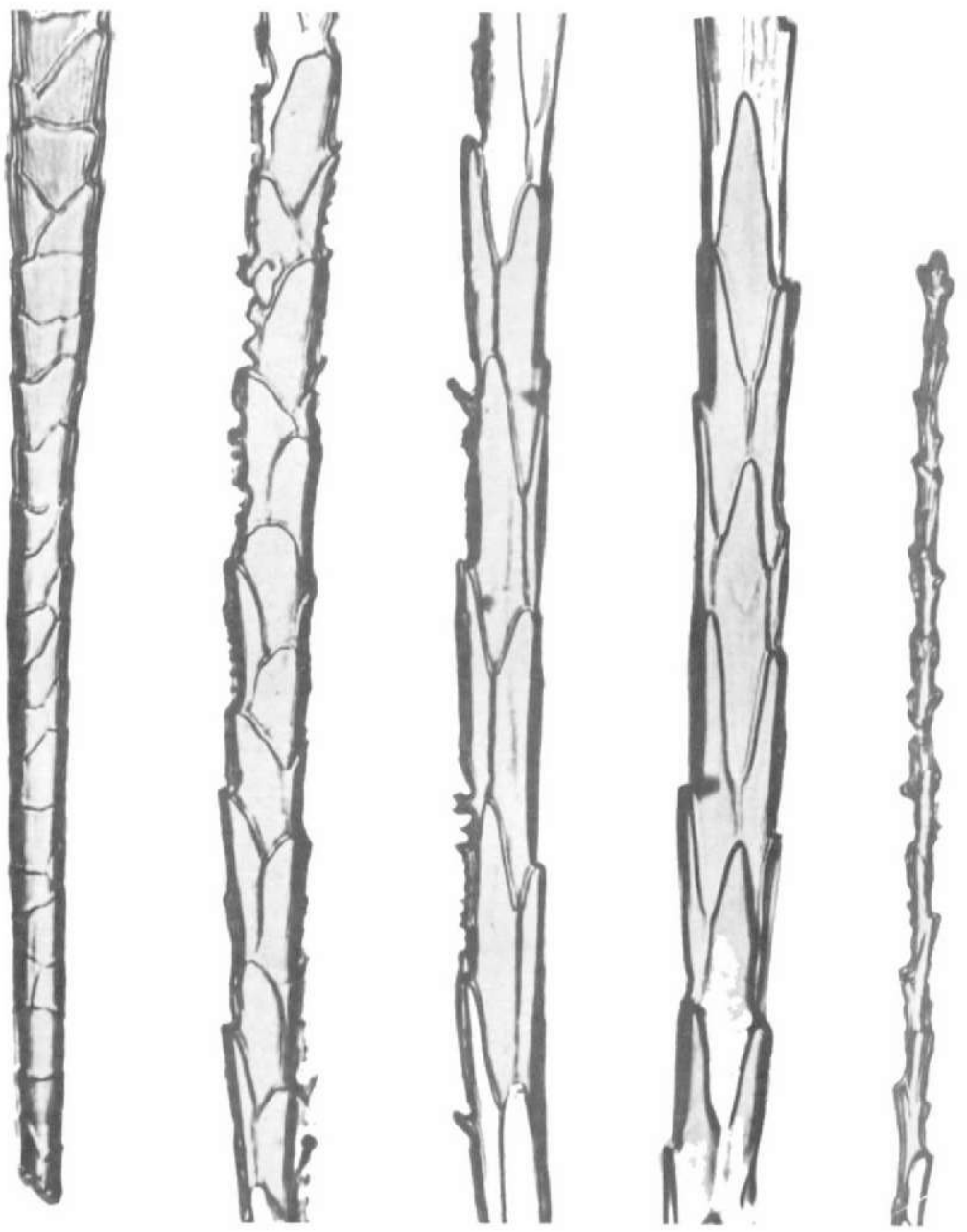

Plate 30.-Cuticular-scale patterns on underfur fibers from pelt of subadult male; parchment-cured; gelatin casts; $\times 500$. (Left to right) basal region, middle region ( 3 fibers), and tip.

(4088 A, B, C, D, F) 


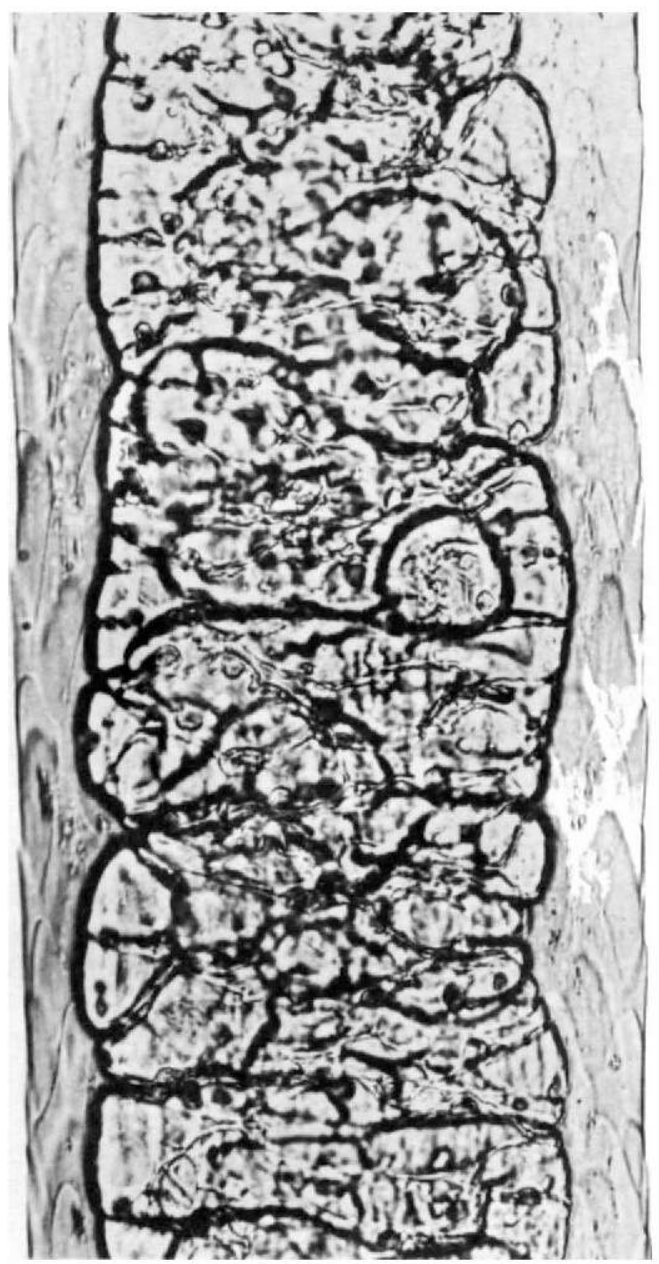

Plate 31,-Medulla of guard hair of albino in first adult-type pelage; 2 December; basal region of shaft in benzol; $\times 500$. Gas-filled chambers of the medulla reflect light and cause the pelage to appear white. (4185) 


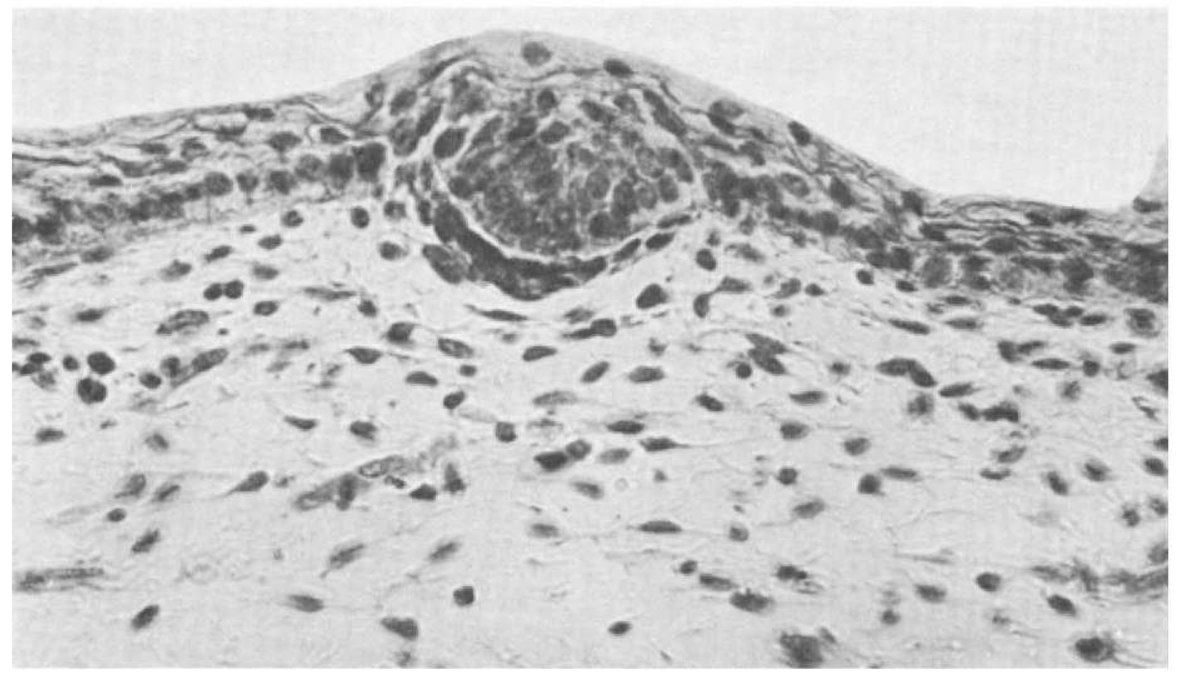

PLATE 32-A.-Primordium of hair follicle developing as thickening of epidermis in skin of back of $23.7 \mathrm{~g}$. fetus; $\times 500$.

(4158)

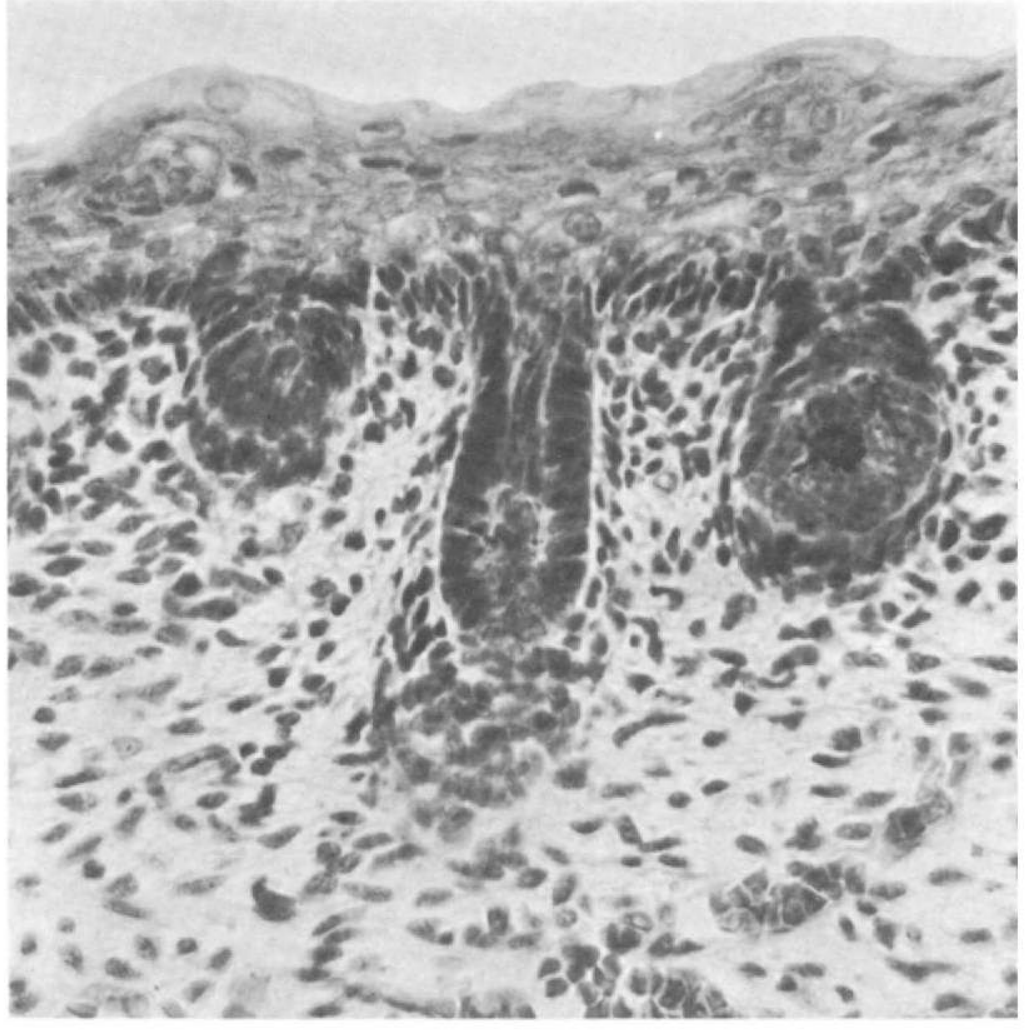

I'AATE 32-B.-Three early follicles pushing downward into dermis of $161 \mathrm{~g}$. fetus; $\times 500$.

(4162) 


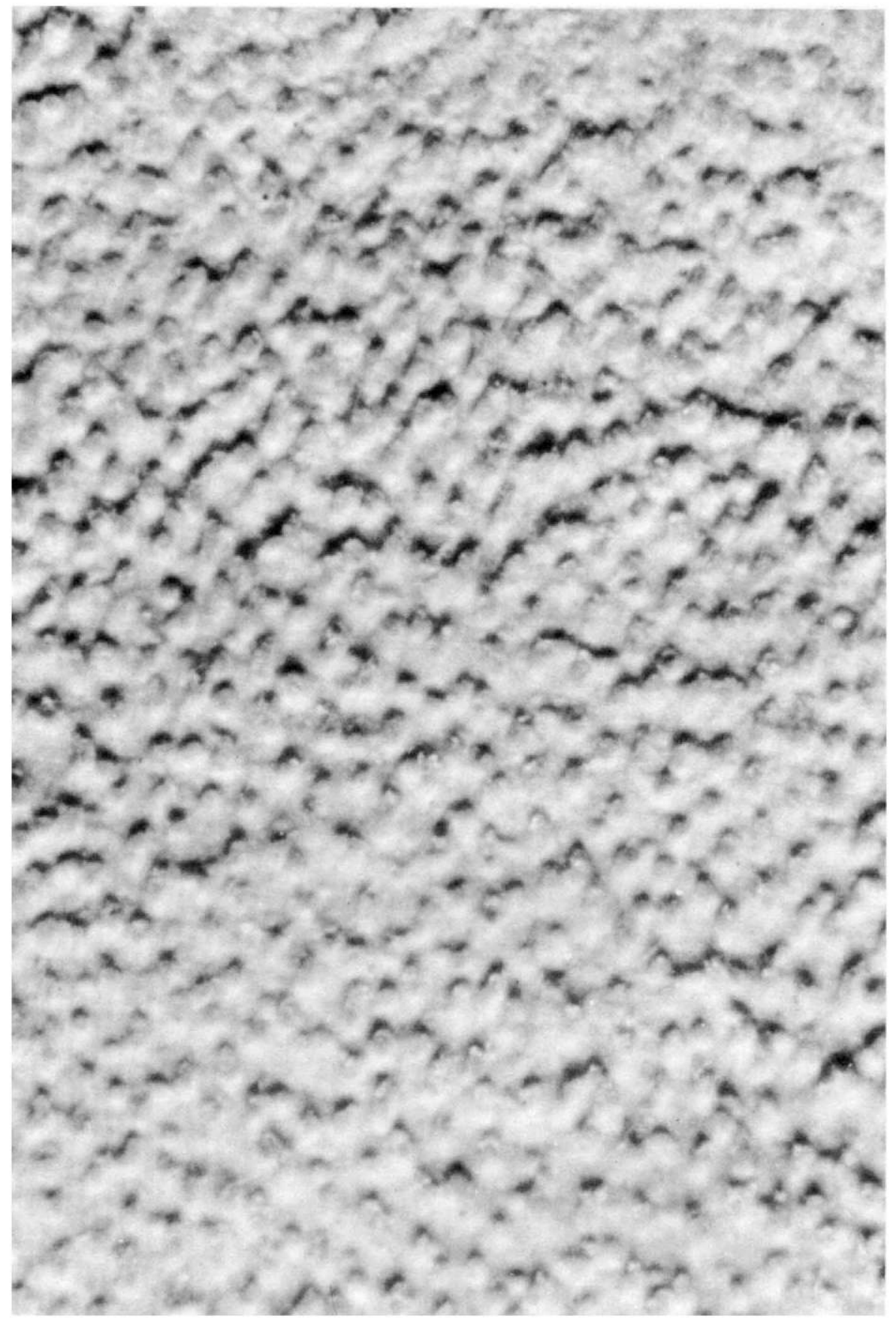

Plate 33.-Surface of skin from back of $144 \mathrm{~g}$. fetus; each bump the site of a hair about to erupt; specimen removed from formalin to alcohol; now partly dried; posterior end of body at top of photo; $\times 40$.

(3910) 


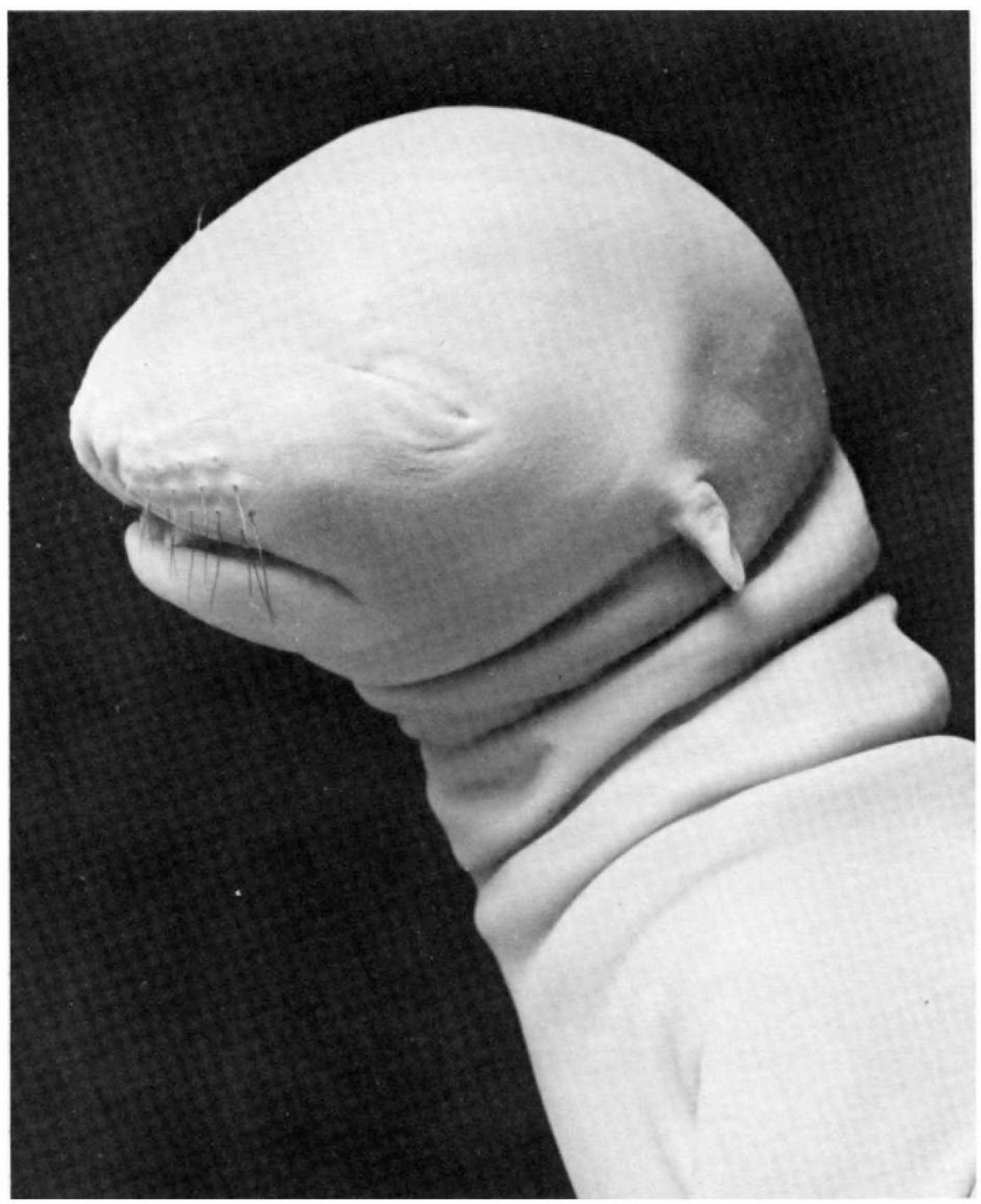

Plate 34.-Fetus of 260 g.; 19 January; when first, almost invisible, hairs are appearing on face and head; superciliary and mystacial vibrissae well developed.

(3859) 

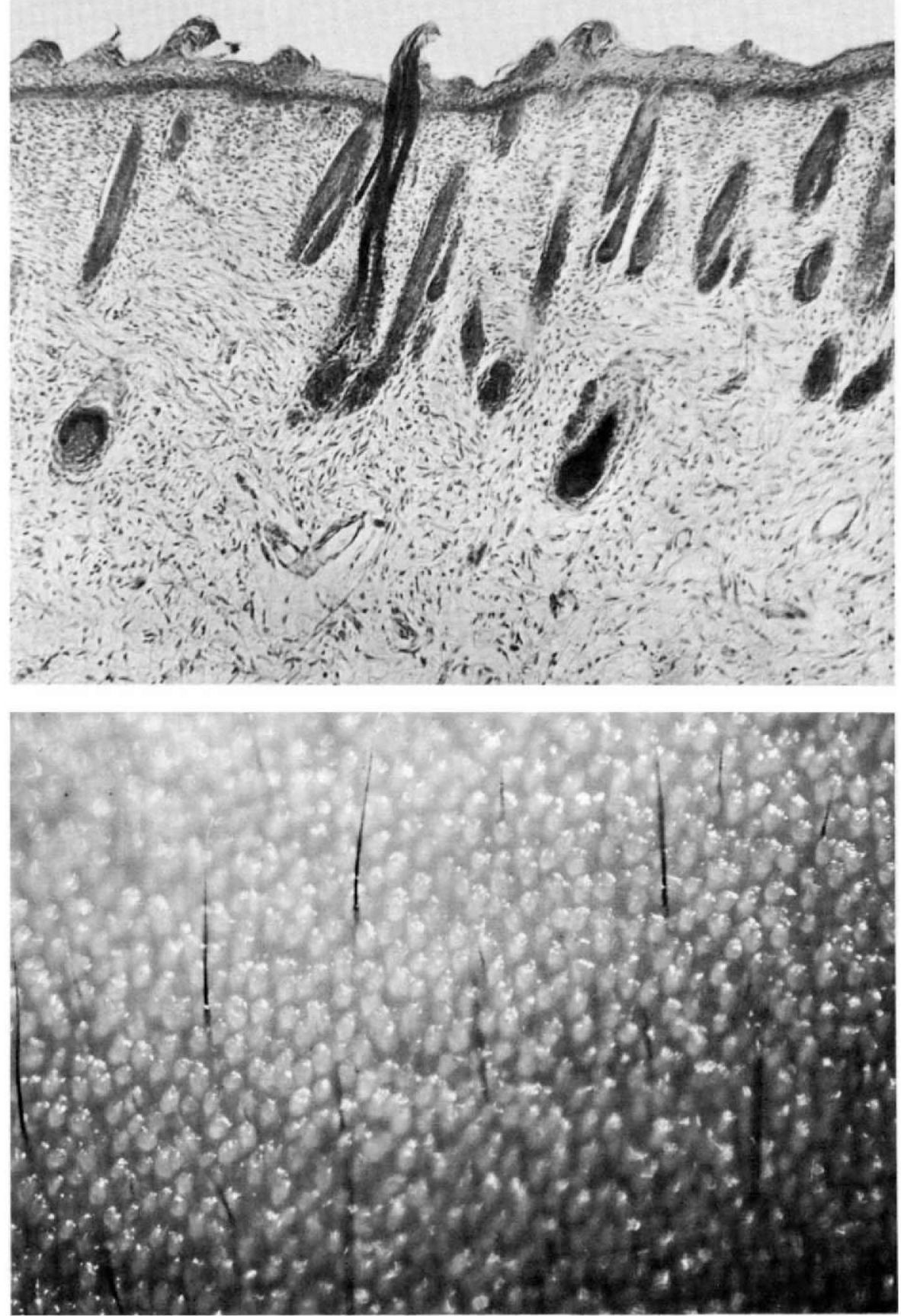

Plate 35.-Earliest pelage, on cheek-skin of $260 \mathrm{~g}$. fetus. (Above) Median section showing roots; $\times 100$. (Below) Surface view showing shafts of several hairs and many whitish bumps indicating sites of other hairs about to erupt; posterior end at top; $\times 25$.

(4168 and 4123) 


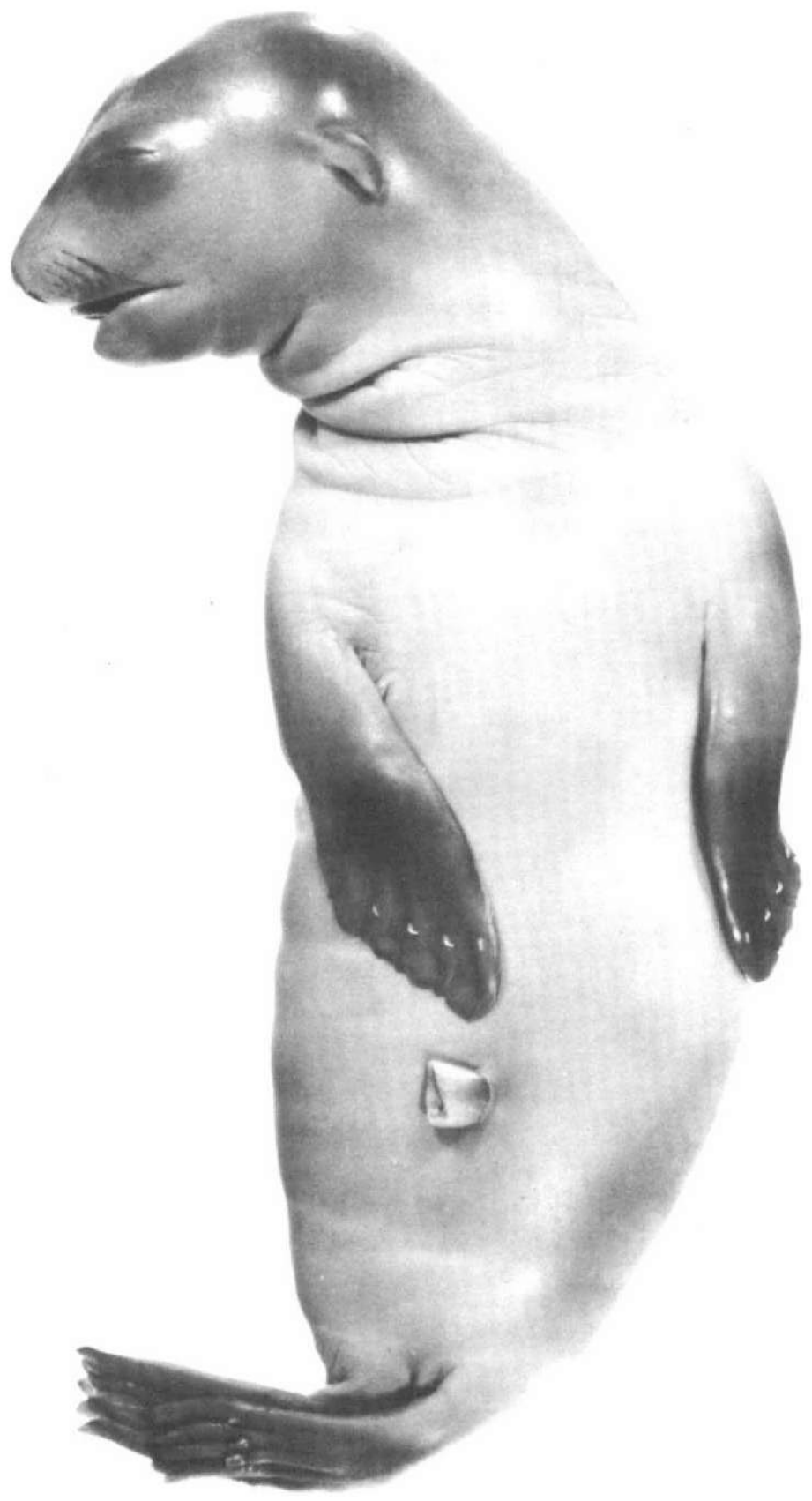

P'LATE 36.-Body of fetus, weight $372 \mathrm{~g}$. ; standard length $255 \mathrm{~mm}$. ; female; photographed in fresh condition out of mother killed 16 February and held on ice until 23 February.

(1802 A) 


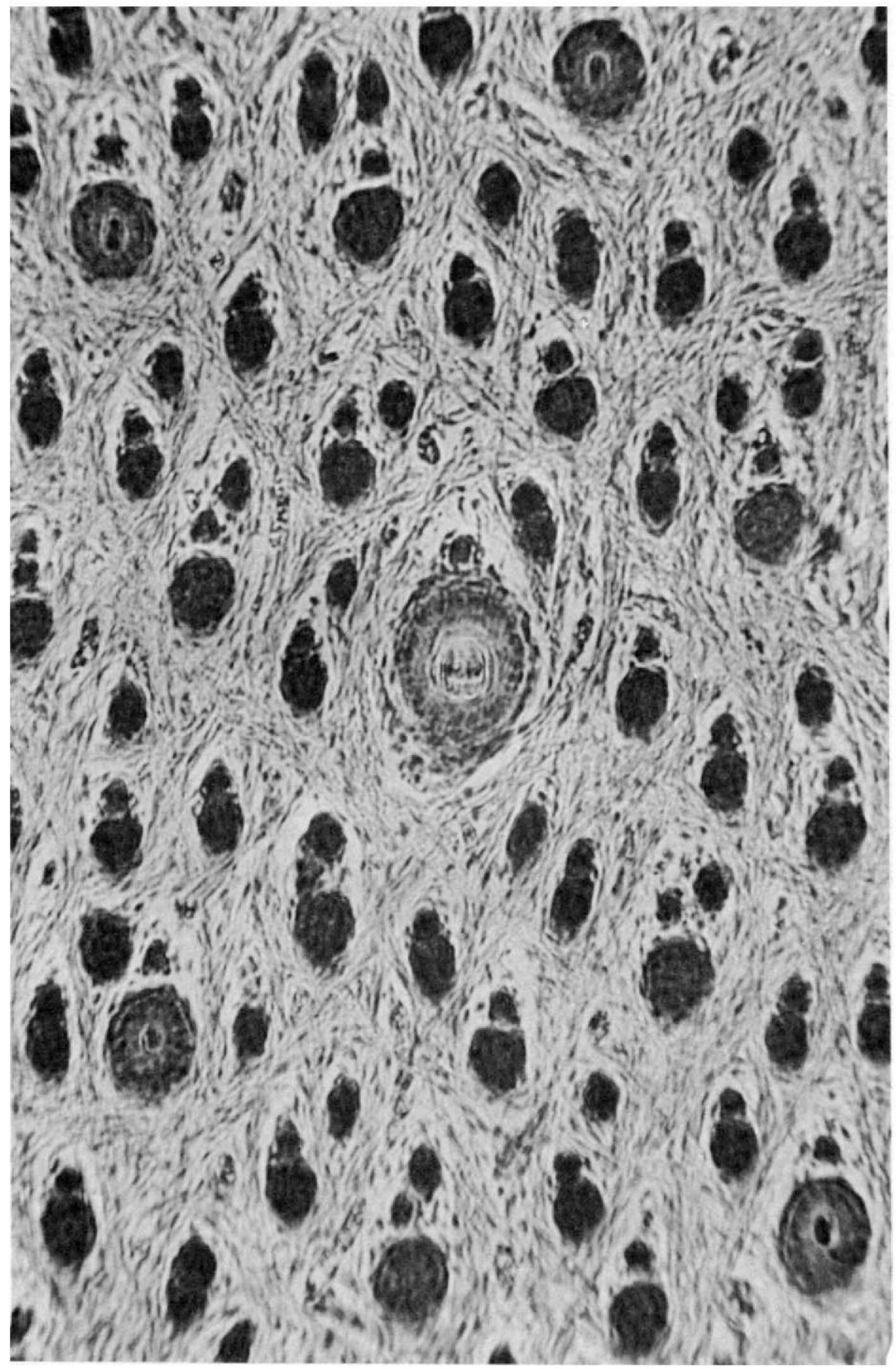

Puate 37.-Horizontal section, at depth of about $0.1 \mathrm{~mm}$., from back of neck of $575 \mathrm{~g}$. fetus ; posterior end at top; $\times 200$. The 5 large objects are hair follicles ; the numerous small dark ones may be (?) underhair primordia.

(4191) 


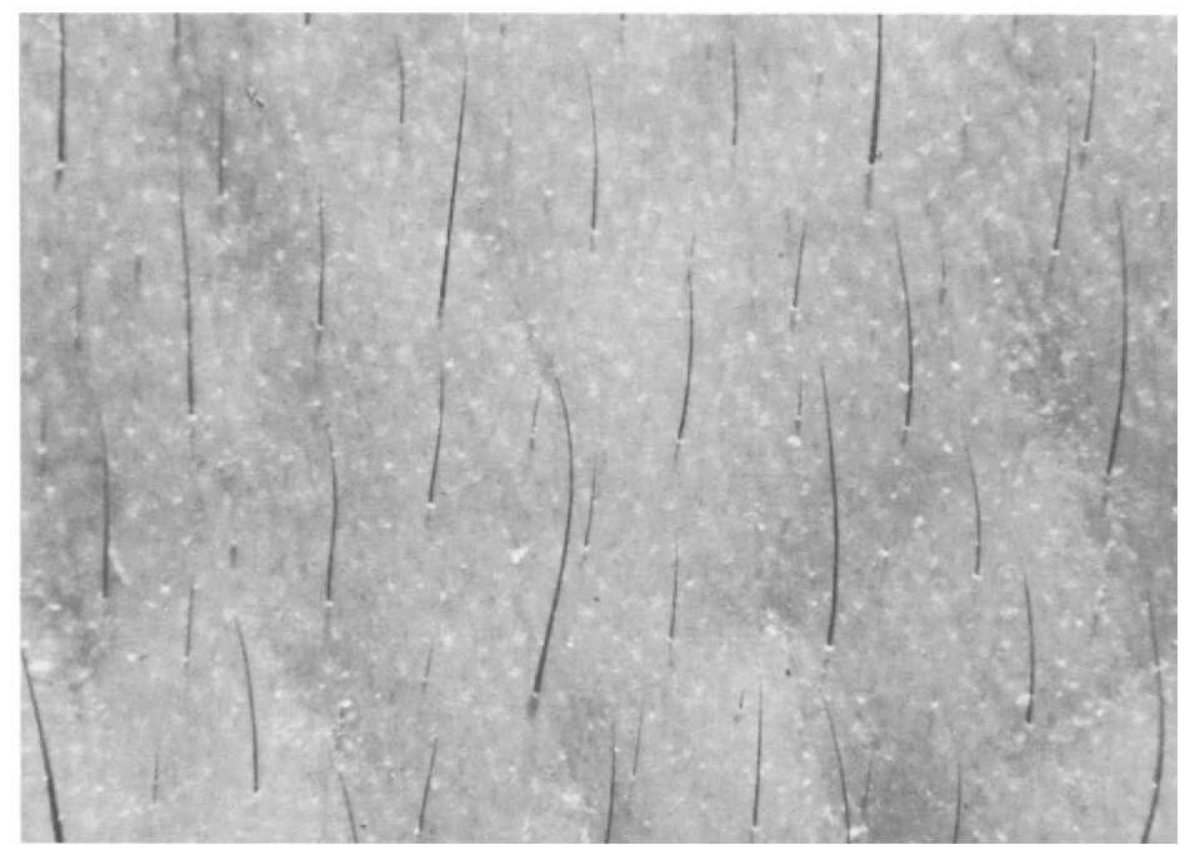

Plate 38-A.-Underhairs erupting on back of $660 \mathrm{~g}$. fetus ; $\times 25$.

(3926)

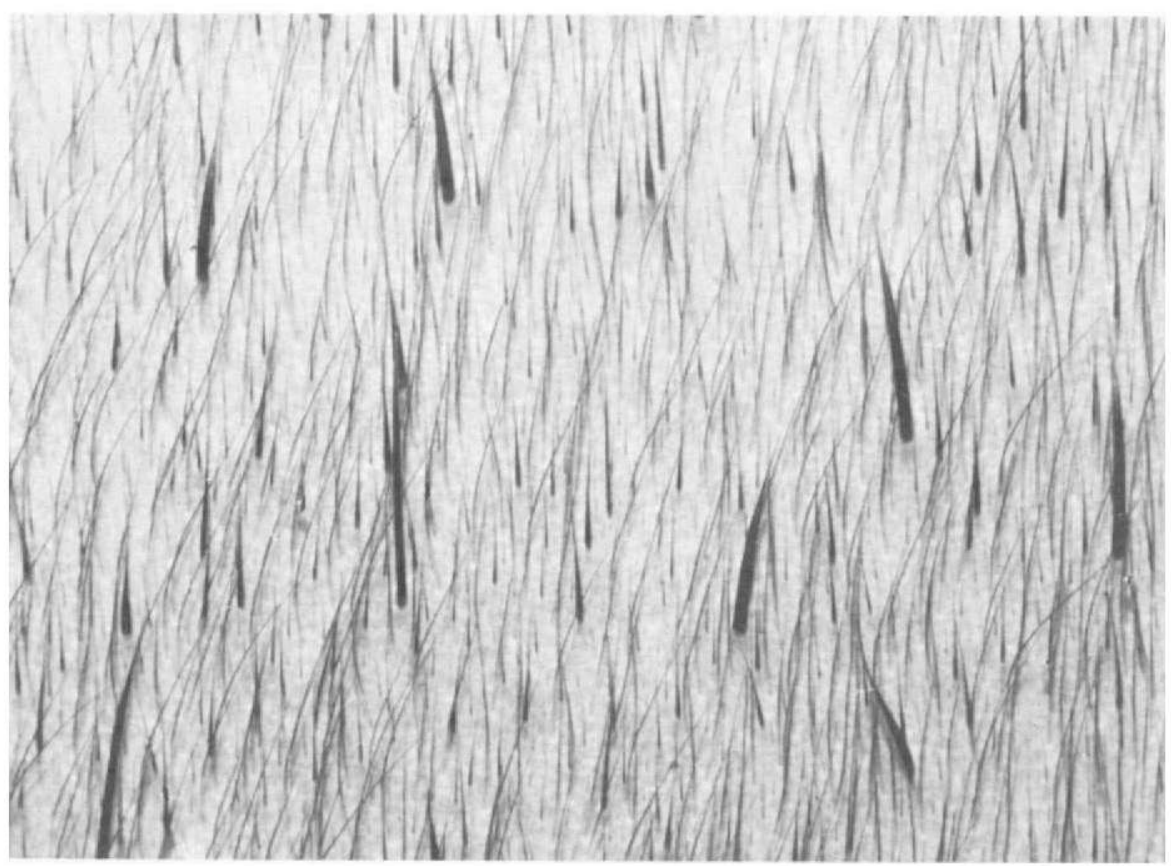

[2LATE 38-B.-Large, coarse guard hairs beginning to appear in field of smaller guard-hair tips and underhairs; on back of $1.93 \mathrm{~kg}$. fetus; $\times 10$. 


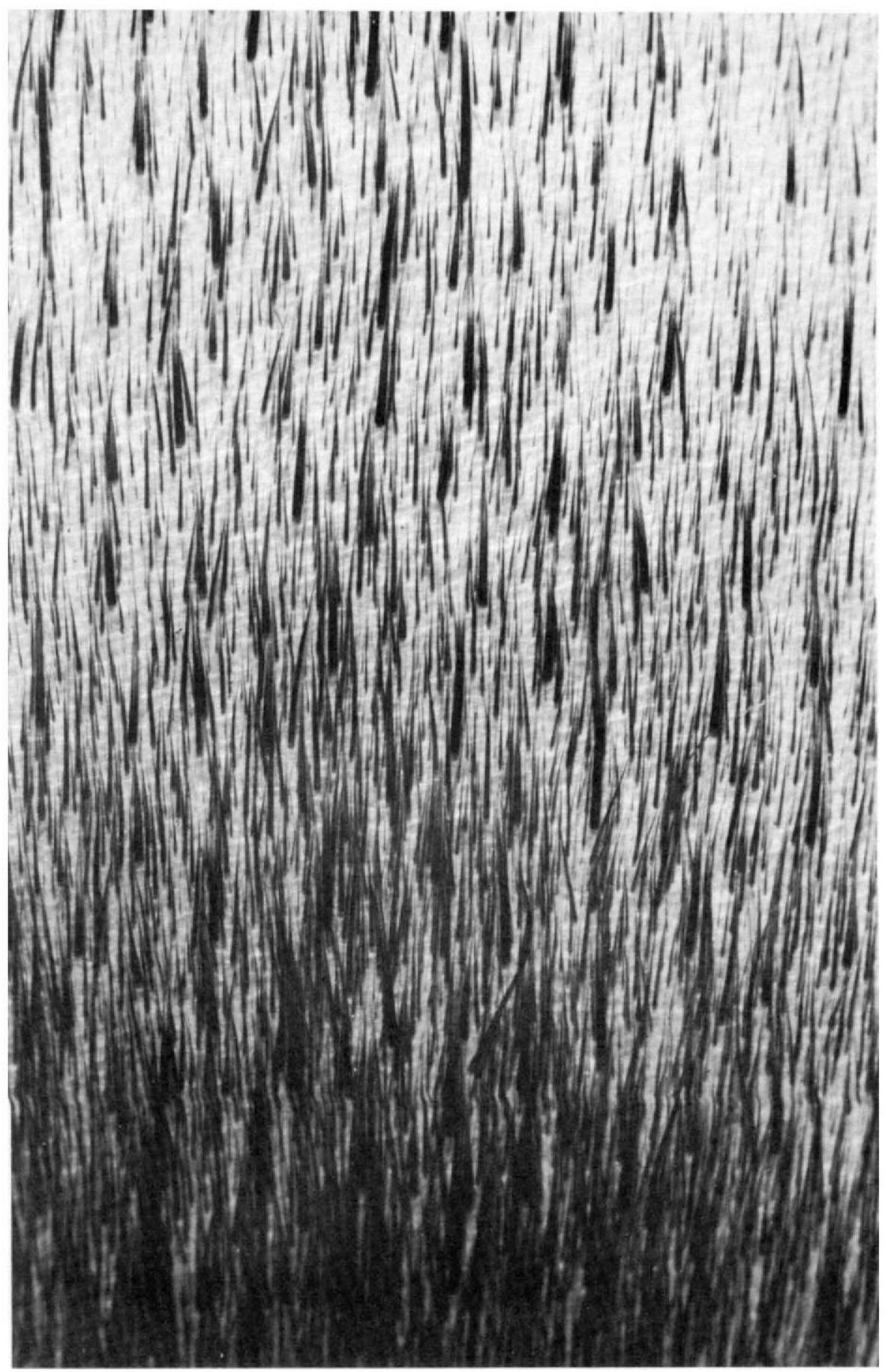

Plate 39.-Developing underhairs and guard hairs on back of neck of $1.45 \mathrm{~kg}$. fetus; earlier growth at anterior end (bottom of photo) ; $\times 10$. 


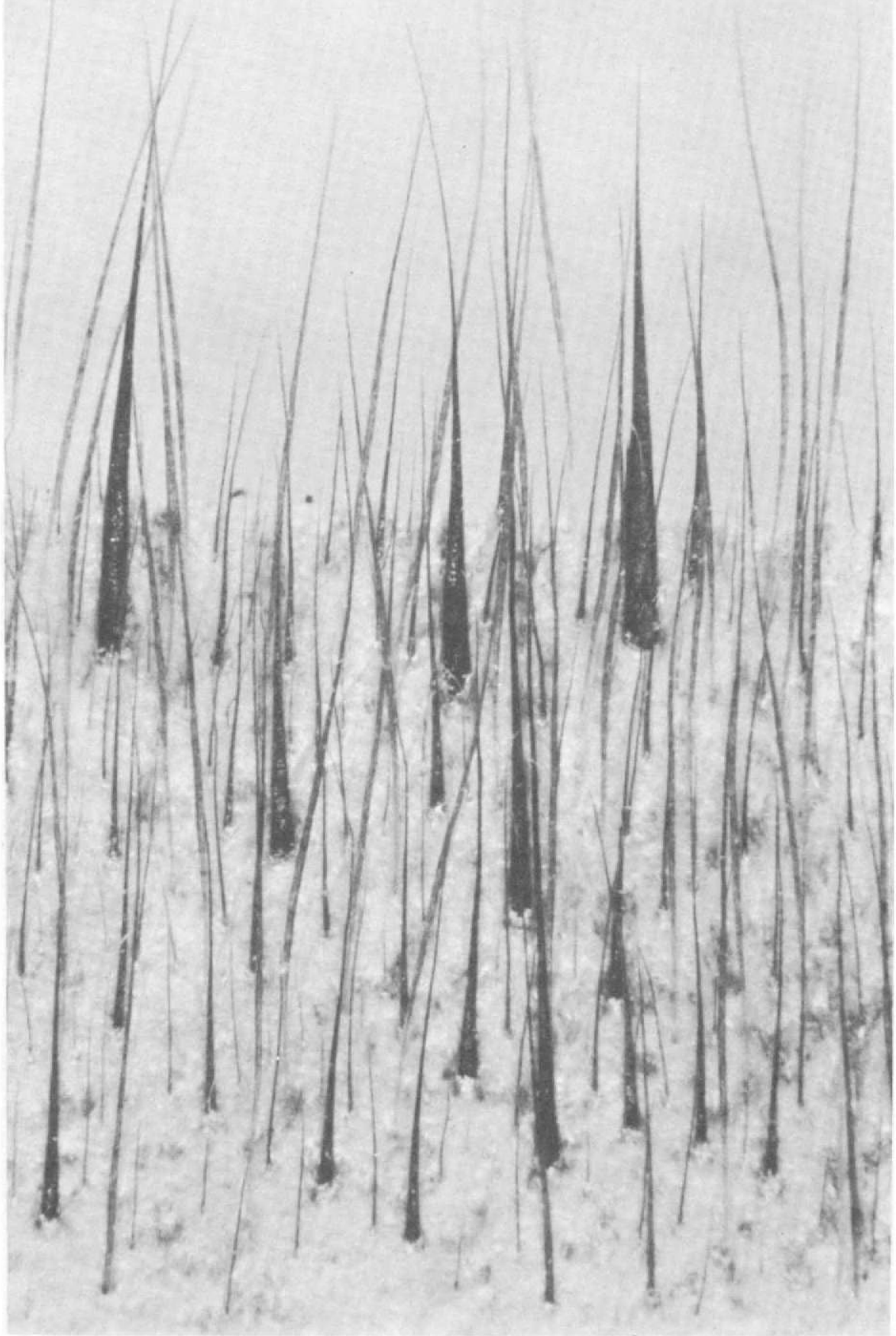

Plate 40.-Pelage developing on back of $2.21 \mathrm{~kg}$. fetus; $2 \mathrm{May}$; anterodorsal view; $\times 50$.

(3931) 


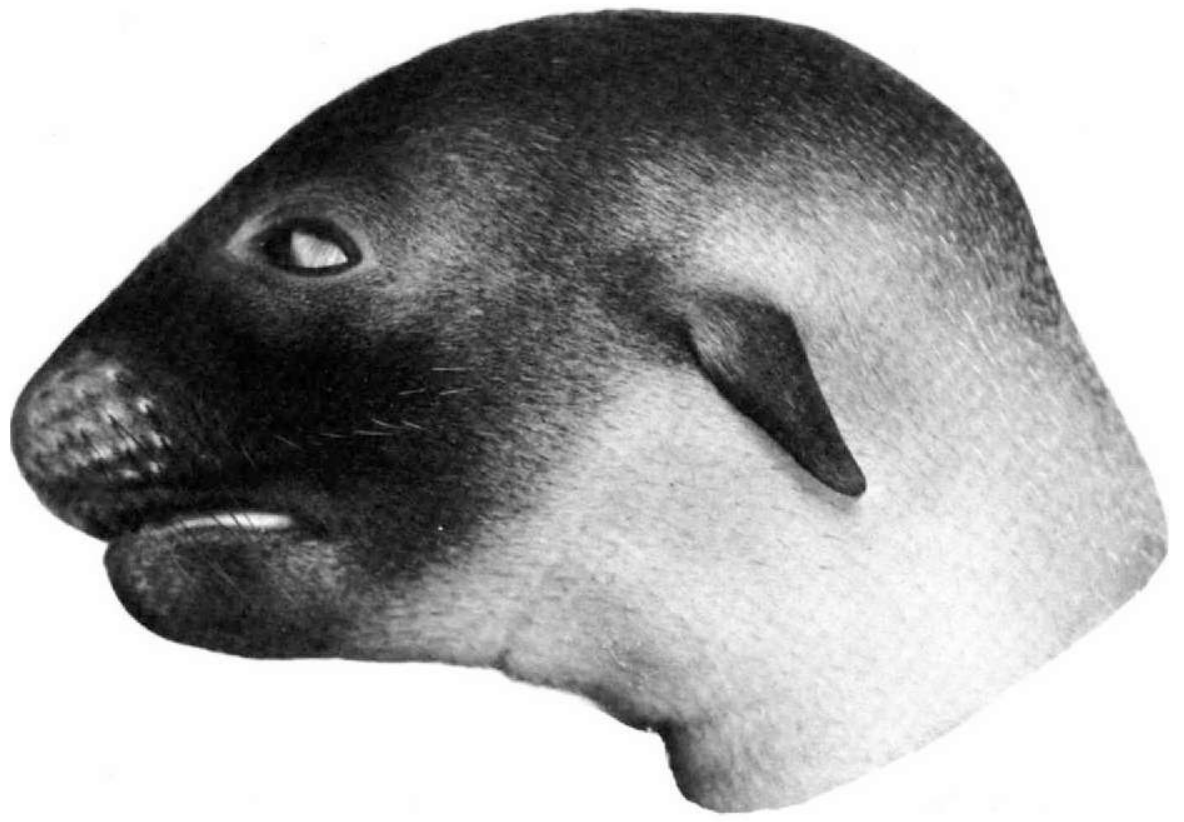

Plate 41-A.-Head of $1.7 \mathrm{~kg}$. fetus; natural size.
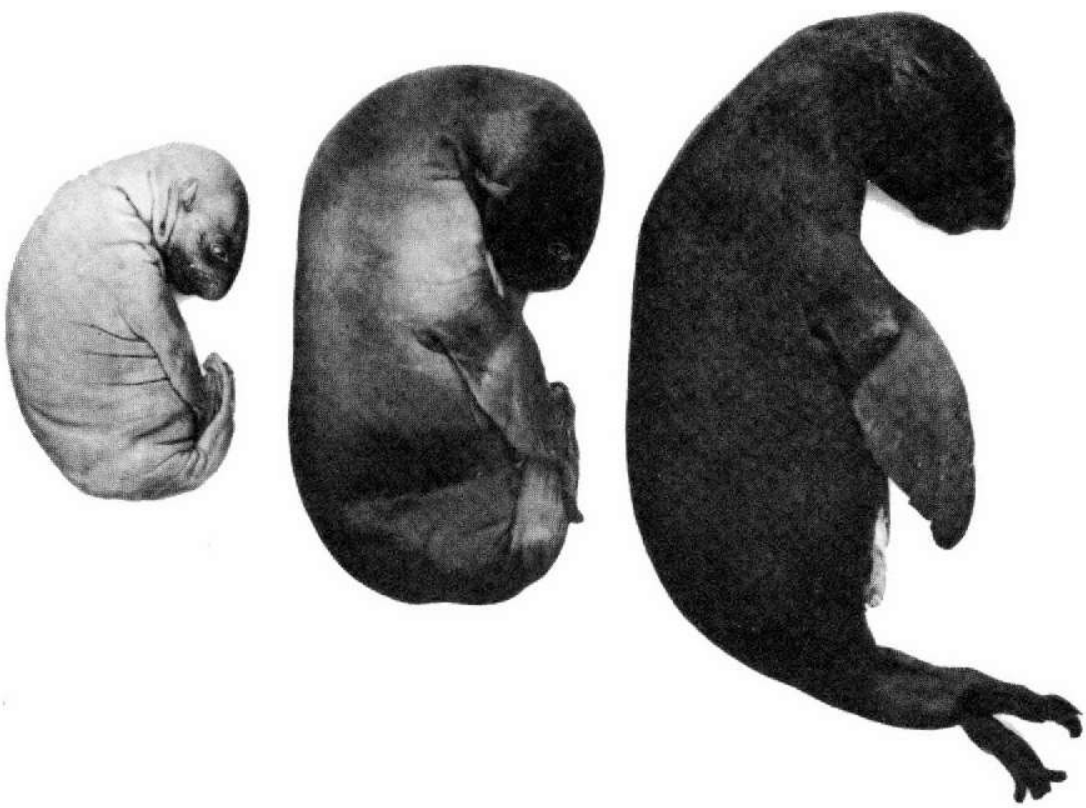

PLATE 41-B.-Three male fetuses showing pelage development; $1.4 \mathrm{~kg}$. (27 April); $2.7 \mathrm{~kg}$. (28 April); $3.7 \mathrm{~kg}$. (9 May).

(KWK 50-630) 


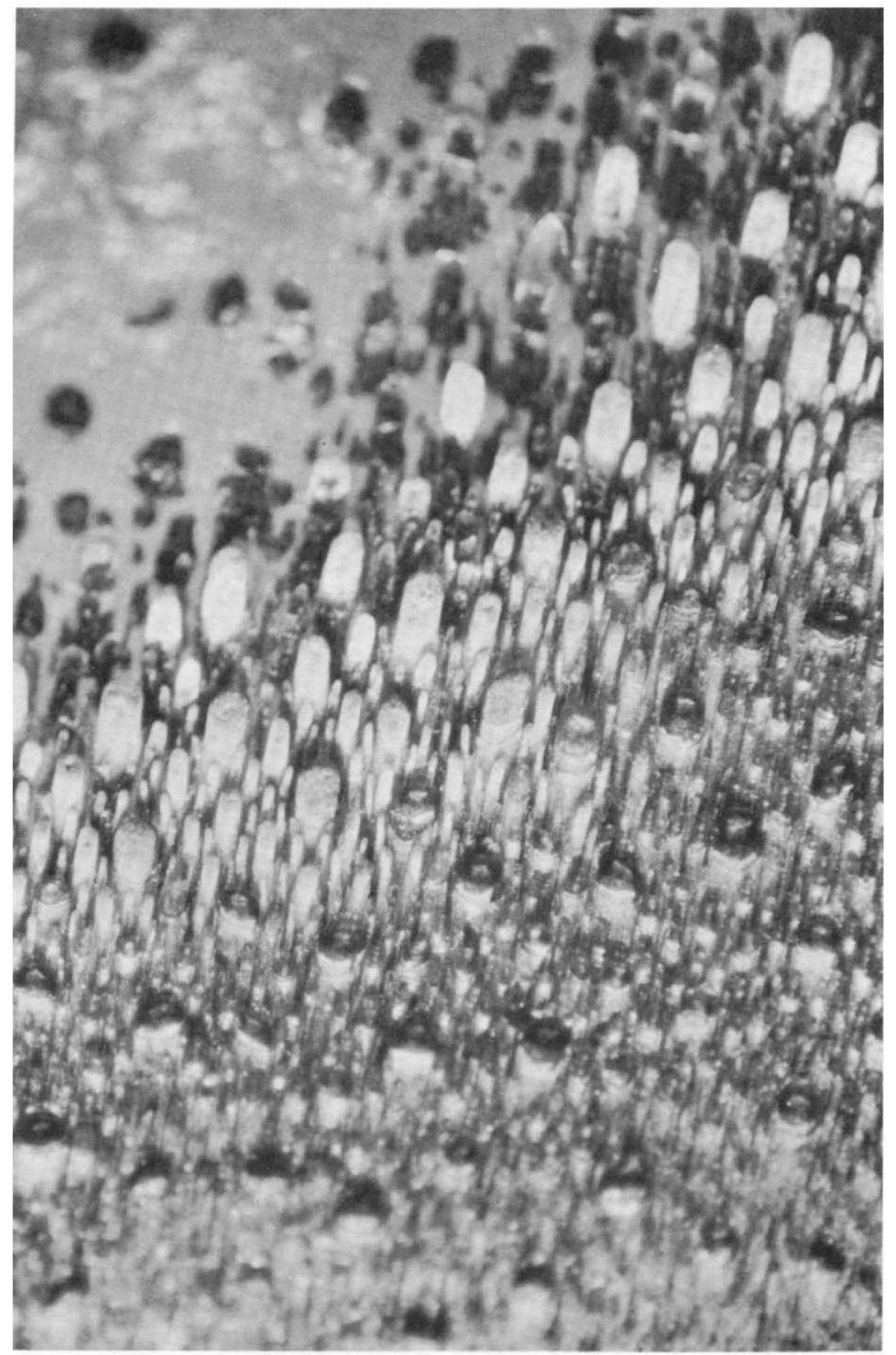

Plate 42.-Bases of developing underhairs and guard hairs on back of $2.44 \mathbf{~ k g}$. fetus ( 0.5 mean newborn weight) ; fibers shaved; partly dried; $\times 40$.

(3974) 

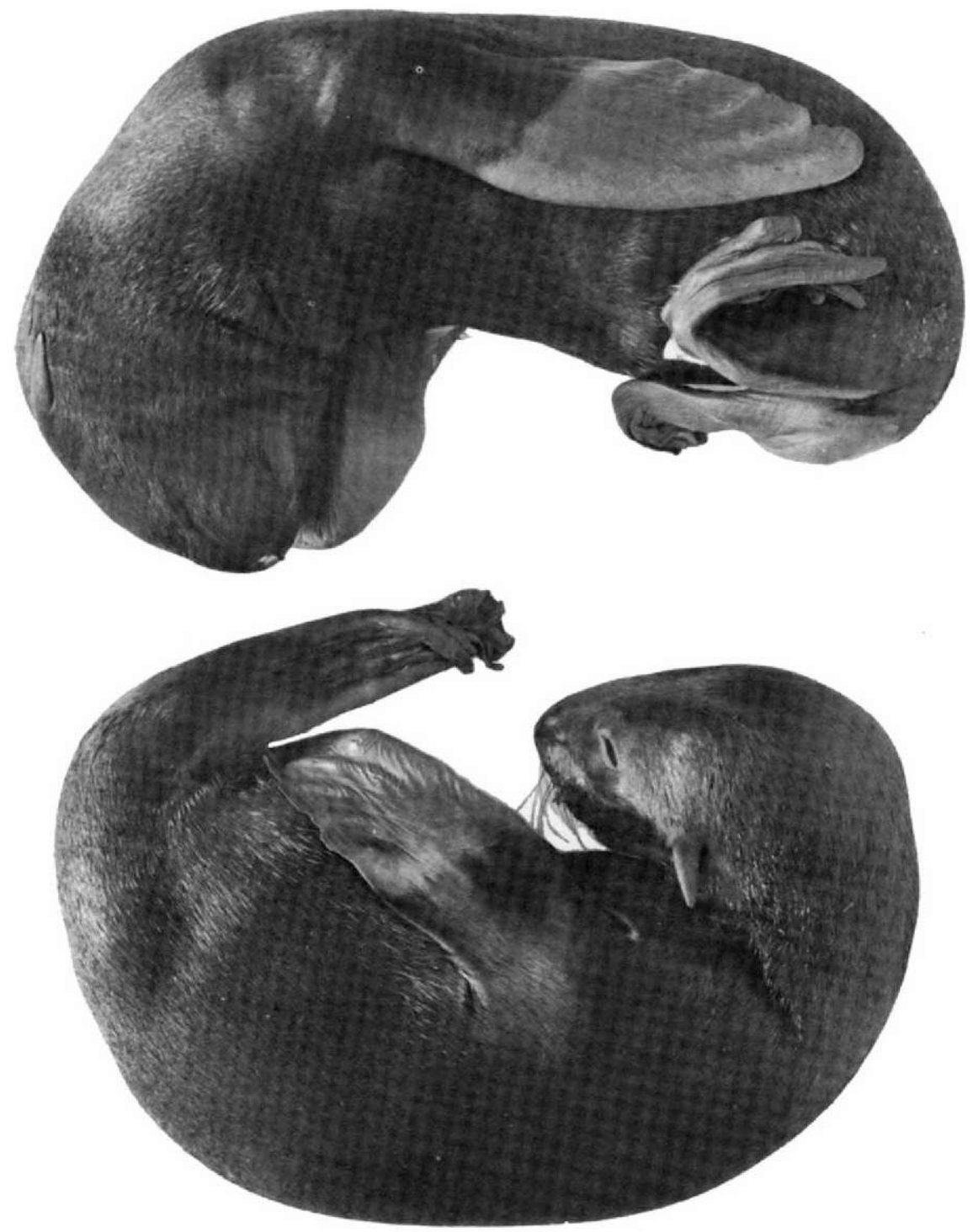

PLATE 43.-Twin fetuses of $9 \mathrm{May}$; removed from ateras preserved in formalin; $\times 0.33$. Each is a female in nearly mature birthcoat; one is $54 \mathrm{~cm}$. and $3.43 \mathrm{~kg}$. ; the other $53 \mathrm{~cm}$. and $3.49 \mathrm{~kg}$.

(4017) 

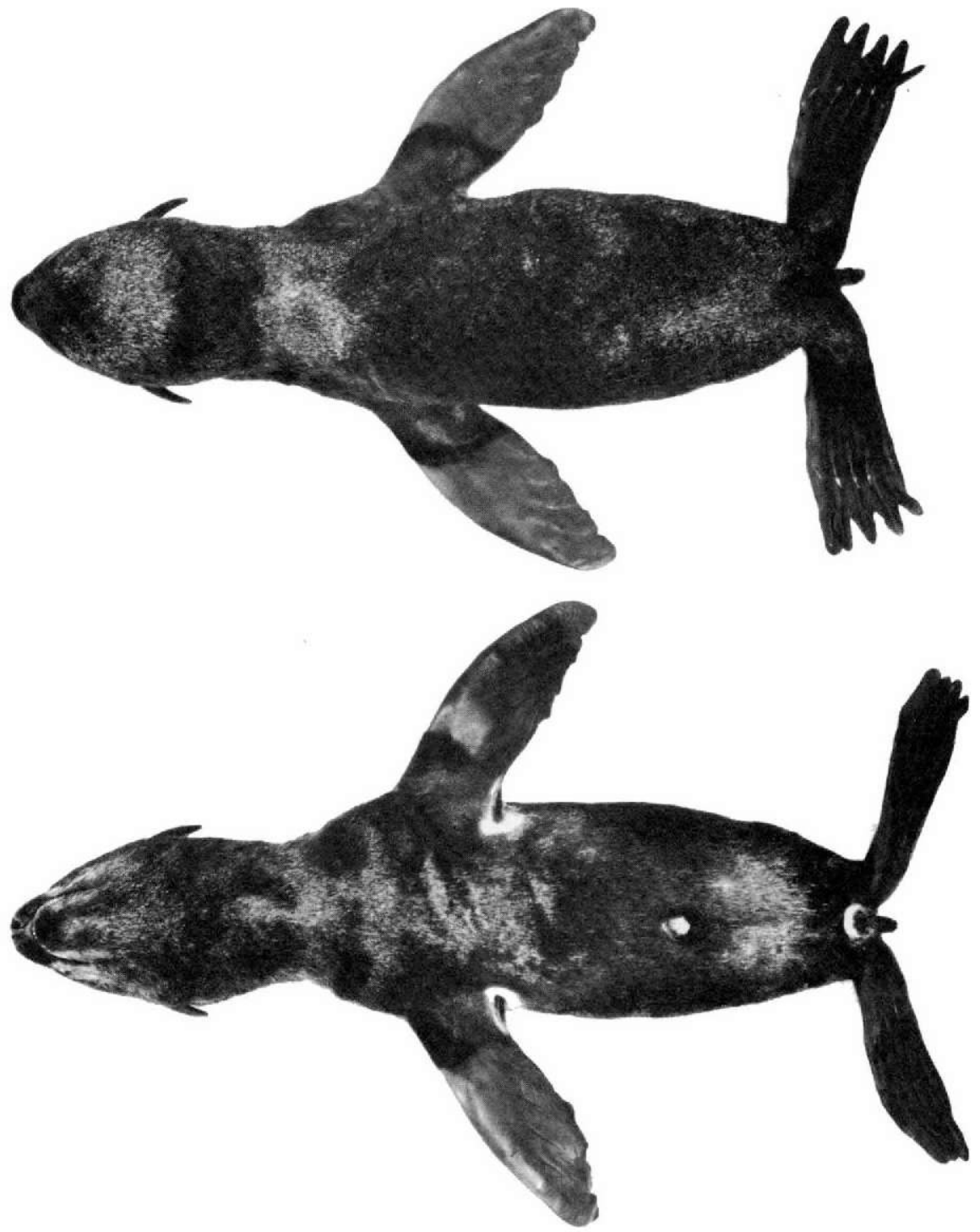

Plate 44.-Full-term fetus; female; weight $3.3 \mathrm{~kg}$., length $54 \mathrm{~cm}$. 6 July; pelage glossy black.

(1682 and 1683) 


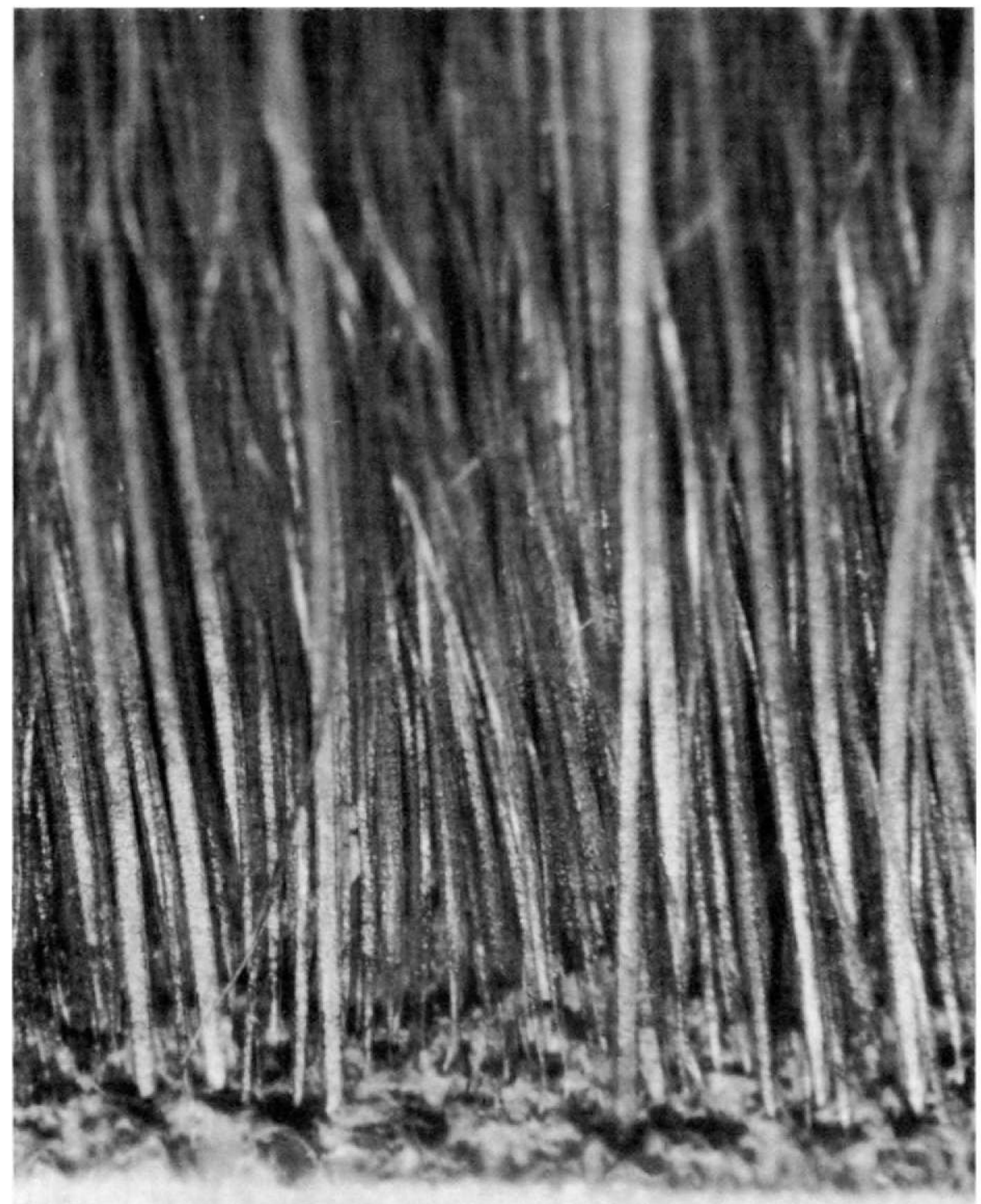

PLATE 45.-Black pup, newborn female; anterodorsal view of hair shafts rising from skin; formalin specimen; $\times 40$. Note coarse guard hairs and fine underhairs rising more or less independently.

(3937) 


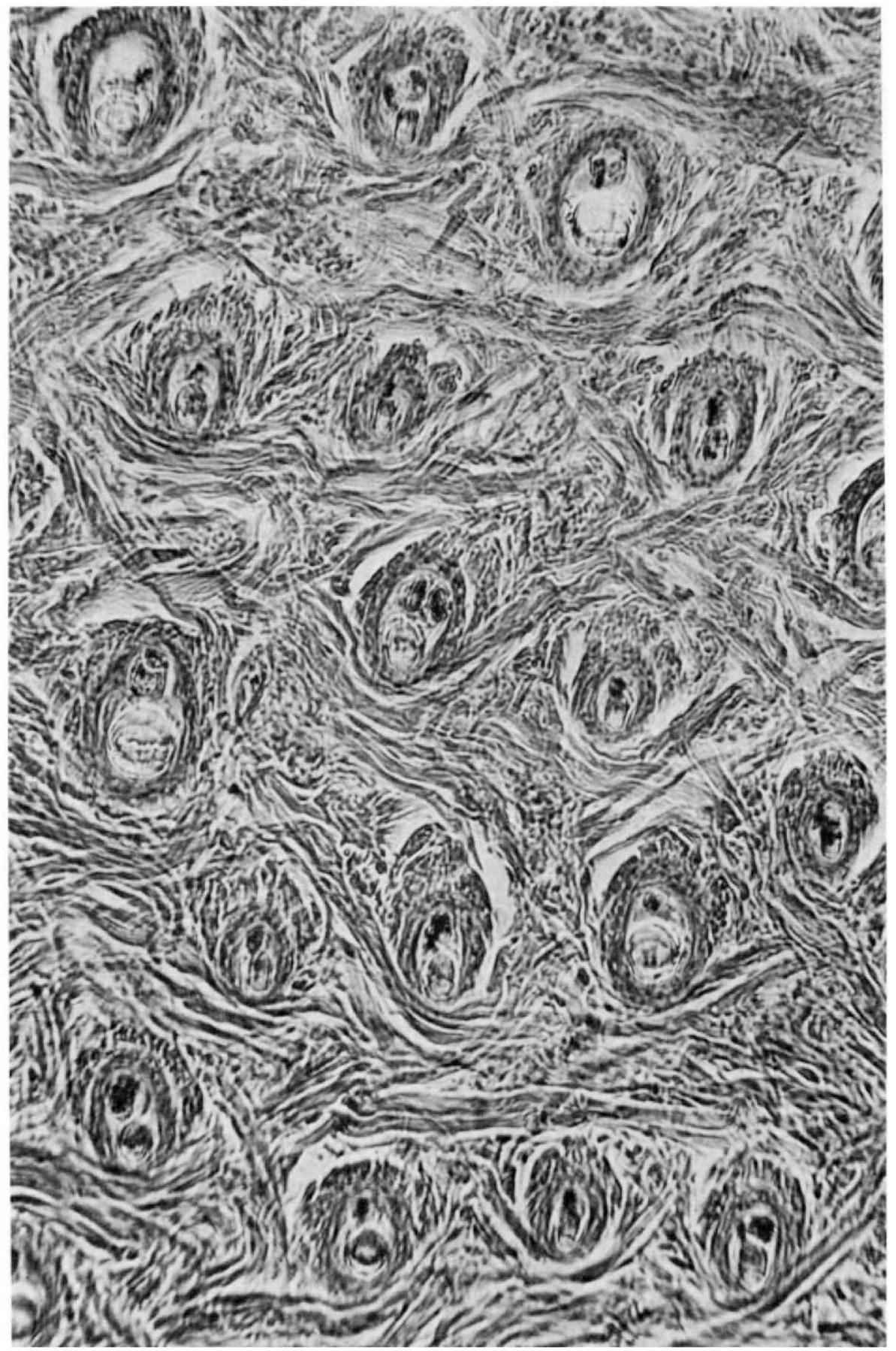

Plate 46.-Horizontal section, at depth of about $0.1 \mathrm{~mm}$., from back of neck of full-term fetus (black pup); posterior end at top; $\times 200$. Follicular bundles include 1,2 , or 3 hairs; the anterior one a guard hair. 


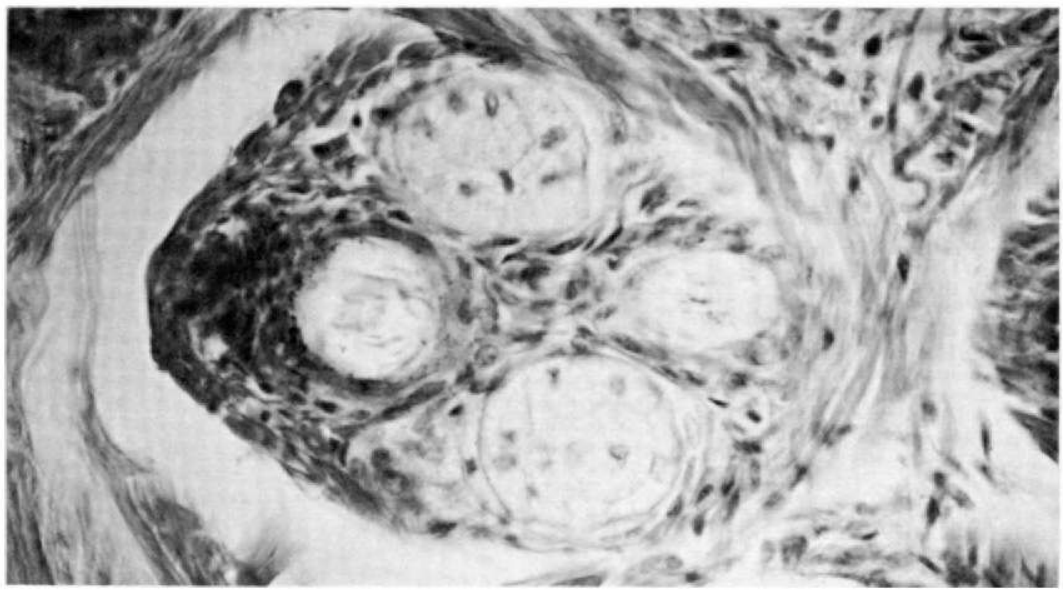

Plate 47-A.-(See pl. 46.) Section at depth of about $0.2 \mathrm{~mm}$. ; through one follicular bundle; $\times 400$. Note guard hair at right, underhair at left, and sebaceous glands above and below.

(4195)

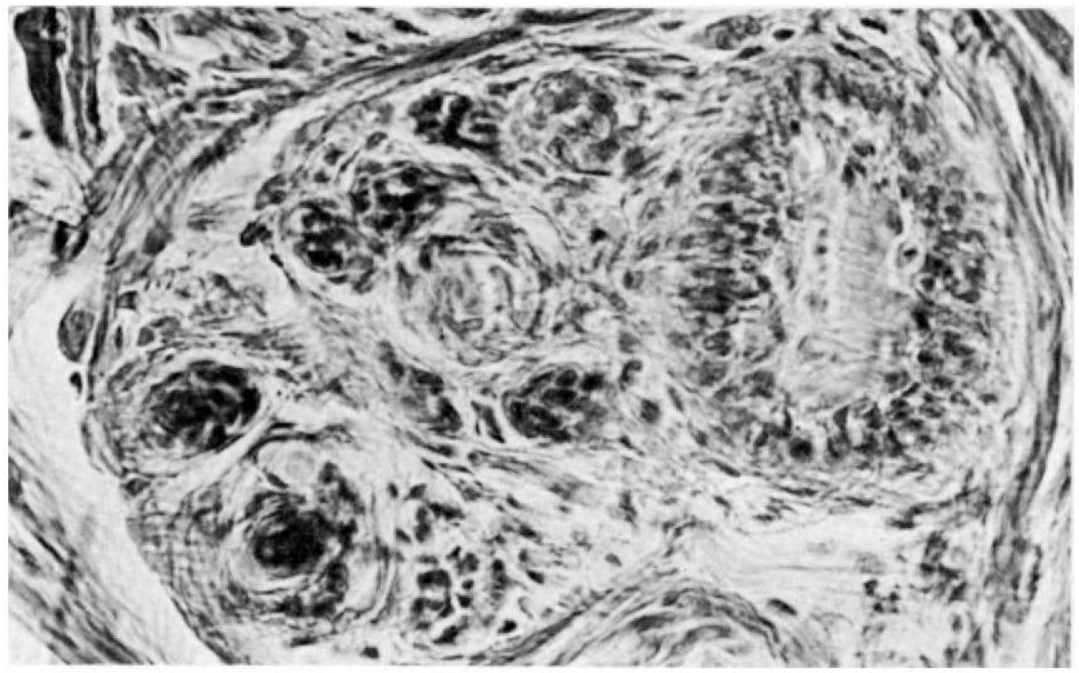

Plate 47-B.-(See pl. 46.) Section at depth of about $0.8 \mathrm{~mm}$.; bulb of guard-hair follicle at right; bulb of underhair follicle at left, surrounded by primordia of adult-type underfur follicles; $\times 400$.

(4196) 


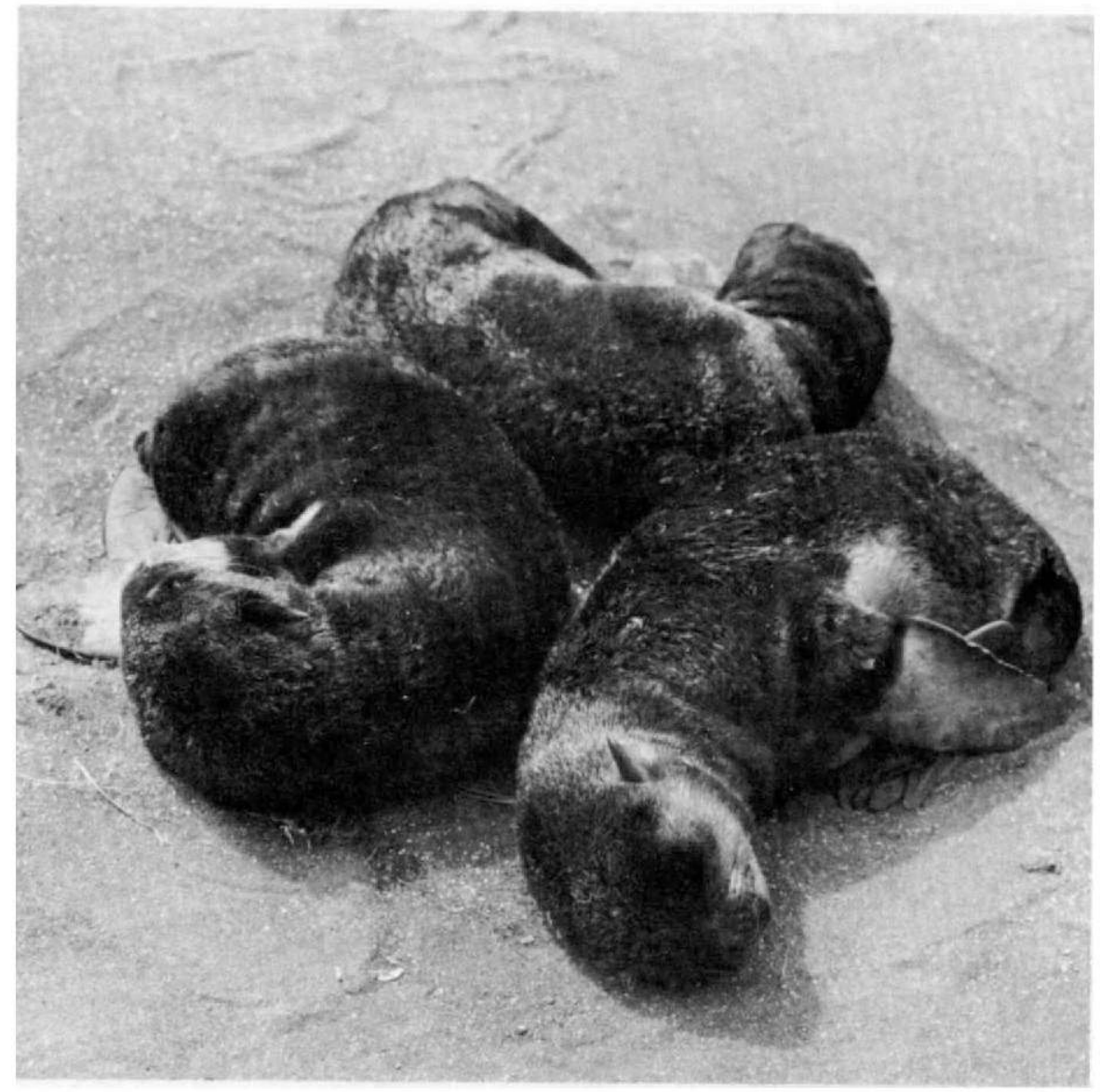

Plate 48.-Black pups, molting, on 29 July. Loose birtheoat fibers are blowing about on the sandy rookeries at this time of year.

(2250A) 


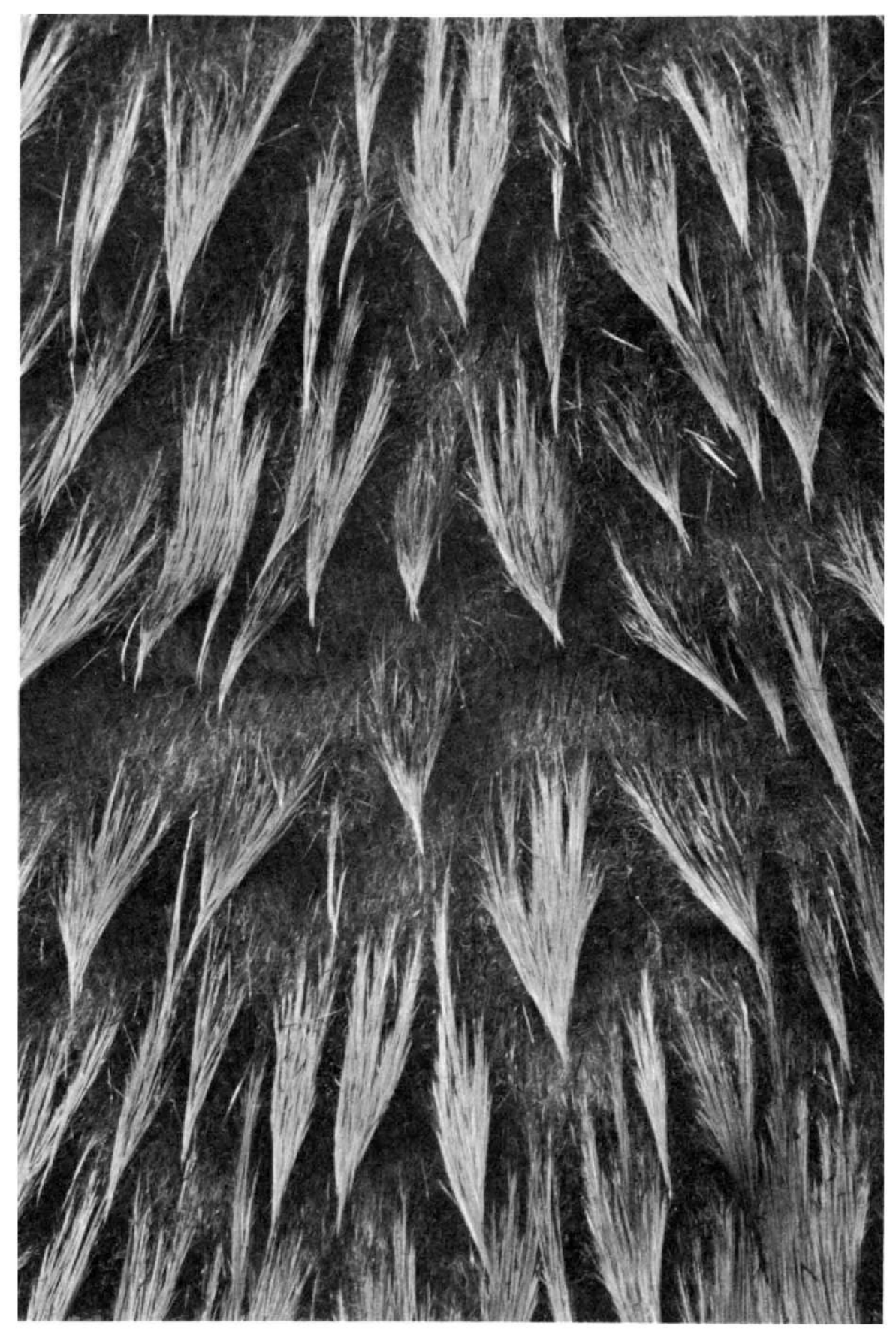

Plate 49.-Black pup, molting; approaching silver stage; 15 September; wet pelage of back of neck; $\times 2.3$. Pup had come out of ocean and shaken itself, and was sprawled on a rock. Guard hairs $20 \mathrm{~mm}$. in length; underhairs $11 \mathrm{~mm}$. (See plate 50.) 


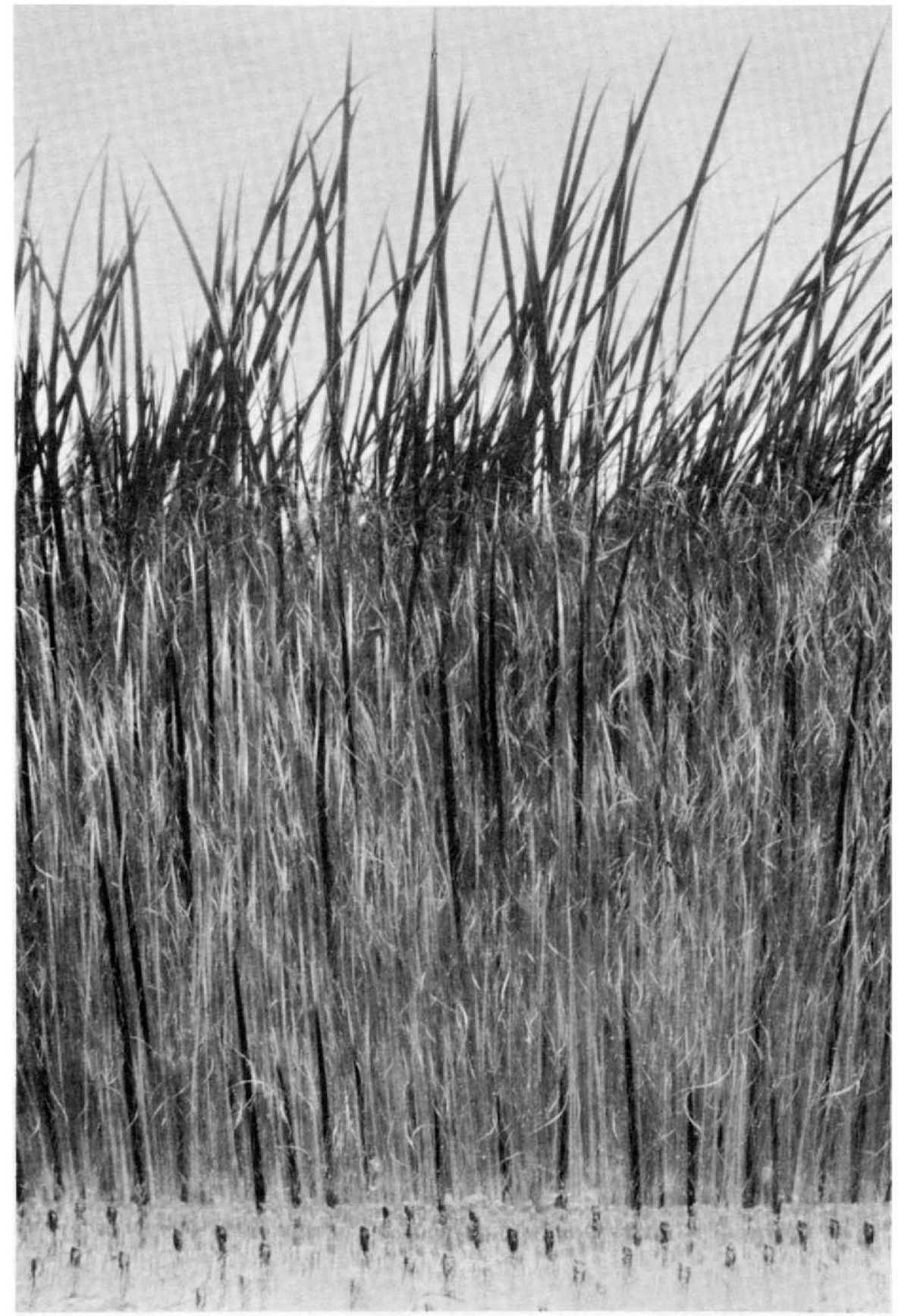

Plate 50.-Black pup, molting; 15 September; posteroventral view of fresh, dry pelage from back; $\times 8$. (Same specimen as shown in plate 49.) Pigmented roots of many adult-type guard hairs may be seen in the skin; adult-type underfur fibers are beginning to dominate the surface pelage.

(4142) 


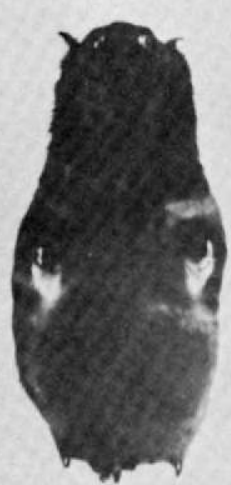

A

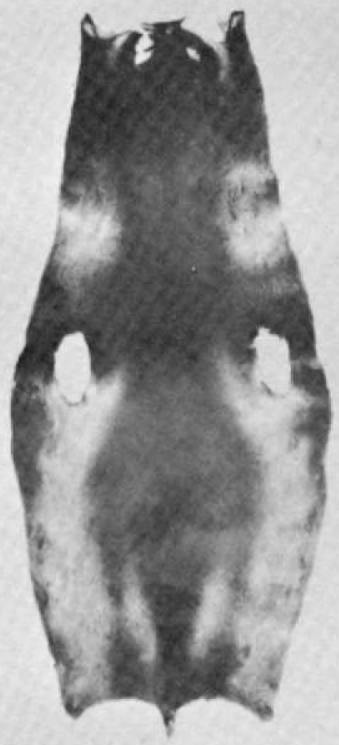

C

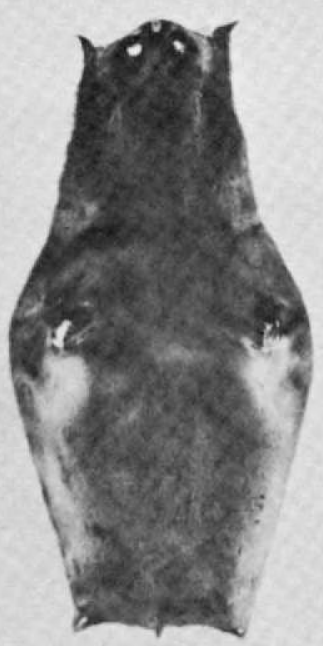

B

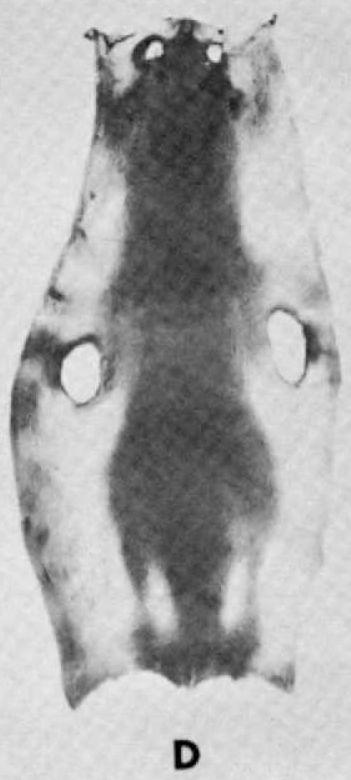

Plate 51.-Tanned pelts showing transition from birthcoat to first adult-type pelage. A.-black pup; newborn female; $12 \mathrm{July} ; 4.42 \mathrm{~kg}$. (9.75 lb.). B.-black pup; molting female; 11 August; $9.30 \mathrm{~kg}$. (20.5 lb.). C.-black pup; molting male; 29 September; $14.7 \mathrm{~kg}$. (32.5 lb.). D.-silver pup; autumn female; 13 October; $15.2 \mathrm{~kg}$. (33.5 lb.). 


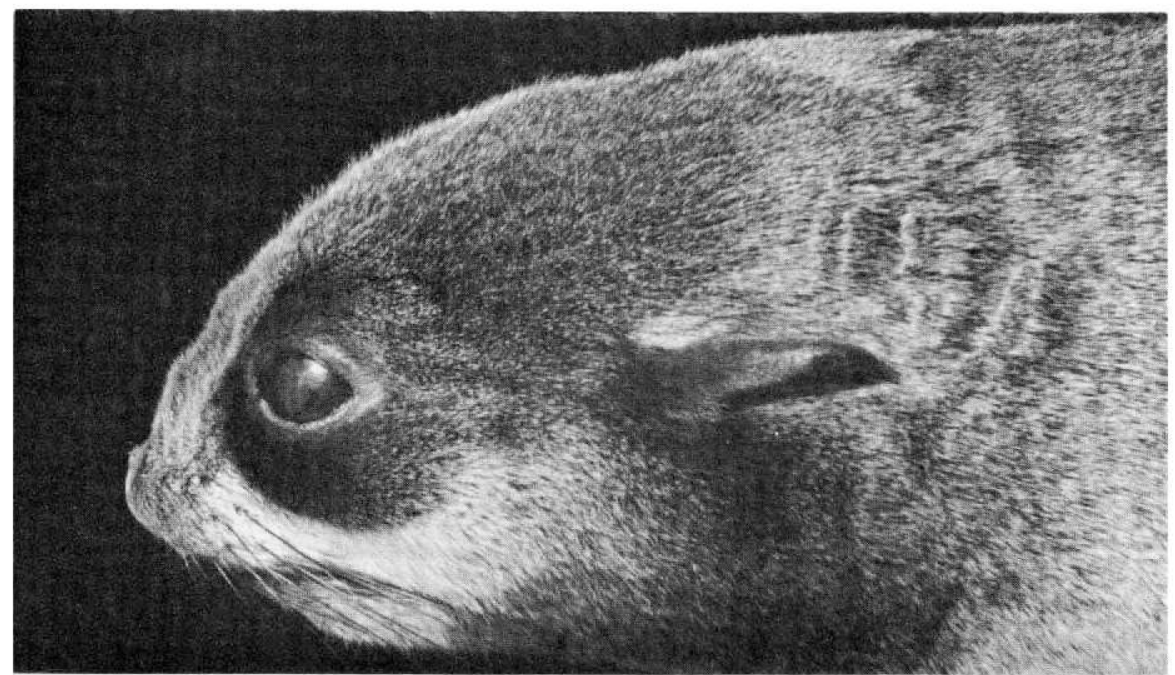

Puate 52-A.-Head of silver pup; male; 24 September; entire weight of animal $12.7 \mathrm{~kg}$. (28 lb.).

(4056)

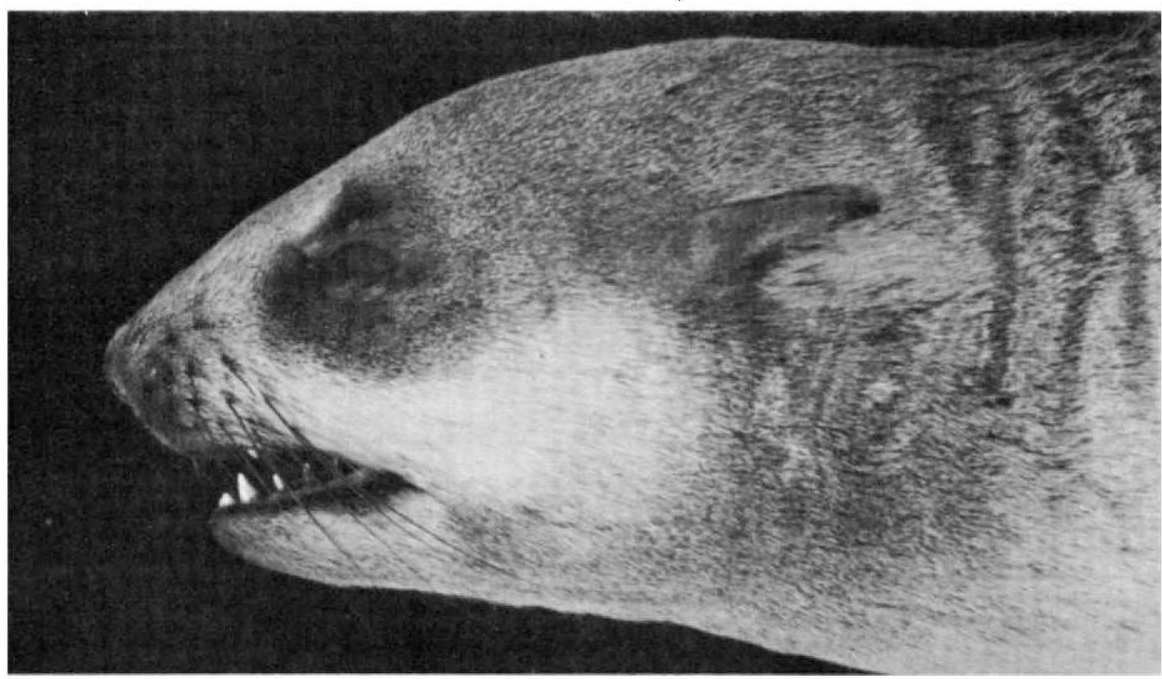

PLate 52-B.-Similar; female; 28 September; weight $11.8 \mathrm{~kg}$. (26 lb.).

(4086) 


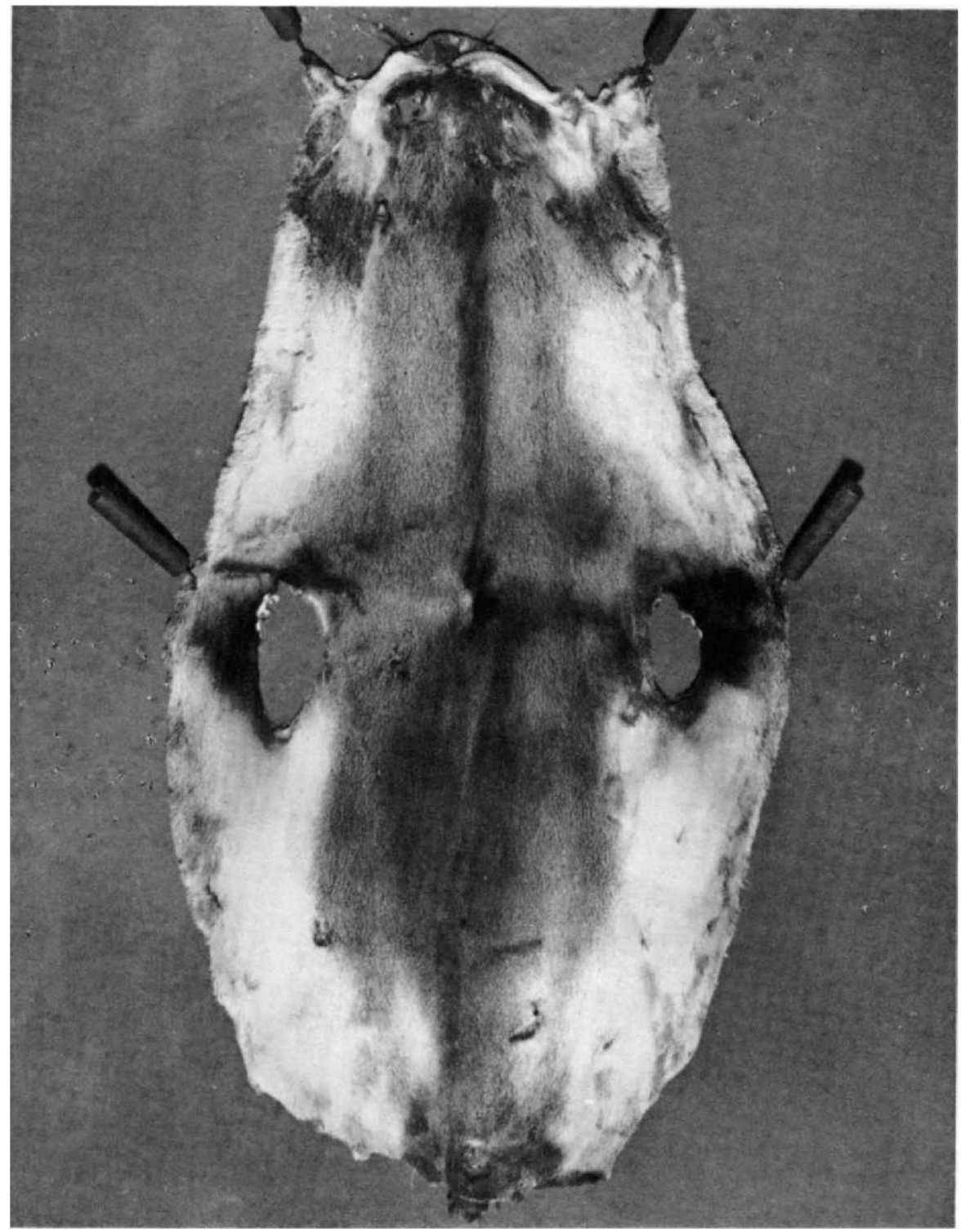

Plate 53.-Tanned pelt of yearling, pelagic; male; 25 April; $\times 0.2$. Compare with silver pup in pl. 52-A. Dark streak along back is an artifact, a result of folding. (4000 NWC 52-3656) 


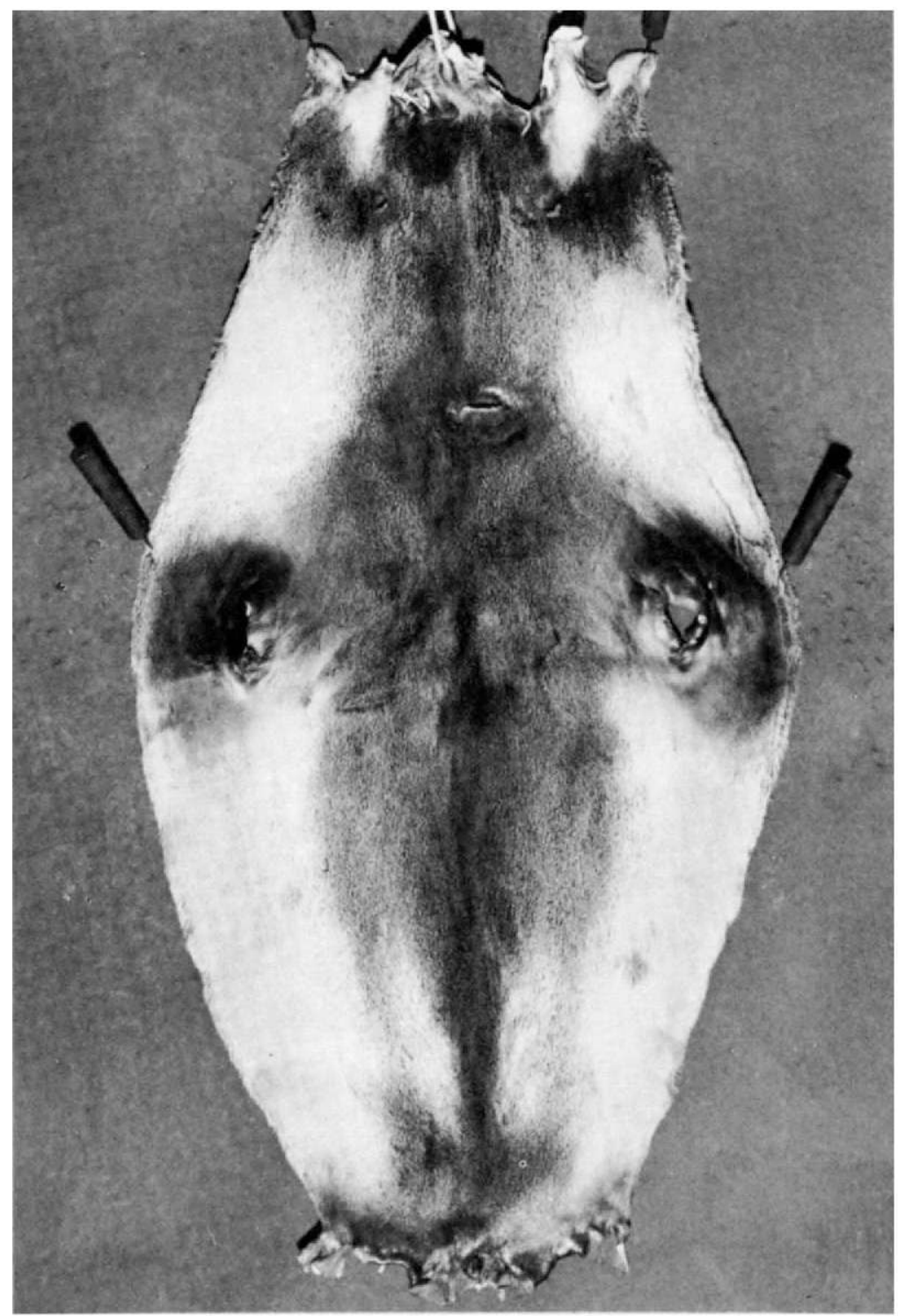

Plate 54.-Tanned pelt of yearling, autumn; female; 31 Oetober; in second adulttype pelage; $\times 0.2$.

(4000 BDM 25) 


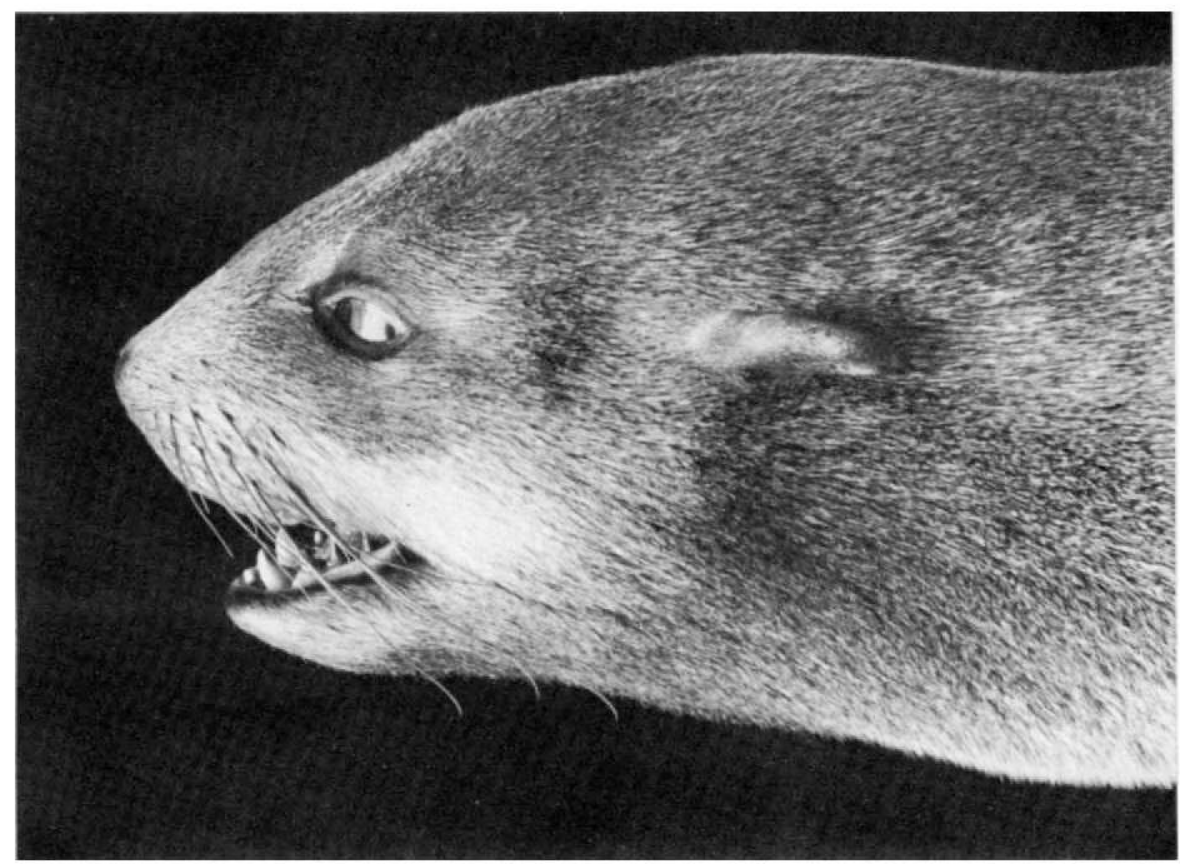

Plate 55-Head of yearling, autumn; male; 26 September.

$(4060)$ 


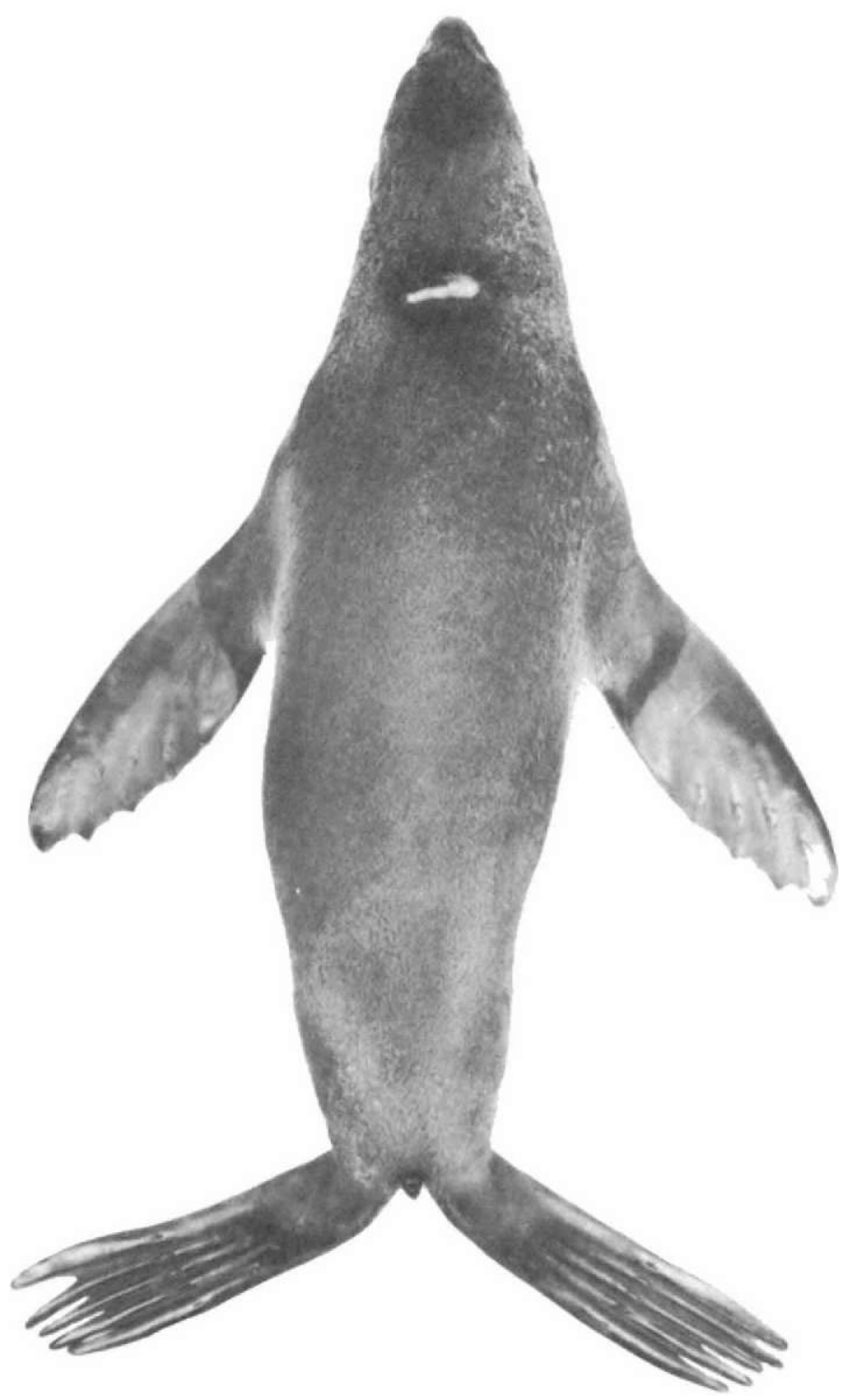

Plate 56.-Four-year-old male on 26 July, entering its 5th year of life and its 5th molt. This molt centers in October. Length $141 \mathrm{~cm}$. (55.5 in.); weight $51.2 \mathrm{~kg}$. (113 lb.) ; scar on neck represents hot-iron brand applied in first summer; dorsal view.

(1721) 


$$
\text { . }
$$




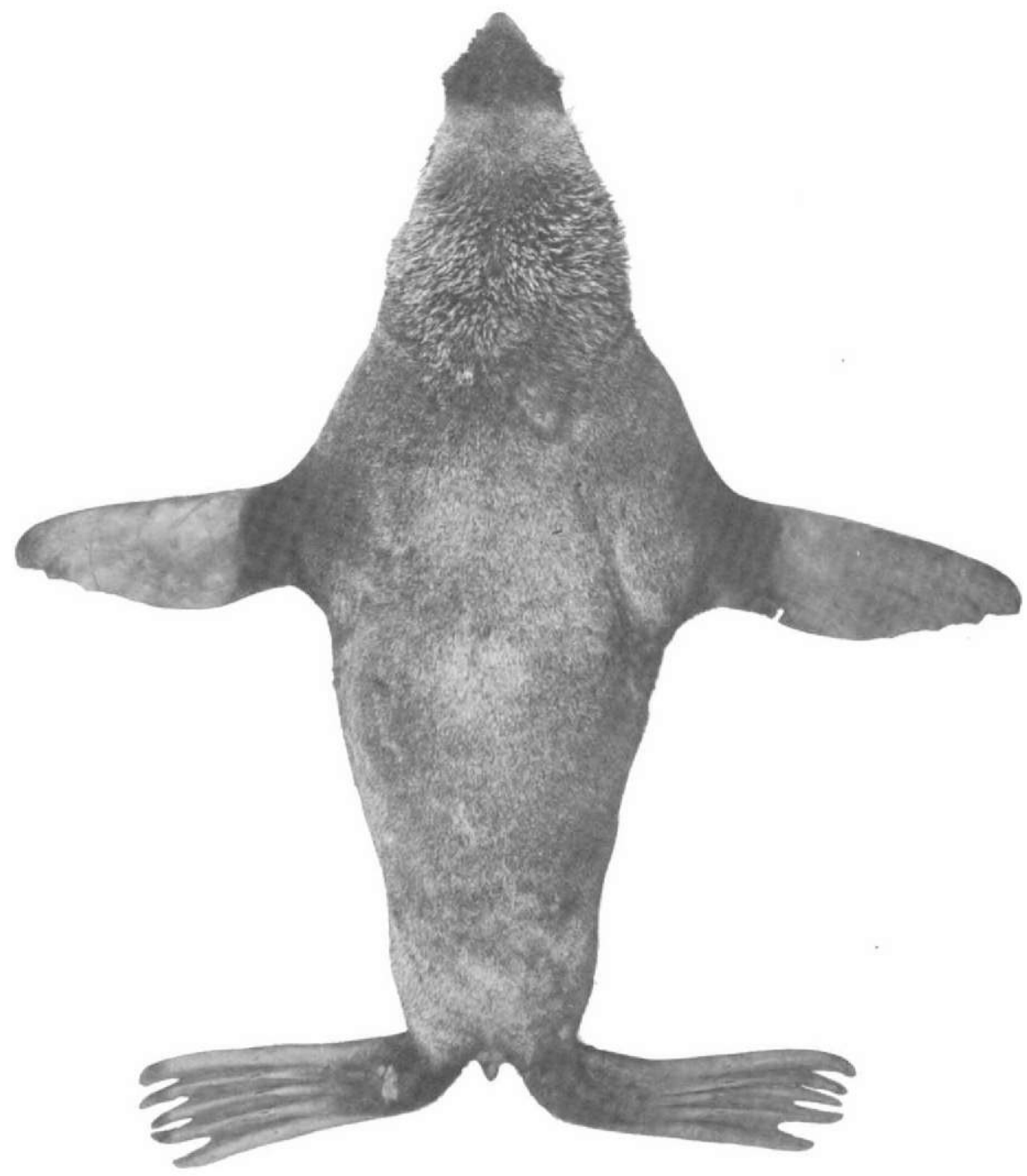

Plate 58.-Fight-year-old male on 2 July; length $191 \mathrm{~cm}$. (75 in.); weight $184 \mathrm{~kg}$. (405 lb.). Note metal tag, applied 8 years previously, on right fore flipper. (2571) 


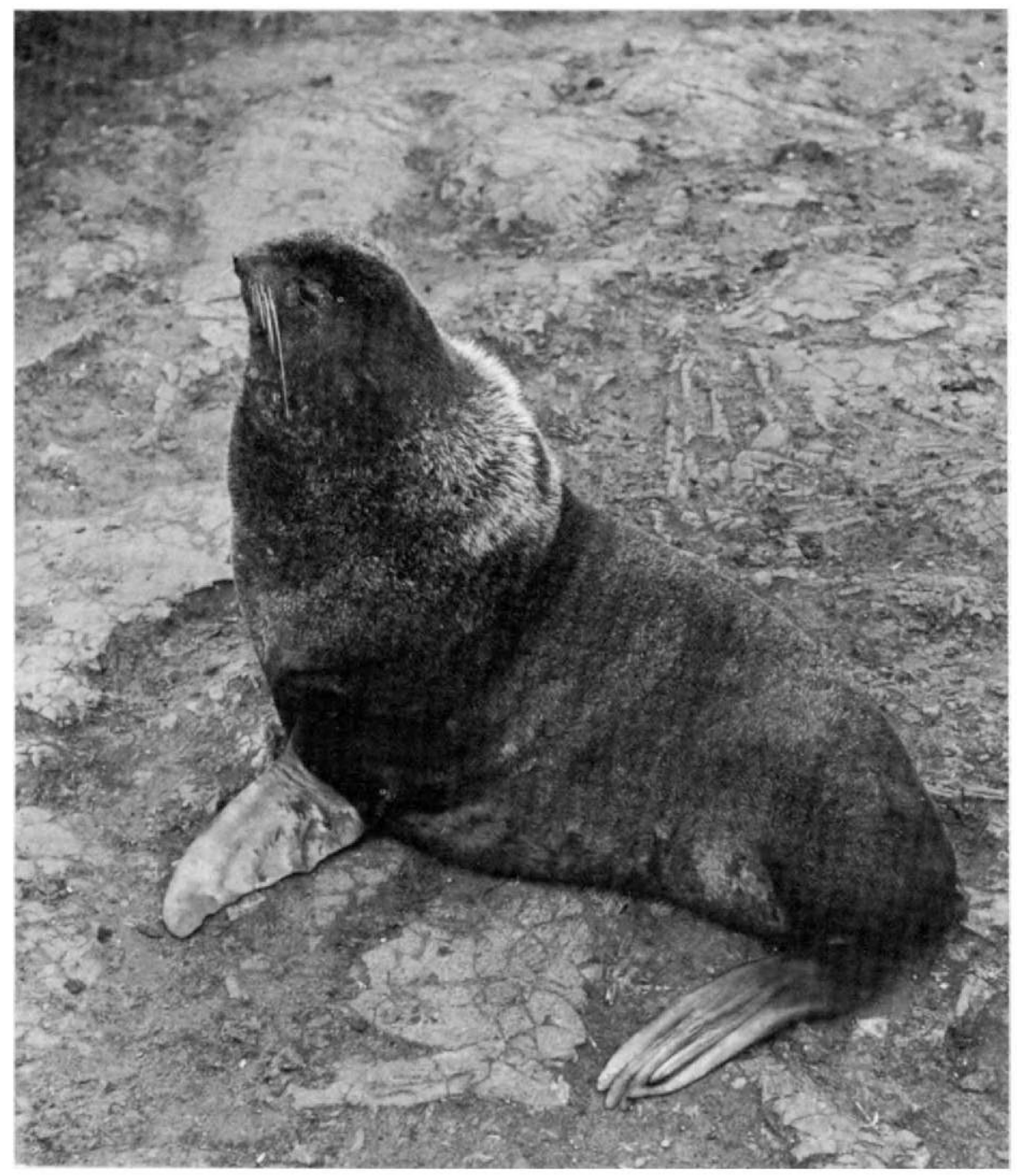

Plate 59.-Nine-year-old male on 27 June; length $196 \mathrm{~cm} .(77 \mathrm{in.})$; weight $188 \mathrm{~kg}$. (415 lb.). Note hot-iron brand, dark spot on lower edge of mane.

(2564) 


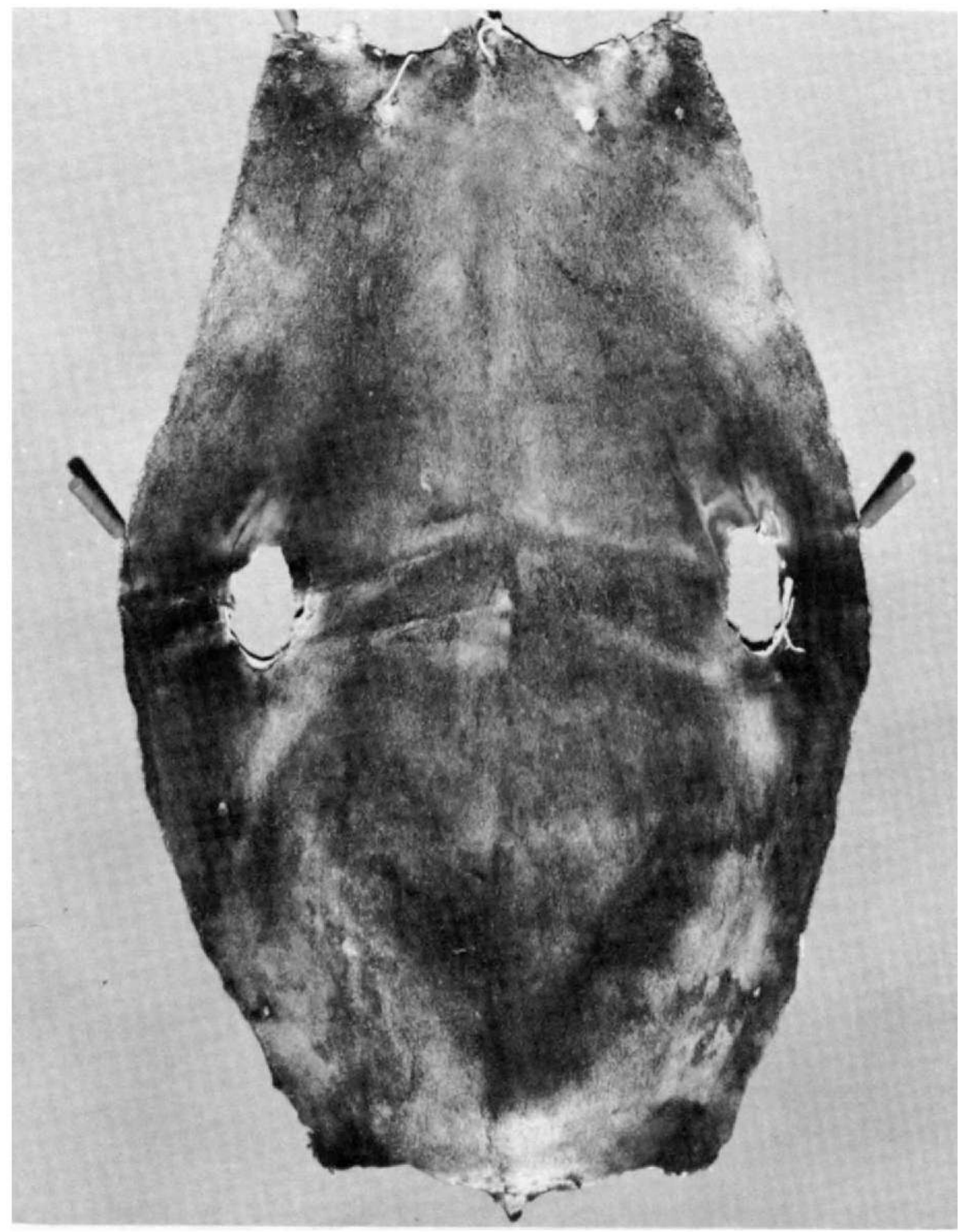

Plate 60.-Tanned pelt of adult female (age $10+$ ) taken on breeding ground on 30 October; in dingy old pelage; $\times 0.14$. Compare plates 61 and 62 .

(4000 USNM 28603F) 


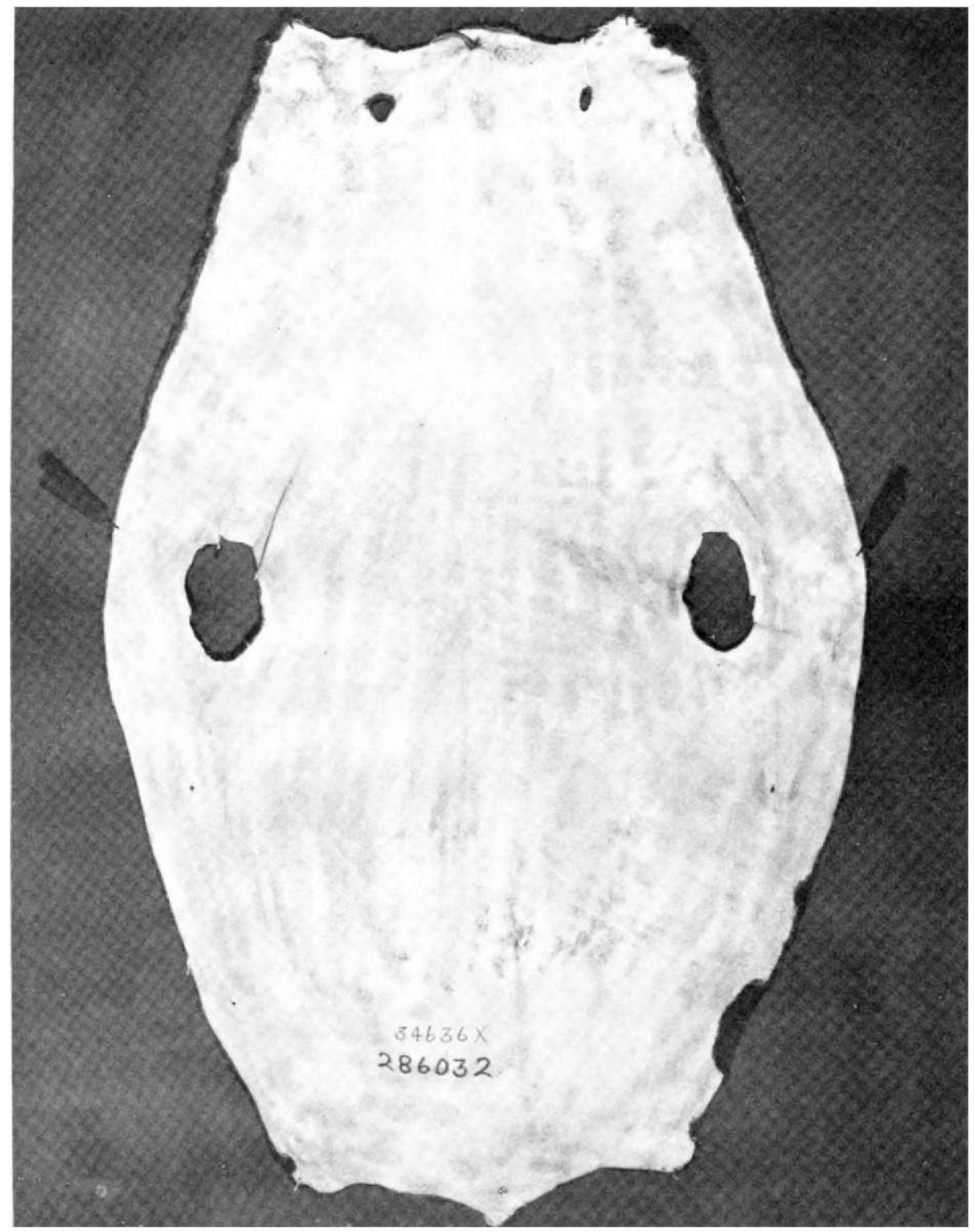

I'LATE 61.-Same nelt as in preceding figure; reverse side showing roots of replacement guard hairs; a typical unprime skin; $\times 0.14$.

(4000 USNM 286032L) 


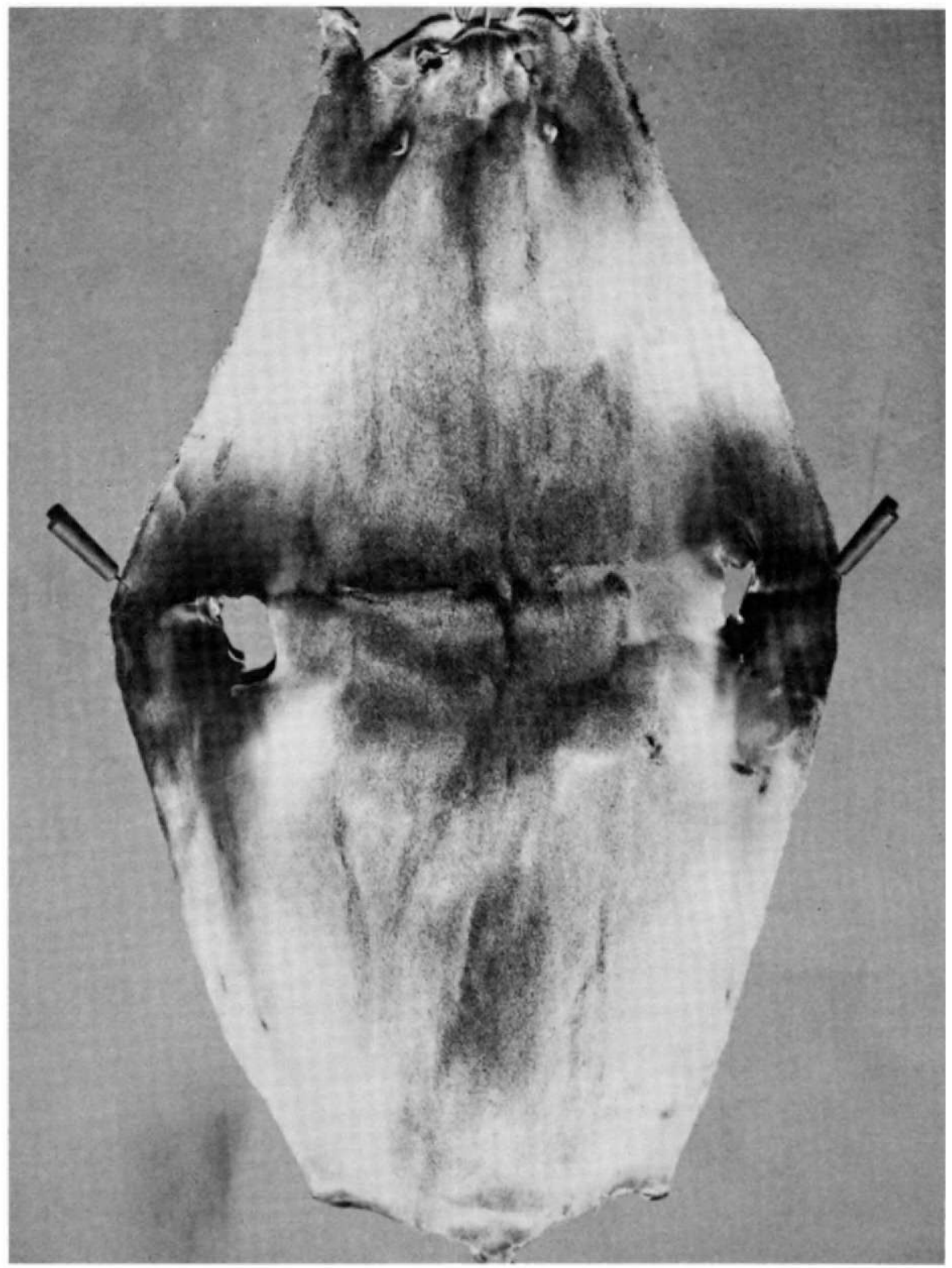

Plate 62.-Tanned pelt of adult female (age 10+) taken at sea on 28 March ; in bright new pelage; $\times 0.14$. Compare plates 60 and 61 .

(4000 SITKA 50-25) 


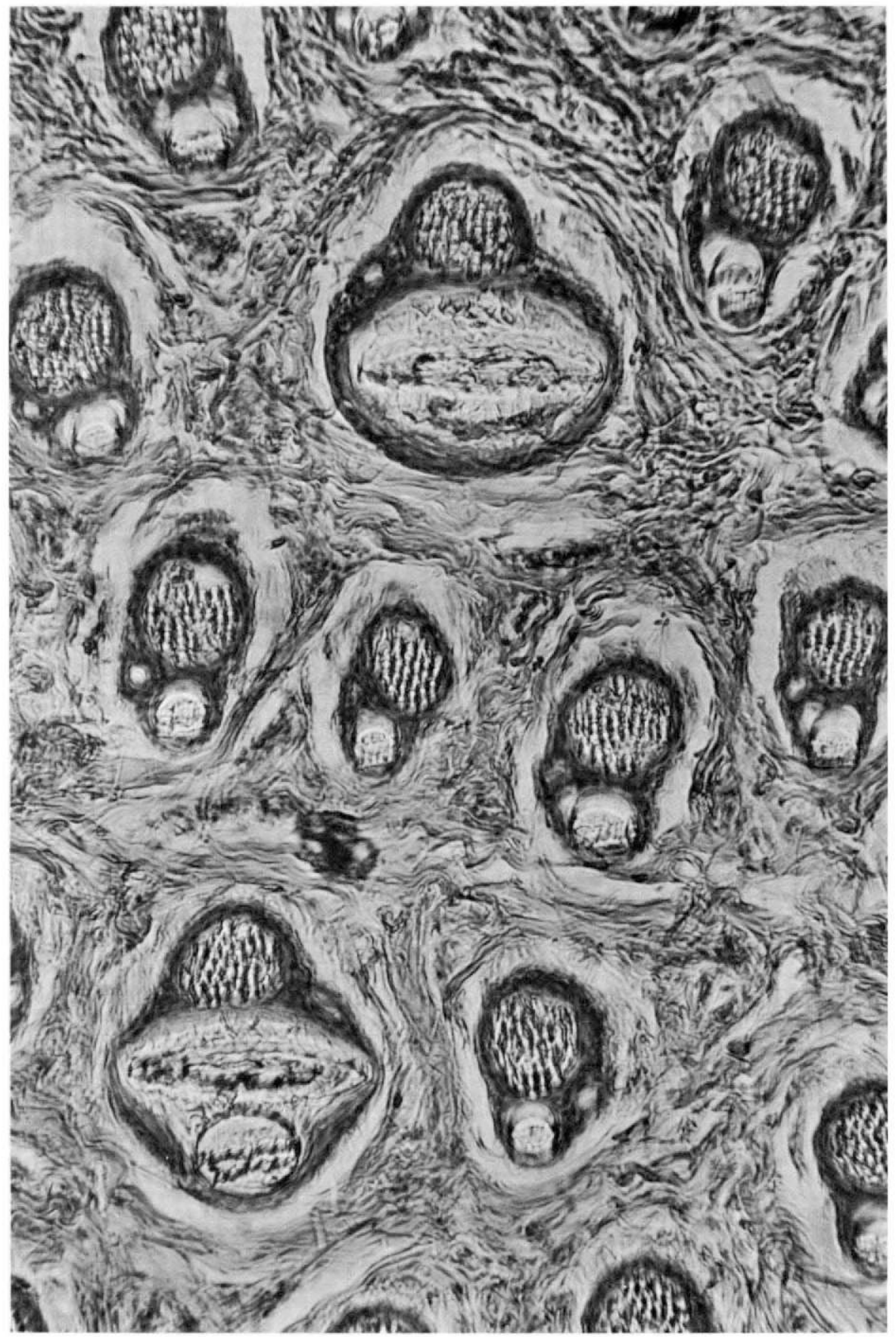

Plate 63.-Horizontal section, at depth of about $0.1 \mathrm{~mm}$., from back of neck of yearling during molt; 26 September; posterior end at top; $\times 200$. In two of the larger follicular bundles the wide blade of a new guard hair is erupting.

(4204) 


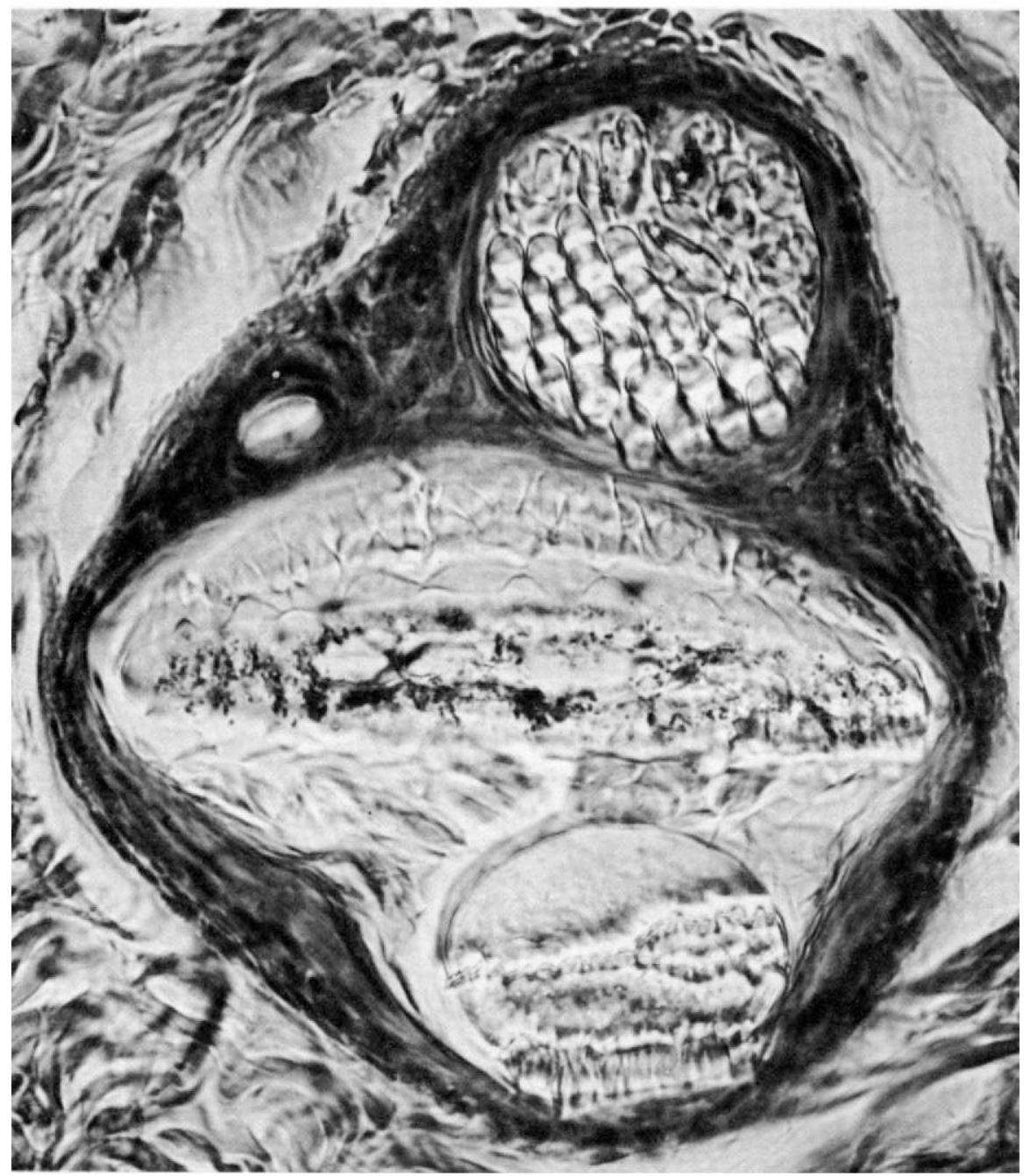

Plate 64.- (See pl. 63.) One follicular bunale; $\times 600$. Note (from top to bottom) bundle of underfur fibers, with newer, strap-shaped fibers above and older, cylindrical fibers below; sweat duct (left); wide, pigmented blade of erupting guard hair; round, translucent root of old guard hair.

(4207) 


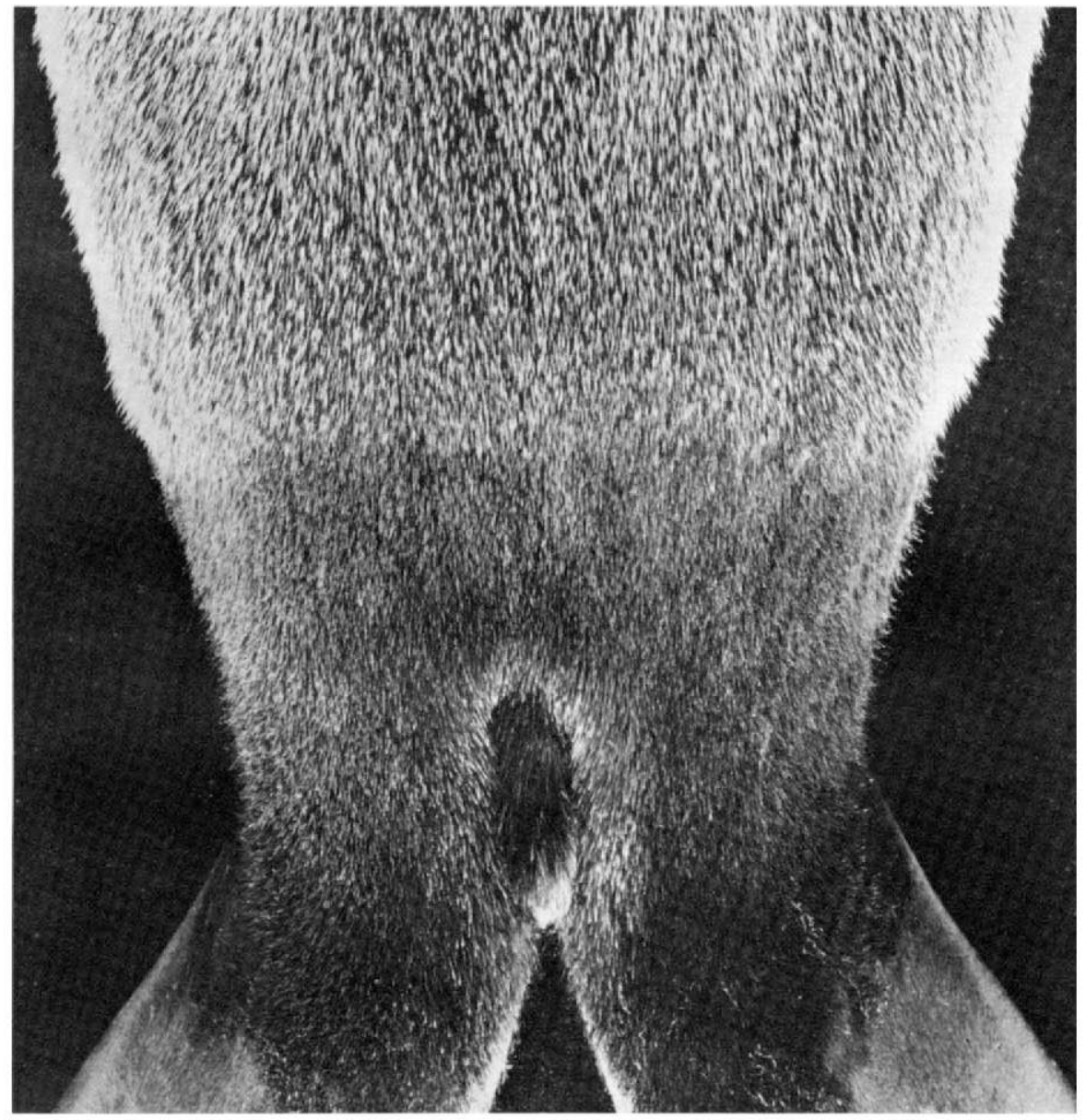

Plate 65.-Molt line on rump of yearling, autumn; female; 3 October; $\times 0.7$. Second adult-type pelage is progressing toward rear (toward bottom of figure). (4070) 


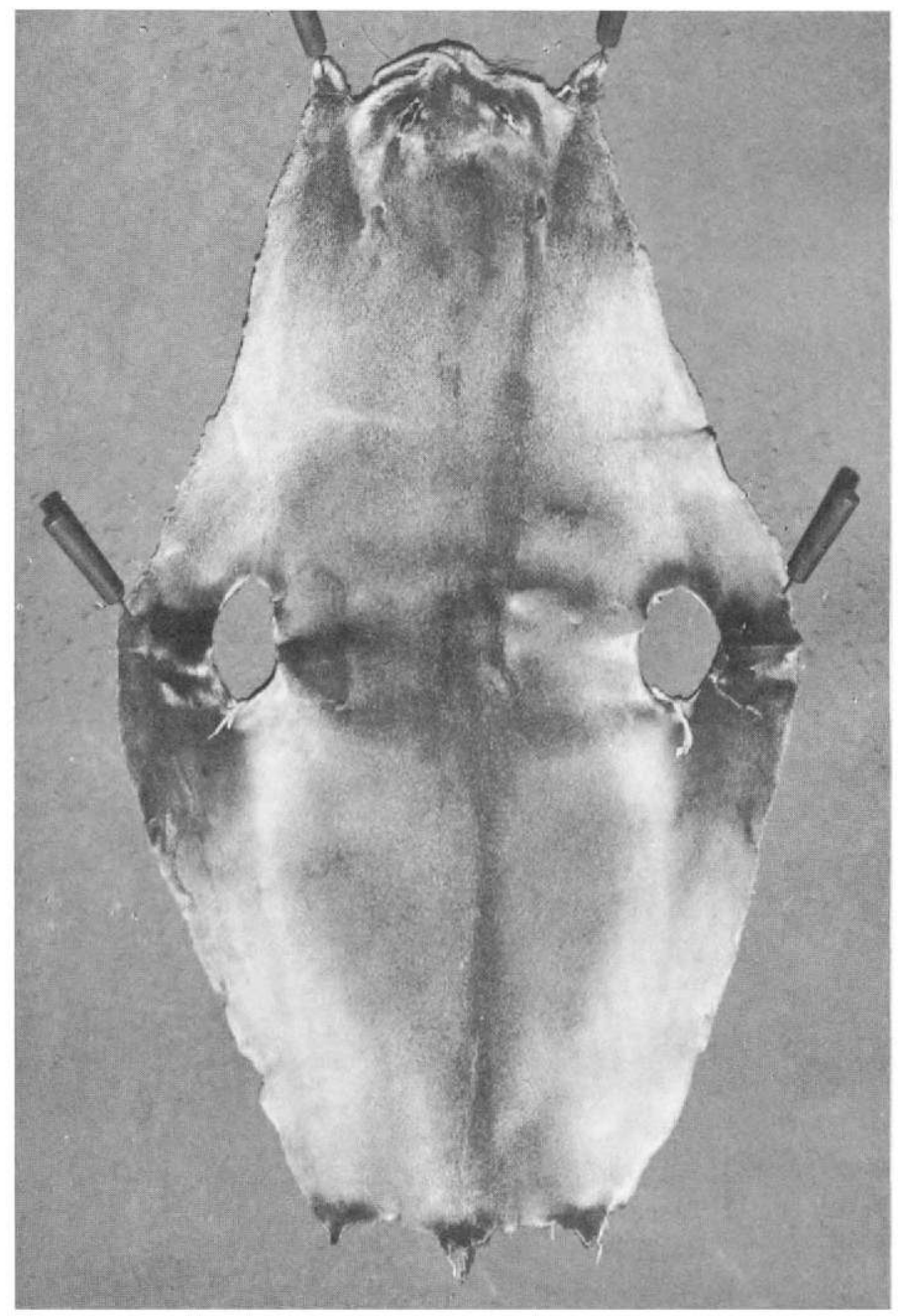

Plate 66.-Tanned pelt of 2-year-old female; 21 September; in third molt; pelage short and lacklustre; $\times 0.2$.

(4000 BDM 239) 


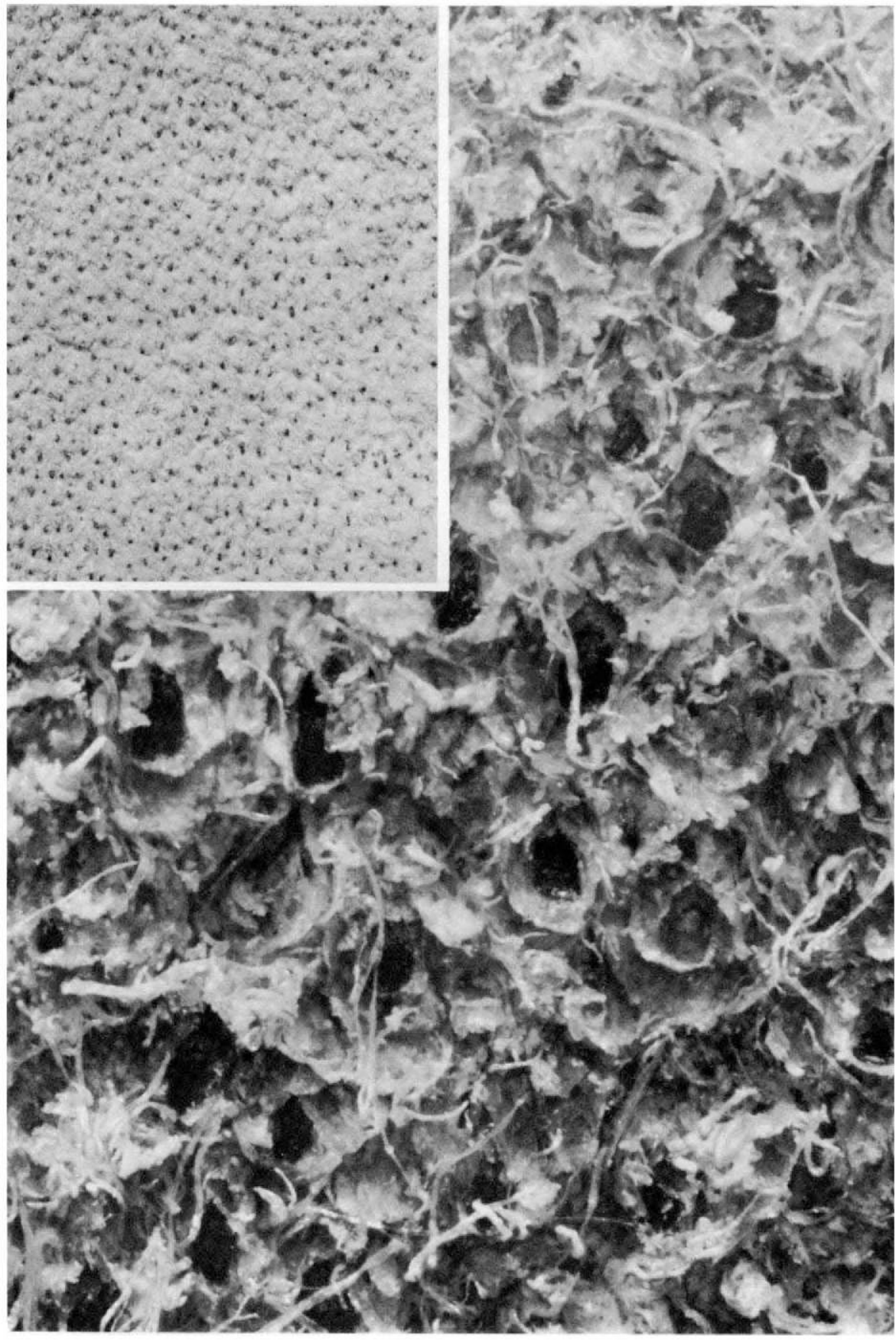

Plate 67.-Reverse side of unprime pelt which was shown in plate 66 ; anterior end toward bottom of photo; $\times 40$. Note black stumps of replacement guard hairs, cut off on 21 September before they had reached the surface. Insert is $\times 4$. 


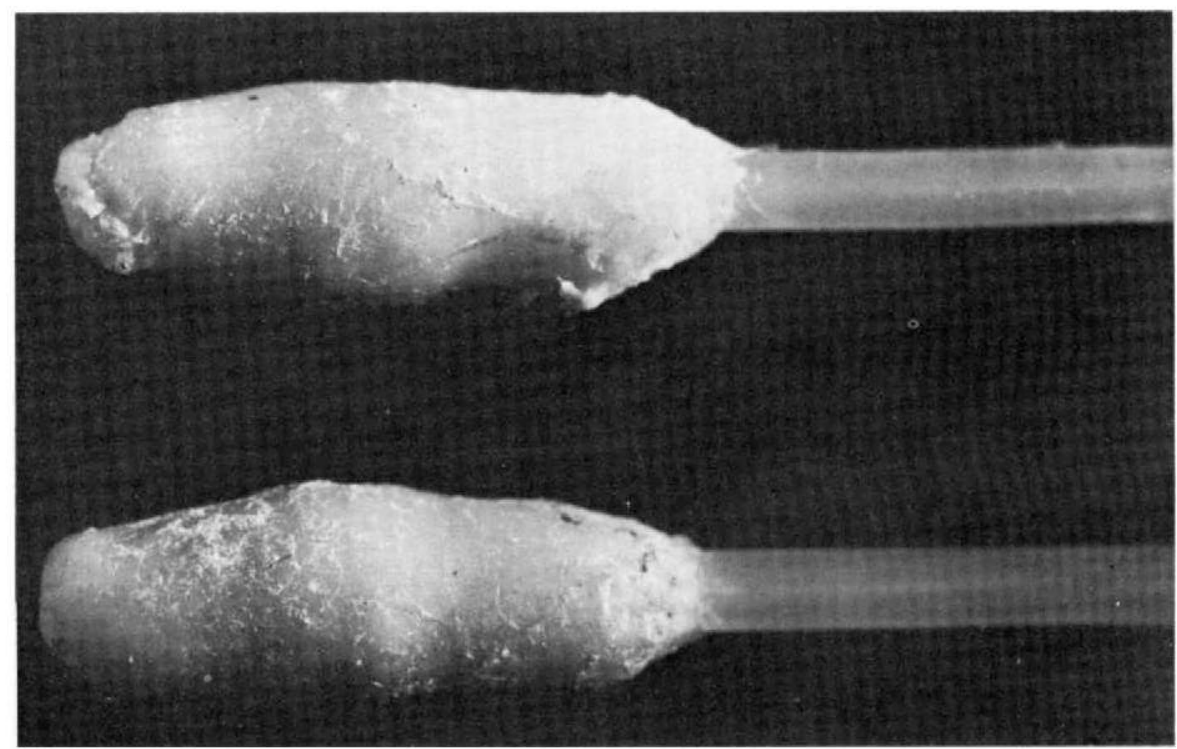

Plate 68-A.-Two mystacial vibrissae from 6-year-old female, showing massive connective-tissue sheath around root; specimen cleaned by marine amphipods; $\times 6$.

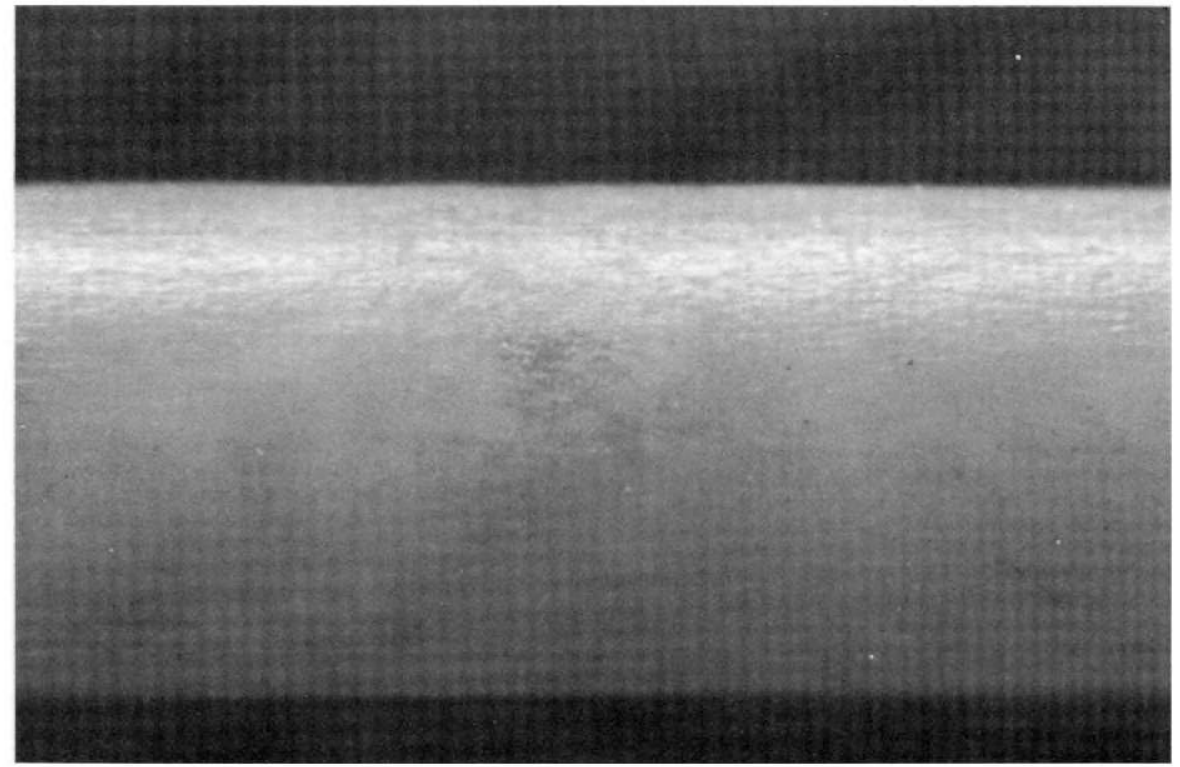

Plate 68-B.-Vibrissa of 10-year-old male showing smooth surface; $\times 50 . \quad(3951)$ 


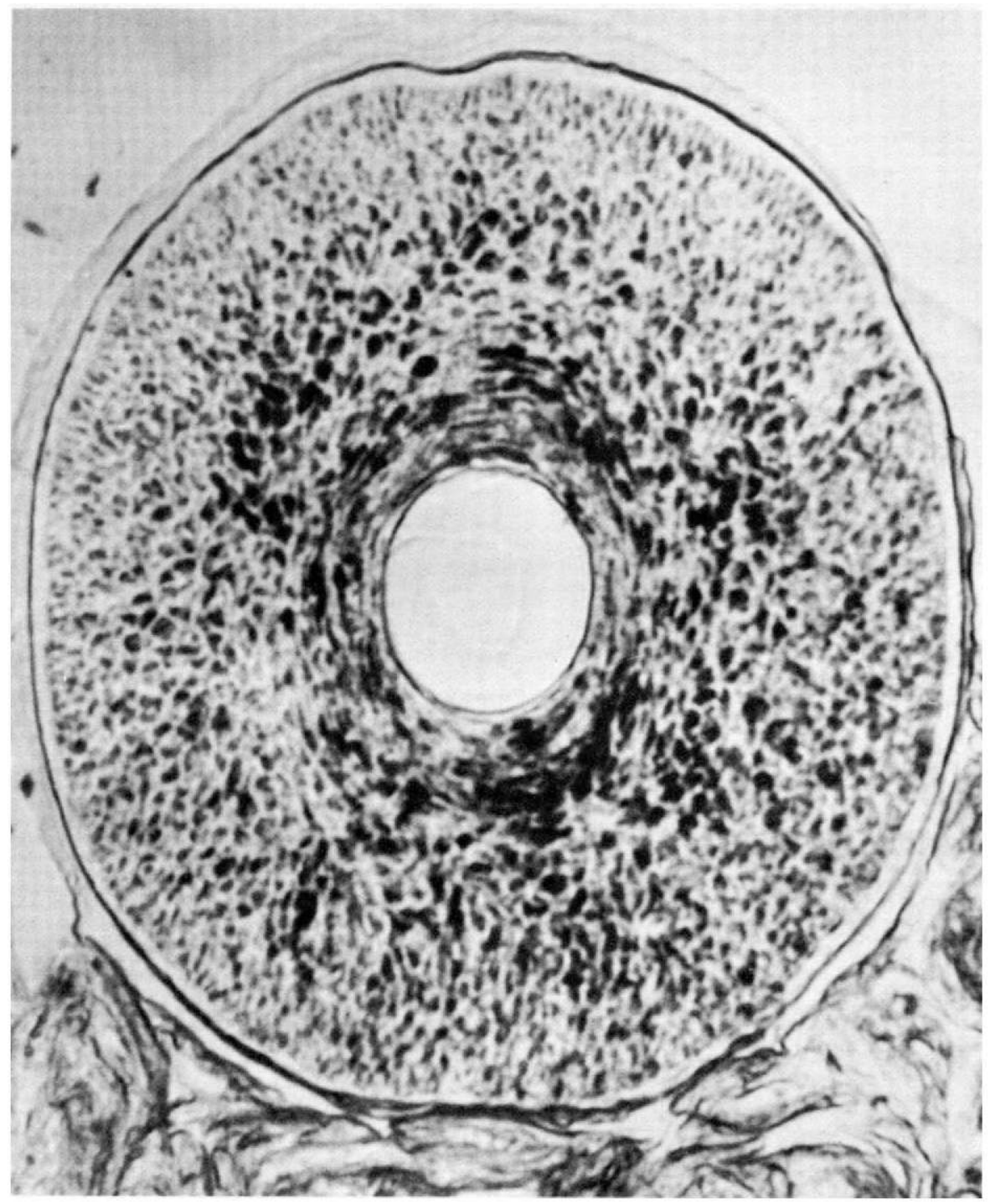

Plate 69.-Cross section of vibrissa of black pup (full-term fetus) showing: open medulla; broad cortex, pigmented except for narrow peripheral band; thin cuticle appearing dark under this illumination; $\times \mathbf{4 0 0}$.

(4157) 


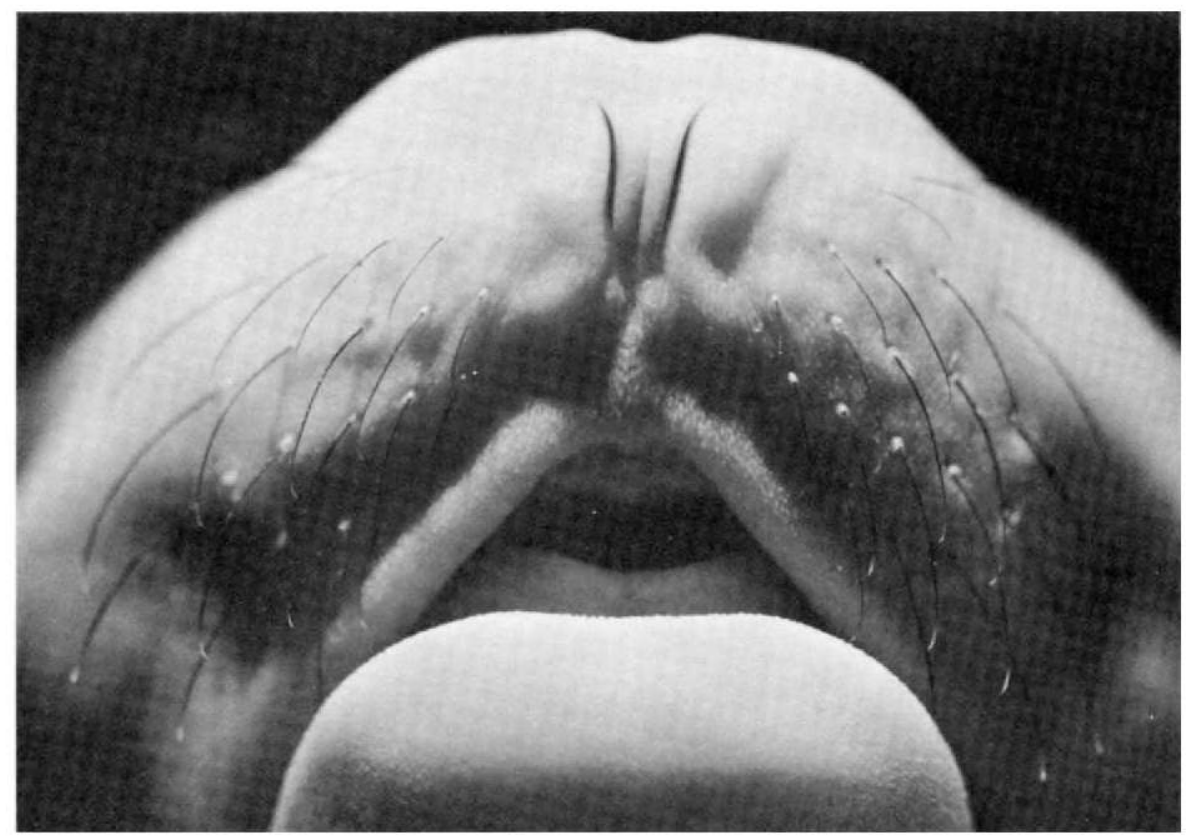

Plate 70-A,-Face of $103 \mathrm{~g}$. fetus with full set of 20 mystacial vibrissae; $\times 6$.

(4126)

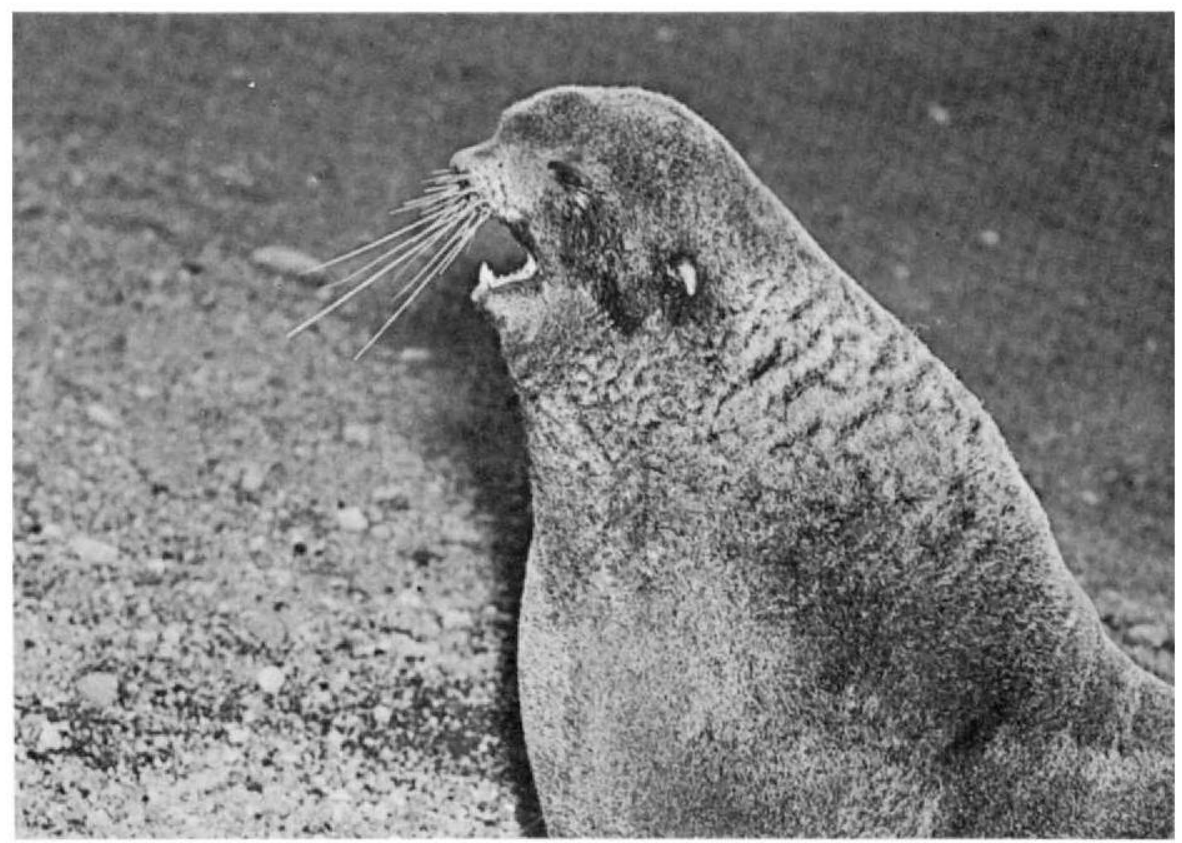

PLate 70-B.--Vibrissae of adult male turned outward and forward in threat reaction during breeding season; 15 July; vibrissae white at this age.

(2647) 


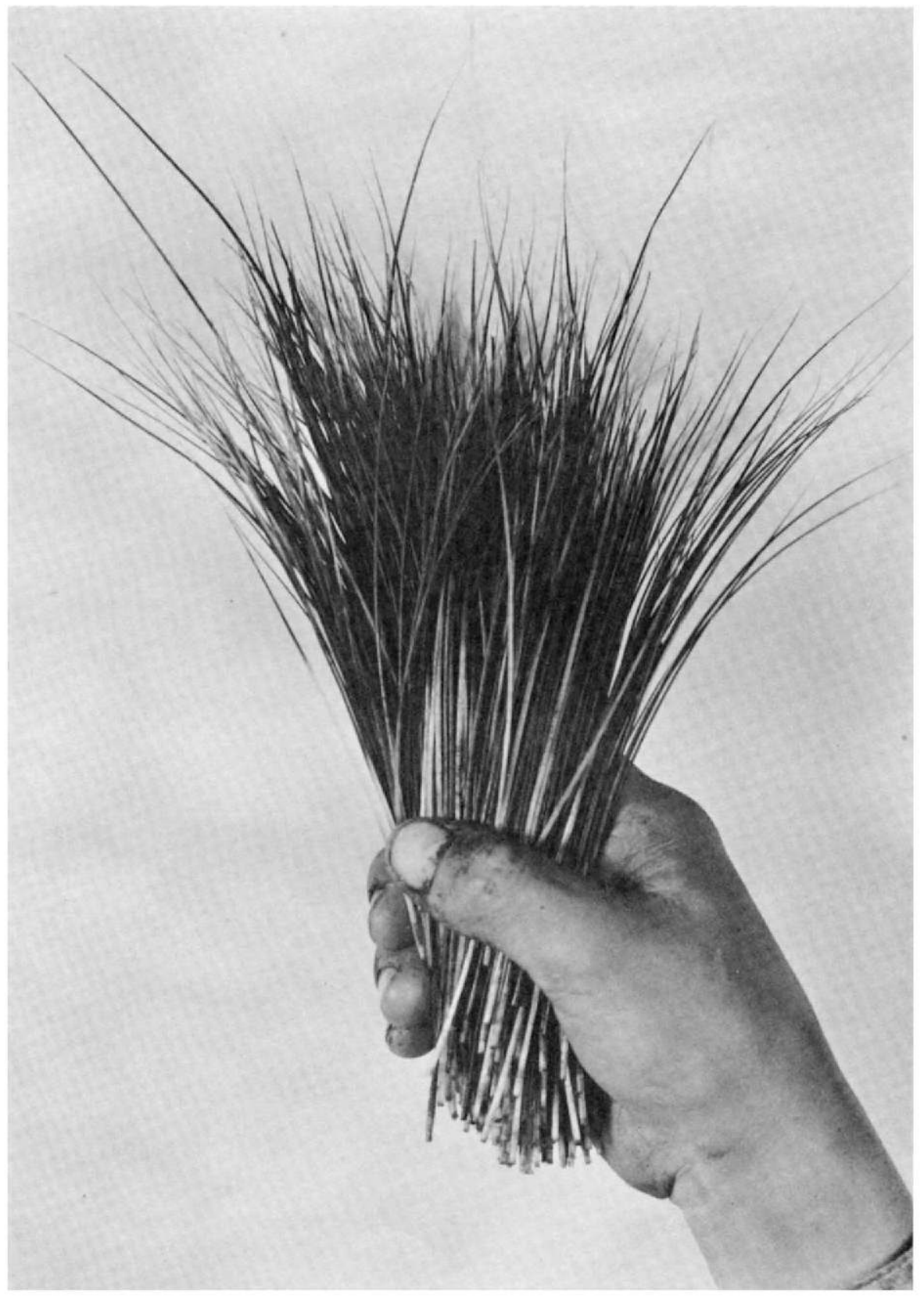

Plate 71.-Vibrissae of subadult males, ages 3 and 4 years, plucked on killing field by small boy. In these year-classes the vibrissae are beginning to turn white at base, and to present a mottled appearance.

(2221) 


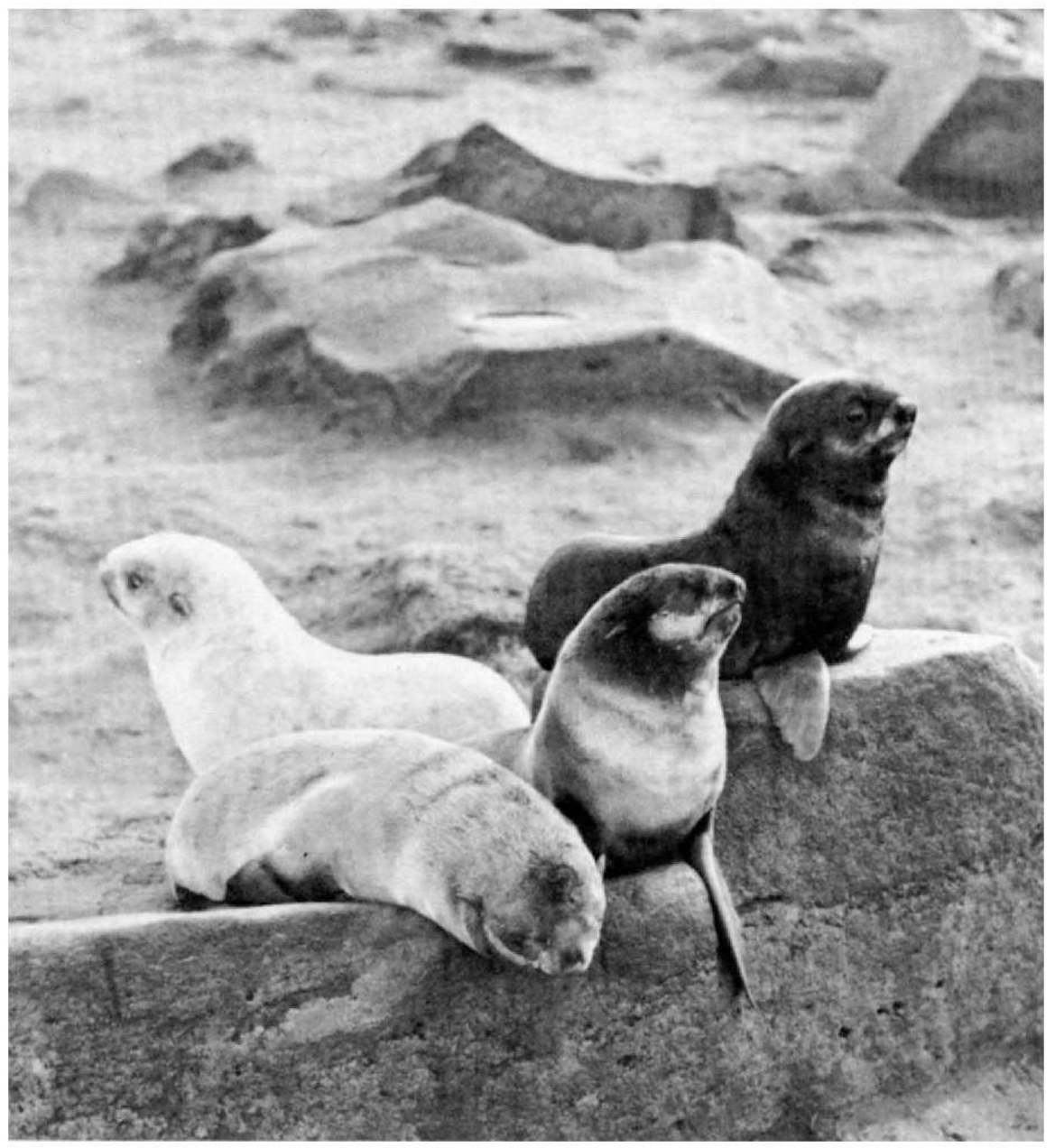

Plate 72.-Four pelage phases of the pup on 11 October (reading clockwise) : pup born late in summer and termed "black pup, molting"; pup in first adult-type pelage termed "silver pup"; and two freaks termed "chocolate" and "albino," respectively. 


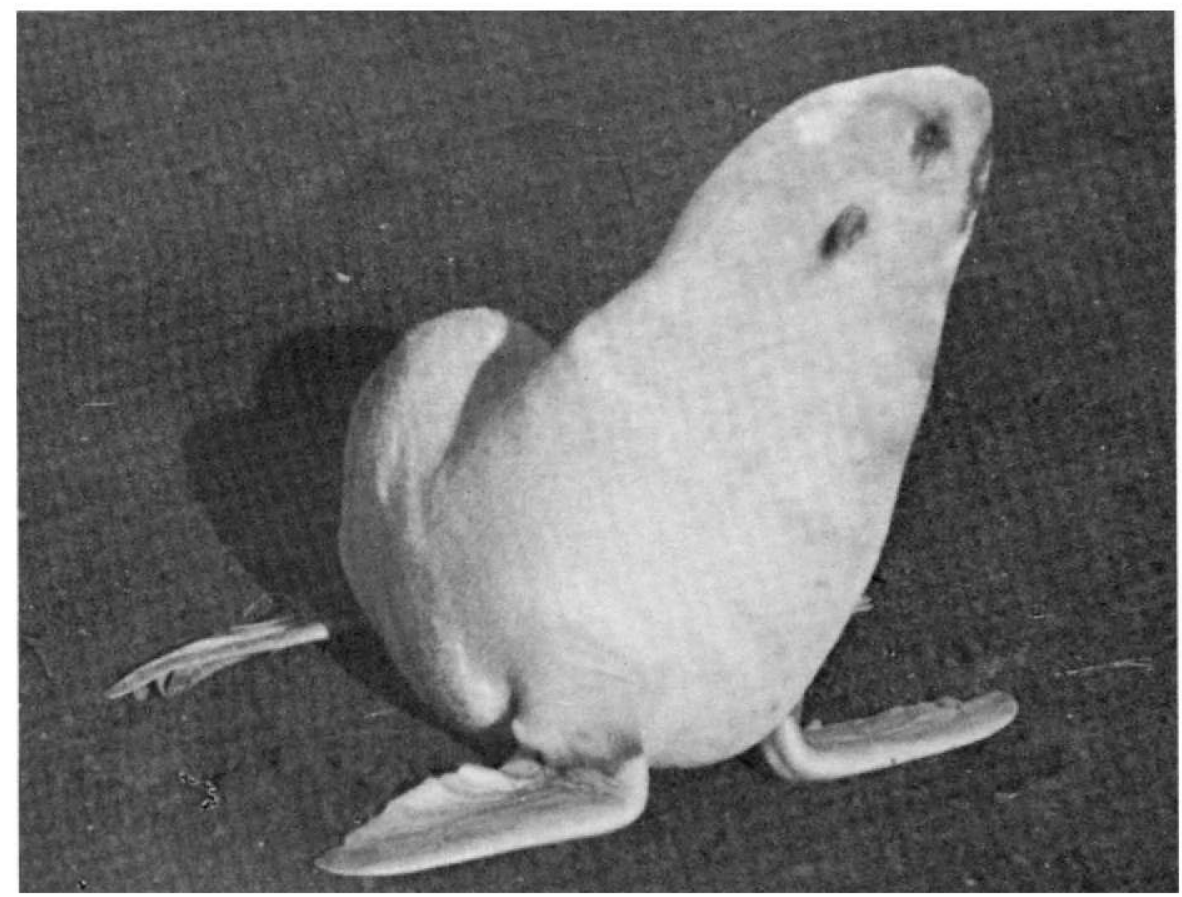

Plate 73-A.-Albino pup in flrst adult-type pelage, corresponding to "silver" pelage of normal pup in autumn; male; 10 October.

(2321)

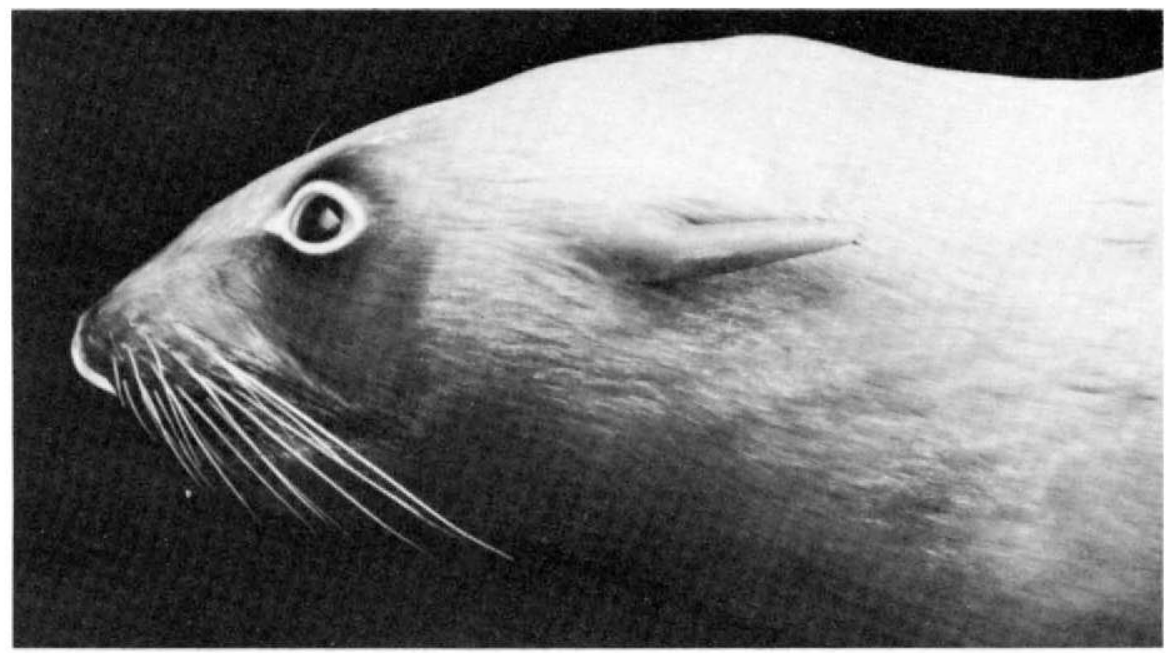

Plate 73-B.--Head of female albino pup; Seattle Z0o; 2 December; dark areas are stained.

(4131) 


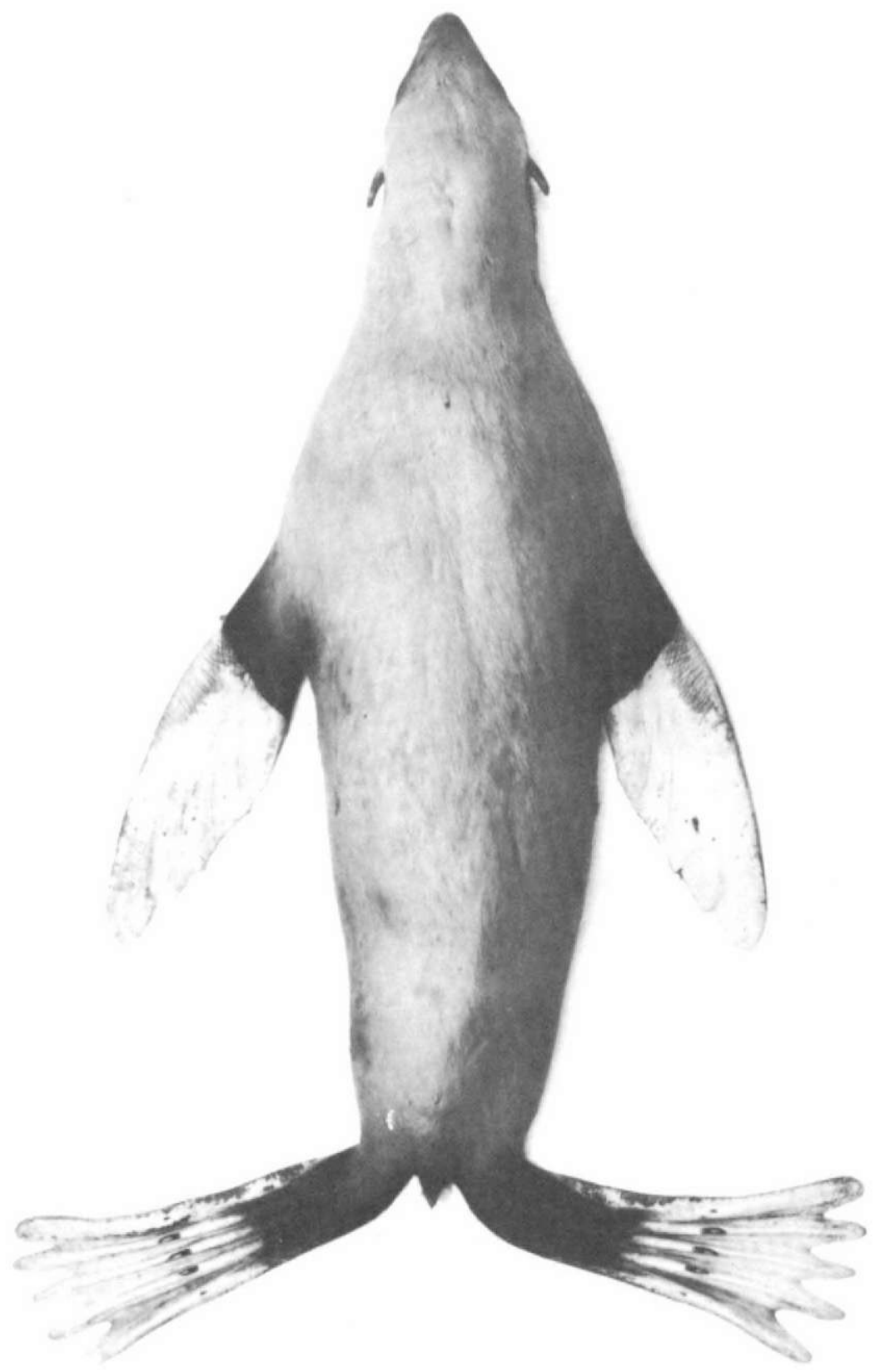

Plate 74.-Albino adult female collected on rookery, 15 August, in stained coat which she had been wearing for about 10 months.

(2871) 


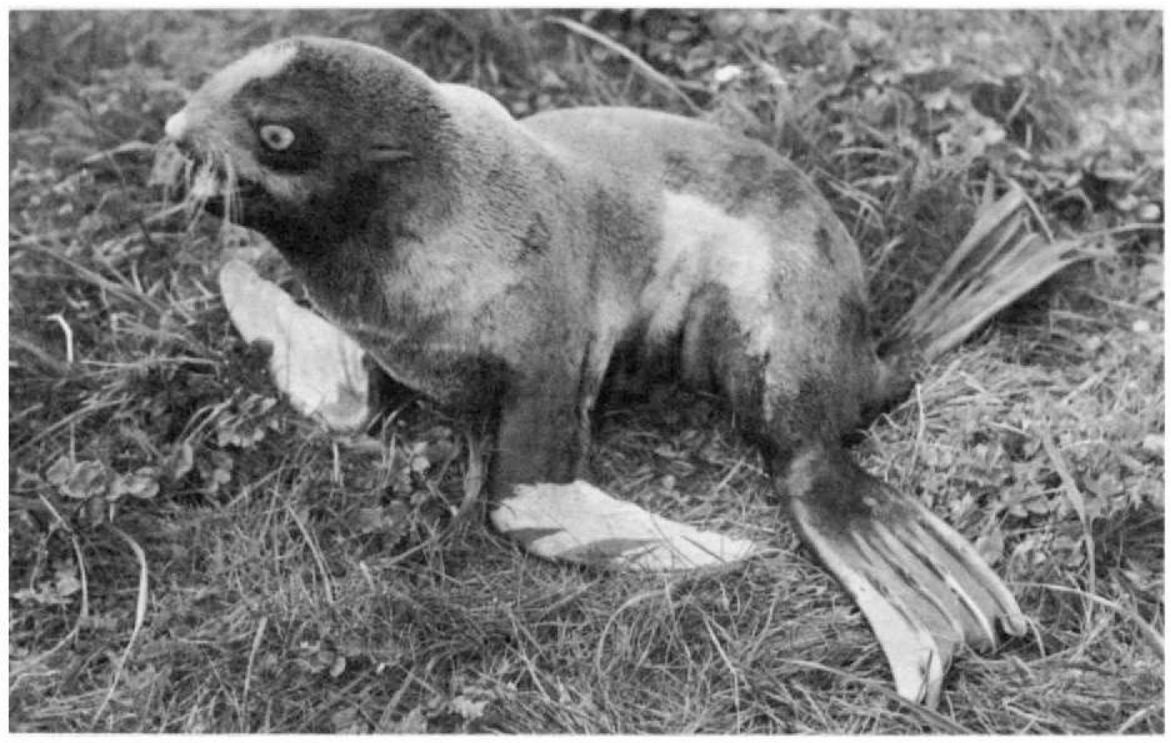

Plate 75-A.-Piebald subadult male; 8 August.

(1044)

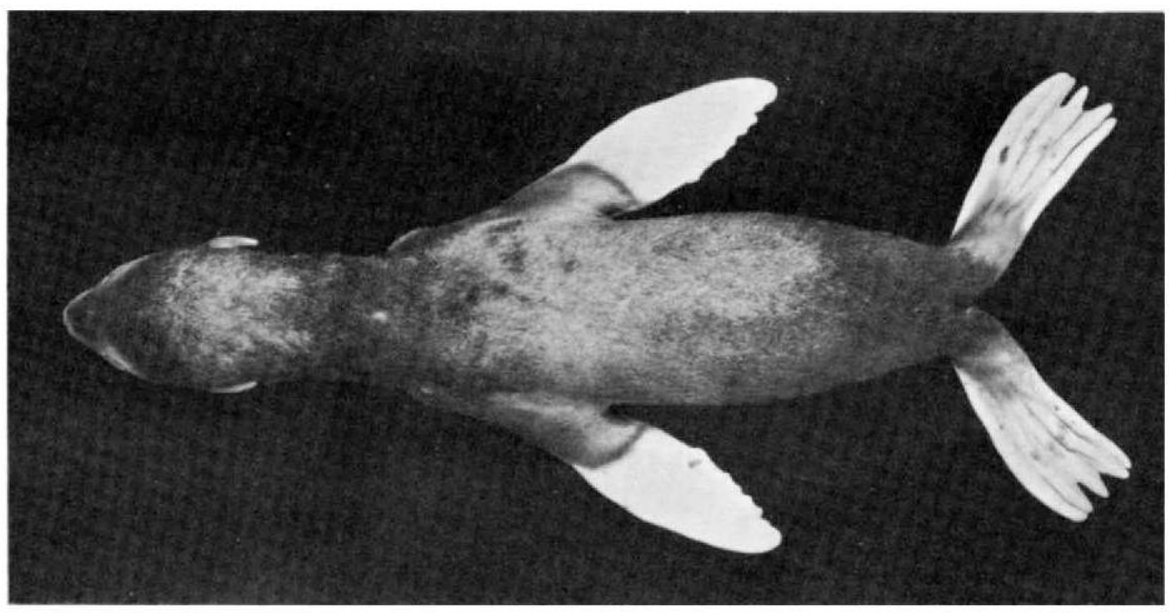

Plate 75-B.--Partial albino pup in birthcoat (molting) ; 11 August; eyes and flippers pinkish white; underhair white; guard hair grayish brown.

(2436) 


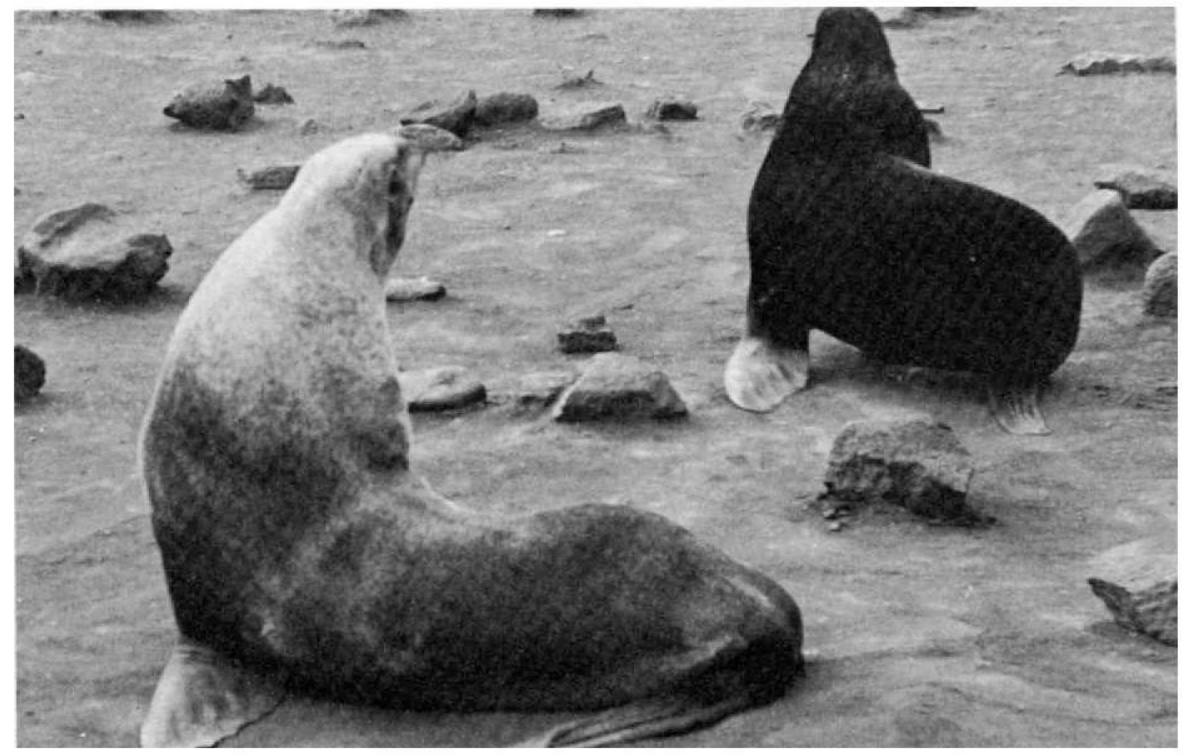

PLATe 76-A.-Two adult bulls, exemplifying range in pelage color from light to dark; 22 July.

(2056)

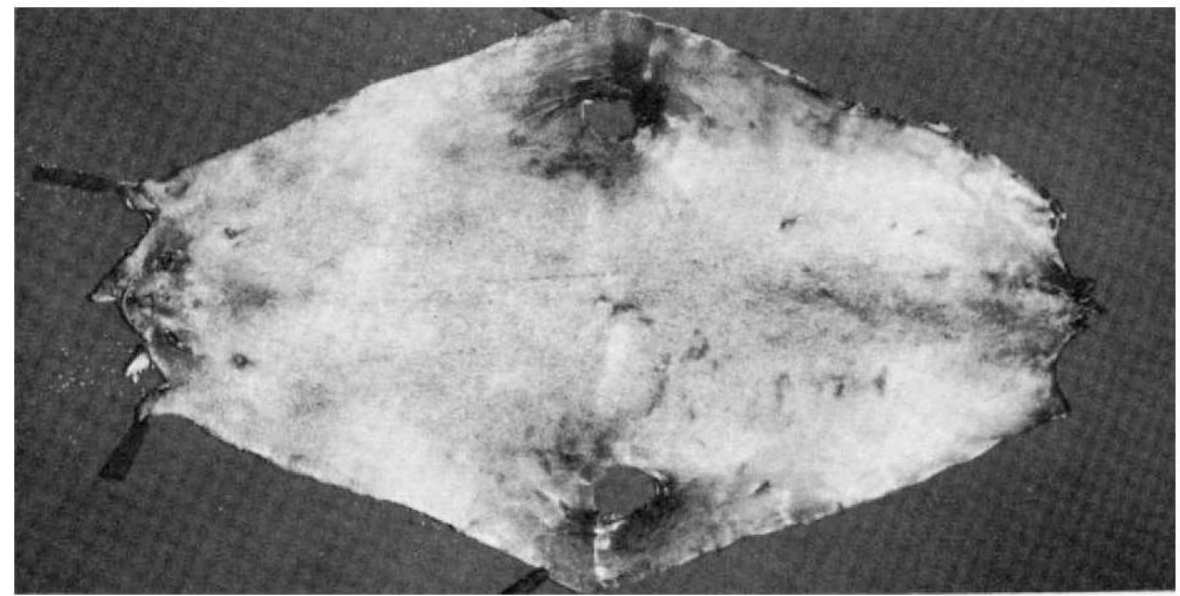

Plate 76-B.-Pelt of subadult male; pale phase; 5 August.

(4000 BDM 350) 


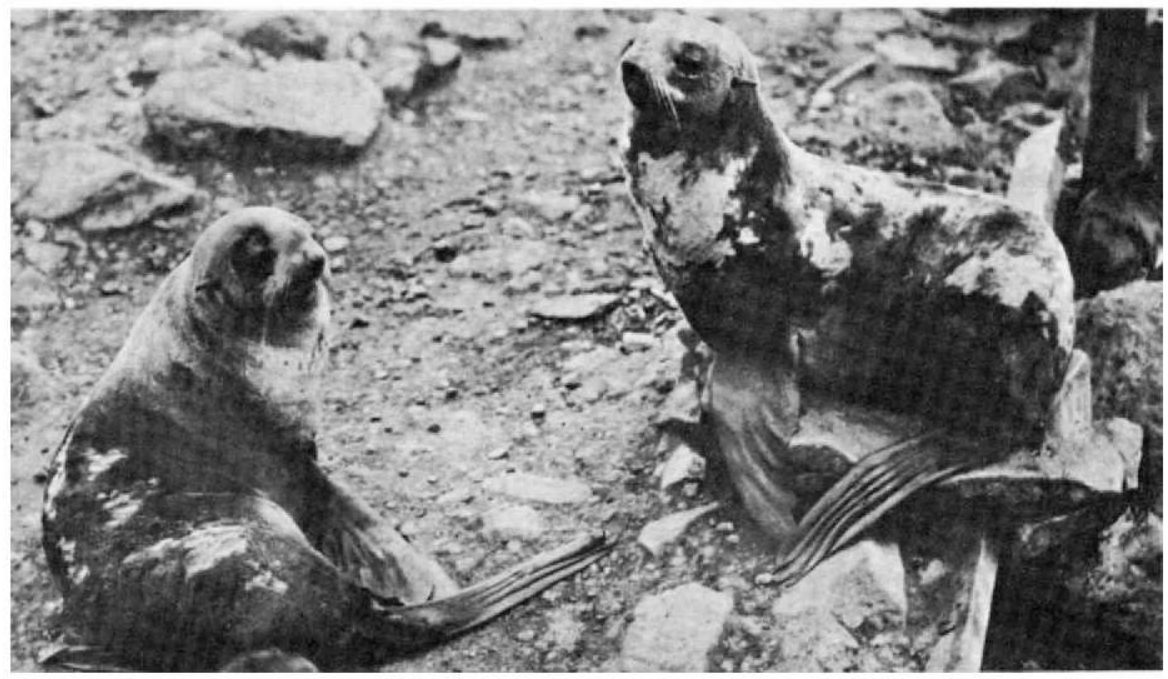

Plate 77-A.-Adult cows with blotchy or "rubbed" pelage; guard hair absent in patches; 23 July.

(1004)

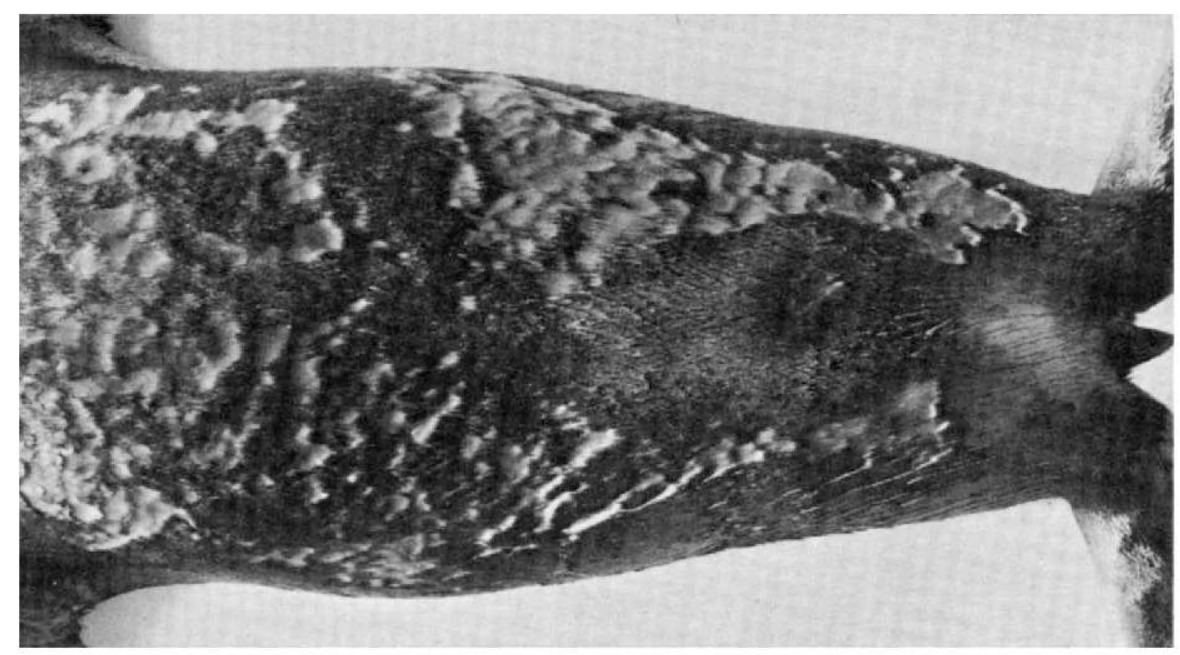

Plate 77-B.-Similar; body of 6-year-old cow; washed and nearly dried; 12 September; dorsal view.

(4031) 


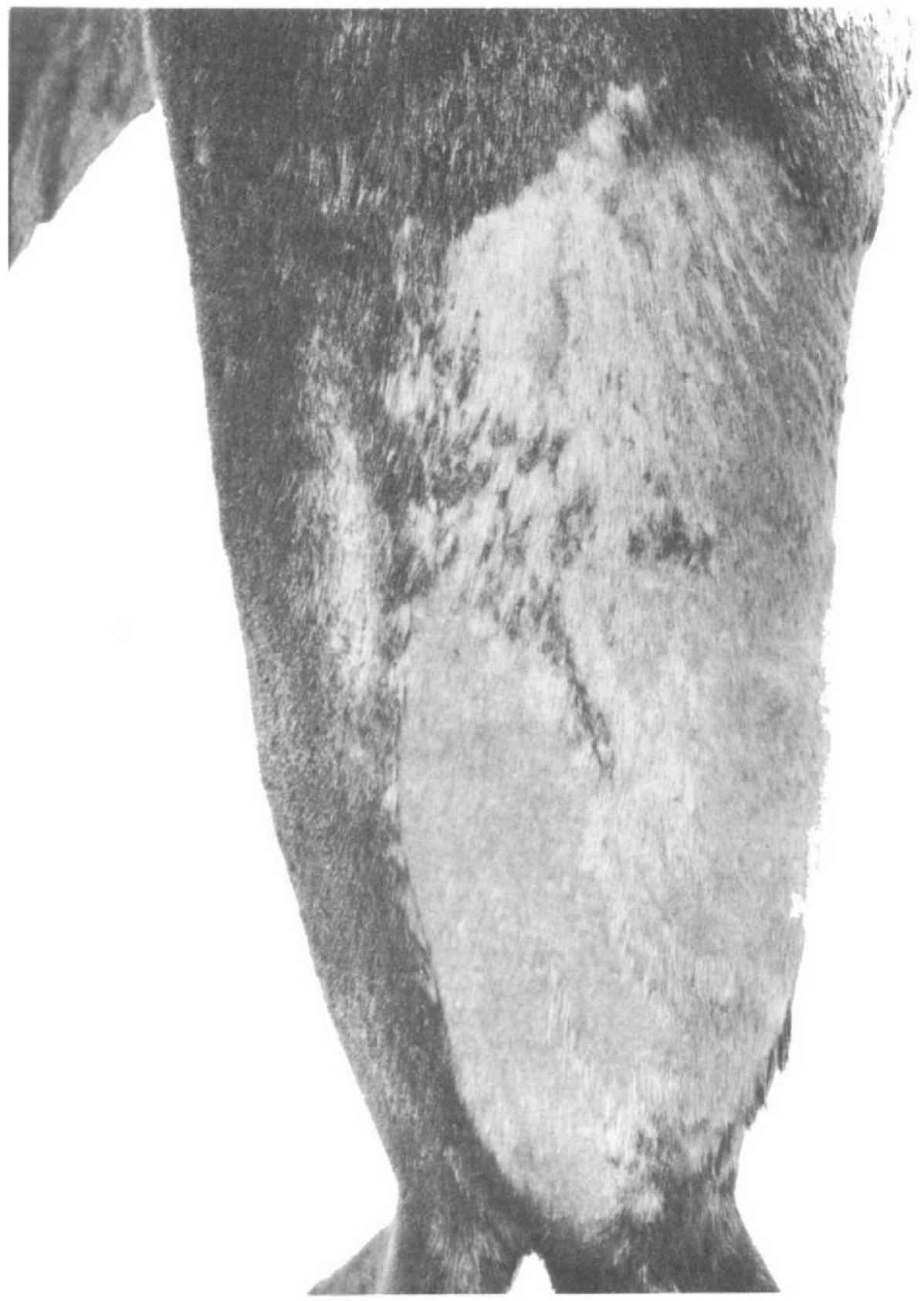

PLATE 78.--Body of subadult male with "rubbed" back; 26 July. 


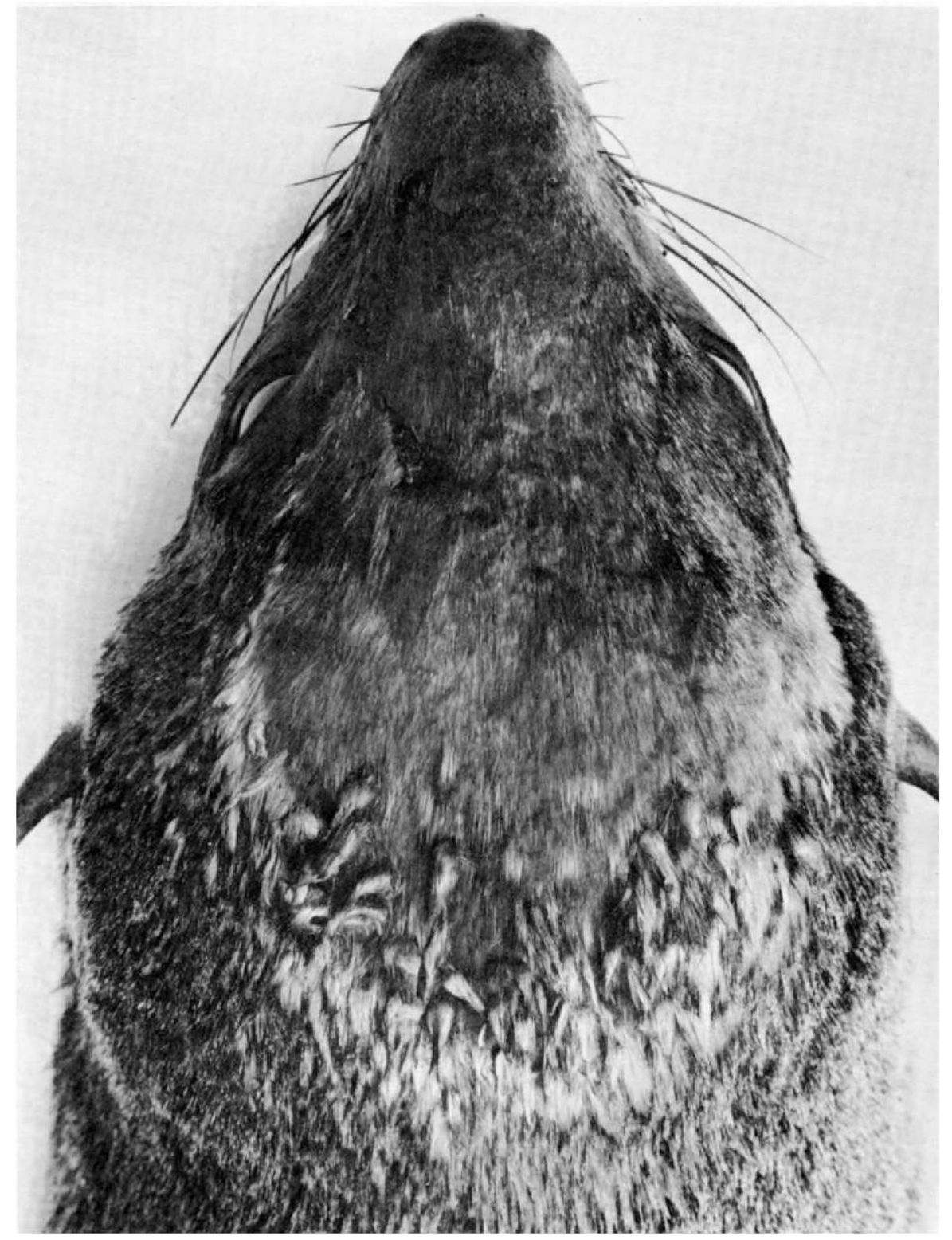

Plate 79.--Top of head of subadult male shown in preceding plate.

(1872) 


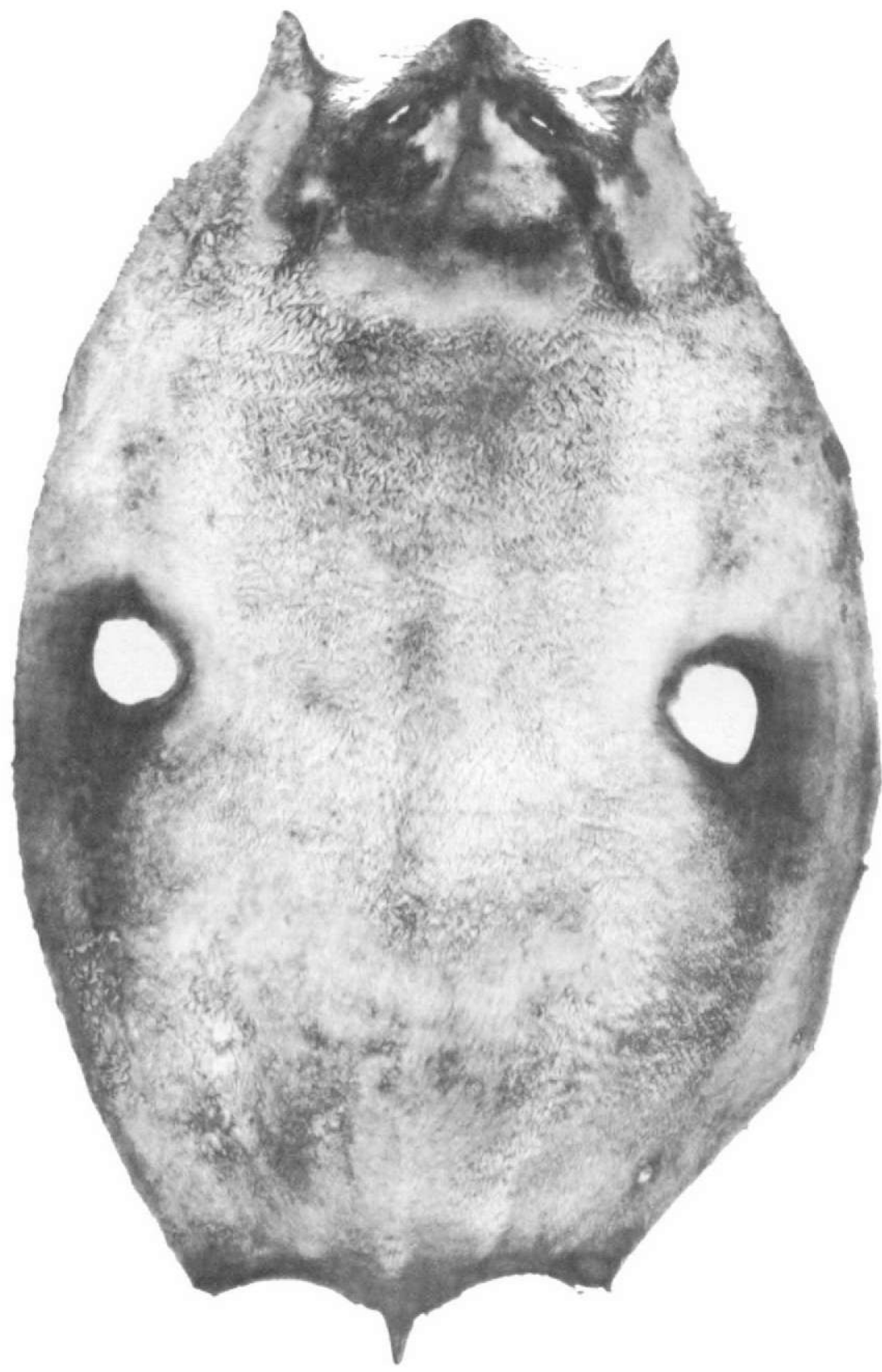

Plate 80.-Fresh, damp pelt of 2-year-old female lacking most of guard hair; guard hair present only in patches on face and on bases of flippers; 2 July.

(2821) 


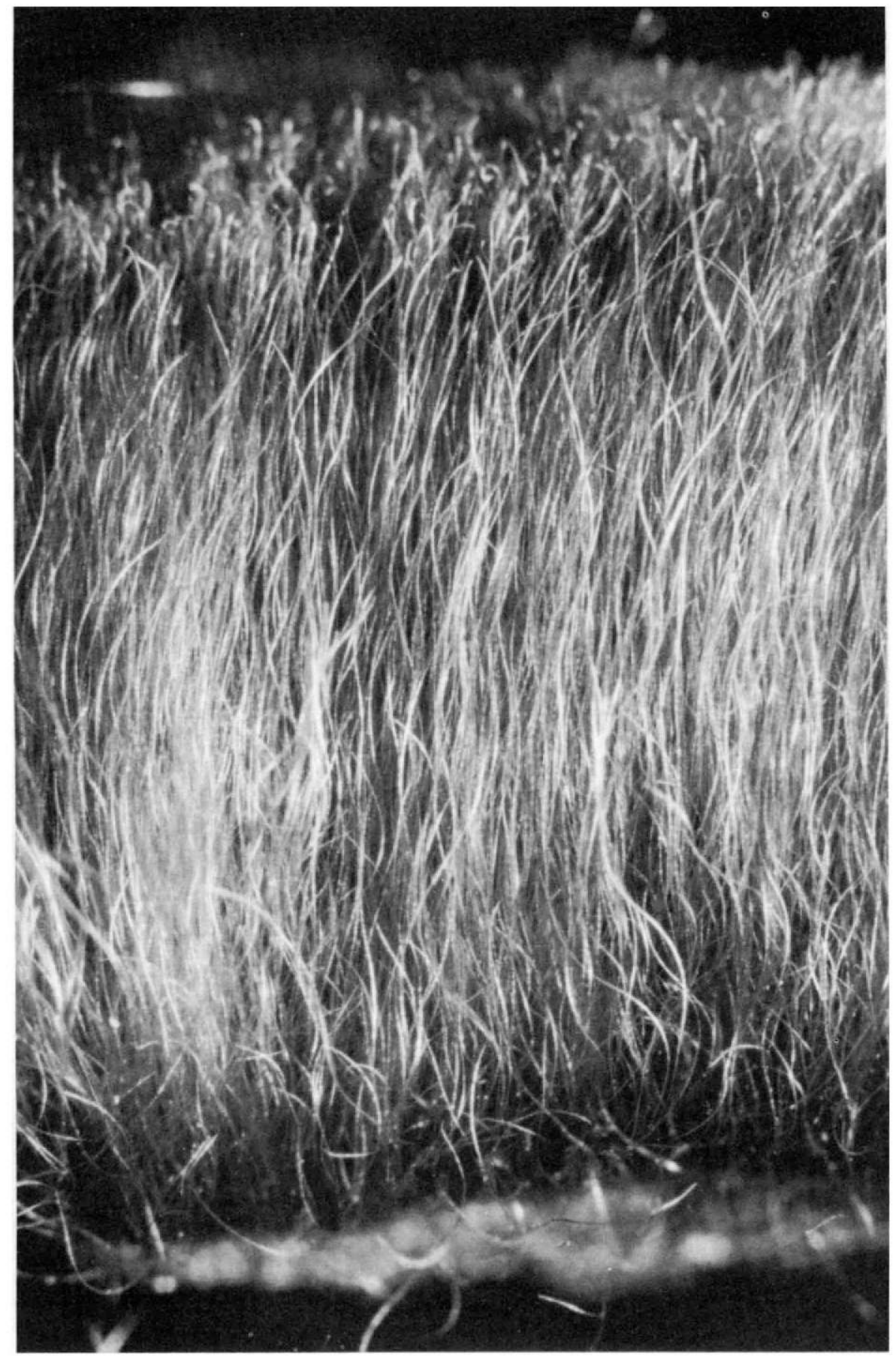

Plate 81.-Tuft of fur from "rubbed" area on back of subadult male, showing absence of guard hairs but fairly normal appearance of underfur fibers; 27 July; posteroventral view : $\times 15$. 


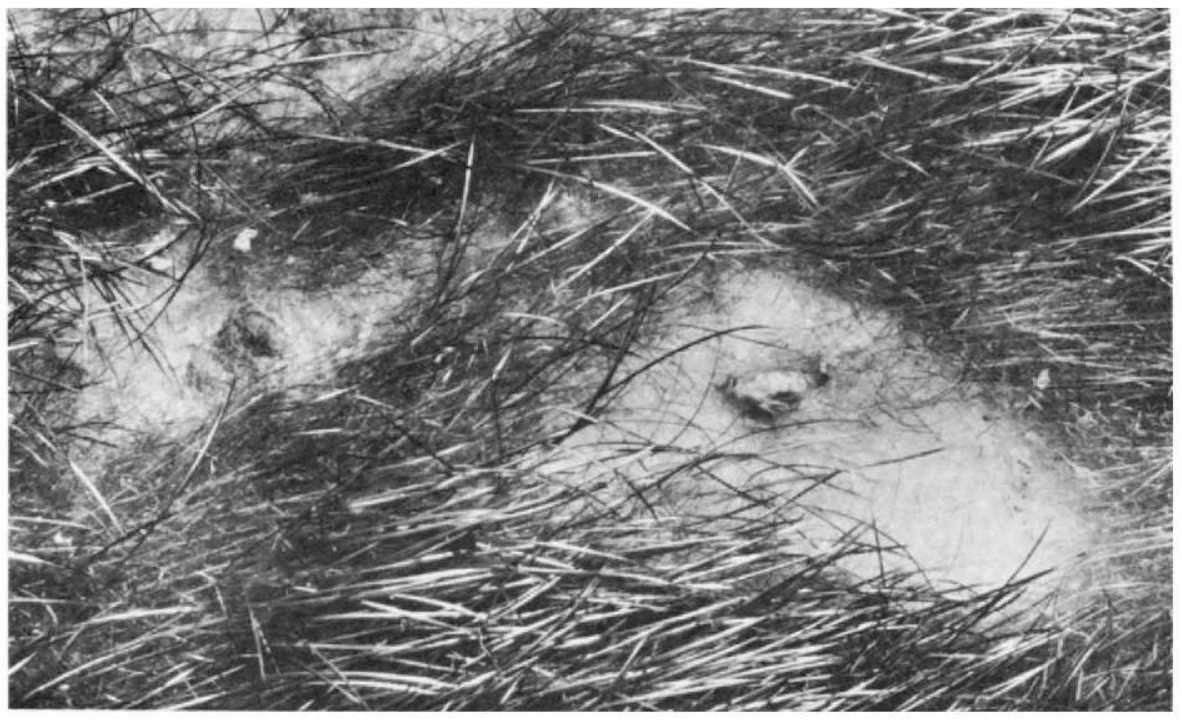

Plate 82-A.-Bare, scabby areas on rump of black pup, molting; 16 July. Note louse at right of center.

(1832)

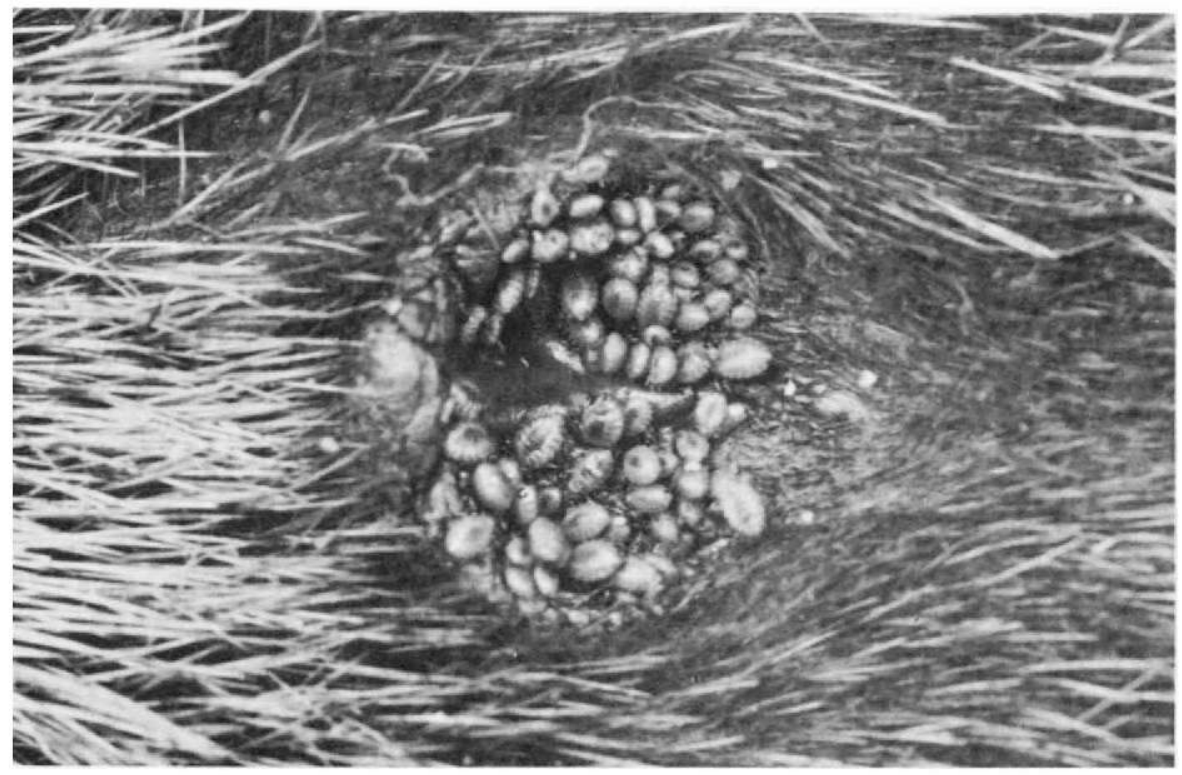

Plate 82-B.-About 130 lice feeding on penial opening of black pup, molting; 11 August; $\times 4$.

(1903) 


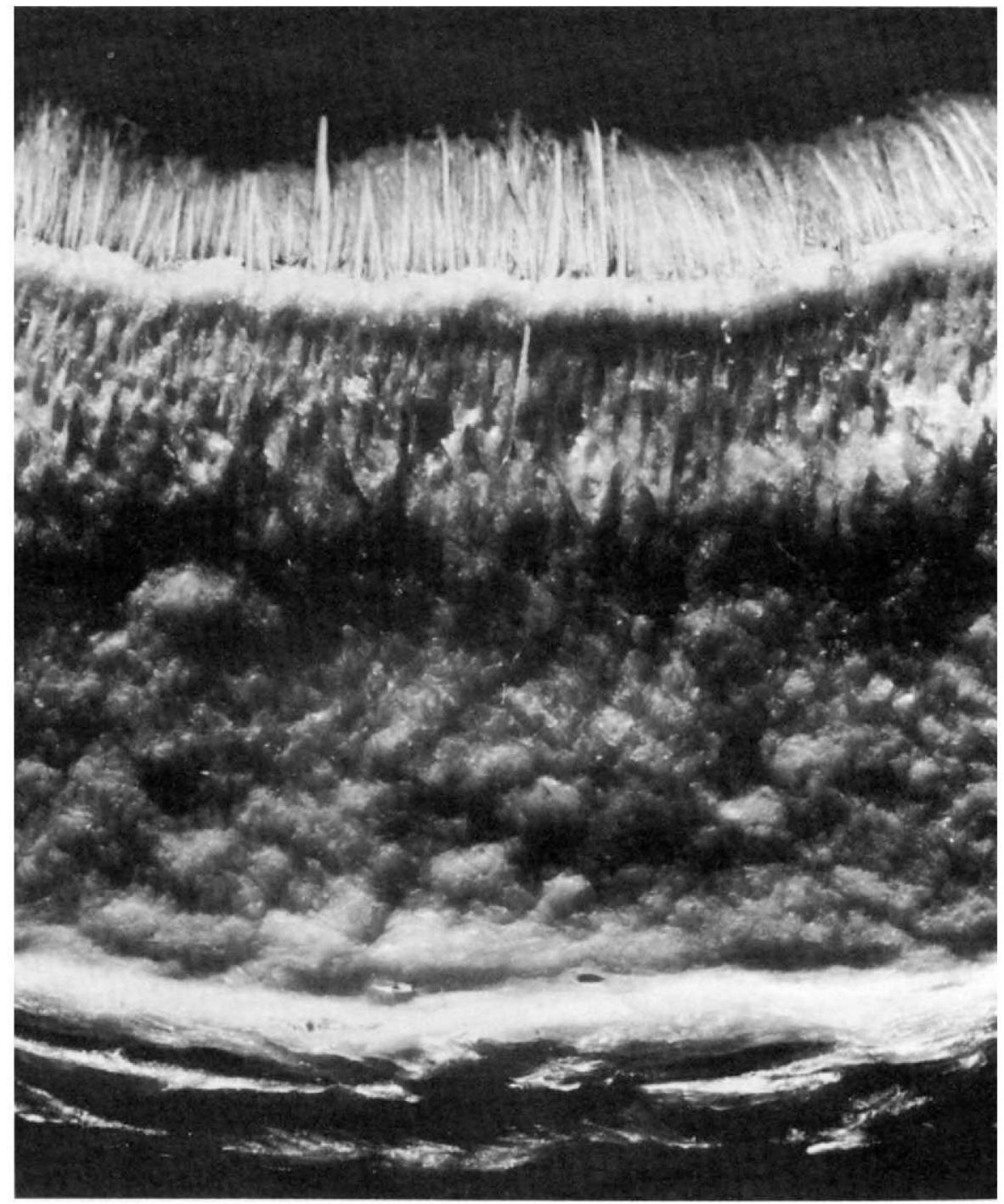

Plate 83.-Pachyderma; subadult male skin rejected from commercial take on St. Paul Island; 3 July; anterior edge of section cut from back; alcohol ; $\times 8 . \quad$ (4167) 


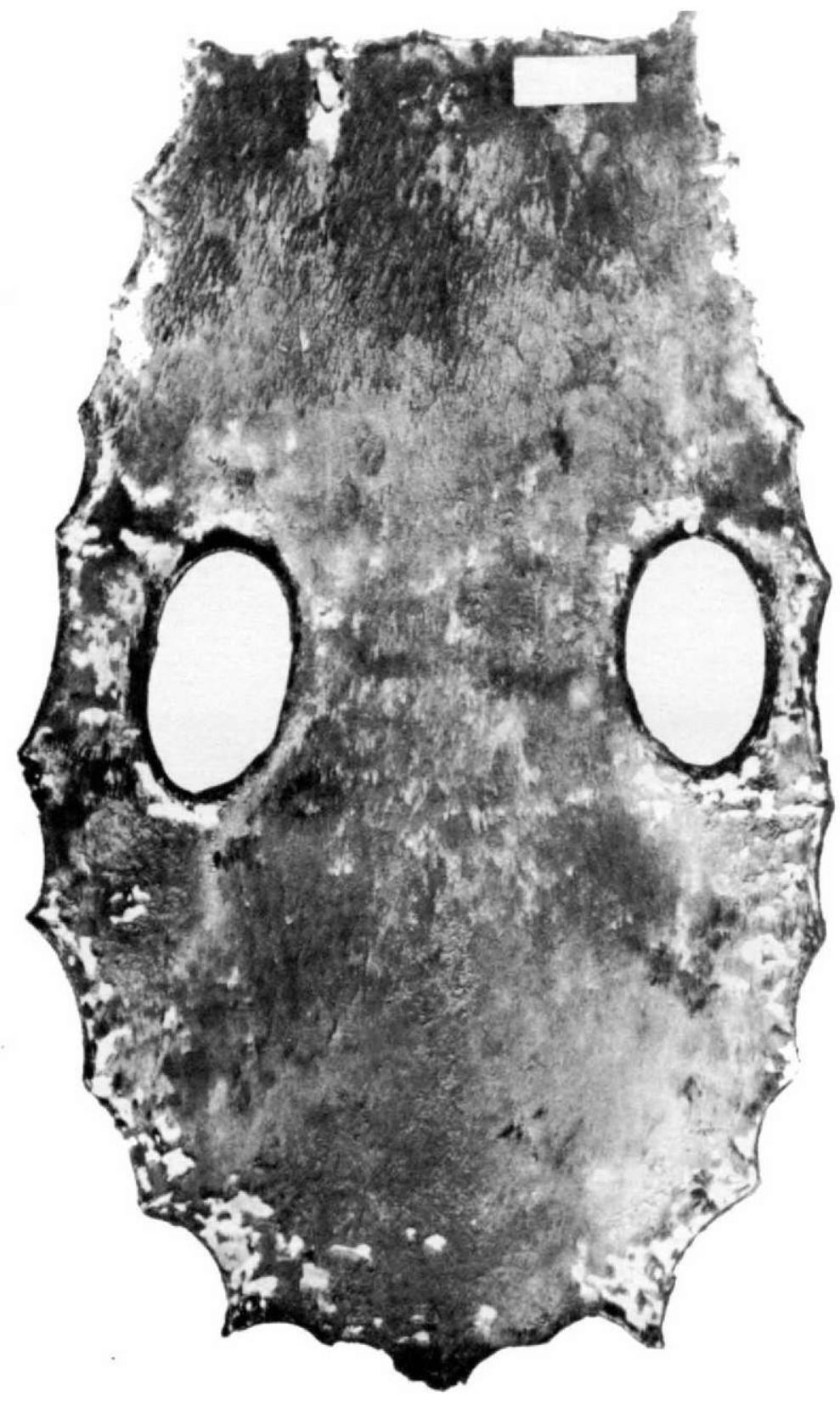

Plate 84.-Pelt of old female exemplifying poor fur quality. Killed 10 August; unhaired in St. Louis on 28 October of following year; dried on hoop.

(3996 ex Harry May) 


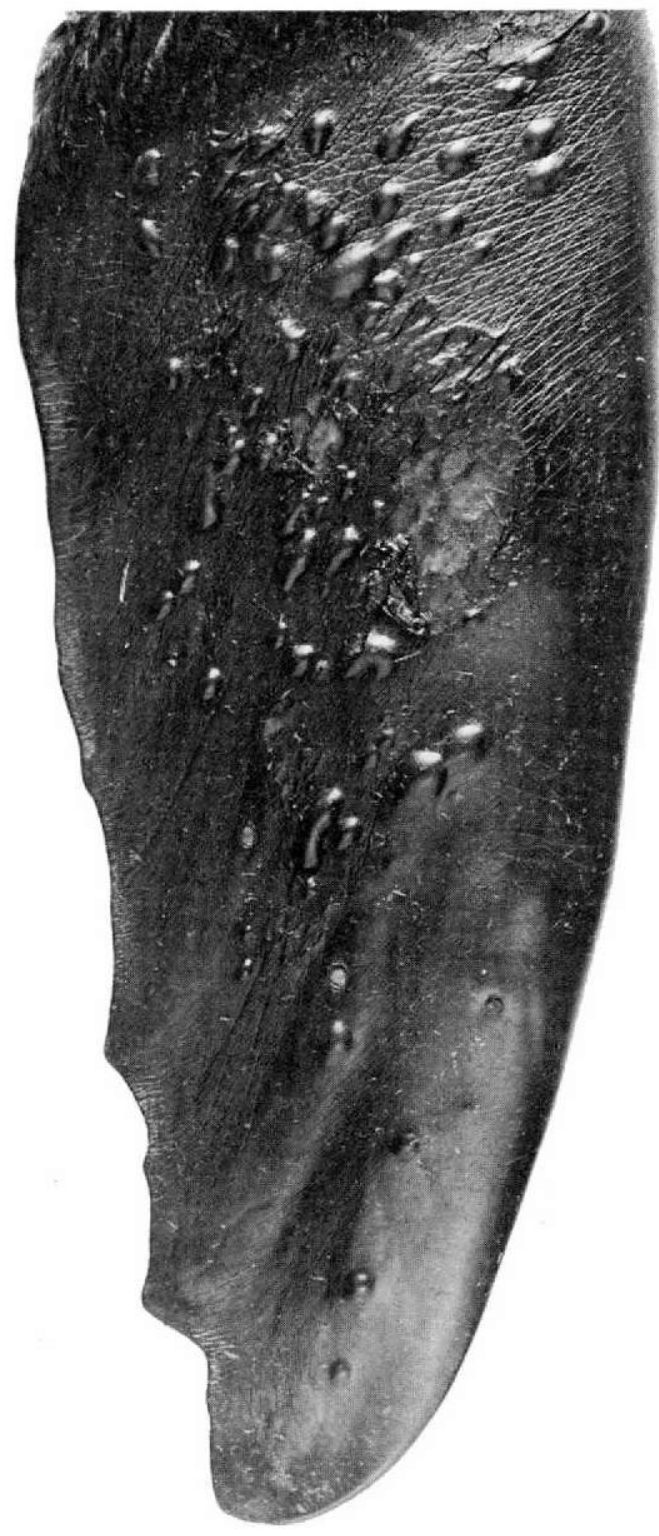

PLATE 85.-Right fore flipper of subadult male, showing blisters on dorsal surface; 16 July; fresh; about $\times 0.6$. On this individual, both surfaces of all flippers were affected. 


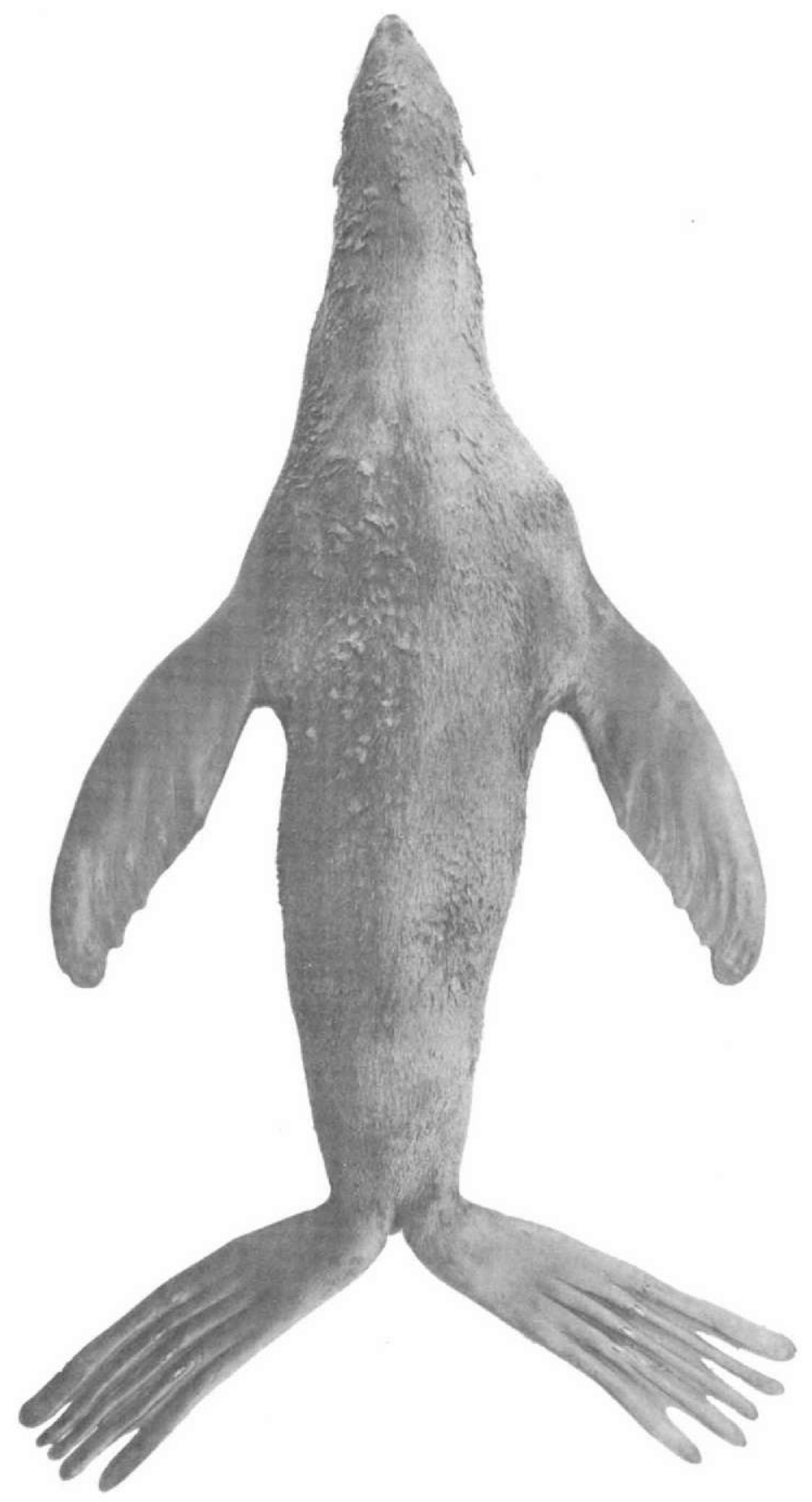

Puate 86.-Cryptorchid killed on 7 July; length $188 \mathrm{~cm}$. ( 74 in.) ; weight $101 \mathrm{~kg}$. (222 lb.). Note slender, ungainly appearance of trunk and limbs; absence of wig and mane. 


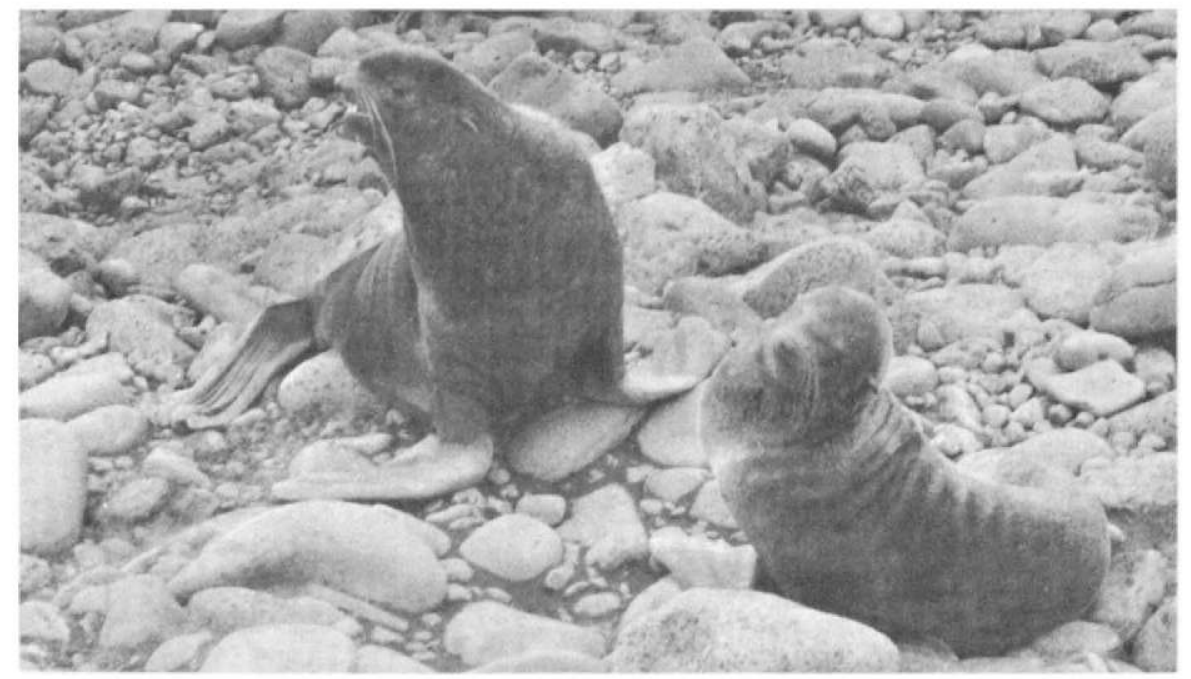

PLATE 87-A.-Cryptorchid in right foreground, treated as "female" by harem bull at left; 15 July.

(1708)

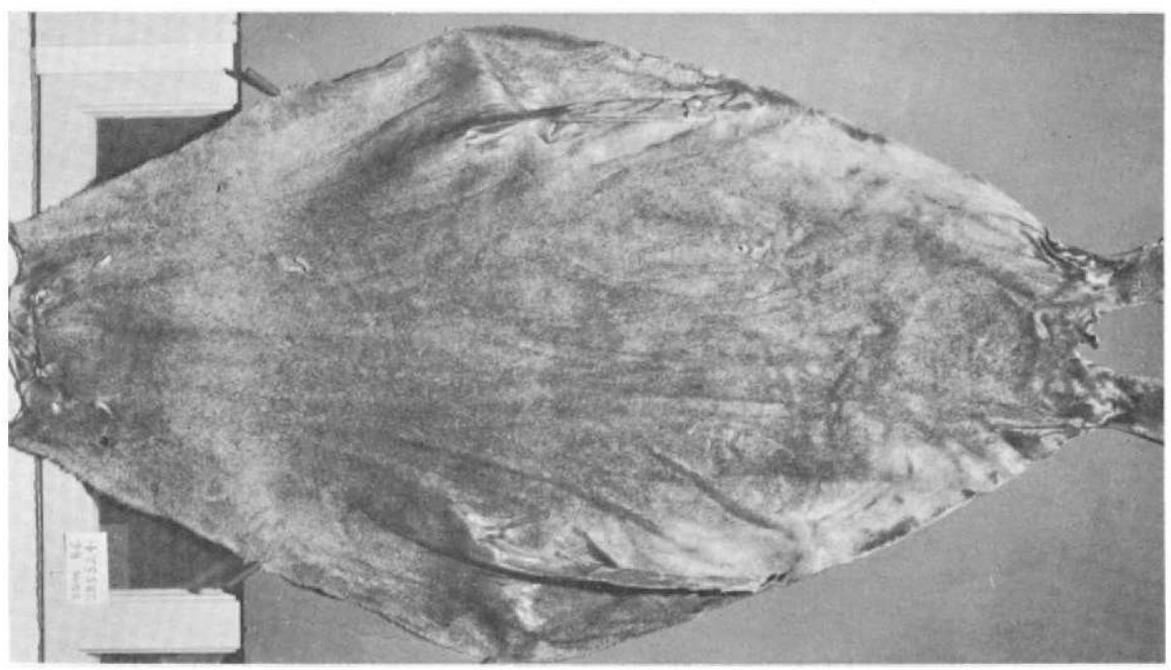

Plate 87-B.-Tanned pelt of same cryptorchid, original body weight $101 \mathrm{~kg}$. (222 lb.) ; length of tanned skin, snout to tip of tail, $200 \mathrm{~cm}$.

(4000 BDM 86) 

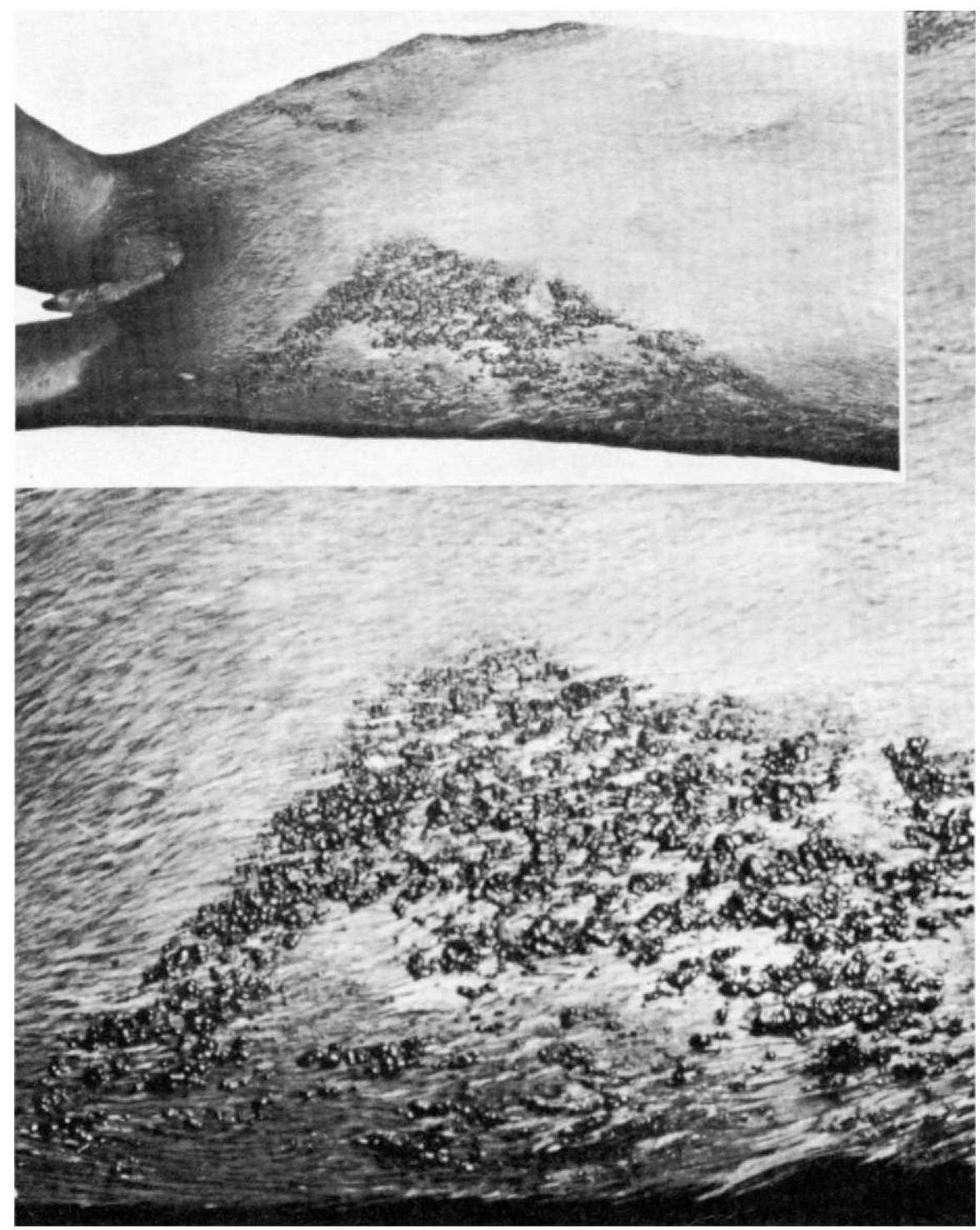

Plate 88.-Brown alga Ectocarpus on left flank and belly of subadult female shot at sea of central California; 12 December; (below) enlarged to natural size. 


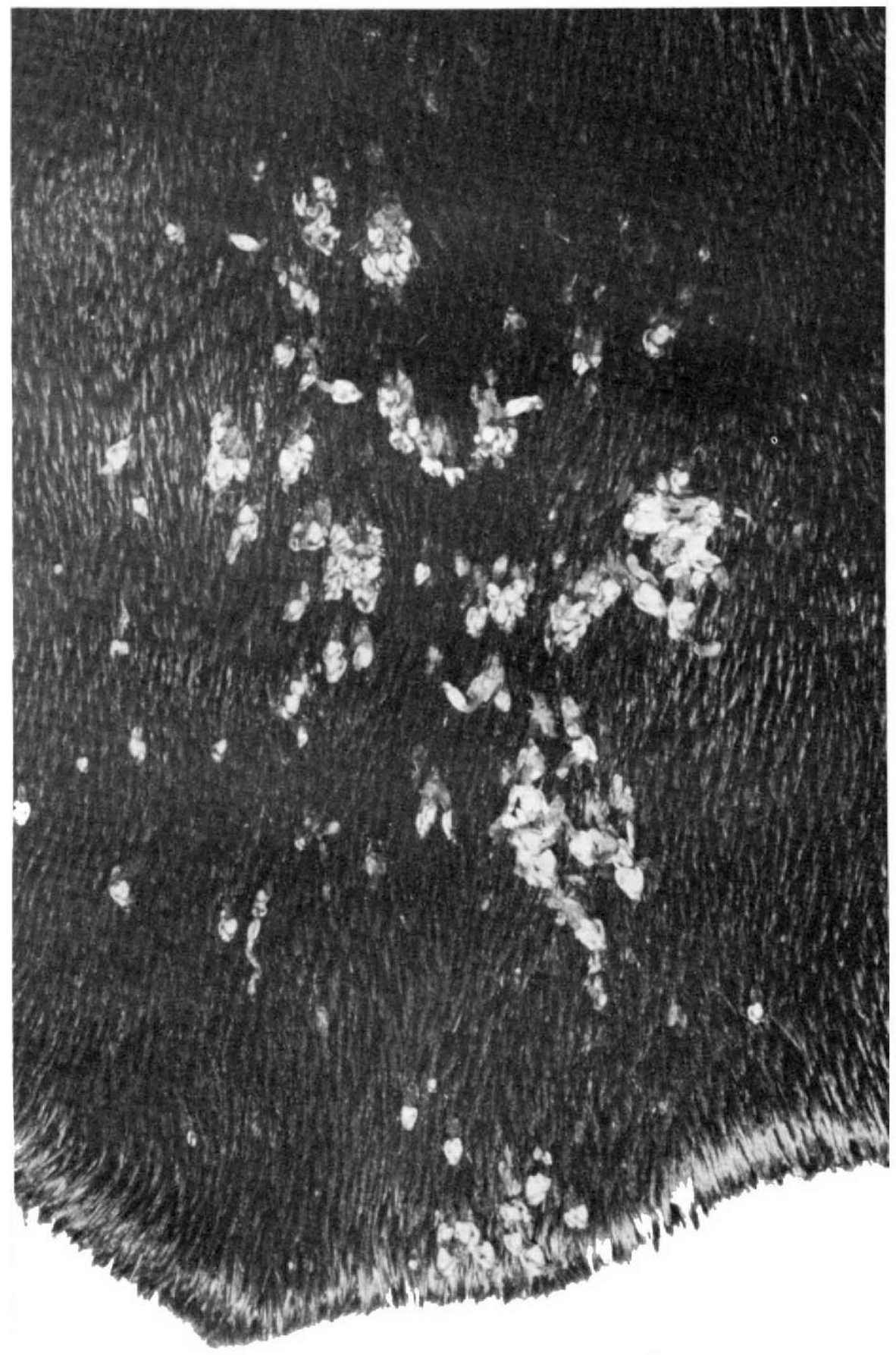

Plate 89.-Barnacles Lepas attached to damp pelage on rump of subadult male about 3 years of age; St. Paul Island; $18 \mathrm{July;} \times 3 / 1$. Pelt has been removed and blubbered; many barnacles have been crushed.

(1.850) 


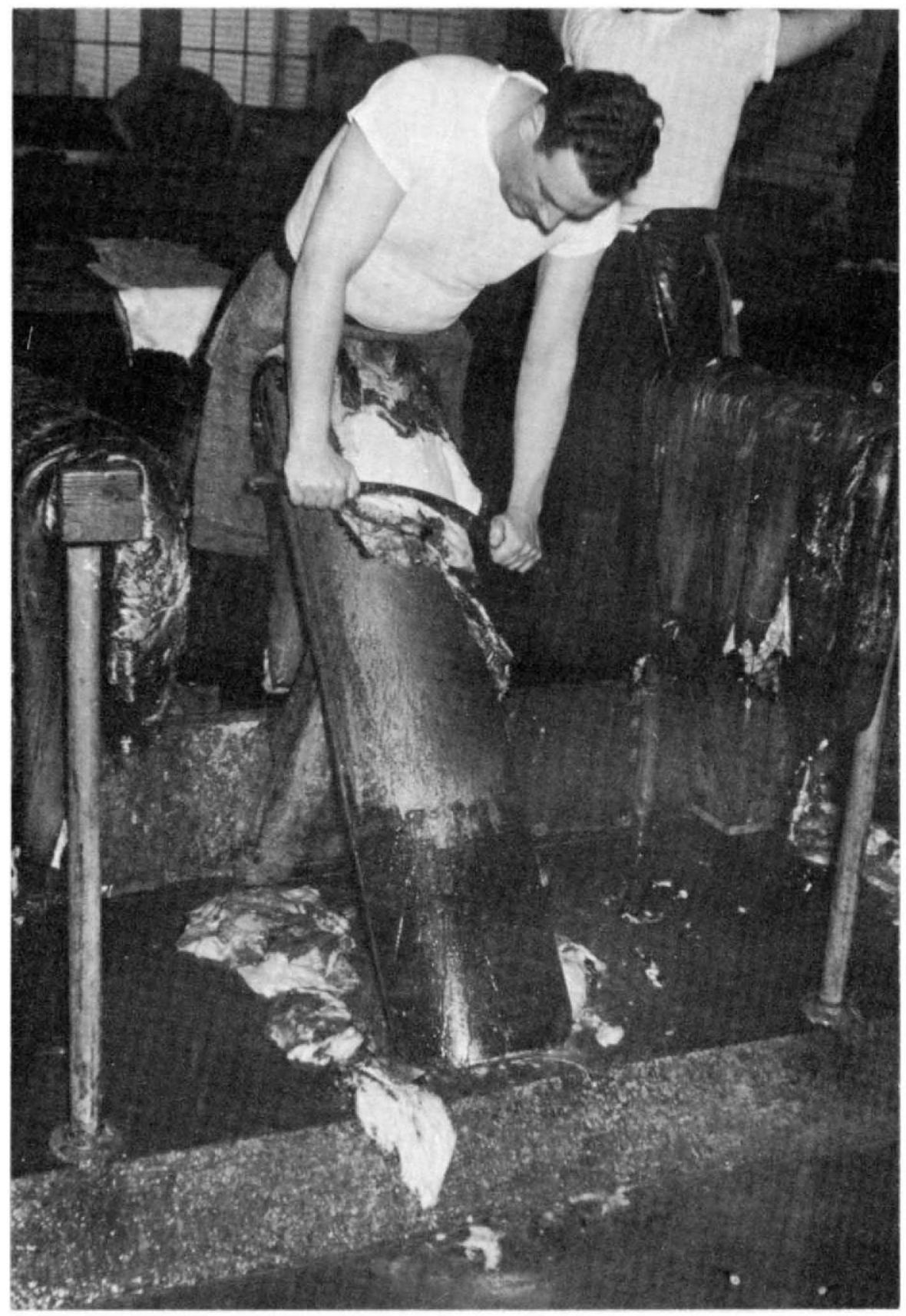

Plate 90.-Blubbering or defatting a sealskin after it has been washed for 24 hours in cold running seawater; st. Paul Island; $16 \mathrm{July}$.

(2031) 


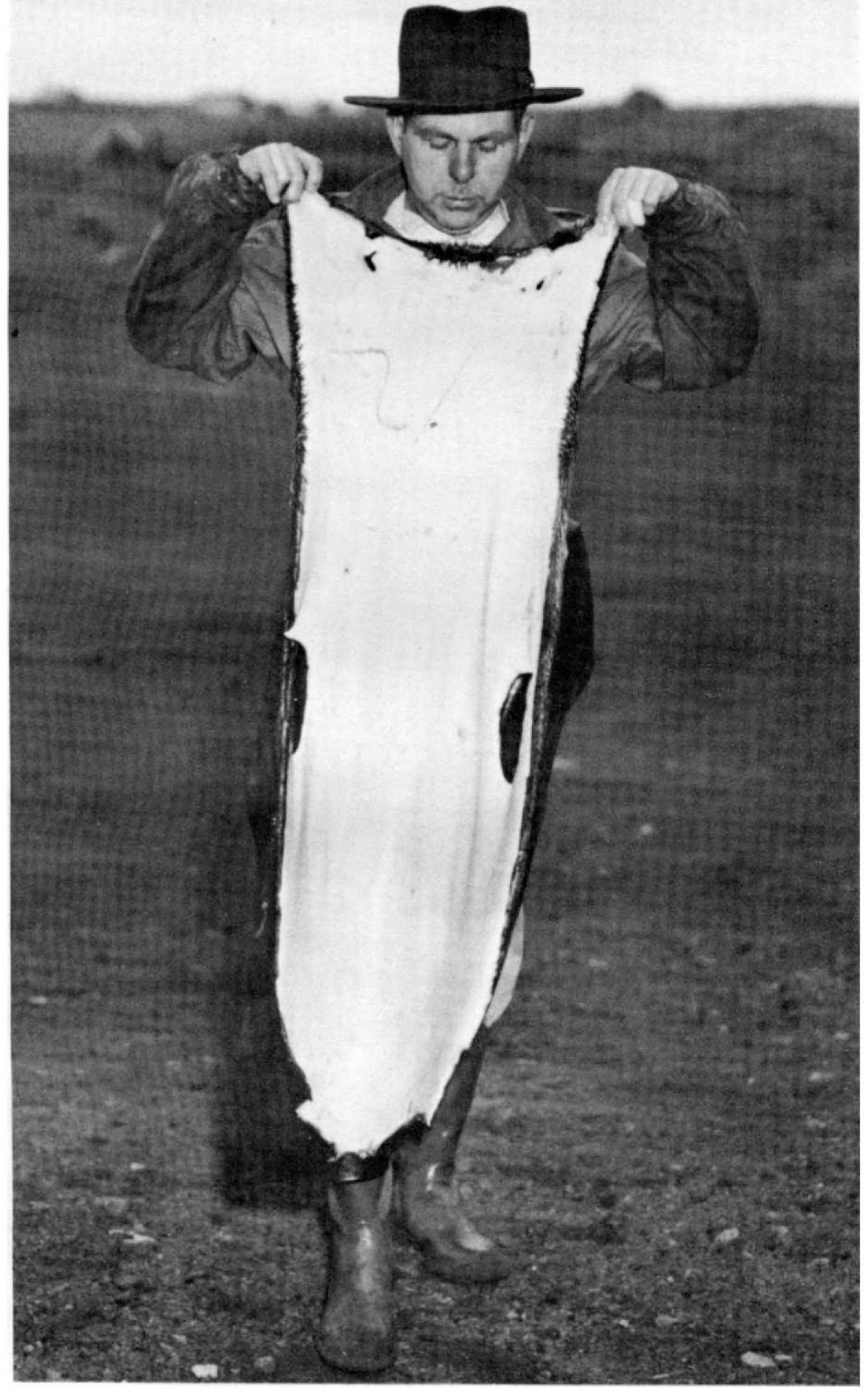

P'LATE 91-Freshly blubbered sealskin.

(2828) 


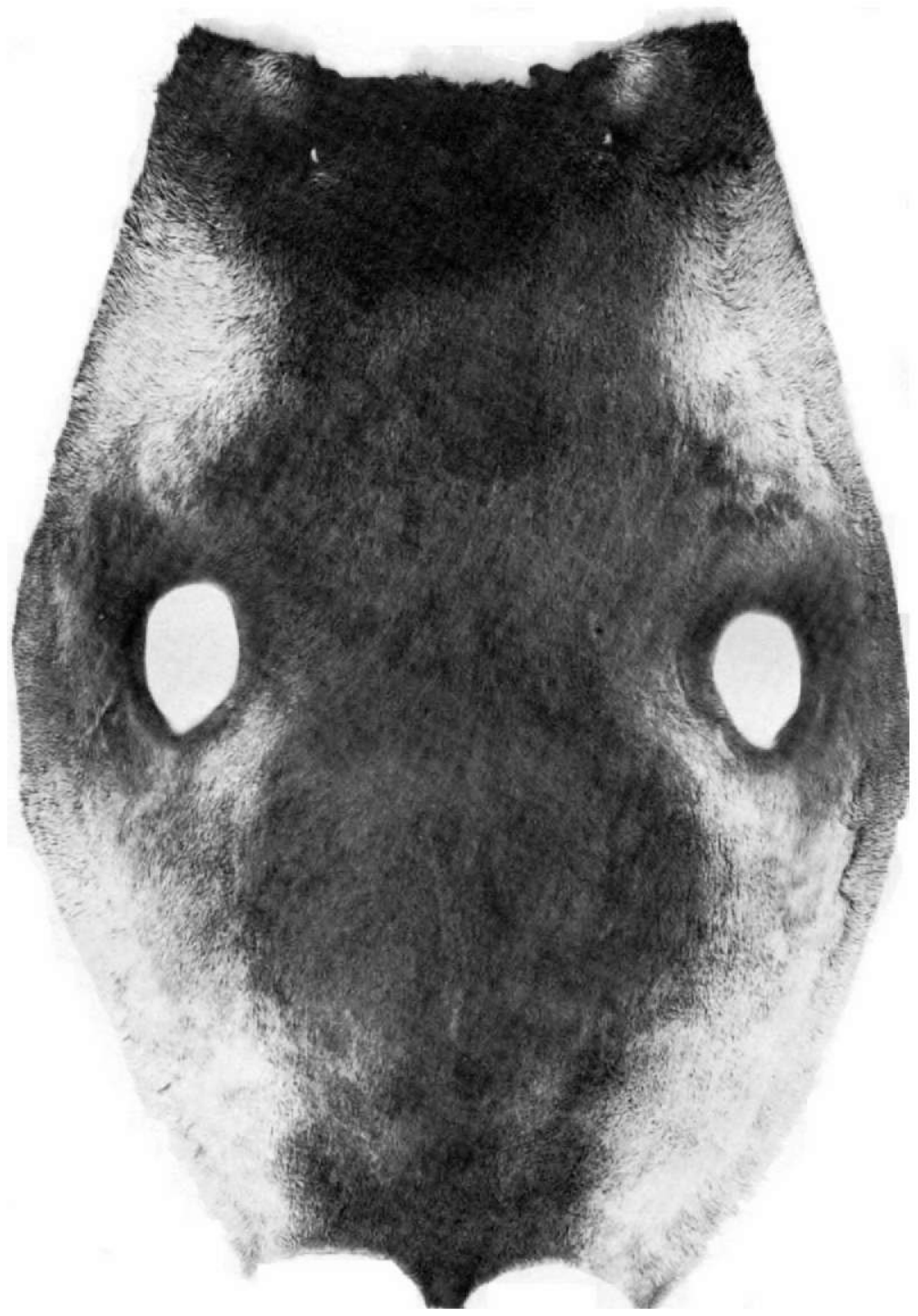

Plate 92.-Commereial sealskin taken on 27 July from subadult male about 3 years of age; skin blubbered, wrung, slaken, and dried under fan for 2 hours; weight $1.93 \mathrm{~kg} .(4.25 \mathrm{lb}$. $) ; \times 1 / 6$.

(2420) 


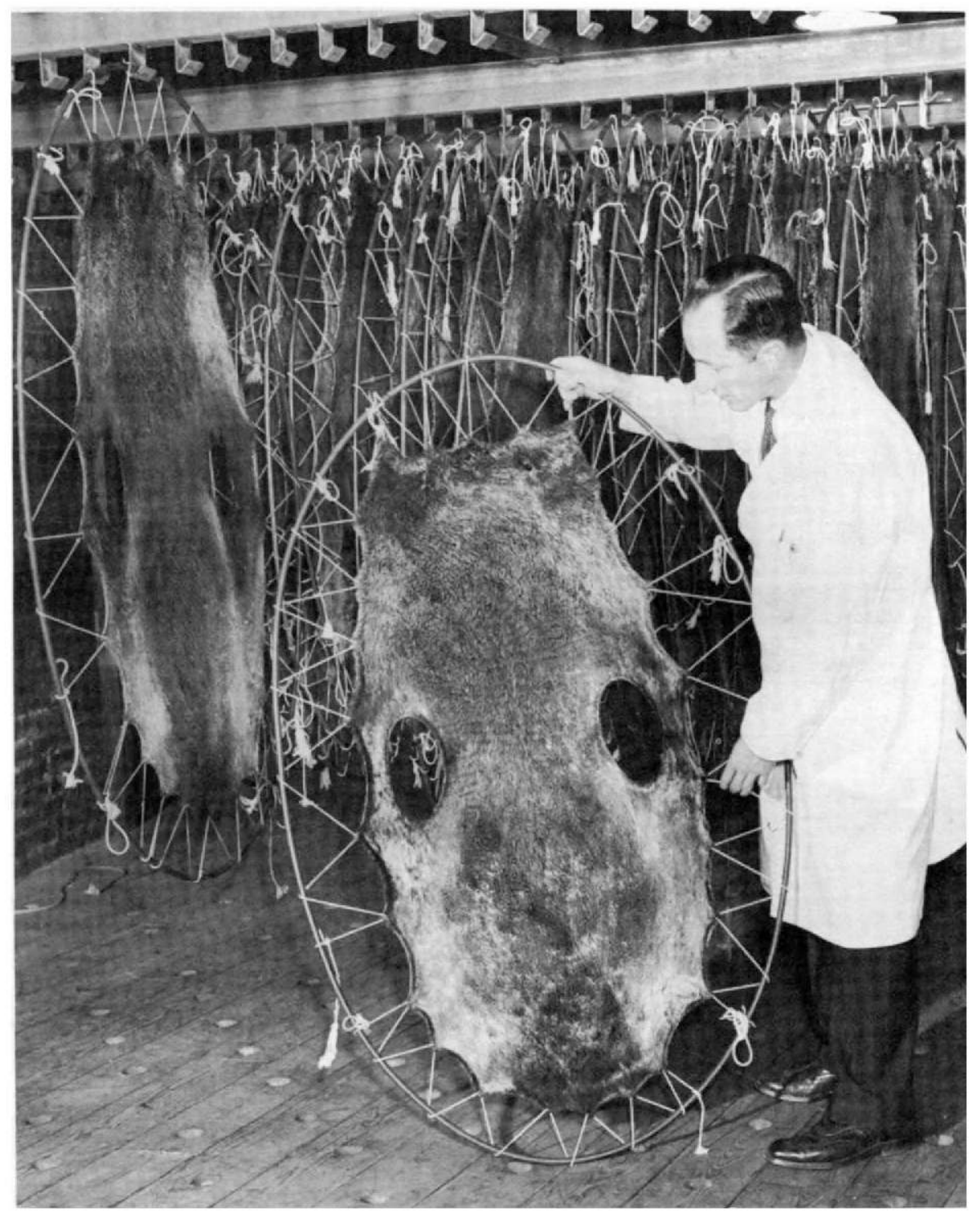

Plate 93.-Sealskin at processing plant, having been washed, hooped, and dried in preparation for unhairing.

(Fouke Fur Co.) 


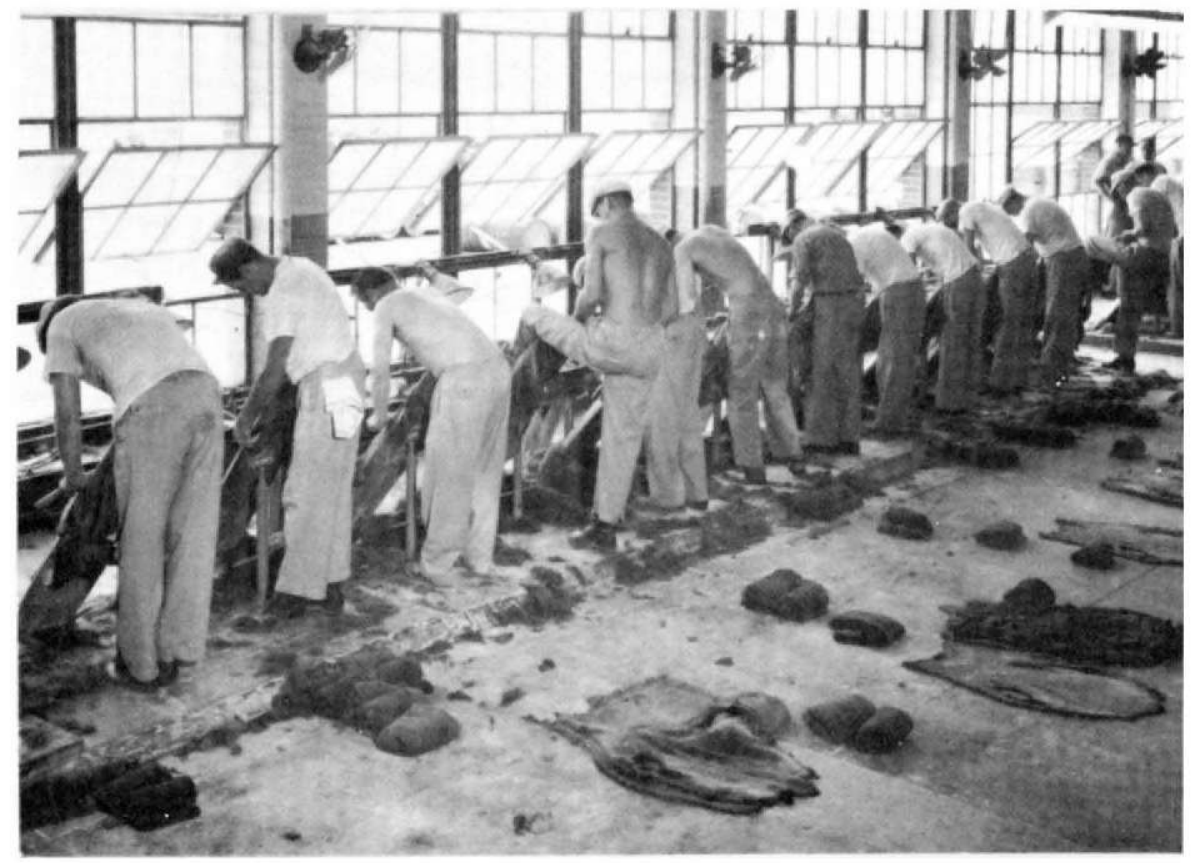

Plate 94-A.-Unhairing.

(Fouke Fur Co.)

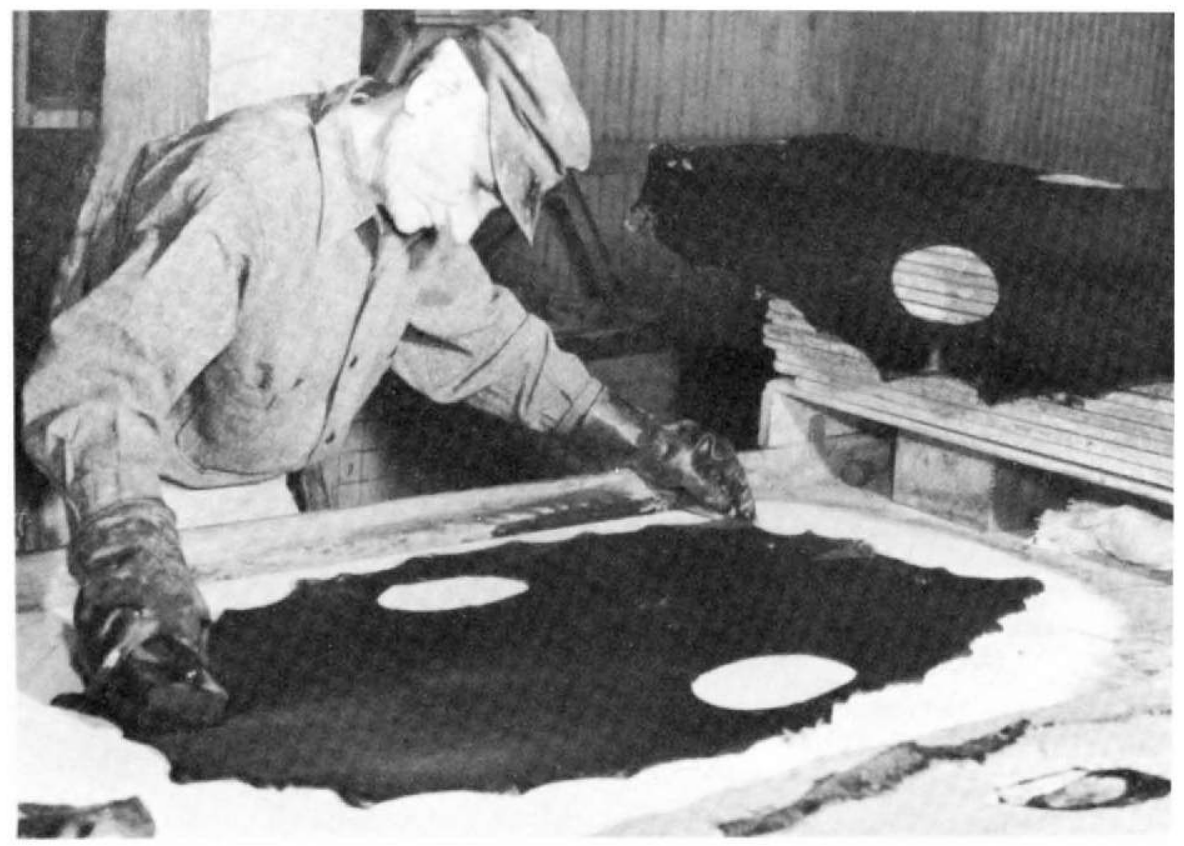

Puate 94-B.-Dyeing.

(Fouke Fur Co.) 


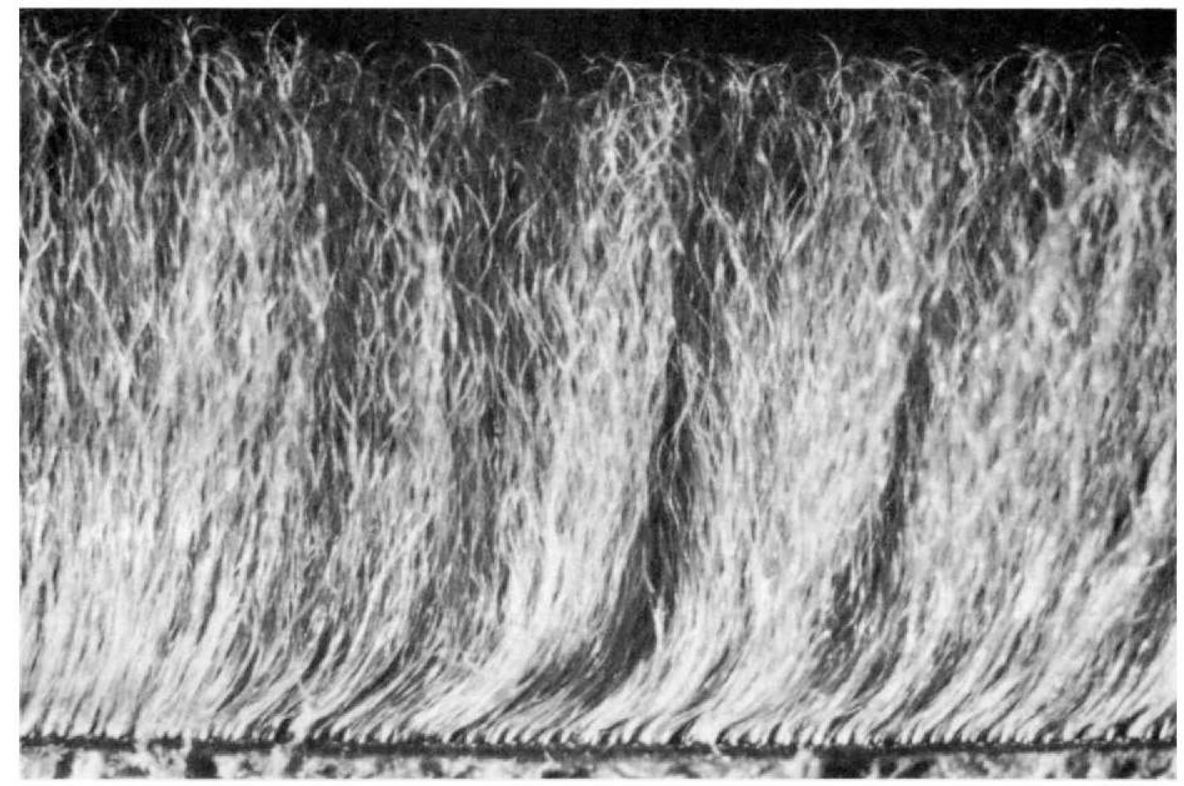

Plate 95-A.-Fragment of untanned sealskin immediately after the unhairing process; Iateral view; anterior end toward viewer's left; $\times 7$.

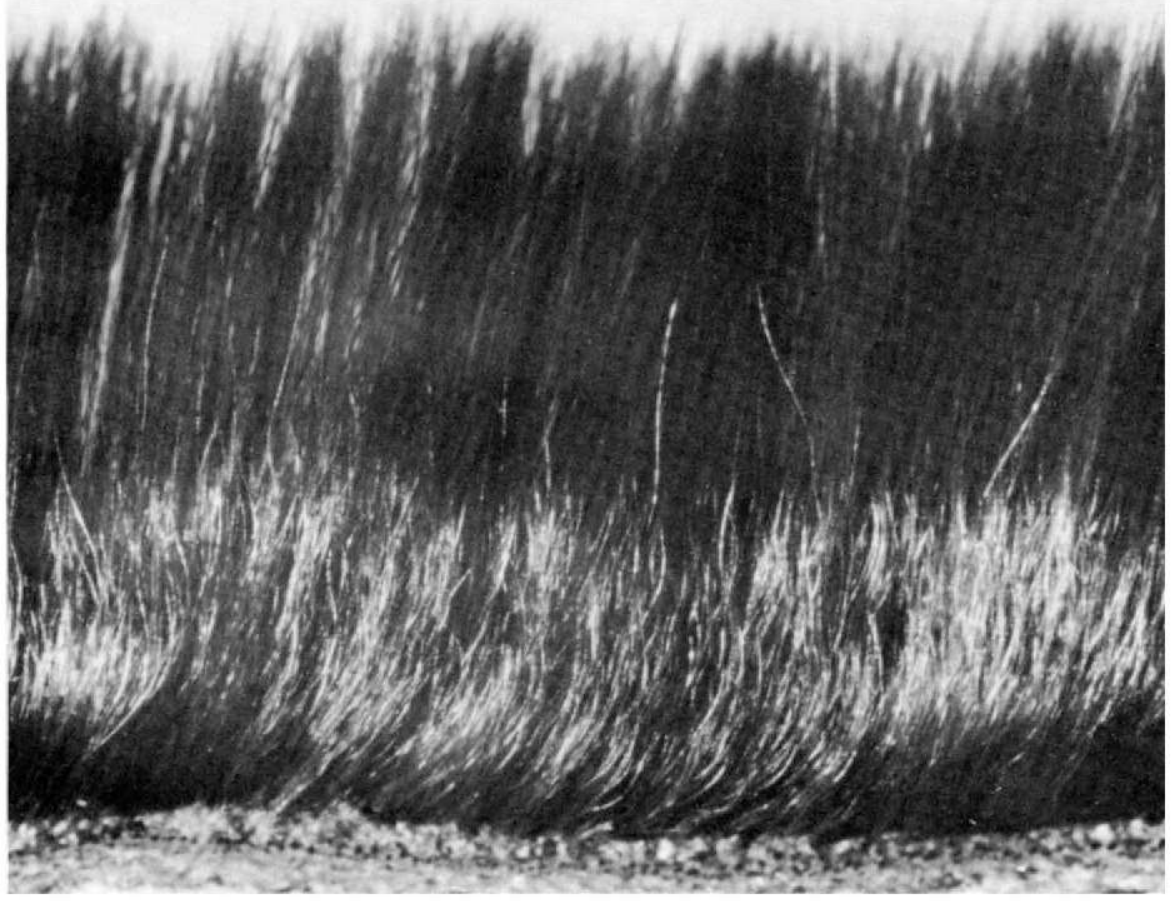

PLATE 95-B.-Fragment of finished sealskin after all processing, including tanning, dehairing, and brown-dyeing; near nosterolateral view; $\times 7$.

(2924) 


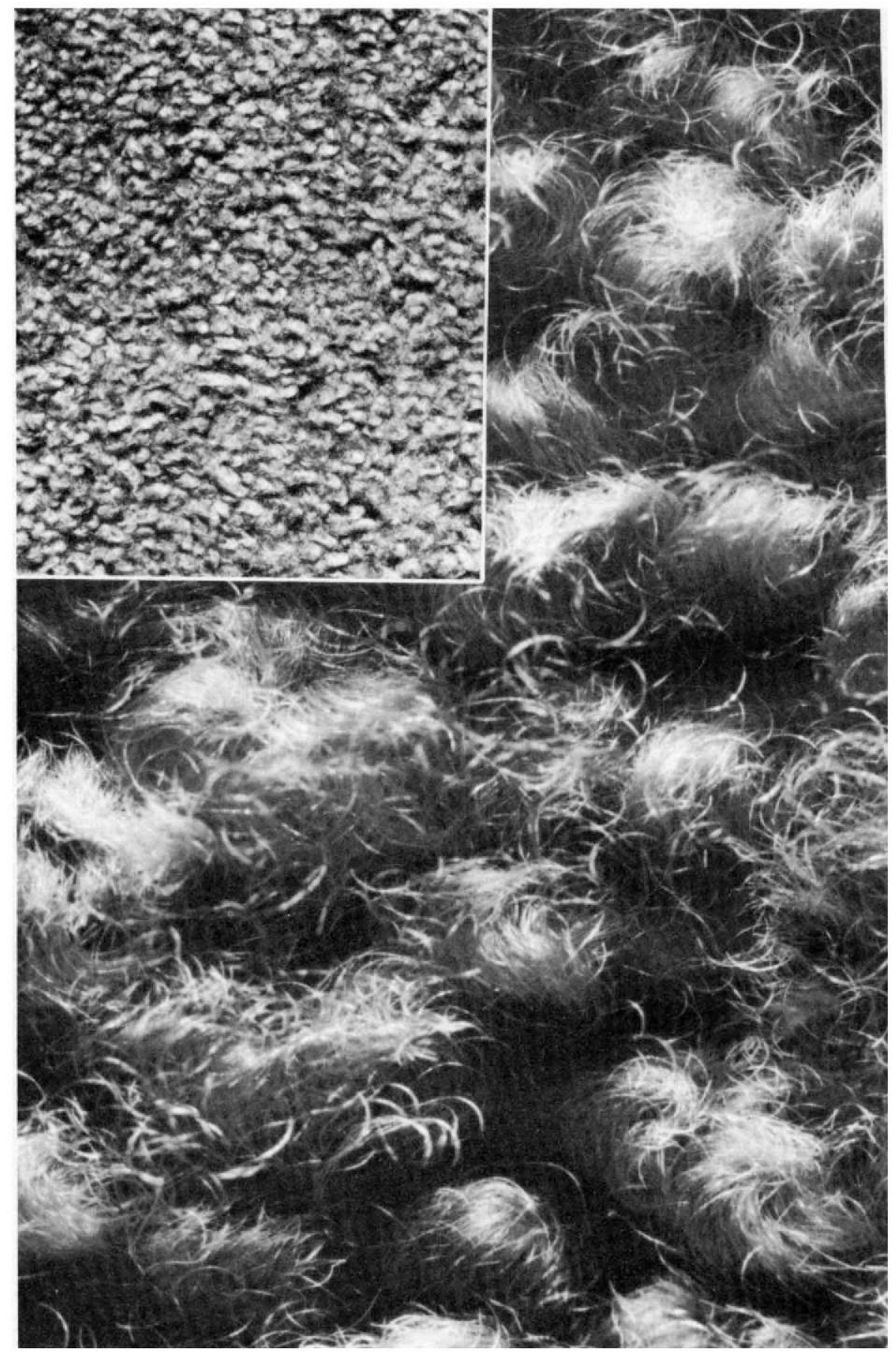

Plate 96.--Looking down on fragment of tanned, unhaired pelt from neck of 4-year-old male; killed $22 \mathrm{July}$; anterior end at top ; $\times 10$. Insert is.natural size.

(4006 and 4002) 


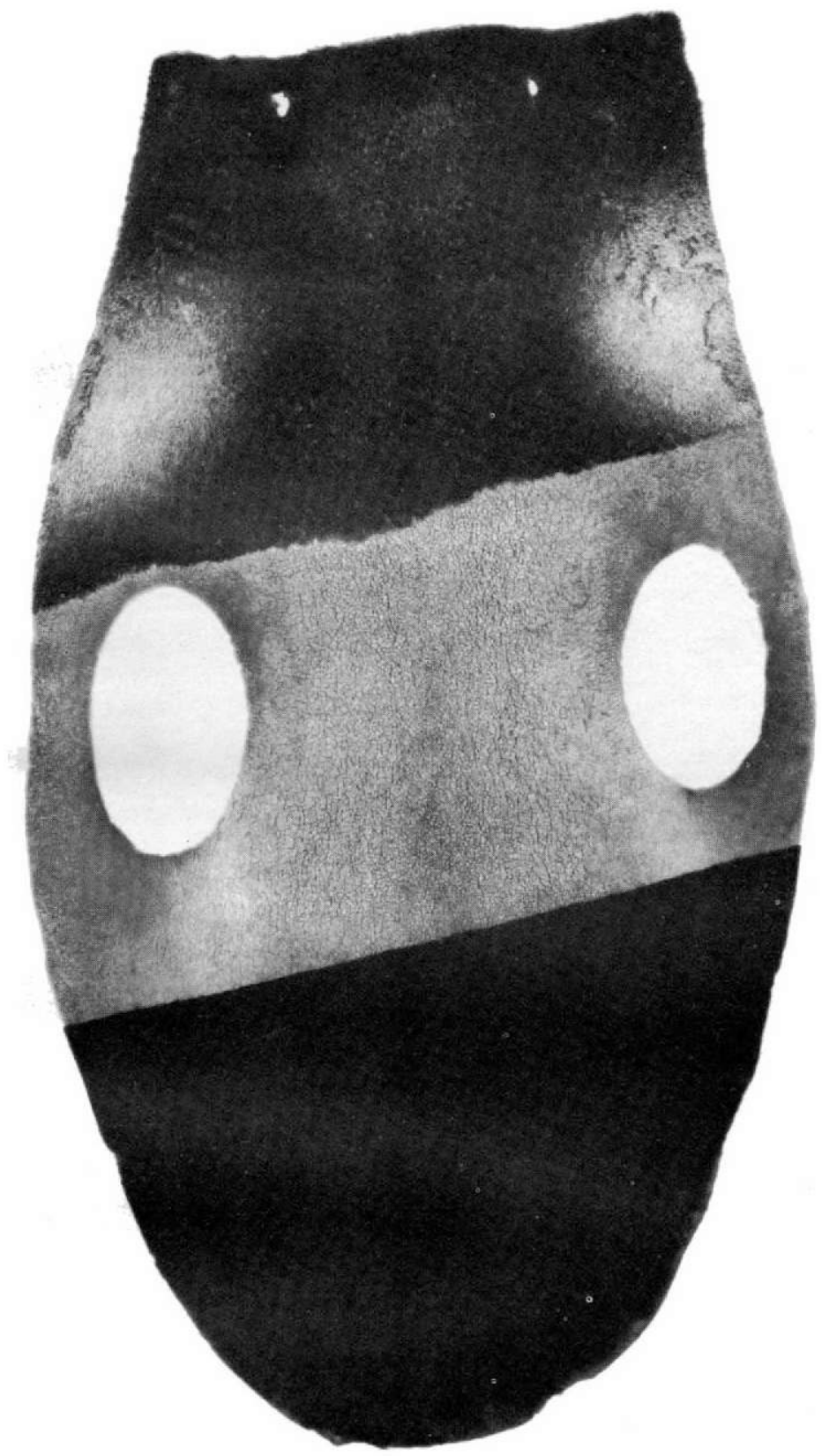

Plate 97.-Demonstration pelt showing three stages of processing (from top to bottom) : "tanned in the hair," with all fibers intact; "unhaired," with guard hairs removed; and "finished," with fur flbers straightened and dyed brown. Specimen courtesy Fouke Fur Co.

(2718) 


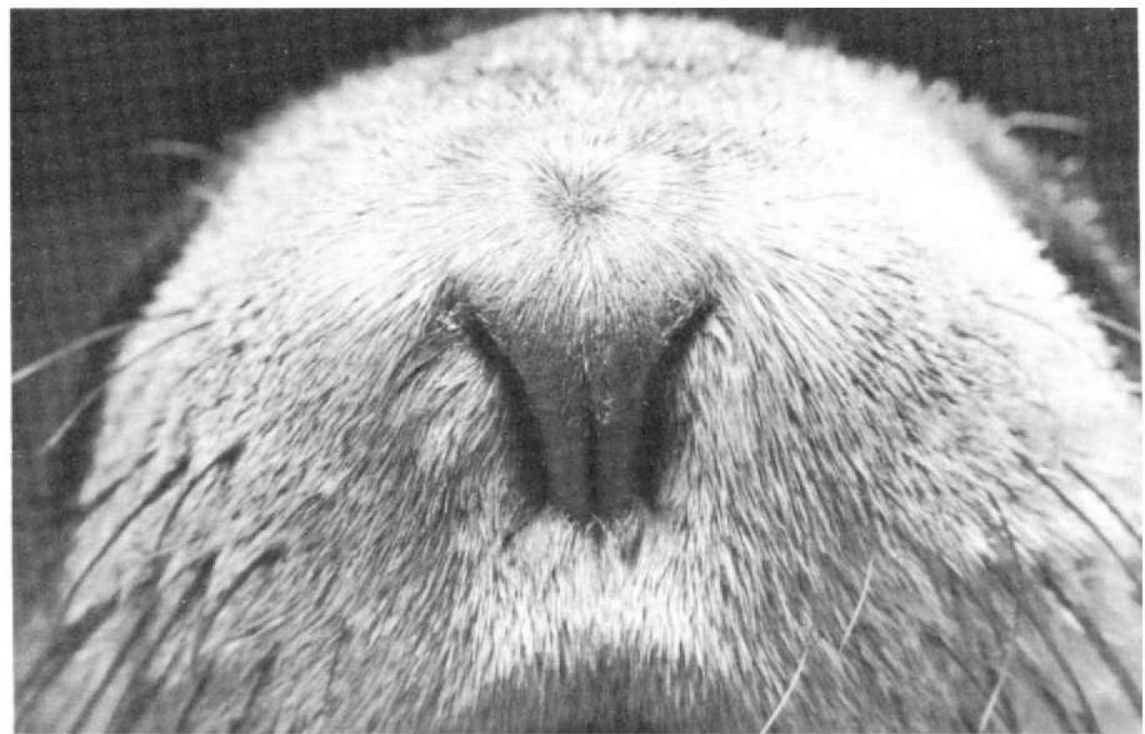

I'LATE 98-A.-Snout of yearling male; 26 September; about $\times 1.8$. The "cowlick" above the rlinarium is donble on certain individuals.

(4062)

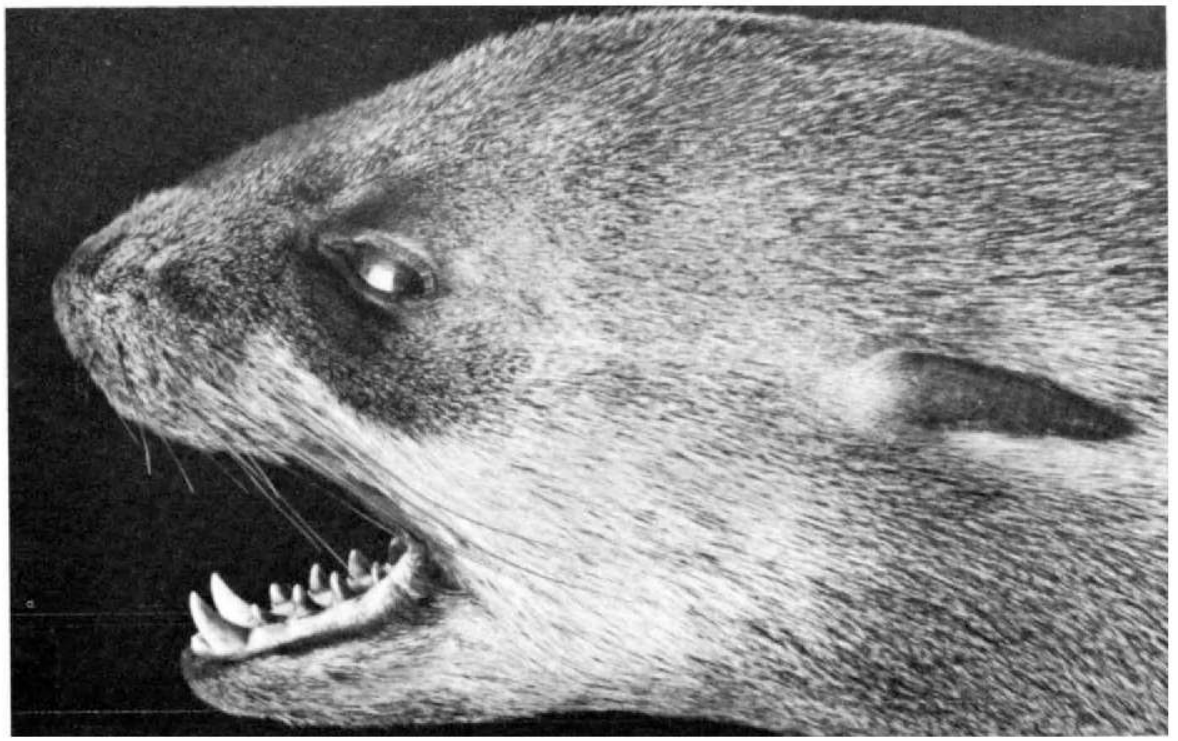

PiAtr 98-B.-Profile of head of yearling female showing mouth ; 3 October.

(4067) 


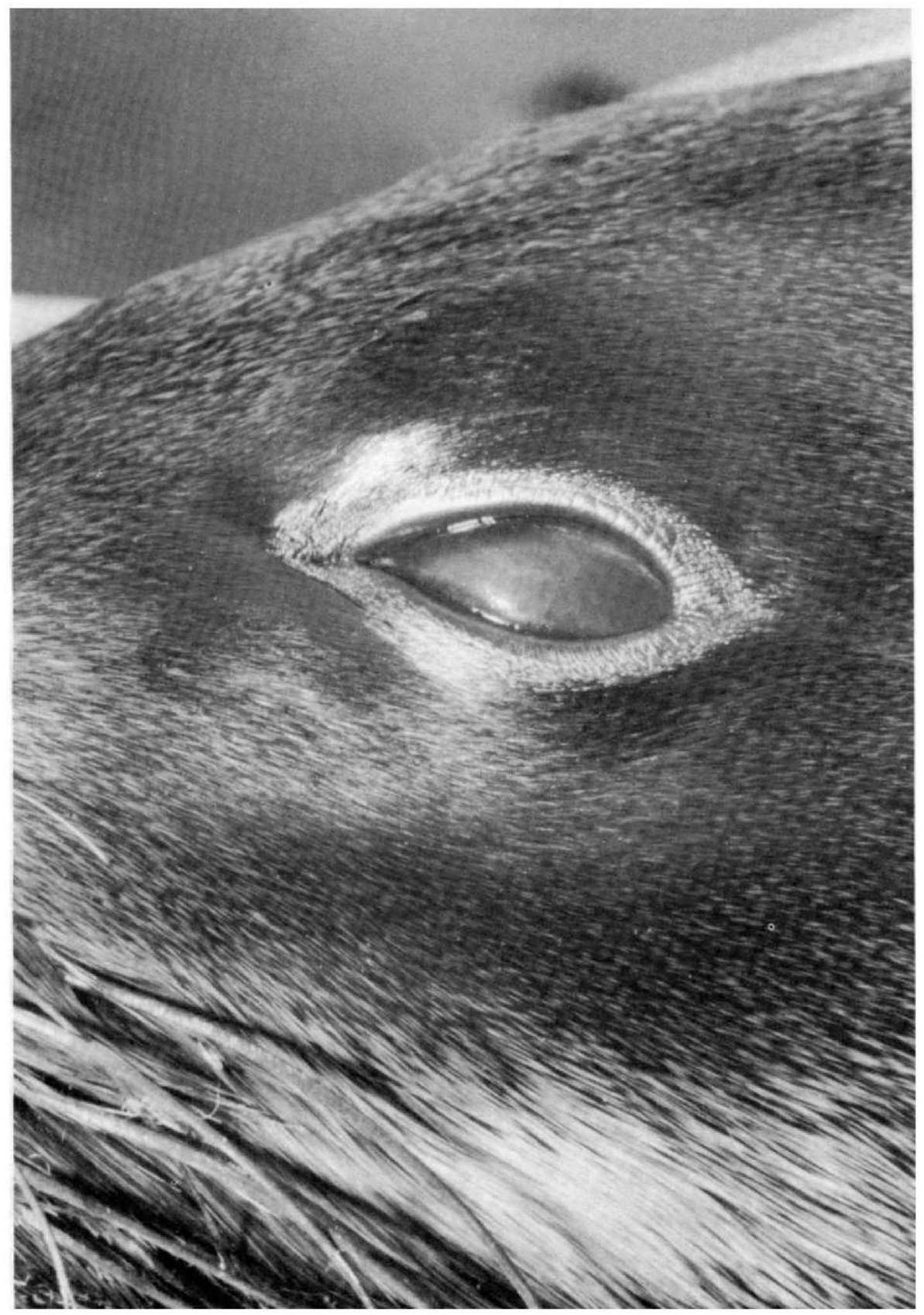

Plate 99.-Eye of 3-year-old remale; Seattle Zoo; 20 December; $\times 2$.

(3884) 


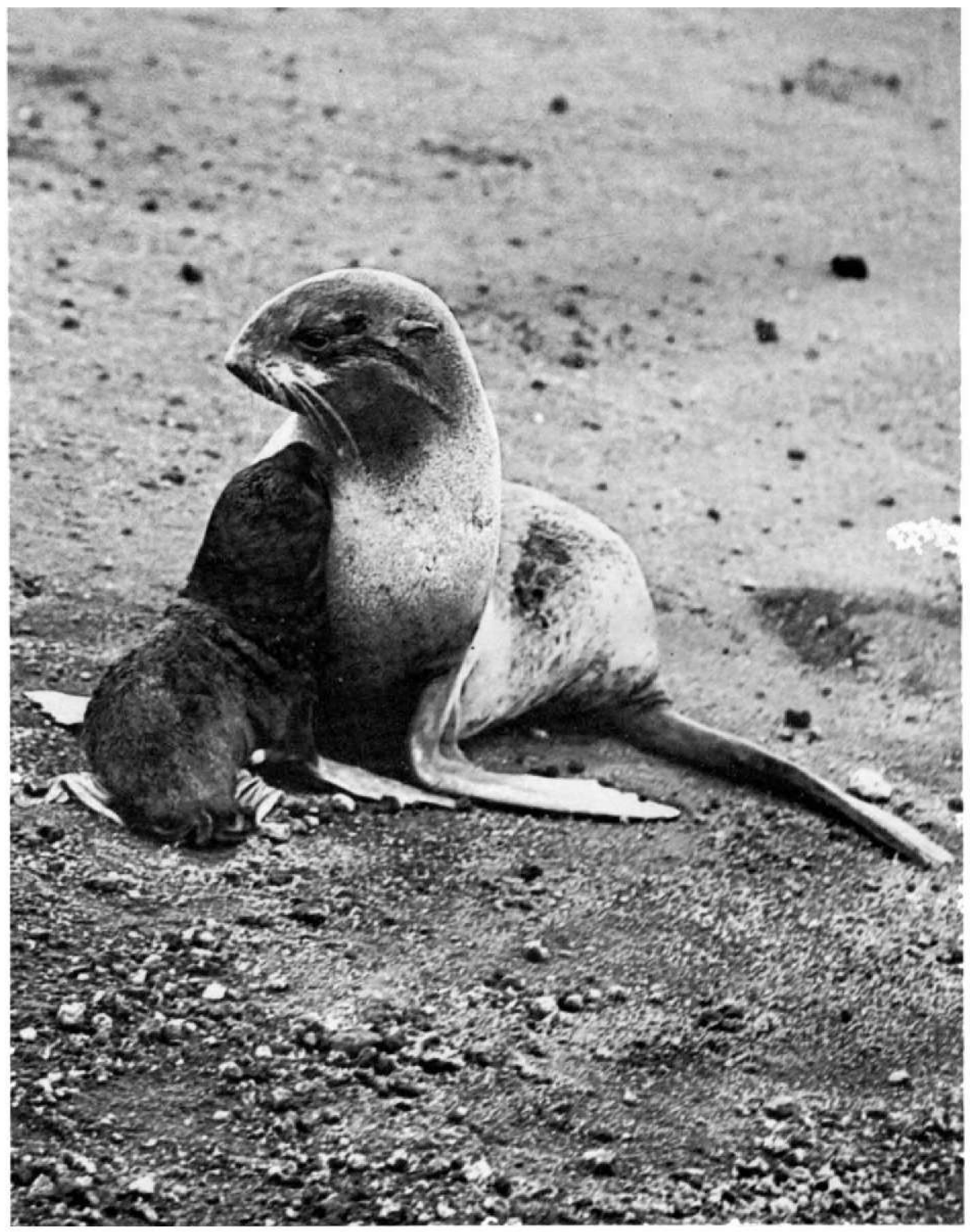

Plate 100.- "Tears" on the cheek of a female seal on a warm, quiet day; 15 July. (2625) 


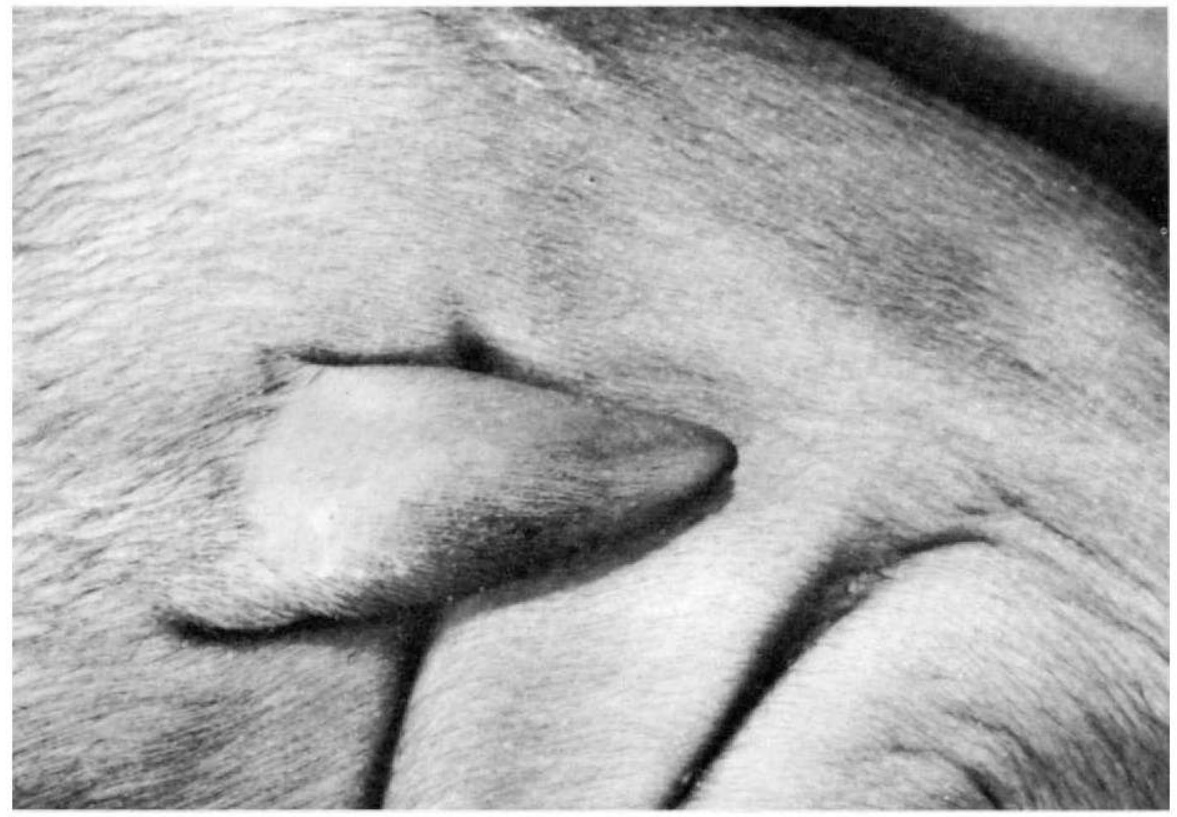

Plate 101-A.-Left ear of $1.19 \mathrm{~kg}$. fetus; $\times 10$.

(4137)

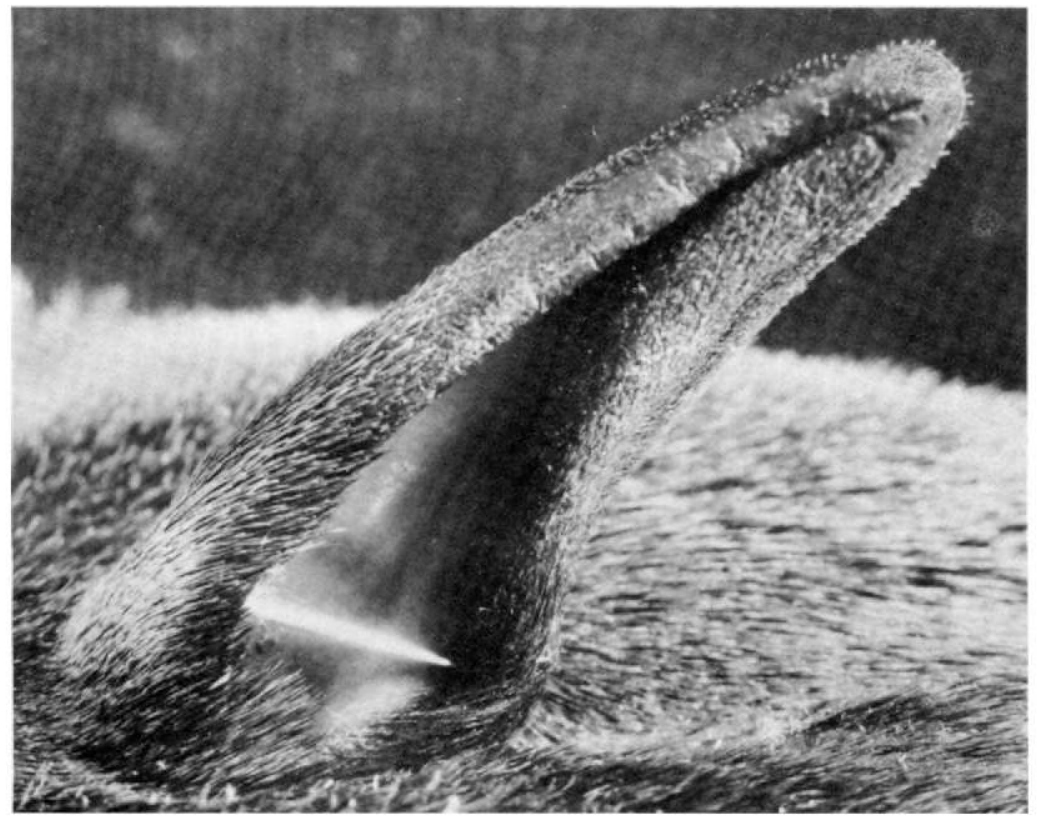

Plate 101-B.-Ear of 9-year-old female; edges held apart by a pin ; 17 September ; $\times 3$.

(4048) 

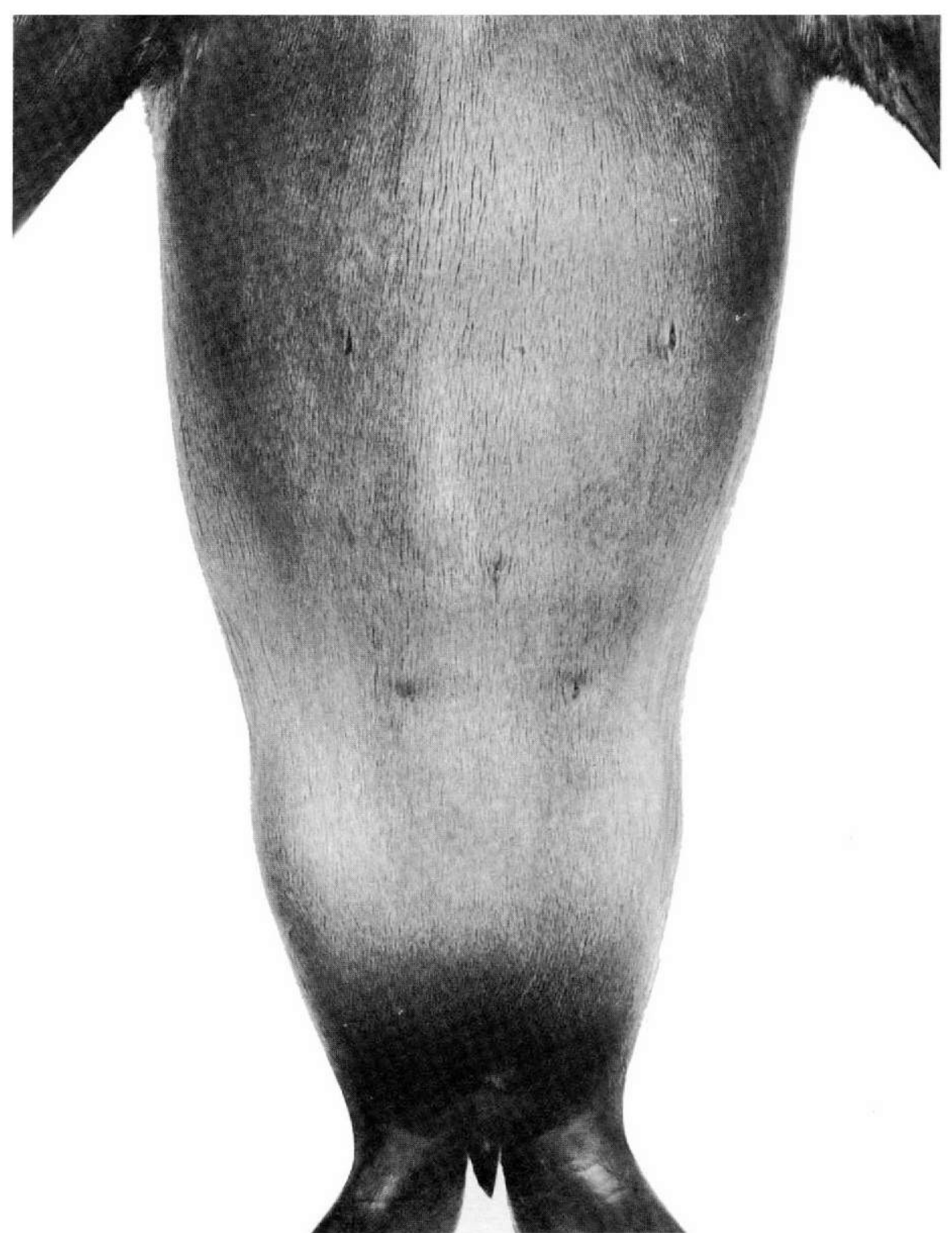

Plate 102.-The four mammary teats and the navel (center) on an adult female; 20 July.

(1848) 


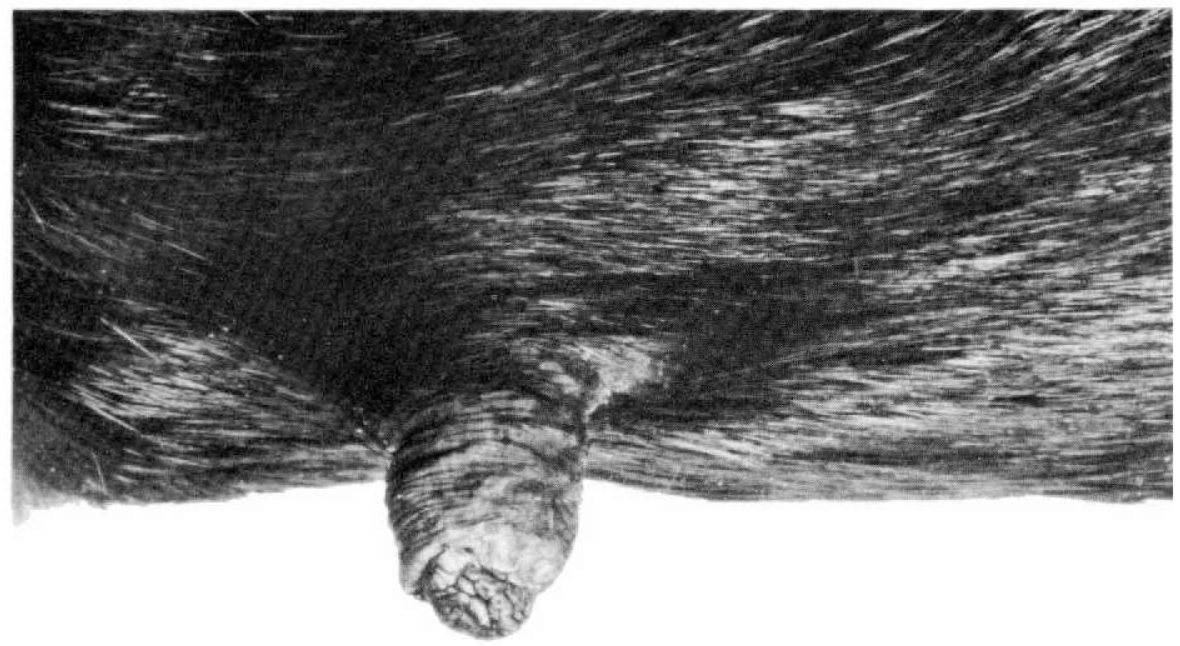

PLATE 103-A.-Right anterior teat, forcibly extended and hardened in formalin, of old, parous female; 2 September; natural size.

(4218)

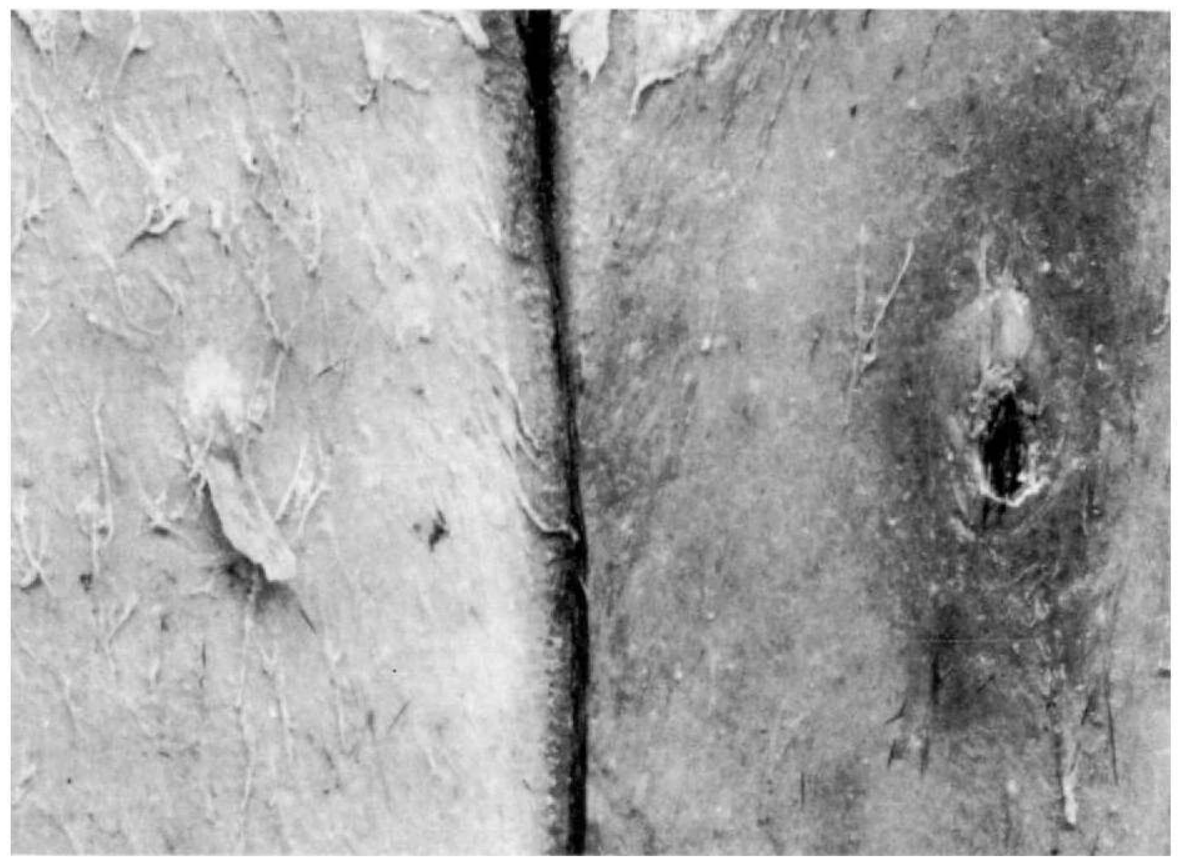

PLate 103-B.-Inside of two skins showing one posterior teat on a nulliparous (left) and on a parous, lactating individual (right). Seals killed 27 September; skins held in salt until $12 \mathrm{May}$; blubbered and photographed.

$(2735 \mathrm{~A})$ 


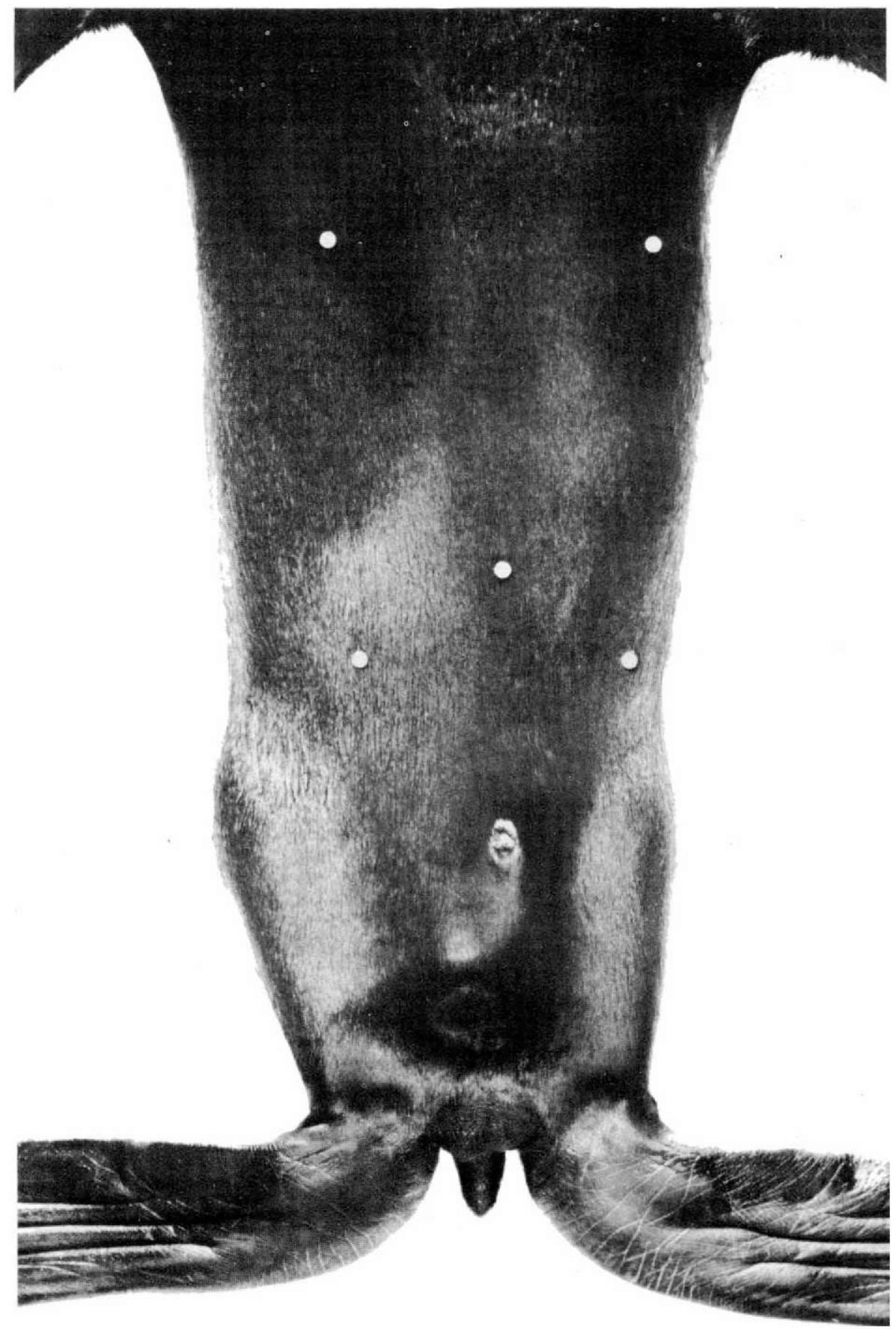

Plate 104.-White discs show location of the navel and 4 rudimentary teats on a 6 -year-old male; 9 September; about $\times 1 / 1$. $(4028 \mathrm{~A})$ 


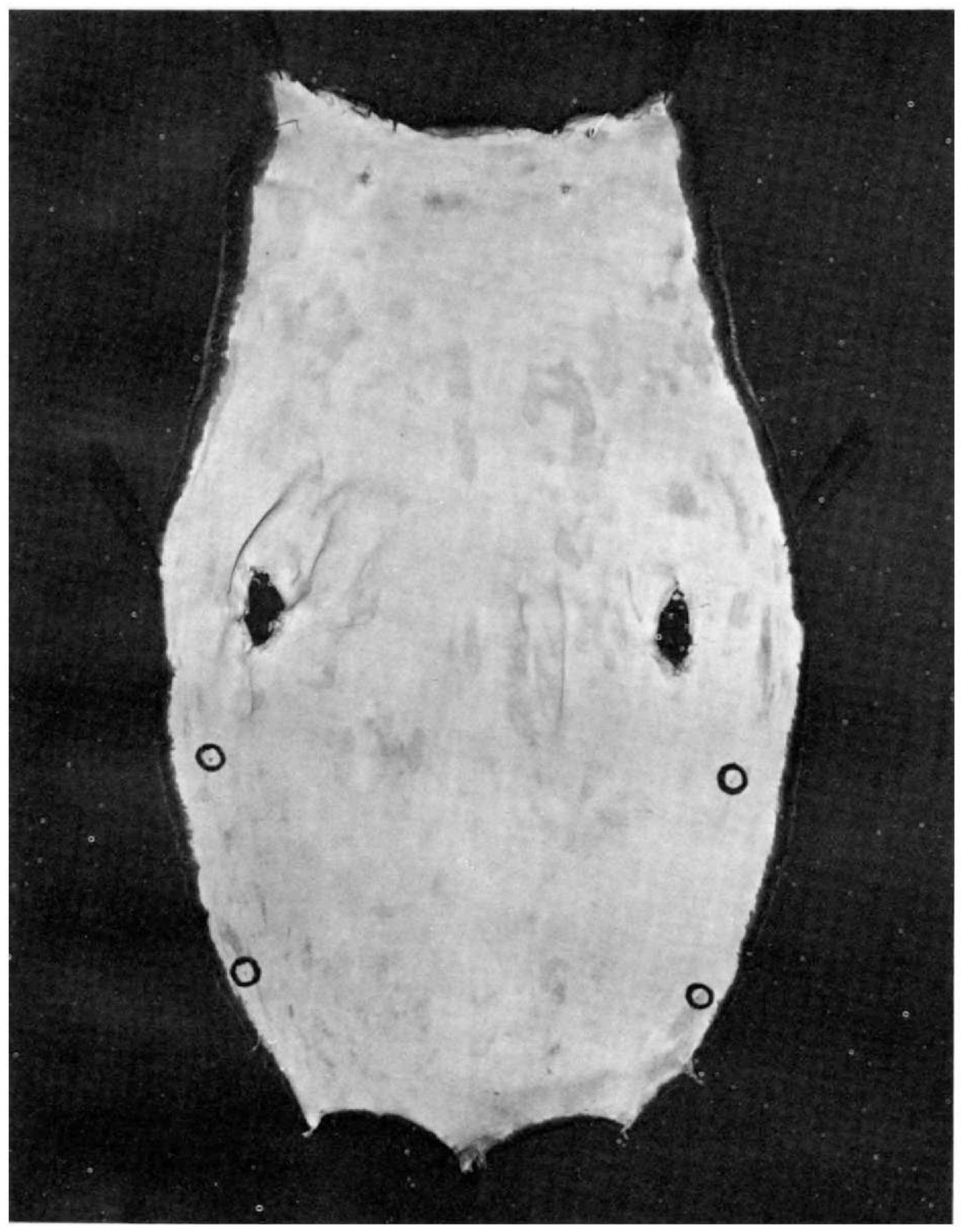

PLATE 105.-Leather side of tanned, buffed pelt of yearling male killed about 1 November, showing location of four rudimentary teats ; $\times 1 / 6 . \quad$ (4000 BDM 516) 

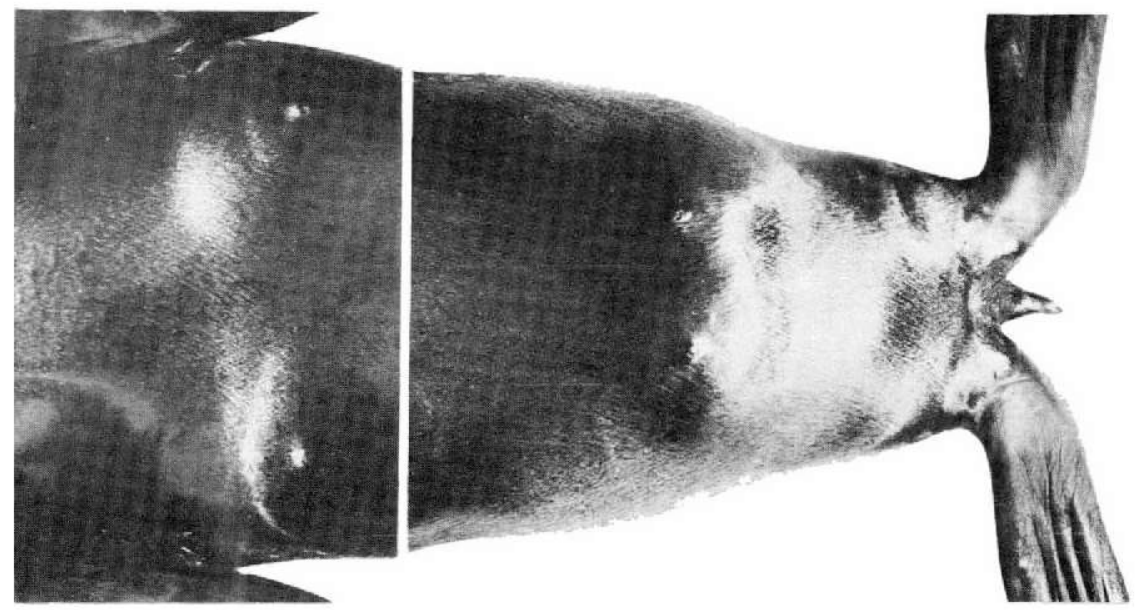

Plate 106-A.-Belly of adult female seal after $500 \mathrm{ml}$. embalming fluid has been injected in each teat.

(4025 and 4026)

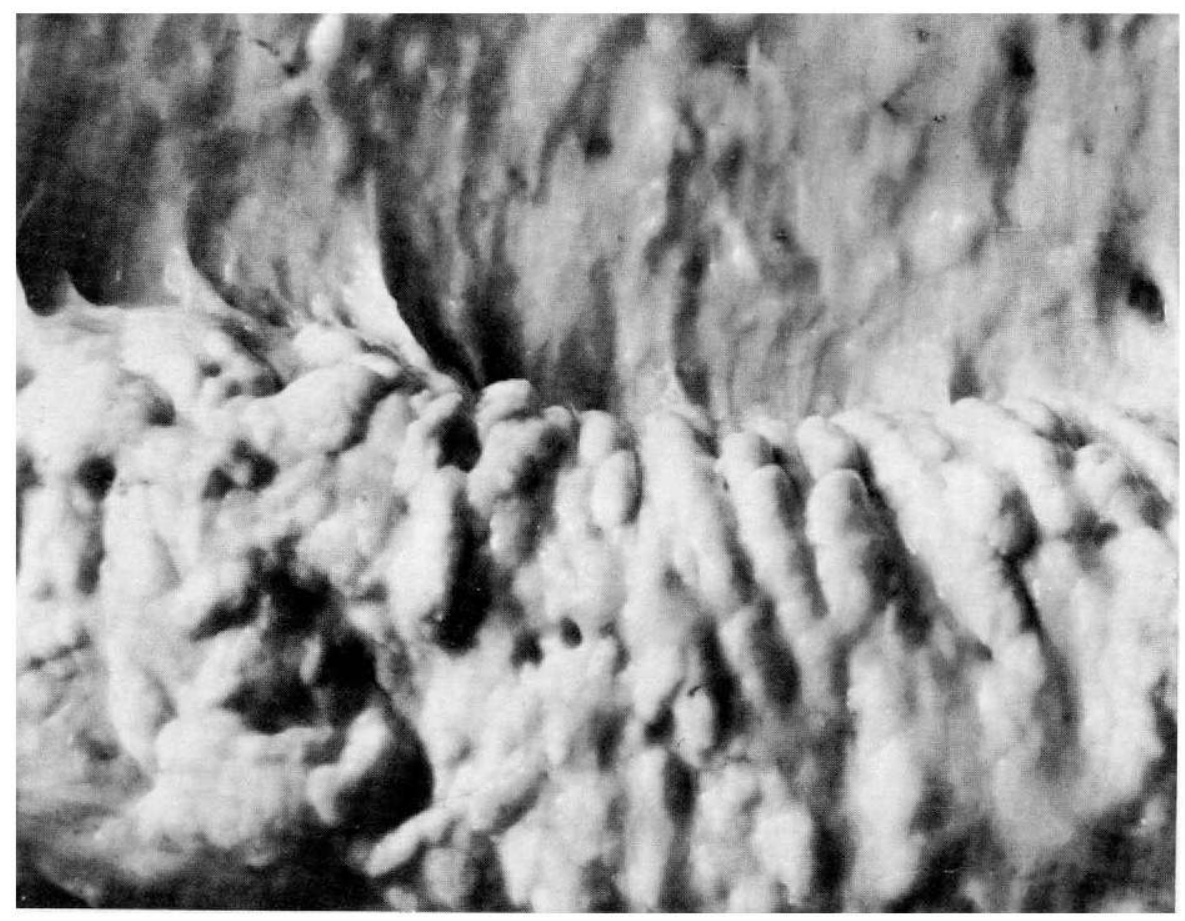

Plate 106-B,--Portion of mammary gland peeled down (by knife) from smooth tissue which connects it to body; $\times 3$.

(4034) 


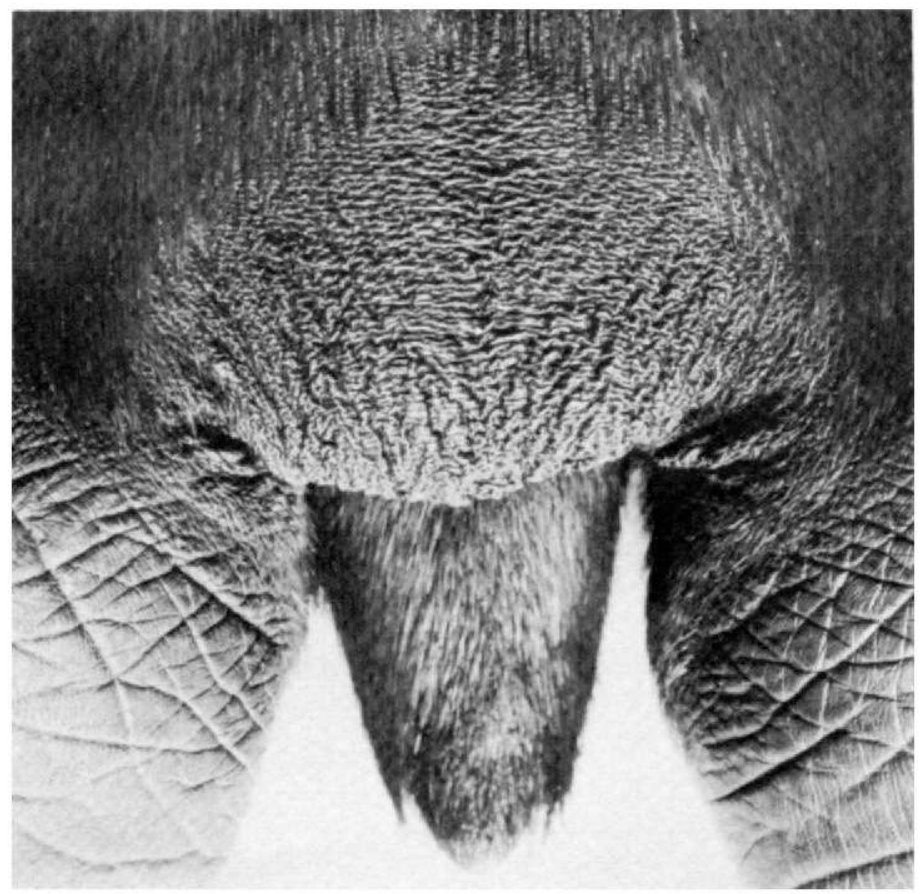

Plate 107-A.-Tail of 6-year-old male; scrotum relaxed; 9 September; natural size.

(4029)

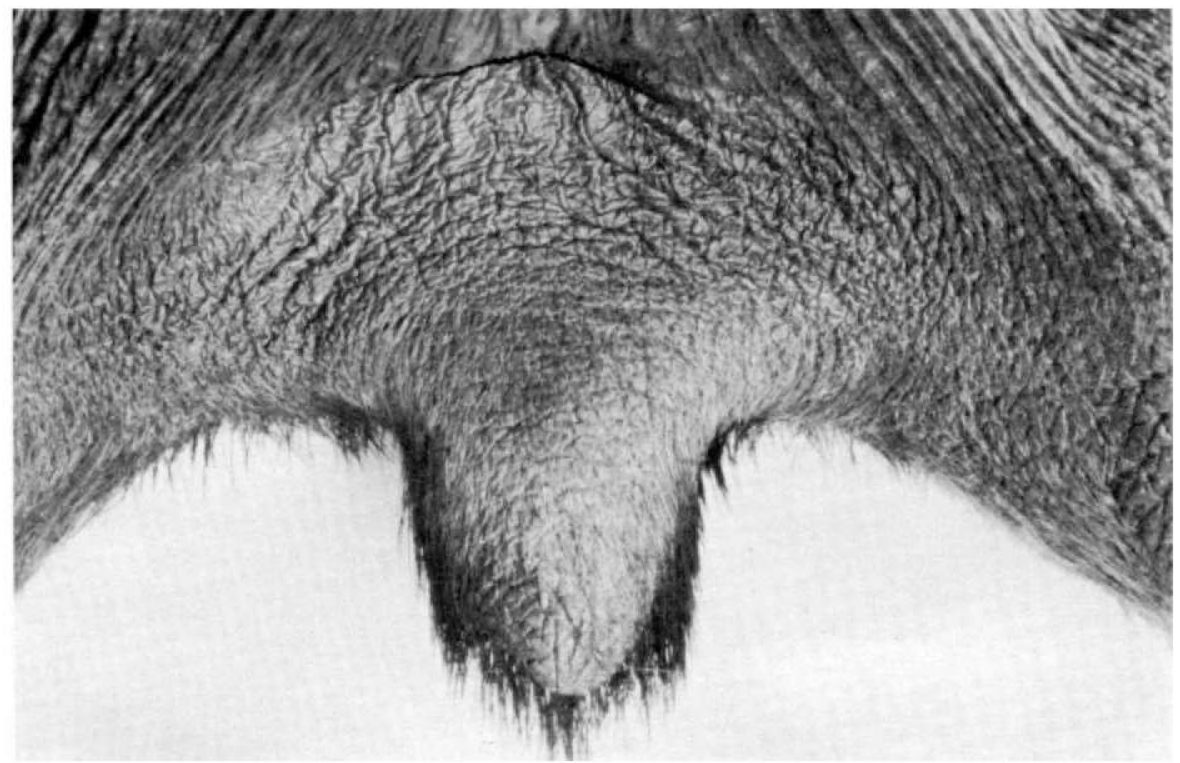

PLate 107-B.-Tail of old bull; scrotum pulled forward in order to reveal anus; 20 September; natural size. 


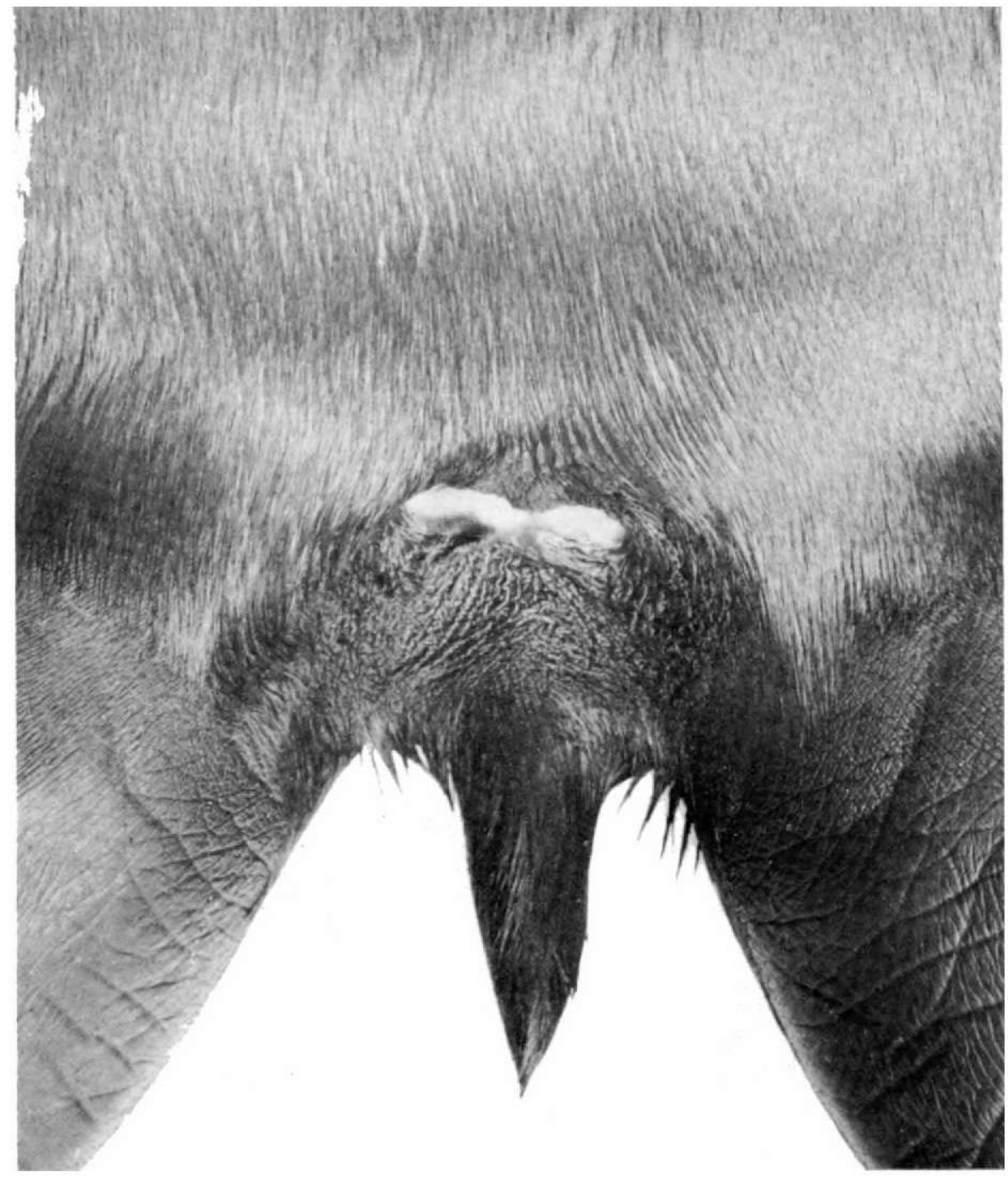

Plate 108.- Lower abdomen of female, weight $22.6 \mathrm{~kg}$. (50 lb.) ; probably nulliparous ; 4 August. Light-colored region is vestibule, with clitoris in front and anal opening behind and hidden.

(1898) 


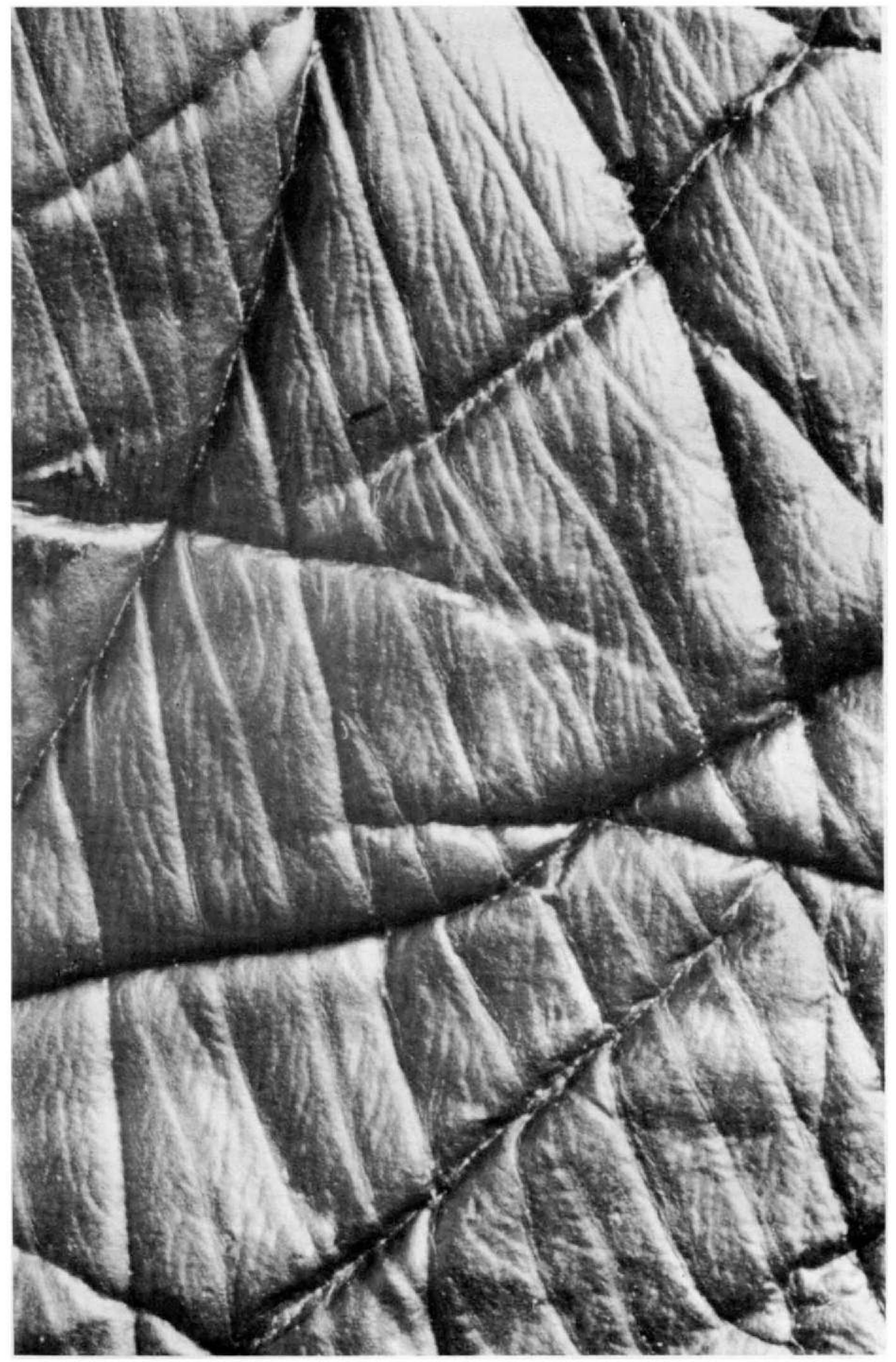

Plate 109.-Surface of right heel of silver pup; 28 September; $\times 10$.

(4065) 

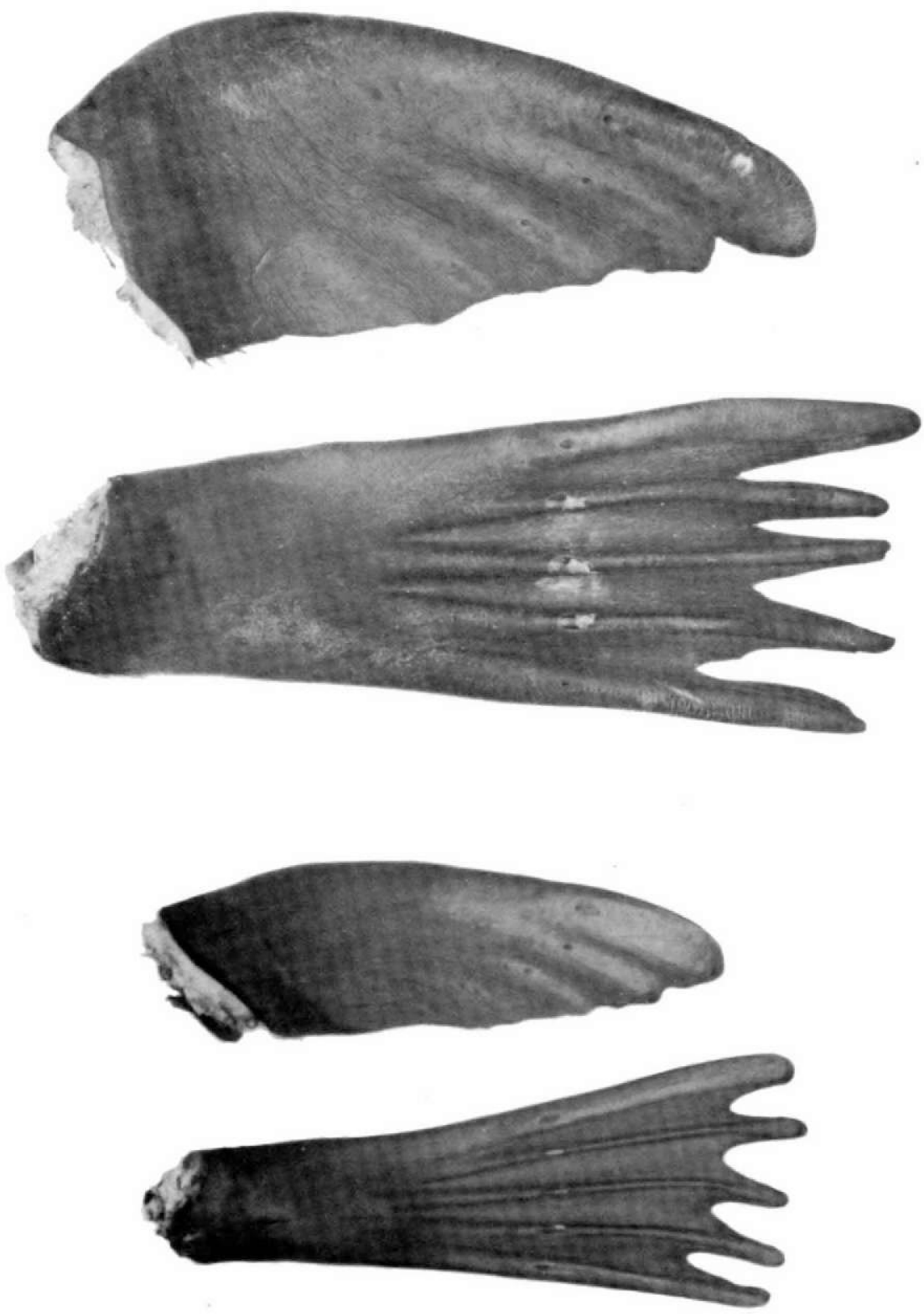

PLATE 110.-Right flippers of old male (above) and 7-year-old female (below) ; dorsal view ; $\times 0.18$.

(2413 and 2425) 


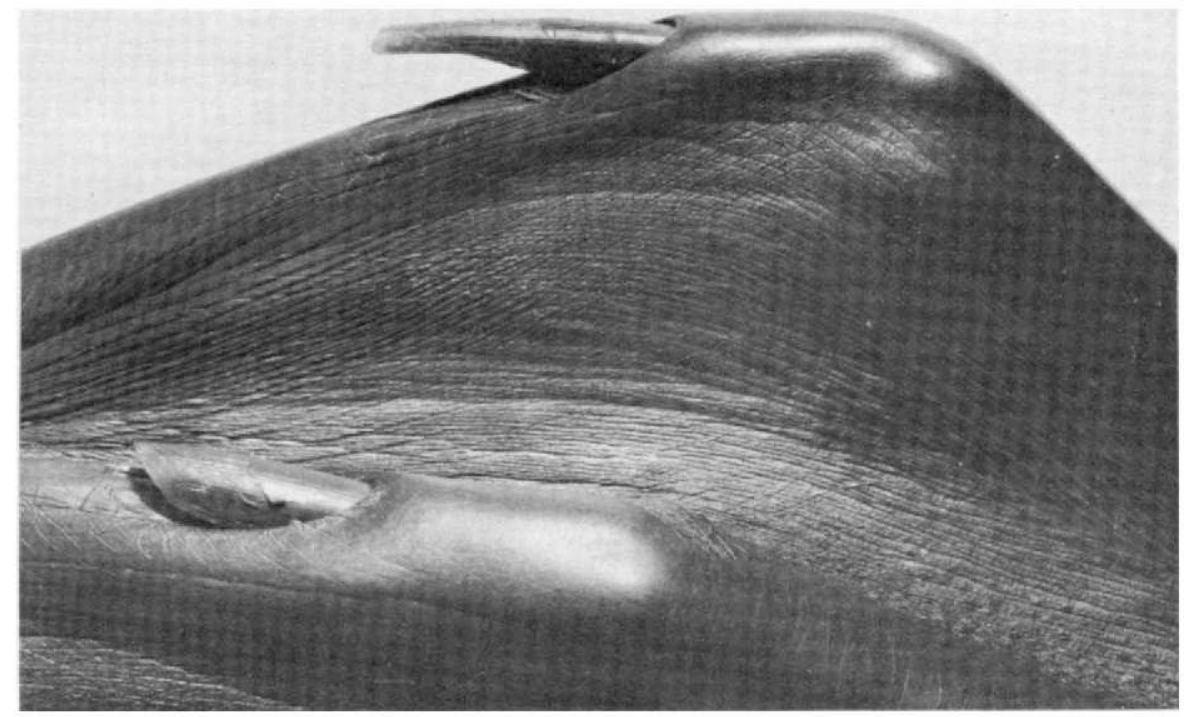

Plate 111-A.-Claws of 6-year-old male; digits 3 (in background) and 4 (in foreground) of left hind flipper; $\times 1.3$.

$(4030)$

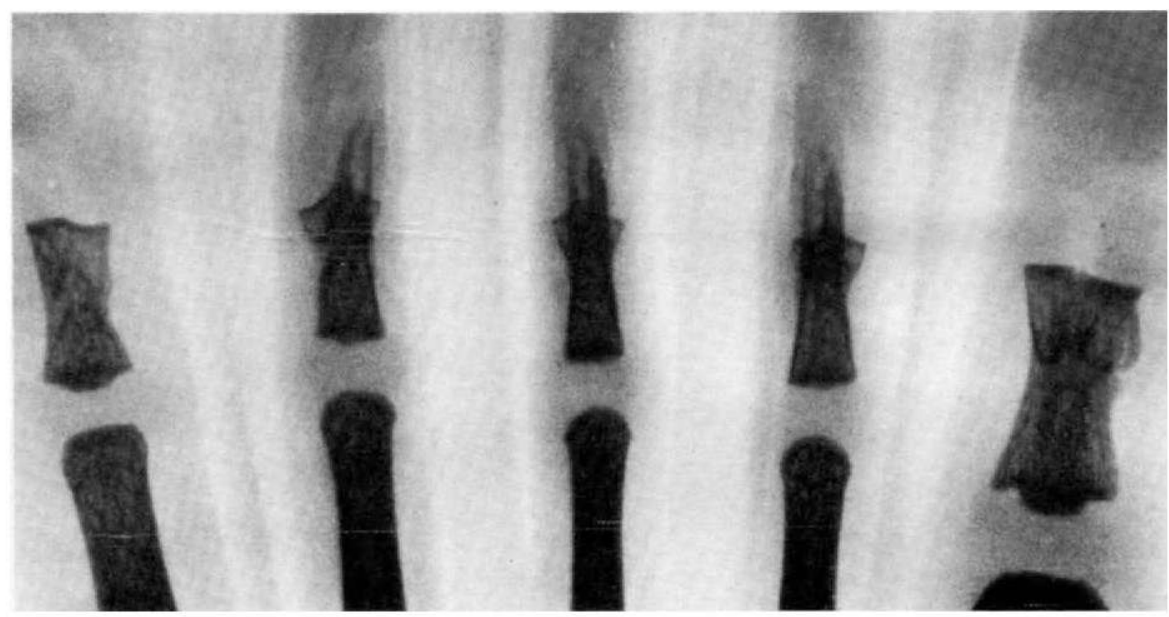

l'LATE 111-B.-Roentgenogram of hind flipper of 3-year-old male, showıng 3 functional claws; $\times 1.2$.

(4188) 


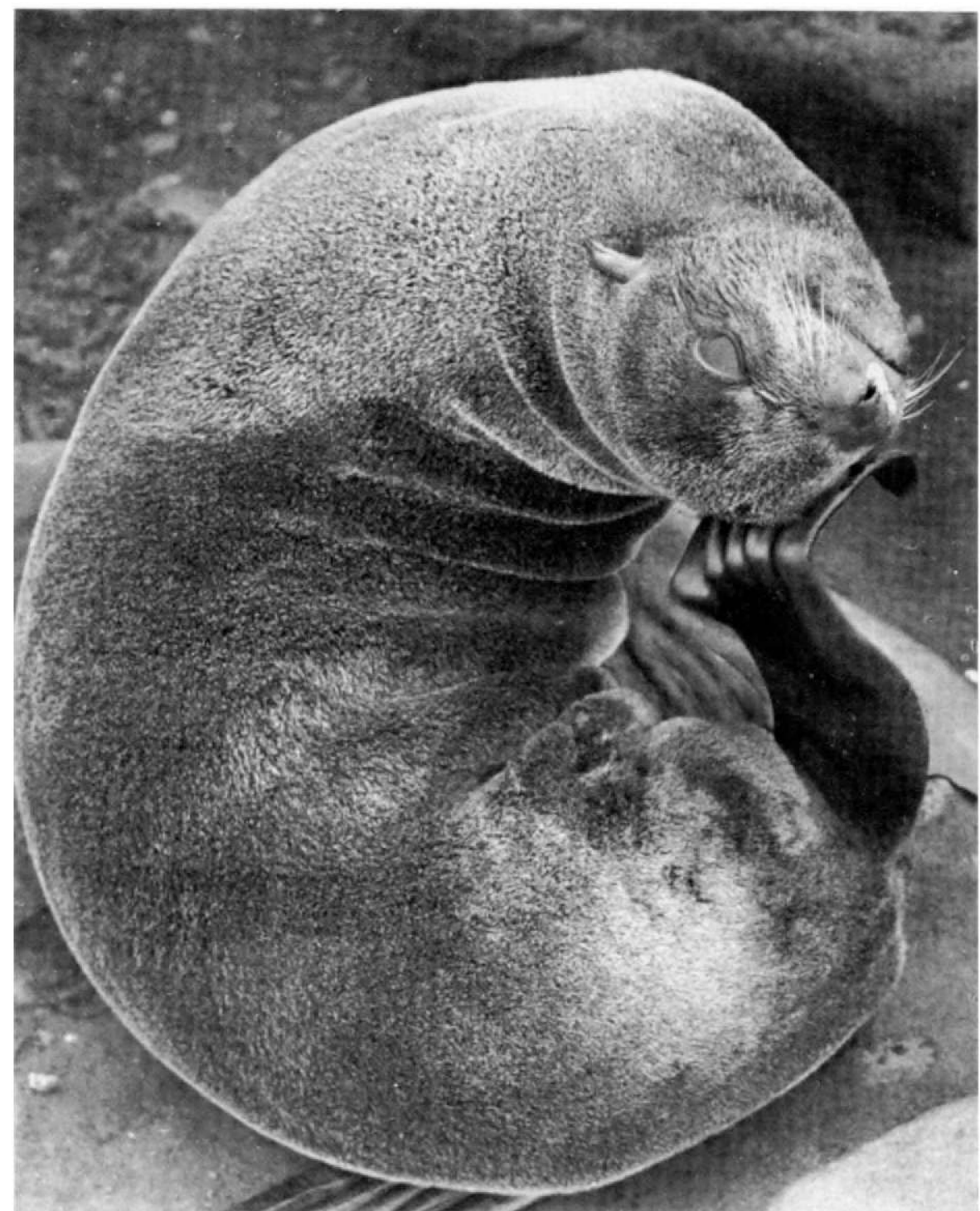

Plate 112.-Adult female scratching herself. Only the three middle claws of the hind flippers are functional. (4140 ex Karl W. Kenyon) 